\title{
AVALIAÇÃO DE FÉCULA E FARELO DE MANDIOCA COMO SUBSTRATOS PARA PRODUÇÃO DE CICLODEXTRINAS
}

\author{
ANDRÉA CURIACOS BERTOLINI \\ Engenheira Agrônoma
}

Orientadora: Prof ${ }^{\mathbf{a}}$. Drª . MARNEY PASCOLI CEREDA

Dissertação apresentada à Escola Superior de Agricultura "Luiz de Queiroz", da Universidade de São Paulo, para obtenção do título de Mestre em Ciências, Área de Concentração: Ciência e Tecnologia de Alimentos.

PIRACICABA

Estado de São Paulo - Brasil

Outubro de 1995 
Dados internacionais de Catalogação na Publicação (CIP) Divisão de Biblioteca e Documentação - CAMPUS "LUIZ DE QUEIROZ"/USP

Bertol ini, Andréa Curiacos

Avaliação de fécula e farelo de mandioca como substratos para produção de ciclodextrinas. Piracicaba, 1995.

130p. ilus.

Diss. (Mestre) - ESALQ

Bibliografia.

1. Ciclodextrina - Produção 2. Farelo de mandioca como substrato Avaliação 3. Fecula de mandioca como substrato - Avaliação

1. Escola Superior de Agricultura Luiz de Queiroz, Piracicaba 


\section{AVALIAÇÃO DE FÉCULA E FARELO DE MANDIOCA COMO SUBSTRATOS PARA PRODUÇÃO DE CICLODEXTRINAS}

Aprovada em 12 de dezembro de 1995

Comissão julgadora:

Prof ${ }^{\mathbf{a}}$. Dr ${ }^{\mathbf{a}}$. Marney Pascoli Cereda

F.C.A./UNESP/Botucatu

Prof ${ }^{\mathbf{a}}$. Dra ${ }^{\mathbf{a}}$. Marília Oetterer

ESALQ/USP/Piracicaba

Dr. Gerard Chuzel

CIRAD/SAS/Montpellier

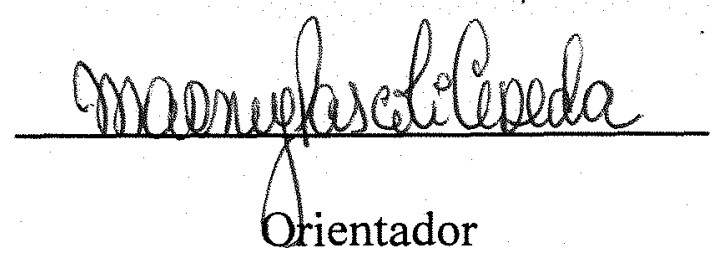




\section{AGRADECIMENTOS}

À CAPES, pela bolsa oferecida.

À Comunidade Econômica Européia, pelos equipamentos doados.

À Prof ${ }^{\mathbf{1}}$. Marney Pascoli Cereda, pela orientação e estímulo.

À Gerard Chuzel, da Cooperação Técnica Francesa, pelas sugestões.

Ao Prof. Cláudio Cabello, da UNESP-Bauru, pela amizade e sugestões.

Ao Prof. Lúcio Benedicto Kroll, do Departamento de Matemática Bioestatística, do Instituto de Biociências da UNESP - Botucatu, pelas sugestões na análise dos dados.

À Beatriz Helena Giongo, do Departamento de Ciência e Tecnologia de Alimentos, da ESALQ-USP, pela revisão das referências bibliografias.

Ao Claudir Benedito Siqueira, da Faculdade de Ciências Agronômicas da UNESPBotucatu, pela construção da prensa.

Aos técnicos Francisco Rossi, Luís Henrique Urbano, Marcelo Pozza Garcia e Edson Rosa, do Laboratório do Departamento de Tecnologia de Produto Agropecuários da Faculdade de Ciências Agronômicas, da UNESP-Botucatu, pelo auxílio nas análises.

Aos Profs. Paulo Rodolfo Leopoldo e Nelson Miguel Teixeira e ao técnico Silvio Sabatini Simoneti Scolastici, do Depto. de Engenharia Rural da Faculdade de Ciências Agronômicas - UNESP- Botucatu, pelo auxílio e atenção.

E a todos que contribuíram, de algum modo, para a realização deste trabalho. 


\section{SUMÁRIO}

LISTA DE FIGURAS vii

LISTA DE TABELAS ix

RESUMO $x$

SUMMARY xii

1.INTRODUÇÃO 1

2.REVISÃO BIBLIOGRÁFICA 3

2.1.O amido e sua estrutura 3

2.2.0 farelo como resíduo da indústria de mandioca 8

2.3. As ciclodextrinas 11

2.3.1.Histórico 11

2.3.2.Características físico-quimicas das CDs 11

2.3.3.CDs modificadas 16

2.3.3.1.CDs metiladas $\quad 16$

2.3.3.2.CDs ramificadas $\quad 18$

2.3.3.3.Polímeros de CDs 18

2.3.4.Degradação de CDs 19

2.3.5.Estudos de toxidez 26

2.3.6.Efeito das CDs no metabolismo 29

2.3.7.Aplicação industrial das CDs 30

2.3.7.1.Em alimentos $\quad 30$

2.3.7.2.Em fármacos $\quad 34$

2.3.7.3.Efeito sobre o crescimento microbiano 35

2.3.7.4.Outros 36

2.3.8.Mercado potencial $\quad 38$

2.4.Ciclodextrina glucanotransferase (CGTase) $\quad 40$

2.4.1.Características da CGTase $\quad 40$ 
2.4.2.Modo de ação 43

2.4.3.Aceptores da CGTase 46

2.4.4.Similaridades entre CGTases e amilases 50

2.4.5.Estrutura molecular das CGTases 53

2.4.6.Fontes produtoras de CGTase 57

2.4.7.Determinação da atividade da CGTase 60

2.4.8.Imobilização da CGTase 63

2.5.Substratos usados para produzir CDs 64

2.5.1.Matéria prima para produção de CDs 64

2.5.2. Influência da estrutura do substrato na produção de CDs 66

2.5.3.Concentração do substrato $\quad 67$

2.6.Produção de CDs $\quad 70$

2.6.1.Produção industrial das CDs $\quad 70$

2.6.2.Liquefação prévia do amido $\quad 72$

2.6.3.Uso de aditivos durante a produção de CDs 76

2.6.4.Purificação de CDs 79

2.7. Quantificação das CDs $\quad 80$

3. MATERIAL E MÉTODOS 86

3.1.Matéria prima $\quad 86$

3.2.Enzimas, reagentes e equipamentos $\quad 86$

3.2.1.Enzimas $\quad 86$

3.2.2.Reagentes $\quad 87$

3.2.3.Banhos termostáticos $\quad 87$

3.2.4.Prensagem e centrífugação das amostras $\quad 87$

3.2.5.Análises 88

3.3. Métodos 88

3.3.1.Padrões para HPLC $\quad 88$ 
3.3.2.Pré tratamentos do farelo $\quad 89$

3.3.3.Produção de CDs $\quad 89$

3.3.4.Preparo das amostras 90

3.3.5.Análises 90

3.3.5.1.Amido residual 90

$\begin{array}{ll}\text { 3.3.5.2. Extremidades redutoras } & 91\end{array}$

3.3.5.3.Ciclodextrinas 91

3.3.5.4.Análise estatística $\quad 91$

4.RESULTADOS E DISCUSSÃO 95

4.1. Caracterização dos substratos 95

4.2.Identificação dos padrões para HPI.C 96

4.3. Pré tratamentos do farelo 101

4.4.Produção de CDs 106

4.4.1.Produção de $\alpha$-CDs 106

$\begin{array}{ll}\text { 4.4.2.Produção de } \beta \text {-CDs } & 107\end{array}$

4.4.3. Comparação entre produção de CDs usando $\begin{array}{ll}\text { farelo e fécula como substratos } & 108\end{array}$

4.4.4. Extremidades redutoras 112

$\begin{array}{ll}\text { 4.4.5. Amido residual } & 114\end{array}$

5.CONCLUSÕES 119

6.REFERÊNCIAS BIBLIOGRÁFICAS 121

$\begin{array}{ll}\text { 7.APÊNDICES } & 137\end{array}$ 


\section{LISTA DE FIGURAS}

Figura 1. Homopolímeros de glicose. 4

Figura 2. Estrutura linear da cadeia de amilose. 5

Figura 3. Estrutura ramificada da cadeia de amilopectina. 5

$\begin{array}{ll}\text { Figura 4. Estrutura proposta por French para amilopectina. } & 6\end{array}$

Figura 5. Estrutura proposta por Mac GREGOR (1993) para o subsítio ativo de enzimas da família das $\alpha$-amilases.

Figura 6. Fluxograma da quantidade de resíduos produzidos durante o processamento de raízes de mandioca para obtenção da fécula. $\quad 10$

$\begin{array}{ll}\text { Figura 7. Representação esquemática da estrutura funcional das ciclodextrinas. } & 12\end{array}$

Figura 8. Formação de complexo através do encapsulamento de molécula de p-xileno por $\beta$-CD. 13

Figura 9. Estrutura de $\alpha, \beta$ e $\chi$-CDs. 13

Figura 10. Reações catalisadas pela CGTase. 44

$\begin{array}{ll}\text { Figura 11. Reação entre CDs e vários aceptores. } & 48\end{array}$

Figura 12. Modelo de ação das enzimas $\alpha$-amilases e CGTases e seus respectivos pontos de hidrólise. 52

Figura 13. Fluxograma referente à produção de CDs usando fécula como substrato. $\quad 92$

$\begin{array}{ll}\text { Figura 14. Fluxograma referente à produção de CDs usando farelo como substrato. } & 93\end{array}$

Figura 15.Peneira de cobre inserida no recipiente coletor de aço inoxidável. 94

Figura 16. Prensa usada para recuperar líquido da suspensão de farelo. 94

Figura 17. Cromatograma padrão de $\alpha, \beta$ e $\chi$-CDs. 97

$\begin{array}{ll}\text { Figura 18.Cromatograma padrão de maltose e glicose. } & 97\end{array}$

Figura 19. Cromatograma de hidrolisado de fécula de mandioca com $\alpha$-amilase 98

Figura 20. Cromatograma relativo à fécula de mandioca após hidrólise com CGTase. 99

Figura 21.Cromatograma referente à amilopectina hidrolisada com CGTase. 100

Figura 22. Cromatograma referente à amilose hidrolisada com CGTase. 100

Figura 23. Cromatograma referente ao farelo liquefeito $\operatorname{com} \alpha$-amilase, mostrando 
amido pouco hidrolisado e dextrinas de diferentes graus de polimerização (pontos a a f).

Figura 24. Cromatograma referente ao farelo liquefeito com celulase mostrando amido pouco hidrolisado e dextrinas de diferentes graus de polimerização (pontos a a c).

Figura 25. Cromatograma referente ao farelo liquefeito com CGTase.

Figura 26. Cromatograma do farelo liquefeito com celulase e incubado com CGTase durante 6 horas.

Figura 27. Cromatograma do farelo liquefeito $\operatorname{com} \alpha$-amilase e incubado com CGTase durante 6 horas.

Figura 28. Cromatograma do farelo liquefeito $\operatorname{com} \alpha$-amilase e tratado $\operatorname{com} \beta$-amilase após a reação com CGTase.

Figura 29. Cromatograma do farelo liquefeito com celulase e tratado com $\beta$-amilase após reação com CGTase.

Figura 30. Cromatograma do farelo liquefeito com CGTase e tratado com $\beta$-amilase após reação com CGTase.

Figura 31. Produção de $\alpha$ e $\beta$-CDs durante 24 horas, usando fécula e farelo como substratos.

Figura 32. Perfil do hidrolisado de farelo após 24 horas de reação com CGTase.

Figura 33. Perfil do hidrolisado de fécula após 24 horas de reação com CGTase, com dextrinas de diferentes grau de polimerização (pontos a a d).

Figura 34. Perfil do hidrolisado de fécula, após 24 horas de reação com CGTase quando submetidas à ação de $\beta$-amilase

Figura 35. Perfil do hidrolisado do farelo, após 24 horas de reação com CGTase quando submetidas à ação de $\beta$-amilase

Figura 36. Comparação entre a produção de extremidade redutora ao longo de 24 horas na reação com CGTase, usando fécula e farelo como substratos.

Figura 37. Amido não hidrolisado pela CGTase ao longo de 24 horas de reação, usando fécula e farelo como substratos. 


\section{LISTA DE TABELAS}

Tabela 1. Valores médios de determinações de farelos originários de indústrias de São Paulo, Minas Gerais e Paraná. 9

$\begin{array}{ll}\text { Tabela 2. Propriedades fìsicas da ciclodextrinas. } & 14\end{array}$

$\begin{array}{ll}\text { Tabela 3. Fatores de solubilidade de diferentes CDs modificadas. } & 17\end{array}$

Tabela 4. Algumas enzimas que degradam CDs. 23

Tabela 5. Comparação entre substratos específicos de CDases de diferentes fontes. $\quad 26$

Tabela 6. Principais países produtores de CDs, suas indústrias e produtos. 39

Tabela 7. Comparação entre a atividade das CGTase quiméricas 17-1 e 38-2, construídas por KANEKO et al. (1990 a). 55

Tabela 8. Proporções de CDs produzidas pelas CGTases de diferentes $\begin{array}{ll}\text { microorganismos. } & 60\end{array}$

Tabela 9. Efeito do pH na liquefação do amido.

Tabela 10.Diferentes metodologias para determinação de CDs, usando HPLC. 83

Tabela 11. Caracterização dos substratos usados para produção de CDs. 95

Tabela 12. Comparação da produção de CDs, extremidades redutoras e amido residual. Médias dos diferentes tempos de reação (tratamentos das subparcelas) através do Teste de Tuckey $(\alpha=0,05)$.

Tabela 13. Comparação entre substratos fécula e farelo na produção de CDs. Médias finais dos tratamentos das parcelas Fécula e Farelo para comparações pelo Teste de Tuckey $(\alpha=0,05)$.

Tabela 14.Valor da produção de CDs, extremidades redutoras e amido residual a partir substratos de fécula e farelo. Médias das três repetições de análises feitas em amostras de reações ao longo de 24 horas.

Tabela 15. Estudo da correlação entre as médias das variáveis analisadas. 


\title{
AVALIAÇÃO DE FÉCULA E FARELO DE MANDIOCA COMO SUBSTRATOS PARA PRODUÇÃO DE CICLODEXTRINAS
}

\author{
Autora: Andréa Curiacos Bertolini \\ Orientadora: Prof. Dr. Marney Pascoli Cereda
}

\section{RESUMO}

Ciclodextrinas (CDs) são oligossacarídeos cíclicos que apresentam a capacidade de formar complexos de inclusão com outras moléculas, modificando suas características. Por tal razão, as CDs apresentam grande interesse para a indústria alimentícia e farmacêutica, sendo que seu custo de produção é o principal fator limitante de sua utilização. As fecularias, indústrias que extraem fécula de mandioca, estão distribuídas por todo o país, sendo o farelo um resíduo que possui teor de amido próximo entre 70 e $80 \%$. Neste trabalho, verificou-se a viabilidade de produzir CDs usando fécula e farelo de mandioca como substratos. A produção de CDs foi feita usando a enzima ciclodexirina glucosiltransferase (CGTase E. C. 2.4.1.19), proveniente de Bacillus macerans, da Amano International Enzyme, a $50^{\circ} \mathrm{C}$ e a avaliação dos resultados foi feito através de HPLC (High Performance Chromatography Liquid). Os resultados revelaram que a produção de CDs a partir de tais substratos é viável. No caso do farelo, houve necessidade de realizar prensagem para recuperar a fase líquida onde estavam presentes as CDs. A fécula de mandioca resultou em maior produção de $\beta-C D$ que o farelo, não havendo diferença significativa entre para os dois substratos em relação a produção de $\alpha-C D$. $O$ farelo propiciou maior proporção de $\alpha: \beta-C D$ s equivalente a $1,5: 1,0$; enquanto para a fécula a proporção foi de 1,0:1,45. Ensaios de liquefação prévia do amido com as enzimas ciclodextrina glucanotransferase (CGTase), celulase e $\alpha$-amilase não proporcionaram diferença na produção de CDs. Após 4 horas de reação houve tendência à estabilização da produção de CDs, de extremidades redutoras e de hidrólise de amido, indicando 
considerável perda da atividade enzimática. Para condições de ensaio, pode-se considerar que 4 horas de reação são suficientes para que a conversão de amido em $\alpha$-CDs seja de $19 \%$ para a fécula e $27 \%$ para o farelo. Para $\beta$-CDs, os valores foram de $21 \%$ para fécula e $15 \%$ para o farelo. Tais resultados indicam que o farelo pode ser um promissor substrato para a produção de CDs. 


\title{
CASSAVA STARCH AND CASSAVA BRAN ASSAY AS SUBSTRATES FOR CYCLODEXTRINS PRODUCTION
}

\author{
Author: Andréa Curiacos Bertolini \\ Adviser: Prof. Dr. Marney Pascoli Cereda
}

\section{SUMMARY}

Cyclodextrins (CDs) are cyclic and non reducing oligosaccharids with the ability to form complexes with a wide range of hydrophobic molecules used in food, cosmetic and pharmaceutical industries. Their manufacturing is very expensive. The cassava industrialization produces as waste the bran, with a high starch content. In this work, CDs were produced by using cassava starch and cassava bran using cyclodextrin glucosiltransferase (CGTase E. C. 2.4.1.19), from Bacillus macerans, (Amano International Enzyme), $50^{\circ} \mathrm{C}$. The production was evaluated by HPLC (High Performance Liquid Chromatography). The production rate was not affected by using previous liquefaction with cellulase, CGTase, or $\alpha$-amylase. The production rate of $\alpha: \beta$ CD with bran was 1.5:1.0 and with starch was 1.0:1.45. There were not difference of $\alpha-$ $\mathrm{CD}$ production between two treatments, but the $\beta-\mathrm{CD}$ production rate was higher with cassava starch relatively to bran. After four hours of reaction, there was a considerable loss of enzyme activity, and the $\alpha-\mathrm{CD}$ conversion with starch was $19 \%$ and with bran, $27 \%$. Beta-CD conversion was $21 \%$ with starch and $15 \%$ with bran. 


\section{INTRODUÇÃO}

Ciclodextrinas (CDs) são oligossacarídeos cíclicos, não redutores, compostos de seis, sete ou oito unidades de glucose unidas por ligações tipo $\alpha-1,4$, denominadas respectivamente de $\alpha, \beta$ e $\chi$-CD. Devido à sua estrutura em forma de anel, são capazes de formar complexos de inclusão através de sua cavidade hidrofóbica com vários compostos orgânicos ou não, modificando as características químicas e físicas dos mesmos. Tal característica é denominada de "encapsulação molecular". Devido à suas propriedades, as CDs apresentam-se como agentes de grande interesse nas técnicas mais modernas de microencapsulação, que é definido como a tecnologia de "empacotar" moléculas de sólido, líquido ou gás, que serão liberadas sob condições pré-determinadas. Proteção contra oxidação, contra degradação pela luz, pelo calor, perdas por volatilidade, redução ou eliminação de g ostos ou odores desagradáveis, estabilização de drogas, de cores, de vitaminas, de "flavors", ou de emulsões, aumento de solubilidade de produtos fármacos e alteração de características químicas são alguns dos efeitos causados pela encapsulação de compostos por CDs. Sua aplicação na indústria de alimentos e farmacêutica é cada vez maior. $\mathrm{O}$ crescente número de patentes sobre o assunto nos últimos 20 anos, reflete o interesse da indústria, salientando seu potencial econômico. CDs têm sido empregadas na Hungria e Japão desde 1970. Bélgica, França, Holanda, Itália, Luxemburgo, Espanha e Alemanha são países que têm o uso de CDs aprovado em alimentos. Nos EUA, CDs começaram a ser produzidas recentemente. No Japão, o maior produtor de CDs, cerca de $70 \%$ da produção é destinada à indústria alimentícia, sendo o restante usado em fármacos.

Até o presente momento o principal problema que limita sua utilização industrial é o alto custo de produção, superior ao dos amidos modificados. Em 1990, o total de CDs da produção mundial foi estimado em 850 toneladas anuais. Só nos EUA, o mercado potencial de CDs movimentaria 32.000 toneladas por ano; ou seja, o equivalente a U\$245 milhões. Em 1990, a $\beta$-CD estava cotada entre U\$15-20/ kg, no 
Japão e Europa. Para que as CDs conquistem o mercado, o preço da $\beta$-CD deve baixar à $\mathrm{U} \$ 5 / \mathrm{kg}$, devendo também ocorrer aumento de produtividade de $\alpha$ e $\chi$-CDs.

Aumento de atividade enzimática, otimização das condições de reação, novos métodos de recuperação e purificação têm sido os meios mais estudados para se aumentar a produção de CDs. Trabalhos visando a minimização dos custos de substratos porém são escassos. A matéria prima normalmente empregada na produção de CDs é o amido de batata e a produção é feita por batelada.

A indústria de mandioca está distribuída por todo país, variando quanto ao tamanho, onde as menores unidades processam em média uma tonelada de raízes por dia, enquanto as de médio e grande porte chegam a processar mais de 400 toneladas por dia. O farelo, juntamente com cascas, descarte e a crueira, está entre os resíduos sólidos gerados por estas indústrias. $\mathrm{O}$ farelo é gerado na etapa de extração da fécula e apresenta teor de fibras em tomo de $15 \%$ e fécula próximos a $70 \%$. O farelo é composto pelo material fibroso da raiz, contendo parte da fécula que não foi extraída durante o processo e, por embeber-se de água, apresenta muitos vezes peso maior que a própria matériaprima, com cerca de $75 \%$ de umidade. Sua composição varia em função da tecnologia de extração adotada (CEREDA, 1994). A produção de fécula no Brasil é de 300.000 toneladas/ano, estimando-se a de farelo em cerca de 50.400 toneladas/ano (GRIFFON et al., 1995), sendo o preço da fécula cotado entre U\$200-400/tonelada. Há muitas propostas para aproveitar o farelo, mas a alimentação animal é a mais comum. A hidrólise do farelo através de amilases e celulases poderá propiciar a obtenção de produtos de valores agregados.

Esse trabalho tem por objetivo estabelecer a viabilidade da produção de CDs usando fécula e farelo de mandioca como matéria prima, bem como esclarecer alguns aspectos relativos à hidrólise destes materiais. 


\section{REVISÃO BIBLIOGRÁFICA}

\subsection{O amido e sua estrutura}

De acordo com a legislação do Brasil, amido é o carboidrato proveniente de grãos, enquanto fécula é proveniente de raízes e tubérculos. Na maioria dos países esta distinção não é considerada, mas há diferenças entre fécula e amido quanto às propriedades funcionais. Dentre os vegetais fontes de amido destacam-se o milho, batata, mandioca, arroz, trigo, milho "waxy", batata doce, araruta e sorgo (VAN BEYNUM e ROELS, 1985). As variedades de milho mais usadas são dentado e ceroso, além de variedades de milho com alto teor de amilose. A raiz da mandioca vem sendo usada em menor escala que o milho porém apresenta crescente importância na indústria alimentícia como substrato para produção de amido modificado (GALLIARD, 1987).

As moléculas de amido são depositadas em camadas sucessivas em tomo de um hilo central sob a forma de um grânulo firmemente empacotado. Essas camadas são unidas por pontes de hidrogênio (GALLIARD, 1987).

Quando o grânulo é aquecido na presença de água, as ligações de hidrogênio presentes nas áreas amorfas são rompidas, permitindo o intumescimento do grânulo. As ligações fortes da área cristalina possibilitam que o grânulo permaneça intacto até que estas se rompam em algum ponto (GALLIARD, 1987). Durante o intumescimento, a amilose tende a solubilizar-se e perde água para o meio aquoso na qual está imersa, iniciando assim o processo de gelatinização. Após algum tempo há uma tentativa de restruturação das pontes de hidrogênio, tomando a pasta opaca e com consistência semelhante à borracha. Esse processo é comumente denominado de retrogradação ou "setback". Devido à sua configuração, amilopectina apresenta menor tendência à retrogradação (GALLIARD, 1987).

Grânulos de amido diferem quanto à forma e tamanho de acordo com a planta de origem. O vegetal de origem do amido pode ser identificado através da observação dos grânulos com corantes como iodo ou por microscopia de varredura. Amidos tratados com 
soluções diluídas de iodo apresentam coloração azul quando há alto teor de amilose ou coloração vermelha, no caso de haver grande quantidade de amilopectina.

Grânulos de amido provenientes de milho podem apresentar formato anguloso ou arredondado. Já grânulos oriundos de batata são grandes e com formato oval. Amido de trigo apresenta uma mistura de grânulos grandes e pequenos. Grânulos com formato de sino ou truncados são característicos de mandioca. Amido de arroz é composto de grânulos muito pequenos e angulosos (VAN BEYNUM e ROELS, 1985).

Moléculas de amido são homopolímeros de unidades de anidroglucose (Fig.1.), podendo se apresentar em cadeias lineares ou ramificadas. Através da condensação enzimática que ocorre na planta, duas moléculas de glicose são unidas, geralmente através do carbono 1 e 4 e, ocasionalmente através do carbono 1 e 6 (BANKS e GREENWOOD, 1975).

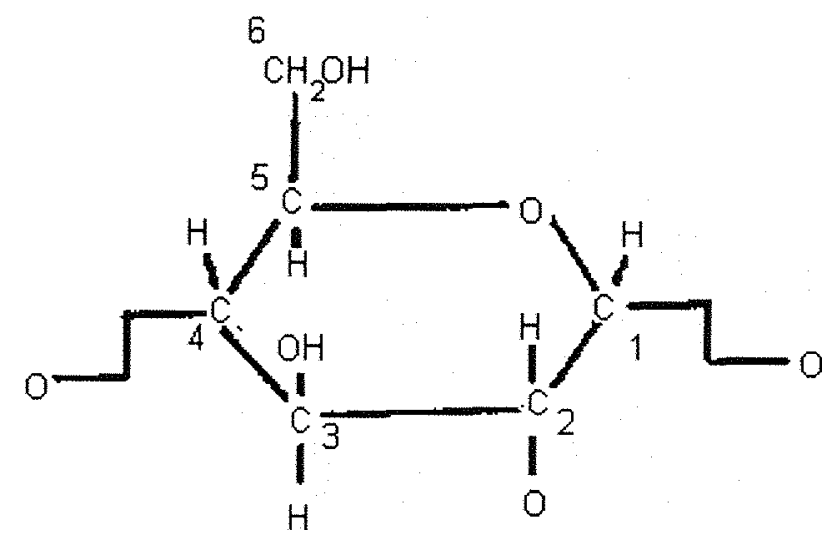

Fonte: WURZUBURG (1987)

Figura 1. Homopolímeros de glicose.

Quando há apenas ligações 1,4 o resultado é a formação do homopolímero de cadeia linear, chamado de amilose (Fig. 2.). O tamanho desta cadeia varia de acordo com a origem botânica do amido, mas geralmente oscila entre 500 e 2.000 unidades de glicose. Quando ocorrem ligações entre os carbonos 1 e 6 (Fig. 3), essas pequenas cadeias se unem à cadeia linear, originando ramificações. Esse tipo de molécula, apesar de ser muito maior 
que a molécula de amilose, possui cerca de 20 a 26 unidades de glicose na cadeia linear e é denominada amilopectina. A amilopectina apresenta diâmetro de 100 a $150 \AA$, com alto peso molecular (GALLIARD, 1987).

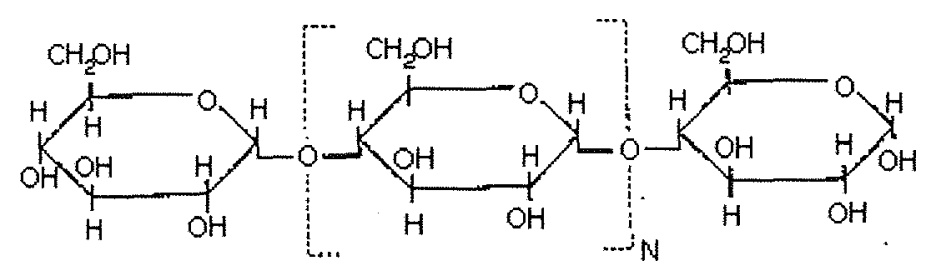

Fonte: VAN BEYNUM e ROELS (1985)

Figura 2. Estrutura linear da cadeia de amilose.

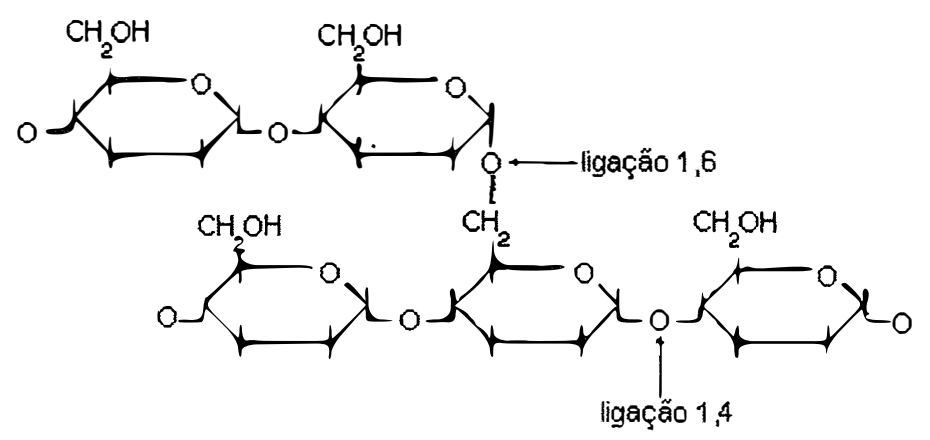

Fonte: VAN BEYNUM e ROELS (1985)

Figura 3. Estrutura ramificada da cadeia de amilopectina.

BENDER (1989) observou que os fragmentos de dextrinas $\beta$-limites de amilopectina de milho, mandioca e batata apresentaram grandes similaridades, indicando que as amilopectinas possuem semelhança estrutural entre si. Este autor estudando a estrutura de amilopectina, concluiu que há relações estruturais entre amilopectina de mandioca e de milho. Segundo BENDER (1981 b), tanto as cadeias tipo A como as tipo B, no modelo estrutural de amilopectina proposto por FRENCH (1973), podem sofrer ciclização e desproporcionalização. As cadeias tipo B estariam 
ligadas à cadeia central (tipo C), a qual possui a extremidade redutora. Ligadas as cadeias tipo B poderiam estar tanto cadeias tipo A como tipo B (Figura 4). A proporção de cadeias A/B, está entre 4:9 e 9:1 (WURZUBURG, 1987). A reação inicial de hidrólise observada nas cadeias de amilose também ocorre nas cadeias de amilopectina. Após a desramificação, os fragmentos das cadeias tipo B parecem se constituir em substrato preferencial da CGTase durante a reação de hidrólise (BENDER et al., 1982).

BENDER (1989) afirma que a degradação completa dos polissacarídeos é lenta e que depende do tamanho das ramificações das cadeias, onde cadeias mais curtas possuem taxas de degradações menores.

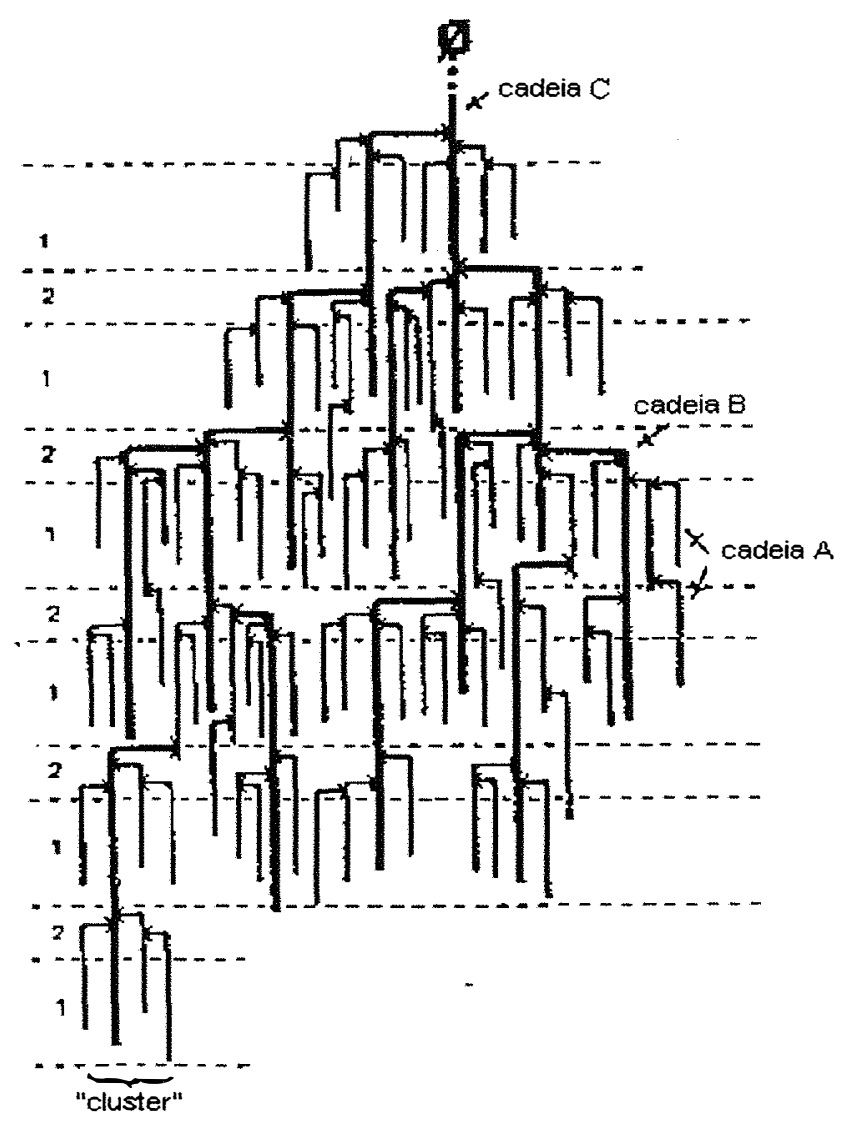

Fonte: WURZUBURG (1987)

Figura 4. Estrutura proposta por French para amilopectina: 1- cristalina; 2- amorfa; $\phi$ extremidade redutora. 
A proporção de amilose/amilopectina varia de acordo com a fonte da qual é obtida o amido. No amido de milho, cerca de $28 \%$ das moléculas são amilose, sendo que as variedades comerciais com alta quantidade de amilose possuem de 55 a $70 \%$ dessa molécula. Amido proveniente de mandioca apresenta grande quantidade de amilopectina, com cerca de $17 \%$ de amilose. Já as variedades de milho ceroso praticamente não possuem amilose (GALLIARD, 1987).

Enzimas que degradam amido são denominadas amilases. As amilases se dividem em:

- endo-amilases, que hidrolisam cadeias glucosídicas em qualquer ponto ou ligações específicas.

- exo-amilases, que hidrolisam a cadeia de amido a partir da extremidade redutora (Fig. 5).

As enzimas desramificantes são aquelas que hidrolisam as ligações tipo $\alpha-1,6$. Pululanase e isomerase são exemplos de enzimas desramificantes.

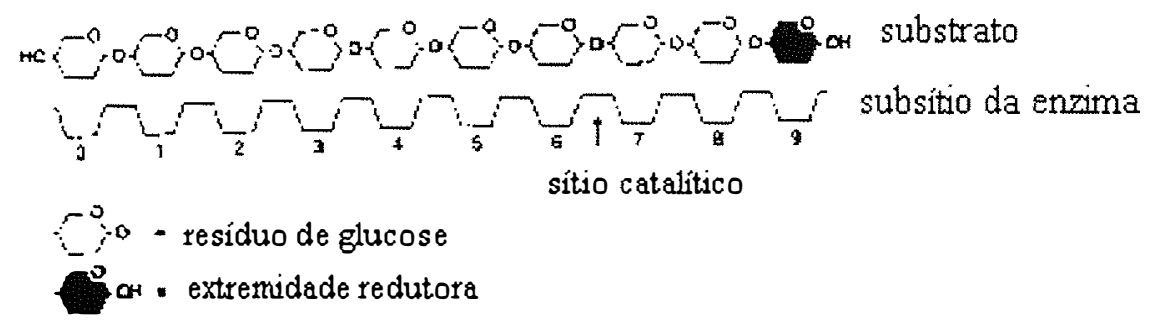

Fonte: Mac GREGOR (1993)

Figura 5. Estrutura proposta por Mac GREGOR (1993) para o subsítio ativo de enzimas da família das $\alpha$-amilases. Cada subsítio atuaria em uma molécula de glicose do substrato. 


\subsection{Farelo como resíduo da industrialização da mandioca}

Após um período de estagnação, que foi de 1987 a 1993, o setor de agroindústrias de extração de fécula de mandioca apresentou aumento crescente, sendo a produção nacional para 1995 estimada em 350.000 de toneladas de fécula de mandioca. A industrialização da mandioca está distribuída por todo país, variando quanto à capacidade, as menores unidades processando em média 1 tonelada de raízes por dia, enquanto as de médio e grande porte chegam a processar mais de 400 toneladas por dia. As indústrias alimentícias são os principais compradores de fécula chegando a representar $44 \%$ do consumo em algumas regiões, seguidas pelos frigoríficos, pelas indústrias farmacêuticas, de papel e celulose, química e têxtil. A desorganização das fecularias resulta em grande variação do preço da fécula de mandioca, o qual oscila entre US\$ 200 e 400/tonelada (VILPOUX e CEREDA, 1995).

Segundo ALFA LAVAL (1972), para cada $25 \mathrm{~kg}$ de fécula extraída são produzidos $6,4 \mathrm{~kg}$ de farelo, sendo que $4,5 \mathrm{~kg}$ são de fécula não extraída (Fig. 6). A tabela a seguir fornece os valores médios da composição do farelo em vários estados do Brasil. 
Tabela 1. Valores médios dos componentes de farelos originários de indústrias de São Paulo, Minas Gerais e Paraná.

\begin{tabular}{c|ccc}
\hline & São Paulo & Minas Gerais & Paraná \\
\hline Umidade (\%) & 9,42 & 14,82 & 9,52 \\
& & & \\
\hline Expresso em g/100g de matéria seca & & & 0,66 \\
\hline Cinzas & 0,83 & 3,77 & - \\
Carboidratos solúveis & 0,01 & - & 63,85 \\
Amido & 69,76 & 74,99 & 0,83 \\
Lipídeos & 0,65 & 0,28 & 0,32 \\
Nitrogênio & 0,24 & 1,86 & 14,88 \\
Fibra & 11,08 & 7,81 & - \\
\hline Expresso em ppm de matéria seca & & & - \\
\hline Cianeto total & 0 & 0 & - \\
Fósforo & - & 30 & - \\
Potássio & - & 280 & \\
Cálcio & - & 90 & \\
\hline
\end{tabular}

Fonte: CEREDA (1994)

A consciência de que o desenvolvimento industrial está ligado ao meio ambiente de modo que é impossível desenvolver um em detrimento do outro, foi o enfoque do final do século XX. Levando em consideração que é mais fácil justificar o tratamento de resíduos quando esses passam a ser subprodutos passíveis de comercialização, torna-se importante o desenvolvimento de pesquisas que enfoquem novas formas de utilização e transformação desses subprodutos, aumentando assim seu valor agregado (CEREDA, 1994). 


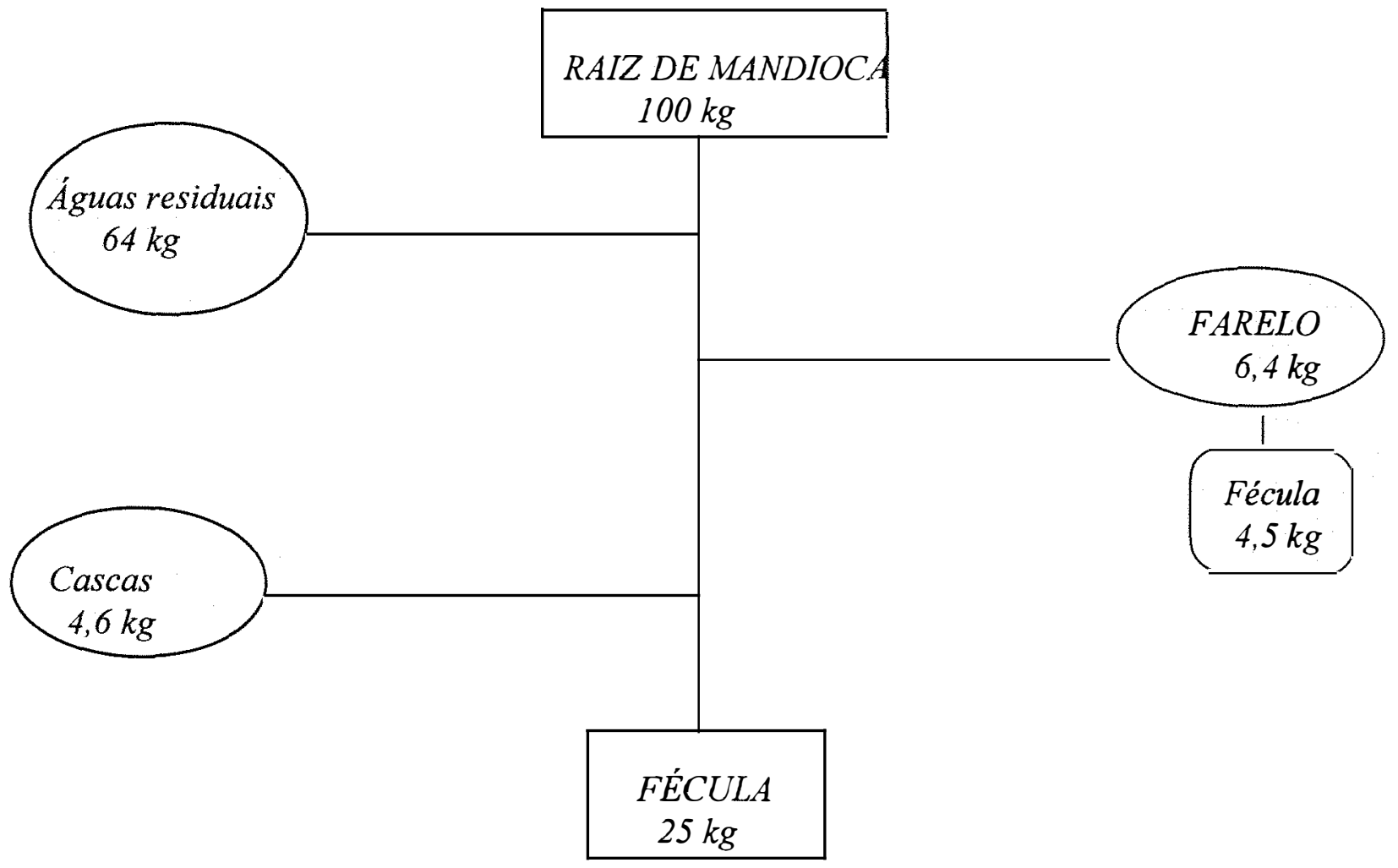

Fonte: ALFA LAVAL (1972).

Figura 6. Fluxograma da quantidade de resíduos produzidos durante o processamento de raízes de mandioca para obtenção da fécula. Cálculos feitos com umidade de $12 \%$.

Diversos trabalhos de pesquisa têm mostrado que não só é possível, mas também economicamente viável o emprego de resíduos sólidos provenientes da industrialização da mandioca, como o farelo, na alimentação animal, substituindo parte do milho, considerado um cereal de destino mais nobre (CEREDA, 1994). De fato, a utilização de farelo na alimentação animal é a maneira mais comum de aproveitamento deste resíduo. Há porém diversas outras formas de aproveitar o farelo, que poderiam aumentar surpreendentemente seu valor agregado, através de simples transformações enzimáticas. 


\subsection{Ciclodextrinas}

\subsubsection{Histórico}

Segundo FRENCH (1957), o primeiro relato da existência das CDs foi de Villiers em 1891. Usando técnicas primitivas, Villiers obteve após a hidrólise do amido com Bacillus amylobacter uma pequena quantidade de material cristalino, o qual denominou de "celulosina". Em 1904, Schardinger caracterizou CDs como oligossacarídeos cíclicos e identificou o Bacillus macerans como produtor da ciclodextrina glucanotransferase (CGTase), enzima que modificava a estrutura da molécula de amido. Devido aos estudos de Schardinger, as ciclodextrinas foram inicialmente denominadas de dextrinas de Schardinger. Em 1938, Freudenberg confirmou a estrutura das ciclodextrinas e sua habilidade de formar complexos de inclusão. TILDEN e HUDSON (1939) descobriram uma "amilase" do Bacillus macerans que produzia as CDs. Essa descoberta comprovou que as CDs não eram produtos sintetizados durante o metabolismo microbiano, e sim, resultantes da ação de uma enzima extracelular produzida pelo microorganismo, que hidrolisava amido e compostos relacionados. Foi portanto, por volta de 1950 que as pesquisas sobre CDs chamaram atenção, particularmente com os estudos de Cramer, que descobriu sua atividade catalítica em algumas reações (SAENGER, 1980). KITAHATA e OKADA (1974) foram os primeiros a provar que $\alpha$ e $\chi$-CDs eram produzidas diretamente a partir do amido, não sendo derivações da $\beta$-CD. Esses autores identificaram uma linhagem de Bacillus megatherium capaz de produzir uma CGTase que sintetizava $\alpha, \beta$ e $\chi$-CD na proporção de 1,0:2,4:1,0, enquanto a CGTase do Bacillus macerans mantinha a proporção de 2,7:1,0:1,0.

\subsubsection{Características físico-químicas das CDs}

A cavidade das CDs é composta por átomos hidrofílicos e suas paredes possuem radicais de hidroxila. Enquanto a superfície das moléculas de CDs apresenta natureza hidrofilica, sua cavidade interna possui alta densidade de elétrons e natureza 
hidrofóbica (PSZCZOLA, 1988). O interior da cavidade das CDs é relativamente apolar quando comparado à água (Fig.7), o que propicia às CDs facilidade em formar complexos de inclusão com compostos orgânicos (KIM et al., 1993). As CDs são portanto moléculas que apresentam capacidade de encapsular moléculas hidrófobas, sendo muito empregadas para complexar solventes polares (GEORGANTA et al., 1991). Devido à esta estrutura, possuem a habilidade de formar complexos com compostos sólidos, líquidos e gasosos (Fig. 8). Um dos critérios para complexação é o tamanho da molécula a ser encapsulada, que deve ser compatível com a cavidade da $\mathrm{CD}$ em questão. Outro critério é a polaridade da molécula encapsulada e sua competição com os demais compostos presentes no meio. Os complexos de inclusão são relativamente estáveis e facilmente separados das soluções devido a sua cristalinidade (STARNES, 1990).

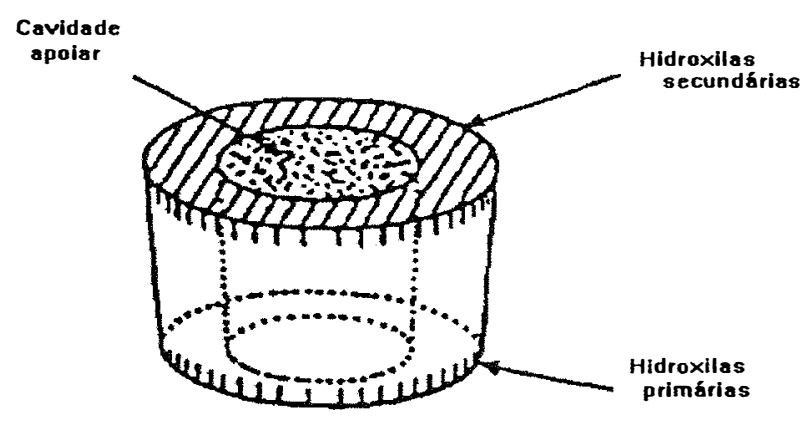

Fonte: SZEJTLI (1990)

Figura 7. Representação esquemática da estrutura funcional das ciclodextrinas. 


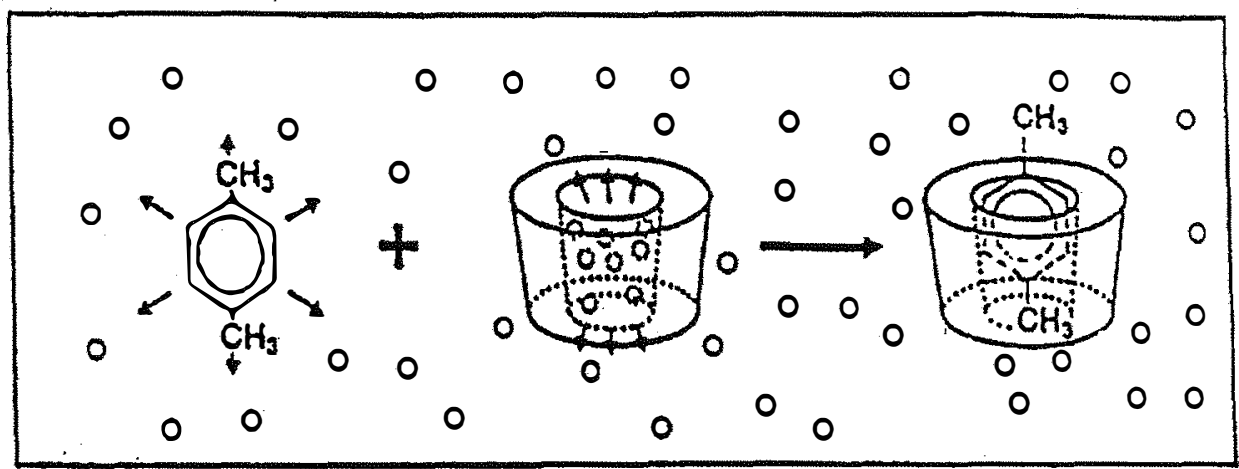

Fonte: SZEJTLI (1990)

Figura 8. Formação de complexo através da encapsulação de molécula de p-xileno por $\beta-C D$.

Três tipos de CDs são conhecidas: $\alpha$-CDs (6 unidades de glucopiranose), $\beta$-CDs (7 unidades de glucopiranose) e $\chi$-CDs ( 8 unidades de glucopiranose) (Fig. 9). Todas são produzidas industrialmente como substâncias cristalinas homogêneas (SZEJTLI, 1982). Dentre as CDs, a $\beta-C D$ tem menor solubilidade em água (FRENCH, 1957) (Tabela 2).

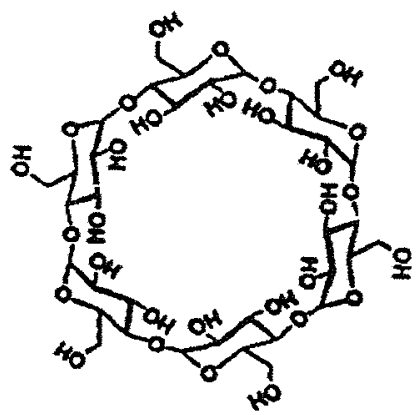

$\alpha$-ciclodextrina

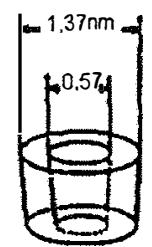

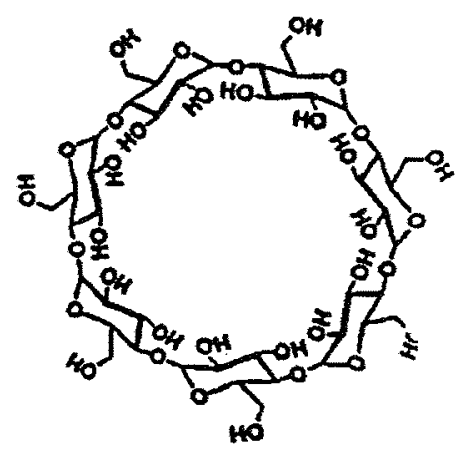

$\beta$-ciclodextrina

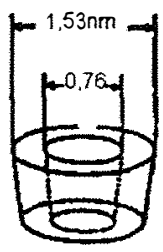

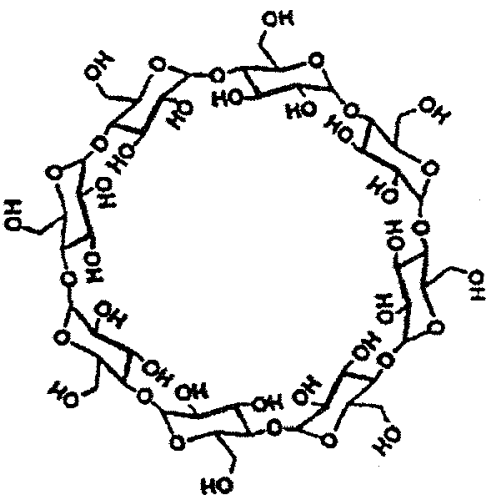

$\gamma$-ciclodextrina

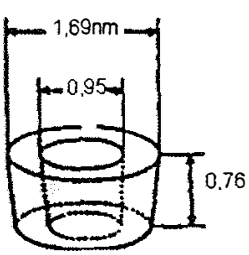

Fonte: PSZCZOLA (1988)

Figura 9.Estrutura de $\alpha, \beta$ e $\chi$-CDs. 
Segundo TABUSHI et al. (1978), as CDs exibem comportamento semelhante ao de uma enzima, em relação ao substrato ligante, sugerindo uma interação específica entre CD e a molécula hóspede. Pontes de hidrogênio (CRAMER e KAMPLE, 1965), interações de van der Waals ou interações hidrofóbicas (NEMETHY e SCHERAGA, 1962), têm sido propostas como forças de interação entre CDs e as moléculas encapsuladas. TABUSHI et al. (1978) relatam ainda que existem muitas dúvidas a serem esclarecidas, tais como a natureza da força de interação, a natureza da estrutura da água próxima ao complexo de inclusão e a dinâmica molecular, entre outras. Estes autores, pesquisando o tipo de interação na encapsulação molecular concluíram que as interações de van der Waals, a energia de conformação e os agrupamentos da água governam o processo de inclusão. Outro fenômeno que tem sido muito estudado é o da participação das CDs na catálise das reações, por apresentarem comportamento típico de enzimas, o que demonstra que as CDs servem como bons modelos em estudos de enzimas (SAENGER, 1980).

Tabela 2. Propriedades físicas das ciclodextrinas

\begin{tabular}{cccc}
\hline Característica & $\alpha-\mathrm{CD}$ & $\beta-\mathrm{CD}$ & $\chi$-CD \\
\hline Número de unidades de glicose & 6 & 7 & 8 \\
Peso molecular (daltons) & 973 & 1135 & 1297 \\
Diâmetro da cavidade $(\AA)$ & 4,5 & 7,0 & 8,5 \\
Profundidade da cavidade $(\AA)$ & $7-8$ & $7-8$ & $7-8$ \\
Solubilidade em água $(\%)$, a $25^{\circ} \mathrm{C}$ & 14,5 & 1,85 & 23,2 \\
\hline
\end{tabular}

Fonte: SABIONI (1991)

Em soluções aquosas, a cavidade apolar das CDs é ocupada por moléculas de água, as quais são energeticamente instáveis (interação polar-apolar) e podem portanto ser prontamente substituídas por outras moléculas da solução que apresentem menor polaridade que as de água. A essência da encapsulação é que uma, duas ou três moléculas de CDs apresentam maior entalpia que as moléculas encapsuladas. CDs geraimente não interferem na atividade de células microbianas, quando em baixas concentrações, o que pode ser de considerável importância industrial. Com algumas exceções, as CDs podem ser 
consideradas como inertes à ação de células microbianas e aos sistemas aquosos enzimas-substratos (SZEJTLI, 1990).

A solubilidade das CDs é aumentada através da adição das mais diversas misturas de água e solventes orgânicos, sendo $\beta-C D$ a mais insolúvel de todas (CHATJIGAKIS et al., 1993). As CDs apresentam sabor doce. Uma solução de 2,5\% de $\alpha$-CD é tão doce quanto uma solução de $1,7 \%$ de sacarose (SZEJTLI, 1990).

$\beta$-CDs já vêm sendo produzidas em escala industrial. Solventes orgânicos foi a primeira alternativa usada para aumentar a solubilidade das $\mathrm{CDs}$, mas não podem ser empregados na indústria alimentícia ou farmacêutica, restringindo assim o uso (SZEJTLI, 1992). A baixa solubilidade da $\beta$-CD pode ser considerada uma vantagem por sua facilidade em ser separada por precipitação seletiva, dispensando a necessidade de tratamentos com solventes orgânicos (YU et al., 1988). A maioria das CGTases são produtoras preferenciais de $\beta$-CDs. Esse fato foi o principal responsável pela queda do preço de $\beta$-CDs nos últimos 10 anos, fazendo com que $\beta$-CDs sejam mais comuns e mais amplamente usadas pelas indústrias. $\alpha$ e $\chi$-CDs porém ainda possuem preços relativamente altos no mercado, principalmente devido ao fato de sua purificação ser mais difícil que a da $\beta$-CD (LEE et al., 1992). A solubilidade relativamente alta das $\alpha$ CDs faz com que sua purificação seja a principal dificuldade na produção em escala industrial (BENDER, 1985). As $\chi$-CDs são de grande interesse industrial devido a amplitude de sua cavidade, porém métodos que reduzam os custos de produção têm sido pouco estudados (BENDER, $1981 \mathrm{~b}$ ).

FUKUDA et al. (1992) verificaram que $\alpha, \beta$ e $\chi$-CDs inibiram a digestão de amido de batata pela glucoamilase proveniente de Aspergillus awamori var. kawachi e, na concentração de 1-5 mM, inibiram $85 \%$ da adsorção de amido pela enzima. A $\beta$-CD foi a que apresentou maior inibição da digestão. Estes autores sugerem que há similaridade entre a estrutura dos grânulos de amido e a das CDs, mas que tal semelhança não ocorre em amido solúvel. Segundo IMBERTY (1988), o amido apresenta molécula de estrutura em forma de hélice, lembrando o anel que constitui as CDs. A estrutura em forma de hélice é desfeita quando ocorre a gomificação do amido, 
levando a conclusão que é por tal motivo que as CDs não competem com o amido solúvel pela adsorção e hidrólise pela glucoamilase. FUKUDA et al. (1992) sugerem que a característica hidrofóbica presente tanto na cavidade das CDs como na hélice do amido ajuda a formar complexos de inclusão.

\subsubsection{CDs modificadas}

\subsubsection{CDs metiladas}

CDs podem ser modificadas quimicamente através da substituição de seus grupos de hidroxilas. Alterando os grupos substituídos, pode-se controlar a solubilidade e seletividade do complexo a ser formado. Muitas dessas CDs modificadas já são produzidas industrialmente, outras apenas em laboratório. CDs metiladas, carboximetiladas e modificadas com epicloridrina originam derivados que são adequados para solubilização de compostos lipofilicos presentes em sistemas biológicos, eliminando assim o inconveniente da toxidez causada pelos solventes orgânicos (SZEJTLI, 1992).

As CDs metiladas são as mais comuns e sua solubilidade aumenta com o grau de metilação, sendo consideravelmente alta quando comparadas com CDs não modificadas. As principais $\beta$-CDs metiladas são DIMEB e TRIMEB (dimetil- $\beta-C D$ e trimetil- $\beta-C D$ ), sendo também conhecidas por heptakis-(2,6-di-O-metil) e heptakis-(2,3,6,-tri-O-metil), respectivamente, sendo obtidas através da metilação seletiva de todos os $C_{2}$ secundários e todos as hidroxilas dos $C_{6}$ primários, enquanto as hidroxilas dos $C_{3}$ permanecem inalteradas. A primeira patente dedicada ao uso de CDs modificadas em fármacos descreve preparo de um componente de baixa solubilidade com DIMEB (SZEJTLI, 1992). DIMEB possui solubilidade em água fria, apresentando-se como solução homogênea e cristalina, que sofre cristalização com o aquecimento. DIMEB pode aumentar a solubilização de esteróides, de progesteronas e de hidrocortisonas, da vitamina $D_{3}$, de fenilatronina, de prostaglandina e de diazepan, entre outros compostos 
largamente empregados na indústria farmacêutica, além de estabilizar compostos instáveis em soluções aquosas. Neste caso, a metilação com $\beta$-CD é mais efetiva para se obter um derivado com alto efeito solubilizante que com $\alpha$ ou $\chi$-CD. A complexação de drogas de baixa solubilidade pelo DIMEB aumenta a massa molecular da molécula hospedeira sem estabelecer ligações covalentes e sem alterar suas características químicas. A estabilidade de complexos formados com derivados de CDs como DIMEB são geralmente maiores que as dos complexos formados com CDs não modificadas. Já os estudos feitos com TRIMEB ainda são escassos (SZEJTLI, 1992).

O tratamento de $\beta$-CDs em meio alcalino com óxido de propileno resulta em ligação entre o grupo 2-hidroxipropil à uma ou mais hidroxilas das $\mathrm{CDs}$, originando $\beta$ CDs hidroxipropiladas, também conhecidas por HPBCD. A HPBCD é comercializada sob a forma de pó branco, porém as com alto grau de hidroxipropilação são semi-sólidas (KITAHATA e OKADA , 1974). São extremamente solúveis em água e etanol. SUMEB (monosuccinil-DIMEB), CDPS (epicloridrina ligada $\beta$-CD) e CDPSI (CDPS contendo grupo carboximetil) são outros tipos de CDs modificadas (SZEJTLI, 1992).

A tabela 3 compara o aumento da solubilidade em diferentes fármacos através do uso de CDs modificadas.

Tabela 3. Fatores de solubilidade de diferentes CDs modificadas

\begin{tabular}{cccc}
\hline Produto & $\beta-\mathrm{CD}$ & HPBCD & DIMEB \\
\hline Diazepan & 3,6 & 2,8 & 90 \\
Digoxin & 90 & 57 & 92 \\
Indometacina & 2,5 & 1,7 & 4,5 \\
Prednisolone & 14 & 9 & 13 \\
\hline
\end{tabular}

Fonte: SZEJTLI, 1992.

Enquanto que na maioria dos casos as CDs aceleram as reações de hidrólise em meio aquoso, as CDs metiladas, nas quais os grupos de hidroxilas são bloqueados, podem inibir tal reação (SZEJTLI, 1992). 


\subsubsection{CDs ramificadas}

Ciclodextrinas ramificadas ( $\mathrm{G} n$-CDs; $n=1,2,3, \ldots$ ) são produzidas a partir da ação da CGTase em dextrinas ramificadas, juntamente com CDs e dextrinas lineares; apresentando alta solubilidade quando comparadas às $\mathrm{CDs}$ não ramificadas. Para produzir G1-CDs em grande quantidade, o substrato deve ser previamente tratado com glucoamilase, convertendo assim $\mathrm{G} n$-CDs $(n=2,3, \ldots)$ em G1-CDs. A quantidade de CDs e CDs ramificadas produzidas durante a reação decresce com a redução da circulação do substrato e com o aumento do tempo de reação. Tal fato se deve à perda da atividade da enzima durante um tempo excessivo de reação (SAKAI et al., 1991). KOBAYASHI e NAKASHIMA (1991) obtiveram CDs ramificadas usando dextrinas ramificadas como substrato. VETTER e THORN (1992 b) produziram CDs ramificadas usando como substrato isomaltose, panose, isomaltotriose e outras dextrinas ramificadas. SAKAI et al. (1991) separaram dextrinas ramificadas de CDs através de ultrafiltração de membrana.

\subsubsection{Polímeros de CDs}

Os polímeros de CDs são constituídos de duas ou mais CDs unidas por ligações covalentes. Seu peso molecular é superior a 10.000. Devido a isso, tais polímeros formam géis insolúveis que podem ser empregados em cromatografia (SZEJTLI et al., 1978).

Outros tipos de CDs também têm sido relatados. OGUMA et al. (1993 b) isolaram cicloisomaltoligossacarídeos de cultura de Bacillus sp. T-3040 isolada de solo. Estes novos tipos de maltoligossacarídeos cíclicos foram identificados como cicloisomaltoheptose, octaose e nanose e, a análise em HPLC revelou grande semelhança com as CDs. A principal diferença entre tais maltoligossacarídeos e as CDs é que os primeiros são constituídos de D-glucoses unidas por ligações tipo $\alpha-1,6$ (OGUMA et al., 1993 b).

Algumas CDs têm sido modificadas com o objetivo de se aumentar sua hidrofobicidade, solubilidade ou o reconhecimento e modo de complexação da molécula 
a ser encapsulada. $\beta$-CDs modificadas com glicose e lactose possuem menor hidrofobicidade quando comparadas às $\beta$-CDs (CHATJIGAKIS et al., 1993).

\subsubsection{Degradação de CDs}

Ciclodextrinas são hidrolisadas em condições ácidas a altas temperaturas e, cerca de $1 \%$ da estrutura do anel de $\beta-\mathrm{CD}$ pode ser hidrolisado com $\mathrm{HCl} 1,15 \mathrm{~N}$, quando submetido a $60^{\circ} \mathrm{C}$ durante 30 minutos (RONG et al., 1992). Em experimento realizado por RAJA et al. (1990), verificou-se que a faixa de temperatura em que ocorre maior degradação de $\beta$-CDs é de 190 a $250^{\circ} \mathrm{C}$.

A literatura sobre a degradação de CDs por enzimas amilolíticas apresenta muitas controvérsias. Segundo YAMAMOTO e HORIKOSHI (1981), 4.600 U de $\alpha$-amilase e $2.400 \mathrm{U}$ de glucoamilase em solução de CDs e dextrinas lineares, quando incubadas a $40^{\circ} \mathrm{C}$ durante 48-72 horas, são suficientes para degradar $\beta$ e $\chi$-CDs. Já BENDER (1993) alega que uma das características das CDs é sua resistência à hidrólise pela maioria das $\alpha$-amilases. Segundo PODKOVYROV e ZEIKUS (1992), taka-amilase degrada CDs. BENDER (1981 b) relata que $\alpha$-CDs são resistentes ao ataque de glucoamilases. SUZUKI e IMAI (1985) constataram que $\alpha$-amilase produzida pelo Bacillus stearothermophilus KP1064 apresentou alta atividade na degradação de $\alpha$ e $\beta$-CDs. Alguns trabalhos ainda relatam que as $\alpha$-amilases pancreáticas e salivares hidrolisam $\chi$ CDs (MARSHALL e MIWA, 1981). KITATHATA e OKADA (1974) usaram glucoamilase para degradar dextrinas lineares à glicose e assim facilitar a quantificação das CDs. Esses autores afirmam que glucoamilase não degrada CDs.

Em trabalhos prévios, observou-se que glucoamilase degrada $\alpha, \beta$ e $\chi$-CDs, ao passo que $\beta$-amilase não degrada CDs (ALVAREZ et al., 1994). Esses resultados apoiam as observações de SAHA e ZEIKUS (1992), que alegam que as CDs não são degradadas por algumas enzimas como $\beta$-amilase e pululanase. Geralmente CDs não são hidrolisadas por exo-amilases devido à ausência de terminais redutores (SZEJTLI, 1983). De acordo com STARNES (1990), as CDs são completamente degradadas à glicose pela ação conjunta de CGTase residual e da amiloglucosidase. SAHA e ZEIKUS 
(1992) explicam a degradação da $\alpha$-CD pela $\alpha$-amilase de Pseudomonas sp. em duas etapas. Na primeira há a ruptura do anel, reduzindo a $\alpha-C D$ a uma maltohexose. Em seguida ocorre a hidrólise das dextrinas lineares que serão reduzidas à moléculas de maltose e glicose. Essa enzima apresenta o que se chama de "ataque múltiplo", ou seja, realiza várias hidrólises sucessivas em diferentes pontos do substrato.

Há também trabalhos que discorrem sobre a degradação das CDs pela ação da CGTase. KOBAYASHI e NAKASHIMA (1991) constataram que dimaltosil e diglucosil-CDs foram resistentes à ação do sistema enzimático CGTase/glucoamilase. Segundo LEE e KIM (1992), a CGTase também degrada CDs na presença de glicose, maltose e sacarose. Estes autores observaram que a adição de solventes orgânicos como butanol e isopropanol reduziu a degradação de CDs propiciada pela CGTase. Segundo estes autores, a formação de complexos entre CDs e solventes impede que a enzima atue na degradação de CDs. MATTSSON et al. (1991) constataram que a adição de etanol retarda a degradação de $\alpha$ e $\beta$-CDs, sendo que a degradação é comumente observada após longo tempo de reação. De acordo com SAKAI et al. (1991), CDs ramificadas são degradadas a maltoligossacarídeos quando a atividade enzimática da CGTase for muito alta para a concentração de substrato. SATO et al. (1994), desenvolveram um método de recuperação de $\alpha-C D$ através de digestão enzimática seletiva de $\chi$ e $\beta$-CD. Esses autores constataram que taka-amilase a $20 \mu / \mathrm{ml}$ decompõe totalmente $\chi-C D$, mas que $\beta-C D$ resiste à degradação, apresentando-se ainda em pequenas quantidades quando submetida a incubação com $200 \mu / \mathrm{ml}$ da enzima. Afirmam ainda que $\beta$-amilase e amiloglucosidase não degradam CDs. SATO et al. (1994) ainda relatam que a combinação de CGTase com $\alpha$-glucosidase promove degradação seletiva de $\beta$ e $\chi-C D$, mas não degrada $\alpha-C D$ (SATO et al., 1994).

Ciclomaltodextrinase (EC 3.2.1.54), também conhecida como CDase, é uma enzima que difere das demais amilases por hidrolisar dextrinas cíclicas e também maltodextrinas lineares. Essa enzima hidrolisa CDs com maior velocidade que amilose ou amilopectina, sendo facilmente diferenciada das $\alpha$-amilases. A CDase não possuem a capacidade de formar CDs, o que a difere da CGTase, a qual além de sintetizar e 
hidrolisar CDs também hidrolisa $\alpha-1,4$-glucanas. A primeira CDase a ser identificada foi isolada do Bacillus macerans por DePINTO e CAMPBELL, em 1968, simultaneamente aos primeiros estudos sobre a CGTase. Esses autores purificaram a CDase do $B$. macerans através de precipitação com sulfato de amônio e cromatografia em gel de Sephadex (DePINTO e CAMPBELL, 1968c). B.coagulans, Clostridium thremoydrosulfuricum e alguns Bacillus alcalofilicos são também produtores de CDase (OGUMA et al., 1993 a). Atualmente há inúmeros estudos que objetivam esclarecer o mecanismo de ação da CGTase, mas são raros os trabalhos feitos sobre CDase. Segundo OGUMA et al. (1993 a), a CDase é uma enzima induzida, ou seja, é sintetizada apenas na presença de CDs, sendo que o substrato mais adequado para induzir sua síntese é a $\beta$ CD.

São descritos vários microorganismos que produzem $\mathrm{CDases}$, entre eles o $B$. sphaericus e Flavobacterium sp. O principal produto obtido a partir da degradação das CDs são oligossacarídeos. Essas enzimas já foram erroneamente denominadas de glucoamilases. Uma vez que tais enzimas apresentam massa molecular muito maior que as $\alpha$-amilases e praticamente não utilizam amido como substrato, é sugerido que elas sejam classificadas como um novo grupo de amilases (BENDER, 1993).

BENDER (1993) pesquisou a ação de CDase produzida por Flavobacterium sp. e verificou que os substratos preferenciais da enzima são maltohexose, maltoheptose e maltooctose. Segundo BENDER (1993), entre as CDs as $\alpha$-CDs são hidrolisadas com maior velocidade, seguidas de $\beta$ e $\chi$-CDs. Esse autor afirma que tal resultado sugere que as $\chi$-CDs possuem maior resistência à degradação enzimática. Entretanto o fator limitante da ação da enzima é a ruptura do anel, sendo que a maltooctose produzida é rapidamente hidrolisada (BENDER, 1993). Alguns autores ainda sugerem que há correlação entre a atividade da CDase e o tamanho do anel a ser hidrolisado, sendo que quanto maior o anel, menor a atividade da enzima (PODKOVYROV e ZEIKUS, 1992; SAHA e ZEIKUS, 1990). A baixa concentração de maltoheptose e $\beta$-CDs observadas por BENDER (1993) indica que houve considerável conversão de maltoheptose em maltohexose e glicose. Neste mesmo trabalho também foi observado que maltose não 
sofreu ataque enzimático, porém maltotriose foi hidrolisada a maltose e glicose. BENDER (1985) ainda sugere que esta enzima seja caraterizada como uma "maltodextrinase desciclizante". OGUMA et al. (1993 a), verificaram que a seqüência de aminoácidos da CDase proveniente do B. sphaericus possui $50 \%$ de homologia com as neopululanases dos B. stearothermophilus e dos Bacillus alcalofilicos. Apesar desta homologia e de possuírem estrutura tridimensional semelhantes, essas enzimas apresentam propriedades enzimáticas diferentes. Quanto às CGTases e às $\alpha$-amilases, as CDases apresentam homologia parcial, sendo que os últimos 180 aminoácidos da região terminal-COOH da CGTase são nitidamente diferentes (OGUMA et al., 1993 a). Ainda segundo OGUMA et al. (1993 a), a deleção da região terminal-COOH da CGTase promove aumento da produção de glicose e maltoligossacarídeos e impede a formação de CDs, indicando sua relação com a reação de ciclização; fato esse que explica a incapacidade das CDases de produzirem CDs. Segundo PODKOVYROV e ZEIKUS (1992), a CDase proveniente do $C$. thermohydrosulfuricum apresenta seqüências similares às da pululanase, CGTase, neopululanase, $\alpha$-amilase e isoamilases, porém com maior semelhança à neopululanase de $B$. stearothermophillus e à $\alpha$-amilase de $C$. thermohydrosulfuricum. .

PODKOVYROV e ZEIKUS (1992) isolaram uma CDase (EC 3.2.1.54) produzida por Clostridium thermohydrosulfuricum 39E, a qual possui máxima atividade a $65^{\circ} \mathrm{C}$ e em pH de 5,9 , sendo que incubação nessas condições resultou em $15 \%$ de perda de atividade após 1 hora. Esses autores também constataram que íons metálicos como $\mathrm{Ag}^{+}, \mathrm{Hg}^{+2}, \mathrm{Cu}^{+2}, \mathrm{Zn}^{+2}$, além de compostos como p-cloromercuribenzoato e $\mathrm{N}$ bromosuccinamida atuam como inibidores dessa CDase. Esses resultados estão em concordância com as afirmações de SAHA e ZEIKUS (1992) de que a atividade das CDases é freqüentemente inibida pelo $\mathrm{Ag}^{+}, \mathrm{Hg}^{+2}, \mathrm{Cu}^{+2}$ e p-chloromercuribenzoato. Ainda em relação à CDase do $C$. thermohydrosulfuricum, PODKOVYROV e ZEIKUS (1992) relatam que essa enzima hidrolisa preferencialmente $\alpha$ e $\beta$-CDs, convertendo-as em maltoligossacarídeos e, posteriormente em maltose e glicose. A taxa de hidrólise de 
amido, amilose, amilopectina e pululana representa apenas $5 \%$ da taxa de degradação de $\alpha$-CDs. A CDase do $C$. thermohydrosulfuricum hidrolisa com maior velocidade $\alpha$-CDs, enquanto que o substrato hidrolisado mais rapidamente pela CDase do Bacillus sp. é maltotriose e maltotetraose (PODKOVYROV e ZEIKUS, 1992). A tabela 4 exemplifica algumas enzimas capazes de hidrolisar CDs.

Tabela 4. Algumas enzimas que degradam CDs.

\begin{tabular}{ccc}
\hline Enzima & Microorganismo produtor & Velocidade de degradação \\
\hline & Bacillus coagulans & Rápida \\
& Bacillus macerans & Rápida \\
Ciclodextrinase & Bacillus sp. & Rápida \\
& Bacteroides sp. & - \\
& Bacillus sphaericus & Rápida \\
& Clostridium & Rápida \\
& thermohydrosulfuricum & \\
\hline$\alpha$-amilase & Aspergillus orizae & Lenta \\
& Bacillus subtilis & Muito lenta \\
& F. capsuligenum & Lenta \\
& Pseudomonas $s$. & Rápida \\
\hline Glucoamilase & T. pullulans & - \\
\hline
\end{tabular}

Fonte: SAHA e ZEIKUS (1992)

Segundo SAHA e ZEIKUS (1992), a CDase proveniente do Bacillus coagulans apresenta peso molecular de 62.000 e é mais ativa a $\mathrm{pH} 6,2$ e à temperatura de $50^{\circ} \mathrm{C}$, sendo estável em temperaturas superiores a $45^{\circ} \mathrm{C}$ e $\mathrm{pH} 7,0$ após duas horas de incubação. A CDase produzida pelo $B$. macerans também possui $\mathrm{pH}$ ótimo 6,2 , sendo que seu peso molecular é 68.000, enquanto a CDase do Bacillus sp. alcalofílico apresenta peso molecular de 126.000, com duas subunidades de 67.000. O peso molecular da CDase do B. sphaericus E244 foi estimado em torno de 144.000, com uma subunidade de 67.000 . A enzima apresenta $\mathrm{pH}$ ótimo de 8,0 e estabilidade a $25^{\circ} \mathrm{C}$. Já a CDase do $B$. ovatus apresenta atividade máxima à temperatura de $45^{\circ} \mathrm{C}$, enquanto a CDase do $B$. distasonis possui atividade máxima e estabilidade a $55^{\circ} \mathrm{C}$ com $\mathrm{pH}$ neutro. No caso da CDase 
produzida pelo Pseudomonas sp., o peso molecular é de 96.000, enquanto a do $F$. capsuligenum tem peso molecular igual a 64.000 (SAHA e ZEIKUS, 1992).

A CDase produzida pelo $B$. coagulans hidrolisa maltoligossacarídeos lineares e $\alpha, \beta$ e $\chi$-CDs com maior velocidade que hidrolisa maltotriose e cadeias curtas de amilose (DP 18), porém não hidrolisa maltose. A CDase hidrolisa ligações $\alpha-1,2, \alpha-1,3 \alpha-1,4$ e $\alpha-1,6$, além de ligações glucosídicas entre D-glucose e fenol, D-glucose e D-glucitol, Dglucose e D-frutose e adjacentes da molécula de maltose (SAHA e ZEIKUS, 1992). Segundo SAHA e ZEIKUS (1992), a identificação do substrato a ser hidrolisado é feita a partir da extremidade não redutora da molécula. Tal observação ressalta a necessidade de maiores estudos sobre o mecanismo de degradação de CDs pelas CDases, uma vez que, segundo SZEJTLI (1983), as CDs não são degradadas pela maioria dos grupos amilolíticos devido à ausência de extremidades não redutoras, uma vez que a molécula é cíclica.

Para a CDase do B. coagulans, os valores de $\mathrm{K}_{m}$ para G3, G4, G5, G6, amilose com DP 18, $\alpha, \beta$ e $\chi$-CDs são 4,5, 4,0, 2,3, 1,5, 1,5, 10, 2,5 e 0,47 mM, respectivamente, sendo portanto sua atividade menor em polissacarídeos como amido e amilose; os quais sofrem taxa de hidrólise relativa a $1 \%$ das CDs (SAHA e ZEIKUS, 1992). Esses valores indicam preferência da enzima em atuar em cadeias curtas. Tais resultados discordam das afirmações feitas por BENDER (1993), de que o decréscimo da atividade ocorre com a diminuição do tamanho das cadeias. Isso pode ser devido ao fato de BENDER (1993) ter trabalhado com CDase proveniente de Klebsiella pneumoniae, enquanto SAHA e ZEIKUS (1992) se referem à CDase do B. coagulans.

Segundo SAHA e ZEIKUS (1992), a atividade da CDase, bem como sua preferência em relação ao substrato, está diretamente relacionada ao microorganismo produtor da enzima. A CDase produzida por Pseudomonas sp. hidrolisa G4, G5 e G6 cerca de 3 a 10 minutos mais rápido que as $C D$, reduzindo praticamente todo o substrato à maltose e glicose. Já a CDase do $B$. ovatus, catalisa apenas a produção de glicose, enquanto a CDase do $B$. distasonis produz vários maltoligossacarídeos. A 
enzima do B. megaterium hidrolisa $\alpha, \beta$ e $\chi$-CDs com formação de dextrinas DP6, DP7 e DP8, as quais serão posteriormente hidrolisadas a DP2 e DP3, ao passo que a CDase do B. sphaericus E244 hidrolisa $\beta$-CDs com maior velocidade que $\alpha$-glucanas. A maioria das CDase não hidrolisa amidos, amilopectina e amilose em quantidades relevantes, sendo que a taxa de degradação destes oligossacarídeos G5, G6 e G7 é de 10 a 70\% menor que a taxa de hidrólise da $\beta$-CD (SAHA e ZEIKUS, 1992). SAHA e ZEIKUS (1990) isolaram uma CDase produzida pelo C. thermohydrosulfuricum, que apresenta $\mathrm{pH}$ ótimo em torno de 6,0 e temperatura ótima a $65^{\circ} \mathrm{C}$, sendo que sua atividade foi inibida na presença de p-clcoromercuribenzoato porém permaneceu inalterada na presença de N-bromossucinamida. Segundo esses autores, a enzima apresentou taxas de hidrólise para amido e amilose de 50 e $53 \%$ respectivamente, enquanto a taxa de degradação de $\alpha, \beta$ e $\chi$-CD foi de 100, 67 e $8 \%$, respectivamente, tendo como produtos da degradação vários tipos de açúcares, entre eles maltose e glicose. Já OGUMA et al. (1991) constataram que a CDase do B. sphaericus hidrolisa duas vezes mais $\beta$-CD que $\alpha-\mathrm{CD}$, enquanto a CDase de Pseudomonas sp. possui maior atividade para $\alpha-C D$, porém a hidrólise de $\beta-\mathrm{CD}$ é muito inferior a de $\chi-\mathrm{CD}$. A CDase de F.capsuligenicum hidrolisa $\beta$-CD oito vezes mais rápido que $\alpha-C D$ (DE MOT e VERACHTERT, 1985). Tais resultados discordam da afirmação que, quanto maior o anel, menor a atividade da enzima refletindo a necessidade de maiores estudos sobre as CDases. A tabela 5 fornece algumas comparações entre diferentes CDases. 
Tabela 5. Comparação entre substratos específicos de CDases de diferentes fontes.

\begin{tabular}{c|cccc}
\hline \multirow{2}{*}{ Fonte de origem } & \multicolumn{4}{|c}{ Atividade relativa (\%) } \\
\cline { 2 - 5 } & $\alpha-\mathrm{CD}$ & $\beta$-CD & $\chi$-CD & Amido solúvel \\
\hline C. thermohydrosulfuricum & 100 & 67 & 8 & 50 \\
Pseudomonas sp. & 100 & 45 & 64 & 48 \\
Aspergillus sp. & 2 & 19 & 72 & 100 \\
A. orizae & 2 & 5 & 65 & 100 \\
F. capsuligenum & 9 & 80 & - & 100 \\
Flavobacterium & 100 & 52 & 62 & 42 \\
B. coagulans & - & 100 & - & 0.69 \\
B. sphaericus & 44 & 100 & - & 2.9 \\
Bacillus sp. & 100 & 65 & 38 & - \\
Saliva & muito & $<11$ & 100 & - \\
Pâncreas & baixa & & & - \\
& muito & $<3$ & 100 & - \\
\hline
\end{tabular}

Fonte: SAHA e ZEIKUS (1992)

Outros trabalhos como de OGUMA et al. (1991), descrevem uma enzima produzida por linhagens de $B$. sphaericus isoladas de solo, a qual hidrolisa $\beta$-CD com maior eficiência que $\alpha$-glucanas. Esta enzima porém apresenta diferença em termos de peso molecular, especificidade de substrato e $\mathrm{pH}$ das CDases já descritas (OGUMA et al., 1991).

\subsubsection{Estudos de toxidez}

SZEJTLI (1990) citou três razões pelas quais a aplicação das CDs não foi aceita de imediato. A primeira seria o alto custo de produção que as levaria a serem vistas apenas como curiosidade científica. A segunda razão seria que, os primeiros estudos sugeriam que fossem tóxicas (FRENCH, 1957). Durante quase duas décadas, o uso de CDs em fármacos e alimentos foi interditado, por lhes atribuírem efeitos tóxicos. A terceira, o fato de que ainda não ocorria produção em escala industrial. Entretanto, estudos mais recentes têm indicado que o consumo oral não é prejudicial e que novas tecnologias se apresentam para 
a produção, sendo as barreiras removidas gradualmente, sugerindo grande aplicação das CDs nas indústrias de alimentos (PSZCZOLA, 1988).

FRENCH (1957), um dos primeiros a estudar o efeito das CDs na alimentação animal, relatou que ratos alimentados com $\alpha$-CDs altamente purificada morreram após uma semana de ingestão da dieta, sendo que os exames "post mortem" não revelaram a causa. Este autor propôs então que as CDs poderiam apresentar efeitos tóxicos devido a capacidade de encapsulação. Embora os experimentos não tenham sido conclusivos, levaram a crer que as CDs exibiam efeito tóxico. Uma provável explicação é que, naquela época, eram utilizados solventes orgânicos como precipitantes para a purificação das CDs, nos quais poderiam estar presentes substâncias tóxicas que resultaram na morte dos animais (HORIKOSHI, 1979). Recentes estudos mostram que CDs apresentam efeitos tóxicos, mas apenas quando ministradas parenteralmente e em altíssimas doses. De acordo com os estudos de FRANK et al. (1976), a administração intravenosa de $\alpha$ e $\beta$-CDs produziu toxidez renal em ratos. A administração de $1.400 \mathrm{mg}$ de $\alpha$-CD e $1.820 \mathrm{mg}$ de $\beta$-CD por $\mathrm{Kg}$ de peso corporal, resultou na morte de $100 \%$ dos animais, após 24 horas. SZEJTLI e SEBESTYÉN (1979), entretanto, consideram essas doses elevadas demais para administração intravenosa. Esses autores constataram a absorção de $\beta$-CDs somente no cólon, apresentando lenta degradação pelas enzimas da flora intestinal, sendo que não houve absorção pelo estômago ou intestino delgado. SZEJTLI e SEBESTYÉN (1979) sugerem ainda que CDs só serão tóxicas se administradas em doses excepcionalmente altas. HORIKOSHI (1979) verificou que a taxa de $\beta$-CDs metabolizadas após 24 horas foi a mesma do amido. Esse autor constatou que não haviam sintomas de toxicidade na administração oral de $0,1,0,4$ e $1,6 \mathrm{~g} / \mathrm{kg}$ de $\beta$-CDs. Determinou as doses letais para ministrações orais, subcutâneas e intraperitonais. Nesse trabalho, o autor ressalta que solventes orgânicos foram usados como precipitantes durante o processo de purificação de CDs. HORIKOSHI (1979) ainda sugere a sua utilização em alimentos e fármacos. A administração oral de hidrolisado de amido (contendo $38 \%$ de $\beta-C D$ e $2,8 \%$ de $\alpha-C D)$ e $\beta-C D$ cristalina (97\% pura), a ratos e cães, em doses diárias de 200, 400 e 600 mg/ Kg de peso corporal, não causou diferenças significativas em relação 
aos animais do grupo controle, segundo testes clínicos e bioquímicos. Os estudos patológicos e histopatológicos realizados após seis meses provaram que não houve alteração dos sistemas digestivo, nervoso central e circulatório. A $\beta-C D$ não apresentou efeito tóxico embriológico ou teratogênico. Nos testes de cromossomos desenvolvidos com ratos, após seis meses, não foi observado aumento da incidência de aberrações espontâneas, ou de mutações (SZEJTLI et al., 1978; SZEJTLI e SEBESTYÉN, 1979). As ciclodextrinas não apresentam qualquer efeito sobre o crescimento de Streptomices (SAWADA et al., 1987).

Há trabalhos que se baseiam na especificidade do complexo formado entre $\beta$ CDs e vários anticorpos para desenvolvimento de métodos que tornem possível quantificar pequenas quantidades de $\beta$-CDs em urina e sangue (CRÉMINON et al., 1994). Tais métodos são de grande utilidade para os estudos de toxicidade com CDs.

Em declaração divulgada pela FAO, não são necessários estudos sobre toxidez em caso de amidos modificados. O Ministério da Saúde Pública do Japão permite o uso de $\beta$-CDs para formação de complexos com "flavors" e pigmentos, antioxidantes e emulsificantes (SZEJTLI, 1990).

Foi constatado que LD 50 (dose letal) de DIMEB via intravenosa em camundongos é $220 \mathrm{mg} / \mathrm{kg}$ e que a administração de $50 \mathrm{mg} / \mathrm{kg} / \mathrm{dia}$ via intramuscular em coelhos durante 12 dias causou necrose renal. Em ratos, doses de $150 \mathrm{mg} / \mathrm{kg}$ não foram consideradas tóxicas, e doses de $50 \mathrm{mg} / \mathrm{kg}$ durante 12 dias não causaram alterações nos testes histopatológicos. Também foi constatado aumento da sobrevivência em camundongos tratados com doses hipervitaminóticas de vitamina $\mathrm{A}$, quando foi ministrado DIMEB via intravenosa (SZEJTLI, 1990). A administração oral de DIMEB em ratos não apresentou efeitos tóxicos (SZEJTLI, 1992).

HPBCD, em experimentos feitos "in vitro", demonstrou ser menos suscetível ao ataque de $\beta$-amilase que $\beta$-CD. Quando administrado oralmente, HPBCD foi excretada sem ser absorvida ou metabolizada pelo organismo. Em doses superiores a $10.000 \mathrm{mg} / \mathrm{kg}$ via intraperitonal e de $2.000 \mathrm{mg} / \mathrm{kg}$ via intravenosa não causaram danos à saúde de camundongos. Em estudos preliminares no organismo humano, para administração 
intravenosa de doses diárias de $1 \mathrm{~g}$, não foram observados sintomas de toxicidade. Estudos detalhados sobre toxicidade mostram que altas doses de HPBCD são bem toleradas parenteralmente. Baseados neste resultados, há expectativa da aprovação do uso de HPBCD em preparo de drogas injetáveis (SZEJTLI, 1992).

\subsubsection{Efeito das CDs no metabolismo}

$\mathrm{Na}$ literatura, os trabalhos sobre valor nutricional das ciclodextrinas são bastante escassos. SUZUKI e SATO (1985), realizaram vários testes com ratos, visando avaliar a digestibilidade e absorção das $\alpha$ e $\beta$-CDs em ratos alimentados com dietas suplementadas com CDs, durante 110 dias. Foram ministradas doses de 1,2 a 1,5 mg de $\alpha$ ou $\beta$-CDs por rato (peso médio de $464 \mathrm{~g}$ ). Excreções fecais coletadas no intervalo de 12 a 60 horas apresentaram cerca de $60 \%$ de $\alpha-C D$, porém a quantidade de $\beta-C D$ observada foi desprezível. O resultado foi semelhante no que diz respeito às medidas dos efeitos residuais no trato intestinal. No período de 3 a 8 horas após a digestão, foram medidos os efeitos residuais no trato digestivo, no estômago e no intestino grosso e delgado. Não ocorreu digestibilidade de $\alpha-\mathrm{CD}$ e seus níveis no trato digestivo foram consideravelmente maiores que os de $\beta-C D$.

Em outro experimento, ratos foram alimentados com preparados comerciais de $\alpha$, $\beta$ e $\chi$-CDs, em percentuais de 19,5; 39,0; 58,8 e 78,0 em relação a dieta controle. Houve redução no ganho de peso durante o desenvolvimento e redução na taxa de triglicerídeos livres (TG) no sangue nos ratos que foram tratados com dietas ricas em CDs. Diferenças significativas foram observadas entre o ganho de peso do controle e dos ratos alimentados com dietas a 58,8 e 78,0 \% de CDs. Durante os 40 dias iniciais, a eficiência alimentar foi significativamente menor no grupo alimentado com 78,0\% de CDs. Nas análises das excreções fecais, não foi observada a presença de $\chi$-CDs, sendo $\alpha$-CDs predominantes. Quando comparados com o controle, os demais tratamentos mostraram reduções significativas nas concentrações de TG livres. Diferenças consideráveis foram observadas

nos níveis de TG em grupos alimentados com dietas superiores a 39\% de CDs. Doses de 
0,1 a $1,6 \mathrm{~g}$ de $\beta$-CDs/kg peso/dia não influenciaram o ganho de peso e $\chi$-CDs apresentaram alta digestibilidade, quando comparadas a $\beta$ e $\alpha$-CDs (BOOCOCK e CAMILLERI, 1985).

Assim, efeitos como baixa digestibilidade e perda de peso podem ser aribuídos a $\alpha$-CDs, quando ministradas na dieta. Alguns autores sugerem que CDs possivelmente podem ser usadas para reduzir calorias em dietas que visam o controle de peso, tendo ainda a vantagem de reduzir a taxa de TG livres (SZEJTLI, 1981).

\subsubsection{Aplicação industrial das CDs}

A aplicação das CDs na biotecnologia começou apenas por volta do ano de 1980, mas um rápido desenvolvimento é esperado nesse campo (SZEJTLI , 1990).

SAENGER (1980), relata que mais de 600 trabalhos publicados nos últimos dez anos discutiam o uso das ciclodextrinas. Esse grande número de pesquisas na área foi acompanhado por aumento de patentes nos últimos 20 anos, refletindo o crescente interesse por ciclodextrinas e sua transformação de curiosidade científica para objeto de interesse industrial.

No final dos anos 60, a maior refinadora de milho americana abandonou a produção de CDs, devido ao alto custo de produção. Desde então, numerosas opções para a produção de CDs por hidrólise enzimática do amido tem sido propostas na literatura e os processos de purificação tem sido aprimorados (PSZCZOLA, 1988). No Japão, a produção industrial de CDs atinge 600 ton./ano, e a maior parte do produto tem sido utilizada pela indústria alimentícia (SHIRAISHI et al., 1989).

\subsubsection{Em alimentos}

Segundo HORIKOSHI (1979) e SAENGER (1980) a utilização das CDs pelas indústrias se apresenta, entre outros melhoramentos, a estabilização e prevenção de oxidações e de degradações por UV, a modificação da atividade química da molécula hospedeira, a fixação de substâncias muito voláteis, a estabilização de "flavors", a alteração de cores, de fluorescências e de sabor amargo; o aumento da solubilidade de substâncias 
pouco solúveis em água, a emulsificação de esteróis, de óleos, de gorduras e de ácidos graxos e a solidificação de hidrocarbonetos, de óleos e de ácidos graxos.

KONNO et al. (1981) observaram que a adição de $0,3 \%$ de $\beta-C D$ aos sucos cítricos reduziu sensivelmente o amargor conferido pela naringina e limonina. A aplicação desses polímeros na remoção de componentes responsáveis pelo amargor de sucos cítricos tem sido estudada por diversos pesquisadores. SZEJTLI (1990) relata que a adição de $10 \%$ de $\beta$-CD eliminou completamente o sabor amargo em hidrolisado protéico de caseína. SCHLIMME (1990) realizou trabalhos que demonstram que CDs podem ser usadas na remoção de colesterol de leite integral.

Um dos mais estudados usos potenciais das CDs é a complexação de "flavors". A maioria dos compostos usados como aromatizantes são voláteis e apresentam alta sensibilidade a luz, sofrendo oxidação e destruição (SZENTE et al., 1988). Portanto os aromatizantes necessitam ser embalados hermeticamente com exclusão de ar e luz. SZENTE et al. (1988) verificaram o uso de CDs como estabilizador de óleos voláteis de chá que, quando em contato com água quente, são rapidamente liberados. Foi feita a preparação de complexos de inclusão de óleos essenciais de jasmim, de limão e de menta com $\beta$-CDs, os quais foram avaliados quanto a estabilidade ao armazenamento em altas temperaturas e ao calor. Cromatografia gasosa e testes sensoriais revelaram que não houveram alterações entre as moléculas originais e as encapsuladas no que diz respeito à composição e características. As moléculas encapsuladas com CDs apresentaram menores taxas deterioração dos compostos voláteis, quando comparadas às moléculas originais. Os estudos temoanalíticos mostraram que a degradação dos compostos voláteis foi retardada, quando complexados com CDs, sendo que o ponto de volatilização foi alterado de $100^{\circ}$ $130^{\circ} \mathrm{C}$ para $180^{\circ} \mathrm{C}$. Os complexos de CDs/óleos essenciais, armazenados a altas temperaturas $\left(80^{\circ} \mathrm{C}\right)$, apresentaram perdas de compostos voláteis significativamente menores (SZENTE et al., 1988).

Estudos similares foram feitos com "flavors" naturais e sintéticos de café. Os componentes do aroma do café são quimicamente diferentes (cíclicos, acíclicos e heterocíclicos), sendo a grande maioria rapidamente volatilizados e alguns quimicamente 
instáveis (SZENTE e SZEJTLI, 1986). Durarıte o preparo do extrato do aroma de café e produtos de café solúvel, a perda de vários componentes do "flavor" diminui acentuadamente o valor sensorial do produto. A estabilização do aroma de café tem sido obtida através do uso de alguns antioxidantes ou através da remoção de constituintes marcantes no sabor, como ésteres de diterpeno e esteróis provenientes de óleos de café. A estrutura química, polaridade e dimensões moleculares da maioria dos constituintes do "flavor" do café, são favoráveis a complexação com $\beta$-CDs. O acréscimo de $\beta$-CDs em bebidas quentes de café revelou um método conveniente de diminuir o gosto amargo da bebida (SZENTE e SZEJTLI, 1986). Em trabalho realizado por SZENTE e SZENTJLI (1986) com furfurilmercaptana, o principal componente do flavor do café; largamente usado na indústria alimentícia, resultados satisfatórios foram obtidos com a complexação de $\beta$-CDs. A avaliação de perda de "flavor" durante seis semanas de armazenamento a $60^{\circ} \mathrm{C}$ mostrou que os complexos de aromas naturais e sintéticos com $\beta$-CDs apresentaram perdas de $20 \%$, enquanto o controle apresentava perdas de $80-90 \%$. Os componentes do "flavor" também apresentaram maior estabilidade a luz, especialmente ultravioleta, quando complexados com $\beta$-CDs.

LINDER et al. (1981) estudaram a encapsulação de extratos aromáticos de alho, alecrim, mostarda, cebola, entre outros, com $10 \%$ de $\alpha$-CD. Os complexos resultantes eram estáveis por longo tempo de armazenamento, sem qualquer perda de aroma, e isentos de impurezas microscópicas. Esses autores também relatam que houve preferência por parte dos provadores por alimentos formulados com aromas complexados com CDs. Segundo YE et al. (1991), a complexação de moléculas aromáticas por CDs provoca substituição eletrofilica dos anéis aromáticos encapsulados, formando um composto intermediário com uma carga positiva deslocada. Esse composto seria estabilizado pelos elétrons da cavidade das CDs (YE et al., 1991). De acordo com RENDLEMAN (1992), há estreita correlação entre a estabilidade de complexos formados por $\mathrm{CDs}$ e sua solubilidade, sendo que quanto maior a solubilidade, maior será a estabilidade. Estudos feitos com complexação de CDs em sakê revelaram diminuição da 
taxa de evaporação de compostos aromáticos e de etanol e aumento da resistência a variações térmicas (ITO et al., 1988).

Segundo SHIMADA et al. (1992), o complexo de inclusão formado por CDs e triglicerídeos é usado como emulsificante no preparo de emulsões de óleo e água. Alguns autores observaram a formação de complexos de CDs com ácidos orgânicos e com fosfatilcolina (SHIMADA et al., 1992). Em trabalho feito por SHIMADA et al. (1992), foi observado que altas concentrações de CDs, quando adicionadas a uma emulsão de óleo vegetal, interferem na tensão superficial atuando como agente surfatante. SHIMADA et al. (1992) afirmam que complexos de CDs com triglicerídeos diminuem a tensão interfacial quando se usa soluções de $\alpha-C D$ e $\beta-C D$, nas concentrações respectivas de $0,25 \%$ e $0,68 \%$. Ainda segundo esses autores, tais resultados sugerem que os complexos de inclusão de CDs e triglicerídeos são formados de acordo com o tamanho da cadeia de ácidos graxos presente na interface. $\mathrm{O}$ ácido graxo forma complexo com duas ou três moléculas de CDs, sendo que a proporção de moléculas de $\alpha$ e $\beta$-CDs para moléculas de ácido graxo de óleo de soja é 2,4:1,0. No caso do óleo de coco este valores são de 1,8 moléculas de $\alpha$-CD e 1,7 moléculas de $\beta$ CD para cada molécula de ácido graxo. Segundo LAAKSO et al. (1992), as CDs apresentam alta especificidade de interação com ácido linoleico.

O pigmento presente na carne curada, dinitrosil ferrohemocrome (DNFH), é tido como principal responsável pela coloração vermelha e é formado através da reação do nitrito presente no sistema de cura e da hemoglobina. O principal inconveniente do DNFH é sua alta suscetibilidade à oxidação na presença de luz e oxigênio (O'BOYLE et al., 1992). Esses autores encapsularam DNFH com gomas arábicas (BDH; Chemicals Toronto), maltodextrinas com DE 4 a 25 (Maltodextrin M-040 e Maltodextrin M-250; Grain Processing Corp.), amido modificado (N-Lok; National Starch and Chemical Corp.) e $\beta-C D$ (Saranko Inc.). Esses ingredientes foram usados isoladamente ou combinados e foram avaliados a qualidade e tempo de preservação da coloração de carnes curadas. Usando somente $\beta-C D$ como agente encapsulador, os autores obtiveram notas 9,5/10 na avaliação da coloração, enquanto que os tratamentos que usaram amido 
modificado ou maltodextrina, isoladamente, obtiveram notas de 5,5/10. Os tratamentos com $10 \%$ de goma arábica, $20 \%$ de $\beta$-CD e $70 \%$ de amido modificado obtiveram notas de 7,5/10. Já tratamentos que usaram combinações entre $\beta-C D$ e amido modificados e $\beta$ CD e maltodextrinas apresentaram notas de 10/10 a 8,5/10 em função das proporções usadas. O tempo de exposição necessário para a oxidação do pigmento é de 4-6 horas na presença de luz e oxigênio, 24-30 horas somente na presença de ar, 21 dias somente na presença de luz e 31 dias na ausência de ambos. Com pigmento encapsulado com $\beta-C D$ isolada ou combinada com maltodextrinas ou amido modificado, houve aumento do tempo de conservação da cor da carne. Concluí-se que goma arábica não é um agente encapsulador adequado para DNFH, enquanto que $\beta-\mathrm{CD}$ é excelente, podendo ser usado isoladamente ou em combinação com outros agentes. Foi relatado que tanto maltodextrinas como amidos modificados devem ser combinados com $\beta-C D$ para que a encapsulação seja efetiva. Os autores atribuíram a qualidade e estabilidade do pigmento encapsulado pela $\beta-C D$ às propriedades físicas adequadas como o tamanho da cavidade da molécula $(7,8 \AA)$ e à afinidade com a molécula de DNFH, conferida pelas ligações que possuem nitrato.

O uso de $\beta$-CDs como agente encapsulador apresenta problemas como sua baixa solubilidade em água $\left(1,85 \mathrm{~g} / 100 \mathrm{ml}\right.$ a $\left.25^{\circ} \mathrm{C}\right)$. Tal problema pode ser contornado adicionando $\mathrm{NaOH}$ na solução. Outro problema da $\mathrm{CD}$ é seu alto custo, que, no caso do DNFH, pode ser minimizado com a combinação $\beta-C D$ à $20 \%$ e amido modificado ou maltodextrina à 80\% (O'BOYLE et al., 1992).

As $\alpha$-CDs podem ser classificadas como fibras dietéticas, sendo bom substituto calórico e podendo ser empregadas em dietas de controle de peso (LEE et al., 1992).

\subsubsection{Em fármacos}

LACH e COHEN (1963) verificaram que $\beta$ e $\alpha$-CDs aumentaram a solubilidade de diversos compostos fármacos em água, entre eles a sulfadiazina, a morfina, o ácido benzóico, a vanilina e a benzocaína. THAKKAR et al. (1972) constataram que $\beta$-CD forma complexos de inclusão com barbituratos, aumentando sua solubilidade em água. As 
prostaglandinas são efetivos agentes estimulantes da musculatura lisa, mesmo em diminutas quantidades, entretanto são muito instáveis. A complexação com CDs provou ser um excelente método para estabilizá-las e aumentar a sua solubilidade em água (SZEJTLI, 1982). A produção de antibióticos do grupo lancacidina foi bastante estimulada pela adição de $\beta$-CD ao meio de fermentação (SZEJTLI, 1981).

SAWADA et al. (1987) constataram que a adição de $\beta-C D$ ao meio de cultura de Streptomyces sp. estimula consideravelmente a produção de antibióticos do grupo lancacidina. Estes autores ressaltam que, no caso de promover aumento da produção de antibióticos, $\beta$-CD é mais eficiente que $\alpha$ e $\chi$-CD. A adição de $\mathrm{CDs}$ não propiciou alteração significativa no crescimento microbiano, consumo de carbono ou $\mathrm{pH}$ do meio de fermentação. As CDs não foram metabolizadas pelos microorganismos, fato que sugere que o aumento da produção de antibióticos é resultante da formação de complexos de inclusão entre lancacidina e CDs (SAWADA et al., 1987).

Em trabalho feito por HODI et al. (1991) foi constatada alteração na morfologia original de produtos obtidos a partir de Paracetamol em pó. Tais alterações foram em função da forma de preparo e da adição de $\beta$-CDs. O uso de $\beta$-CDs na formulação de tais drogas aumenta a adesividade do material, sendo seu uso adequado na síntese de drogas que são comercializadas na forma de pó (HODI et al., 1991).

A encapsulação de própolis por $\beta$-CDs propiciou maior estabilidade ao tratamento de álcali usado no processo de solubilização do própolis e maior estabilidade ao calor (SZENTE e SZEJTLI, 1986). Ciclodextrinas também estão sendo usadas como estabilizante de compostos de aspartame (OJIMA et al., 1986).

\subsubsection{Efeito sobre o crescimento microbiano}

MAHMOUD et al. (1990) constataram que a adição de $\beta$-CDs aumentou a taxa de conversão do substrato benzaldeído em L-phenylacetyl carbinol (L-PAC), realizada por células imobilizadas de Saccharomyces cerevisae ATCC 834. Esses autores obtiveram uma produção de L-PAC quase três vezes maior com acréscimos de 0,5 a $1,5 \%$ de $\beta$-CDs ao meio de cultura. Neste mesmo trabalho observou-se que nos 
tratamentos com adição de $\beta$-CDs a população microbiana teve acréscimo de $30 \%$ em relação ao controle, além de aumento na velocidade de consumo de glicose. Os autores atribuíram o acréscimo da produção de L-PAC dos tratamentos com adição de $\beta$-CDs à remoção ou diminuição do efeito tóxico do benzaldeído no metabolismo das leveduras imobilizadas e a complexação do L-PAC, diminuindo a inibição ocasionada pelo produto durante bioconversão.

Efeitos similares foram observados por SZENTE et al. (1990) com Mycobacterium lepraemurium, que teve estimulado seu crescimento e síntese de ácidos graxos através da adição de CDs.

\subsubsection{Outros}

SAENGER (1980), relata que as piretrinas são muito tóxicas aos insetos e pouco tóxicas aos animais homotérmicos. Elas consistem em óleo amarelado com grande sensibilidade a luz, o que tem dificultado seu emprego como inseticida. Entretanto, a inclusão de piretrinas com $\beta$-CD forma um pó facilmente manuseável, muito estável e tóxico aos insetos, após longo período. BOOCOCK e CAMILLERI (1985) verificaram que a solubilidade de inseticidas sistêmicos e de contato é consideravelmente aumentada quando complexados com CDs, permitindo diminuição na quantidade de ingrediente ativo usado. SZEJTLI e OLAH (1983) também relataram o uso de CDs para a formação de complexos com piretrinas, clorados e paration-metil. Alguns estudos mostram porém, que a complexação de herbicidas como atrazina e simazina por $\beta$-CDs podem torná-los ineficientes, sendo visto a utilização de CDs como agentes que minimizam a contaminação ambiental (DAILEY et al., 1990).

SZEJTLI (1983) observou interações entre CDs e amilose ou outros compostos que apresentam altas atividades em baixas concentrações como fitormônios. Esse autor afirma que tais interações alteram a fisiologia da planta podendo eventualmente apresentarem importância prática. O mecanismo de ação das CDs nos vegetais ainda não está totalmente elucidado. Sabe-se que sementes de cereais imersas em solução de CDs apresentam retardo na germinação e no desenvolvimento de raízes, mas que o 
desenvolvimento das plântulas do terceiro ao sexto dia é significativamente mais vigoroso que o controle e que $\beta-C D$ é mais efetiva que $\alpha-C D$. Em plantas com três semanas de idade irrigadas com solução de CDs foi observado produção de massa verde $27-29 \%$ maior que à do controle, $10 \%$ a mais de altura e $20 \%$ a mais de matéria seca. Em aveia se observou um aumento na produção de 1,2\% e em cevada 2,4\%. Em experimento anterior porém, houve uma redução de $6,3 \%$ da produção de cevada tratadas com CDs, quando comparado ao controle, mostrando contradição com os resultados anteriores e indicando que os efeitos da CDs são bastante influenciados por condições ambientais. No caso de monocotiledôneas, as CDs causaram inibição do desenvolvimento de raizes e decréscimo do peso fresco, mas o conteúdo de matéria seca aumentou em relação ao controle. Ocorreram também aberrações morfológicas em função da redução do teor de água absorvido pela planta, sendo que as raízes ficaram mais curtas e grossas. Já nas dicotiledôneas o efeito da absorção de CDs foi oposto, apresentando raizes mais longas e aumento da quantidade de água absorvida. Os resultados de experimentos realizados em casa de vegetação mostraram que sementes de milho tratadas com soluções de $1 \%$ de $\beta$ CDs apresentam menor suscetibilidade aos efeitos fitotóxicos causados pelos herbicida Alafon, na dose de $3 \mathrm{~kg} / \mathrm{ha}$. É suposto que a diminuição do efeito fitotóxico dos herbicidas causado pela aplicação de soluções de CDs é devido ao retardo da germinação das sementes, possibilitando assim aumento da resistência da cultura aos efeitos prejudiciais dos herbicidas sem afetar sua ação nas plantas daninhas (SZEJTLI , 1983).

Segundo RONG et al. (1992), modelos de flavoenzimas são formados por um sítio covalente que se acoplará ao sítio catalítico de um derivado de flavina. Estudos recentes usam $\alpha$-CDs como sítio covalente, enquanto as $\beta$-CDs apresentam maiores dificuldades para serem usadas como flavociclodextrinas. Do ponto de vista químico, as flavociclodextrinas apresentam-se como os melhores modelos para se entender o comportamento das flavoenzimas devido à capacidade das CDs de encapsularem moléculas orgânicas (RONG et al., 1992). KOMIYA et al. (1990) usou complexos de $\chi$ CD como modelo para elucidar a autoxidação de lipídios. Segundo DRIOLI et al. (1995), devido ao fato do fenômeno de encapsulação das CDs apresentar semelhanças à 
algumas reações enzimáticas, as CDs têm sido usadas como modelos para estudos de certas enzimas. Para os mesmos autores, nos últimos anos muitos estudos sobre modificações de membranas por CDs, bem como suas influências na separação de compostos, têm sido conduzidos. Esses autores realizaram experimentos com $\beta-C D$ modificadas ( $\beta-\mathrm{CD} / \mathrm{O}$-octiloxicarbonil) em reatores de membrana de PEEK-WC (poli(oxa-p-fenil-3,3-ftalido-p-fenil-enxoxa-p-fenilenoxi-p-fenileno)) em reação com pnitrofenilacetato (PNPA) para produção de p-nitrofenol. A varredura feita por microscopia eletrônica revelou que os poros das membranas com PEEK-WC/CD apresentaram maior regularidade e homogeneidade. Aumento da concentração de pnitrofenol em membranas com CDs foi observado, indicando que membranas com $\beta-C D$ (PEEK-WC/CD) catalisam a reação com maior eficiência que membranas que possuem apenas íons de hidróxido (PEEK-WC).

As CDs podem ser polimerizadas com epicloridrinas, obtendo-se resinas que podem ser utilizadas em cromatografia de gel. Efeitos especiais de separação puderam ser obtidos durante a cromatografia, devido a inclusão molecular (WIEDENHOF, 1969).

\subsubsection{Mercado potencial}

Ciclodextrinas têm sido empregadas na Hungria e Japão desde 1970. Bélgica, França, Holanda, Itália, Luxemburgo, Espanha e Alemanha são países que tem o uso de CDs aprovado em alimentos. Nos EUA, CDs começaram a ser produzidas pela Americam Maize Products Co., porém até 1990 seu uso em alimentos ainda não havia sido aprovado pela U. S. Food and Drug Administration (STARNES, 1990).

Até o presente momento o maior problema que limita sua utilização na indústria alimentícia é o alto custo de produção, superior ao dos amidos modificados (O'BOYLE et al., 1992; KIM et al., 1993). Em 1990, a produção de $\alpha$-CD foi estimada em 3 toneladas, enquanto que a de $\beta$-CDs foi de aproximadamente 1.000 toneladas (DELBOURG, 1991).

No Japão, CDs são largamente usadas em várias indústrias como a alimentícia, de fármacos, cosméticos e defensivos agrícolas, sendo que a matéria prima normalmente 
empregada é o amido de batata e a produção é feita por batelada (OKADA et al., 1994 b). Nesse país, as CDs têm seu uso em alimentos autorizado desde 1976. A produção de CDs no Japão teve início em 1978 e desde 1983 vêm sendo empregadas em fármacos. Sua utilização na indústria tornou-se significativa a partir de 1986. A Nihon Shokuhin Kato Co. foi a primeira indústria a produzir CDs e atualmente sua produção de $\beta$-CDs está estimada entre 600-900 t/ano. A Hungria, o segundo país produtor de CDs, produz essencialmente $\beta$-CDs e a França começou a se posicionar neste mercado há pouco tempo (DELBOURG, 1991). A tabela 6 lista os principais países produtores de CDs, bem como suas indústrias.

Tabela 6. Principais países produtores de CDs, suas indústrias e produtos.

\begin{tabular}{ccc}
\hline País & Indústria & Tipo de CDs \\
\hline & Nihon Shokulhin Kato & $\alpha, \beta$ e $\chi$-CDs \\
Japão & Saranku Ocean & $\beta$-CDs metiladas \\
& Toyo Joso & $\alpha$ e $\beta$-CDs \\
& Ensuiko Seiko & $\alpha$ e $\beta$-CDs \\
& Hayashibara & CGTase \\
& Amano Pharmaceutical & CGTase \\
\hline Hungria & Chinoin & $\beta$-CDs \\
\hline \multirow{2}{*}{ França } & Roquette Frères & $\beta$-CDs \\
& Orsan & $\beta$-CDs \\
\hline Holanda & Rhône Poulenc & $\beta$-CDs \\
\hline Bélgica & Avebe & - \\
\hline Alemanha & Janssen & $\beta$-CDs hidroxipopiladas (HPBCD) \\
\hline
\end{tabular}

Fonte: DELBOURG (1991)

Só nos EUA, o mercado potencial de CDs movimentaria 32.000 toneladas por ano; ou seja, o equivalente a U\$245 milhões. Em 1990, a $\beta$-CD estava cotada entre U\$15-20/ kg, no Japão e Europa. $\alpha-C D$ está cotada em torno de U\$40/Kg enquanto que o preço de $\chi$-CDs varia entre $U \$ 200$ e $1.200 / \mathrm{Kg}$. A HPBCD tem seu preço entre U $\$ 60$ e 200/kg (DELBOURG, 1991). Para que conquistem o mercado, o preço da $\beta$-CD deve baixar a U $\$ 5 / \mathrm{kg}$, e deve ser aumentada a produtividade de $\alpha$ e $\chi$-CDs (STARNES, 1990). Este mesmo autor é categórico quando afirma que o crescimento do uso de CDs no mercado está dependendo apenas de métodos de avaliação individual de CDs e de sua 
queda de preços. Aumento de atividade enzimática, otimização das condições de reação, novos métodos de recuperação e purificação têm sido os meios mais estudados para se aumentar a produção de CDs (STARNES, 1990). Trabalhos visando a minimização dos custos de substratos porém são escassos.

\subsection{CGTase}

\subsubsection{Características da CGTase}

Uma das primeiras pesquisas sobre o modo de ação da enzima ciclodextrina glucanotransferase (CGTase; EC 2.4.1.19) foi feito por DePINTO e CAMPBELL (1968 a). Nesse trabalho, os autores se referiam à CGTase produzida pelo B. macerans como uma "amilase" capaz de sintetizar CDs a partir de maltotetraose, maltopentose, maltohexose e maltoheptose. Esses autores também afirmaram que a maior parte das $\alpha$ CDs produzidas eram rapidamente convertidas em $\beta$ e $\chi$-CDs e identificaram outra enzima produzida pelo mesmo microorganismo, a ciclodextrinase, a qual era capaz de degradar CDs mas não de sintetizá-las. No mesmo ano, estes autores purificaram a CGTase produzida pelo B. macerans e, através de eletroforese constataram que o peso molecular da enzima era equivalente a 139.300 (De PINTO e CAMPBELL, 1968 b).

Segundo KANEKO et al. (1990 b), há quatro tipos de CGTases: a CGTase produtora de $\alpha-\mathrm{CD}$; produzida pelo B. macerans, B.amyloliquefasciens e Klebsiella pneumoniae, a CGTase formadora de $\beta-\mathrm{CD}$; obtida através de culturas de B. circulans, B. megaterium e algumas linhagens de Bacillus alcalofílicos, a CGTase formadora de $\alpha$ e $\beta-C D$; a qual é produzida por B. stearothermophilus e $B$. coagulans e a CGTase produzida pelo $B$. subtilis, a qual proporciona principalmente a obtenção $\chi$-CD. Estes autores observaram que a CGTase quimérica proveniente de linhagens mutantes de Bacillus alcalofílico produziu quantidades maiores de $\alpha$-CDs quando comparada a CGTase obtida das linhagens selvagens, sendo que ambas enzimas apresentavam baixa produção de $\chi$-CD. A CGTase quimérica também aumentou a velocidade de conversão 
de substratos com altas concentrações de amido em $\alpha-C D$, além de retardar a degradação e conversão de $\alpha$-CD (KANEKO et al., 1990 b).

Em eletroforese da CGTase de Bacillus alcalofílico feita por KIMURA et al. (1990), foram obtidas duas bandas com peso molecular estimado entre 60.000 e 66.000 . KANEKO et al. (1990 b) submeteram as CGTases 17-1 e 38-2 purificadas a eletroforese em gel SDS-poliacrilamida (LAEMMLI , 1970) e constataram que tais enzimas apresentaram peso molecular próximo a 75.000, verificando que não houve alteração significativa no peso molecular das enzimas quiméricas. NAKAMURA e HORIKOSHI (1976) verificaram que CGTase proveniente de Bacillus sp. (ATCC21783), após ser purificada por diálise e coluna de Sephadex G-150, apresentou peso molecular em torno de 85.000-88.000 em eletroforese em gel de SDS-poliacrilamida.

A solubilidade da enzima é relativamente baixa quando em soluções neutras ou ácidas (MÄKELÄ et al., 1990). Talvez este fato justifique a observação feita por NAKAMURA e HORIKOSHI (1977), que afirmam que CGTase do Bacillus sp. 1011 produz mais CDs em pH alcalino que em pH ácido. NAKAMURA E HORIKOSHI (1976) sugerem que, dependendo do microorganismo produtor, as CGTases apresentam diferentes $\mathrm{pH}$ ótimos de atividade; na faixa de 4 a 10, alterando consideravelmente a quantidade de CDs produzidas. Baseado nestas diferenças, esses autores classificam as CGTases em ácidas, neutras e alcalinas.

Em trabalho feito por NAKAMURA e HORIKOSHI (1976) visando comparar as propriedades de CGTases neutras, ácidas e alcalinas, foi constatado que a CGTase neutra apresenta atividade máxima em $\mathrm{pH} 7,0$ e temperatura de $50^{\circ} \mathrm{C}$ e estabilidade após 30 minutos de incubação a $60^{\circ} \mathrm{C}$. Esses autores ainda sugerem que a CGTase neutra é mais lábil que a CGTase ácida, a qual é estável em pH superior a 10, sendo que pHs baixos resultam em perda considerável de sua atividade. Até o presente momento, são conhecidas poucas CGTases que apresentam estabilidade à altas temperaturas e à baixos valores de pH (NAKAMURA e HORIKOSHI, 1976).

A temperatura é um dos principais fatores que devem ser monitorados durante a produção de CDs. São poucas as CGTases que apresentam alta resistência à 
temperaturas elevadas. Segundo FLASCHEL et al. (1984), o aumento da temperatura promove igualmente o aumento da atividade enzimática, mas é também responsável pelo aumento da velocidade desativação, sendo que a $50^{\circ} \mathrm{C}$ a maioria das CGTases é estável durante 6 horas. A estabilidade térmica da enzima aumenta consideravelmente na presença de amido. FUJIWARA et al. (1992 a) verificaram que a faixa de temperatura de ação das CGTases provenientes de vários mutantes de Bacillus stearothermophilus varia de $55^{\circ} \mathrm{C}$ a $65^{\circ} \mathrm{C}$ e que a termoestabilidade é maior em linhagens selvagens. Em trabalho feito por RAJA e RAMAKRISHNA (1994), visando a otimização das condições para produção de CDs a partir de fécula de mandioca, os autores constataram que a temperatura adequada está em torno de $50-52^{\circ} \mathrm{C}$; o $\mathrm{pH}$ de $6-7$ e a concentração ideal de substrato é $5 \%$.

A estabilidade da CGTase aumenta na presença do amido como substrato (NAKAMURA e HORIKOSHI, 1976; MÄKELÄ et al., 1990; FUJIWARA et al., 1992 b; KIM et al., 1993), o qual parece protegê-la da desnaturação (KIM et al., 1993). O armazenamento da enzima a $-20^{\circ} \mathrm{C}$ é menos favorável que o armazenamento a $4^{\circ} \mathrm{C}$. Segundo FUJIWARA et al. (1992 b), a termoestabilidade da CGTase aumenta com a adição de amido devido à ligação que este substrato faz entre dois sítios da enzima, funcionando assim como uma ponte. $\mathrm{O}$ mesmo não ocorre porém em relação a adição de maltose, pois tal molécula é muito pequena para atuar como ponte neste caso.

Segundo YU et al. (1988), a CGTase adequada para processos industriais deveria ser estável à altas temperaturas e à pHs alcalinos. Esses autores alegam que a reação em pHs alcalinos facilita a agitação e proporciona redução de energia requerida pelo sistema, além de evitar a corrosão de equipamentos.

NOMOTO et al. (1986) constataram que a CGTase proveniente do Bacillus alcalofílico não apresentou inibição de atividade na presença de flouride fenilmetilsulfonil (PMSF), p-cloromercuribenzoato (PCMB) e ácido etilenediaminetetracético (EDTA). NAKAMURA et al. (1993) relataram que a acarbose, formada por anel insaturado, em concentrações maiores que $50 \%$ é inibidor da atividade da CGTase. KIM et al. (1993) constataram que a atividade da CGTase é fortemente 
inibida pela presença de $\beta$-CDs. Concentrações de $6 \mathrm{~g} / \mathrm{l}$ de $\beta$-CDs ocasionaram queda de $50 \%$ de produção. Segundo os autores, a presença de $\alpha$ e $\chi$-CDs resulta em maior inibição de CGTase que a presença de $\beta$-CDs, sendo que $2 \mathrm{~g} / \mathrm{l}$ tanto de $\alpha$ como de $\chi$-CD são suficientes para reduzir $50 \%$ da atividade da enzima. Esses mesmos autores observaram que a atividade de síntese da CGTase para cada CDs é fortemente inibida pela presença da CDs correspondente (KIM et al., 1993). JEANG e LIN (1994) constataram que a CGTase de $B$. macerans é rapidamente inativada a $25^{\circ} \mathrm{C}$ na presença de dietil-pirocarbonato (DEP). Os estudos de cinética da enzima demostraram que o complexo reversível DEP-CGTase não é formado antes do processo de inativação. Os autores observaram que o tratamento do complexo com hidroxilamina $0,1 \mathrm{M}$ resultou em reativação da enzima após 3 horas. A adição de $\alpha, \beta$ e $\chi$-CDs na concentração de $10 \mathrm{mM}$ protegeram a enzima da inativação proporcionada pelo DEP, com porcentagens de preservação de 57, 45 e $63 \%$, respectivamente. No caso da adição de $\alpha$ e $\chi$-CDs nas concentrações de $50 \mathrm{mM}$, a porcentagem de enzima protegida da inativação foi 97 e $92 \%$ para as reações de acoplamento, ciclização e hidrólise.

KIM et al. (1993) verificaram que a atividade da CGTase decresce exponencialmente após 20 horas de reação, sendo que apenas $30 \%$ da atividade é mantida após 60 horas. Tais afirmações levam a deduzir que o decréscimo da taxa de conversão após 20 horas que ocorre durante a produção de CDs é resultante da queda da atividade da CGTase.

\subsubsection{Modo de ação}

Tem sido proposto que a CGTase atua no substrato a partir de extremidades não redutoras (BENDER, $1981 \mathrm{~b}$ ), e ao mesmo tempo ataca as ligações $\alpha-(1,4)$ através de um exo-mecanismo (VETTER e THORN, 1992 b).

Além da reação de ciclização, a CGTase também catalisa reações de acoplamento, responsáveis pela ruptura dos anéis e de transglicolisação (ou desproporcionalização), que realiza a transferência de maltoligossacarídoes lineares 
(NAKAMURA et al., 1993). OHNISHI et al. (1994) atribuem as seguintes reações à CGTase: desproporcionalização, acoplamento e ciclização.

A Figura 10 ilustra a atividade da CGTase.
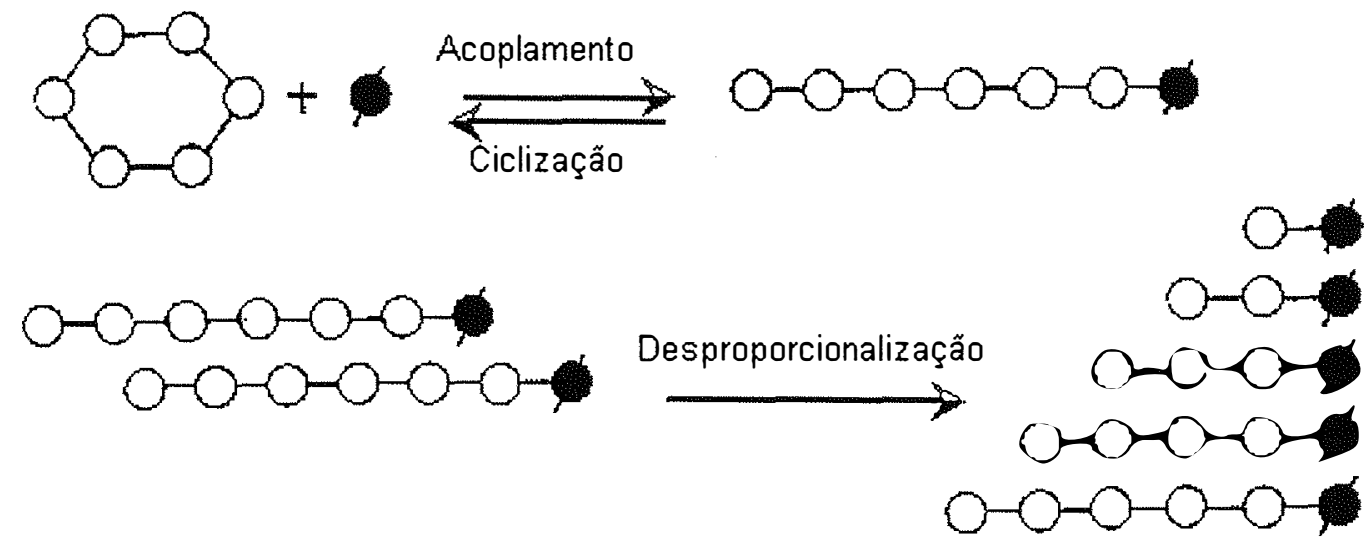

Extremidade redutora
() Unidade de glucopiranose

Fonte: FRIEDMAN (1989)

Figura 10.Reações catalisadas pela CGTase.

A ciclização é a principal reação catalisada pela CGTase (KOBAYASHI et al., 1983). A eficiência da ciclização depende da disponibilidade de aceptores e decresce com aumento da concentração de substrato (BENDER, 1981 b).

A liquefação do substrato promovida pela CGTase ocorre em taxas maiores que a ciclização (BENDER, 1981 a). KOBAYASHI et al. (1983) verificaram que a adição de sódio dodecil sulfato promoveu aumento na atividade de ciclização, porém inibiu a atividade hidrolítica da CGTase. Maltose, maltotriose e maltotetraose podem inibir a reação de ciclização, competindo pelos sítios ativos da enzima. Tal competição foi também observada por maltopentose, maltohexose e maltoheptose, sendo que o grau de inibição é maior quando se trata de moléculas menores como maltotriose e maltotetraose (BENDER, 1985). 
A ciclização é efetuada a partir de extremidades não redutoras utilizando preferencialmente glucanas de C8 e C9 sendo muito lenta em cadeias maiores que C11 (KOBAYASHI et al., 1983). De acordo com OHNISHI et al. (1994), as cadeias curtas de maltoligossacarídeos são adequadas para estudar o mecanismo de ciclização devido à sua simplicidade, quando comparadas as cadeias longas. Segundo BENDER (1981 a), o máximo da taxa de ciclização da CGTase é obtido a partir de cadeias com comprimento equivalente a C16 a C80, indicando a estreita relação entre a ciclização e a conformação em forma de hélice do substrato. Cadeias menores que C14 não podem ser ciclizadas diretamente, e cadeias maiores que C100 são substratos que sofrem pouca ação da enzima. Cadeias longas não são portanto, substratos adequados para ciclização (BENDER, 1981 a).

STARNES (1990) afirma que a presença de maltoligossacarideos e glucose como aceptores favorece a reação de acoplamento. A reação de desproporcionalização ocorre nas primeiras horas de reação, quando o substrato possui cadeias longas, e acredita-se que não afeta a formação de CDs (STARNES, 1990). OHNISHI et al. (1994) afirmam que a CGTase utiliza substratos como C2 e C3 para produzir maltoligossacarídeos maiores do tipo $\mathrm{C} 4, \mathrm{C} 5$ e assim por diante. Esses autores observaram que a velocidade da reação da CGTase pode ser expressa como uma curva exponencial, sendo que a porção linear corresponde ao processo de ciclização e a fase lag é referente ao processo de desproporcionalização.

D-glucose não interfere na ciclização, mas atua como aceptor nas demais reações (BENDER, 1985). BENDER (1985) afirma que a presença de maltoligossacarídeos diminui a produção de CDs, sendo necessário maiores estudos sobre sua interferência durante a reação enzimática com CGTase. VETTER e THORN (1992 a) concluíram que o grau de desproporcionalização aumenta com o aumento da DP (grau de polimerização). Não foram observadas reações com maltose e maltotetraose, mas maltopentose apresentou 50\% de conversão, enquanto dextrinas com DP 13 apresentaram $70 \%$ de conversão. Esses autores também observaram que as ligações entre 
as extremidades redutoras e as subseqüentes unidades de anidroglucose não são atacadas pela CGTase.

$\mathrm{Na}$ reação de transglicosilação, a CGTase transfere os radicais glicosil do amido ou CDs para um aceptor adequado como glucose ou maltose, diminuindo a eficiência da ciclização. Quando as CDs são produzidas, a reação de transglicosilação deveria ser reduzida tanto quanto possível a fim de que a produção de CDs seja maximizada (OKADA et al., 1993 b). Muitos estudos ainda serão necessários para compreender a estrutura catalítica das CGTases, bem como a estabilização da reação de transglicosilação (KLEIN et al., 1992).

Um dos primeiros trabalhos a estudar a reação de acoplamento catalisada pela CGTase foi o de FRENCH et al., em 1954. Esses autores, que denominaram a princípio a CGTase de "amilase" do B. macerans, verificaram que a enzima era capaz de efetuar troca de glicosídeos entre maltose e ciclohexamilose, resultando na formação de sacarídeos de alto peso molecular. Já naquela época esses pesquisadores observaram que mudanças estruturais ou na configuração das unidades de D-glucopiranose retardavam a reação de acoplamento; o que fazia de rafinose, D-manose, D-galactose e D-sorbitol substratos não efetivos para produção de CDs. FRENCH et al. (1954) notaram que a CGTase atuava exclusivamente em ligações de glicosídeos tipo $\alpha-1,4$ e que a reação de acoplamento era catalisada em maior velocidade em $\alpha$ que em $\beta$ ou $\chi$-CD.

Além da concentração da enzima, outro fator que afeta o rendimento da reação de acoplamento é a concentração de $\alpha-C D$. A CGTase do Bacillus macerans reconhece as seis unidades terminais de glucose da extremidade não redutora das $\alpha-(1,4)$-glucanas. $\beta$ e $\chi$-CD não competem porém pela ação de acoplamento e desproporcionalização da CGTase proveniente de Bacillus macerans (VETTER e THORN , 1992 a).

\subsubsection{Aceptores da CGTase}

A maltose atua como aceptor na transglicosilação molecular, acelerando a hidrólise do amido pela CGTase (NAKAMURA et al., 1993). Segundo BENDER (1982), o requerimento de aceptores é o mesmo, tanto para a reação de ciclização, quanto 
para a de hidrólise, indicando uma estreita correlação entre as duas reações. A maltose é mais efetiva que maltotriose enquanto aceptor, sendo que sua adição a $584 \mu \mathrm{m}$ acelerou 2,5 vezes a ciclização e 5,0 vezes a hidrólise (BENDER, 1982).

A CGTase catalisa a transferência do radical glicosil do amido para um aceptor adequado. Os aceptores mais efetivos são aqueles que apresentam configuração similar à da D-glucopiranose, onde o grupo hidroxila é transferido para a posição do $\mathrm{C}_{4}$ (KITAHATA, 1992). Dentre os melhores aceptores, portanto estão a L-glucose, Lxilose, L-sorbose, D-glucose, D-xilose, 6-deoxi-D-glucose, glucopiranosídeos metil- $\alpha$-D e fenil- $\beta-D$, sacarose, melibiose e inusitol. Galactose, manose e lactose não realizam o papel de aceptores de maneira significativa (NORMAN e JØRGENSEN, 1992). Maltose foi o melhor aceptor na reação de acoplamento observada por VETTER e THORN (1992 b). A qualidade do aceptor decresce lentamente de maltose para pentose, mantendo-se constante para dextrinas com DP 11 (VETTER e THORN, 1992 b).

Em trabalho feito por OKADA et al. (1994 b), foi observado que a produção de CDs decresce conforme aumenta a concentração de glucose, de sacarose, de maltose, de maltotriose e de maltotetraose, respectivamente; embora altas concentrações de maltose e maltotriose promovam a produção de $\alpha$-CDs. Tal fato é explicado porque estes oligossacarídeos apresentam o grau de polimerização adequado para produção de $\alpha$ CDs.

Durante as reações de acoplamento e desproporcionalização, parte da cadeia de 1,4- $\alpha$-D-glucopiranosil que contém a extremidade não redutora é transferida do grupo hidroxila do $\mathrm{C}_{1}$ para o grupo hidroxila $\mathrm{C}_{4}$ do aceptor. A reação de acoplamento é um tipo especial de reação de desproporcionalização; na qual a própria extremidade não redutora da cadeia atua como aceptor. Os sítios de ação da enzima não são porém específicos para glucose e maltoligossacarídeos. Metil- $\alpha$-D-glucopiranose, 4-nitrofenil$\alpha$-D-glucopiranose, $\mathrm{D}$-galactose, $\mathrm{L}$-sorbose e $\mathrm{D}$-xilose são citadas como substâncias que atuam como aceptores (BENDER, $1981 \mathrm{~b}$ ). 
Segundo RENDLEMAN (1993), D-glucose inibiu a conversão de maltodextrinas e de xarope de milho em CDs e a presença de maltose resultou em decréscimo da produção de $\chi$-CDs, porém maltotriose não apresentou tal efeito inibidor. Já NIEMANN e SAENGER (1992) observaram que 4-nitrofenil- $\alpha$-maltoligossacarídeos com D.P. 2 a 7 atuam como aceptores, enquanto ciclomaltohexose atua como doador durante a reação catalisada pela CGTase do B. macerans.

VETTER e THORN (1992 b), usando maltose como aceptor da reação de acoplamento com $\alpha$-CDs, verificaram que o máximo da produção da maltooctose; o principal produto da reação com CGTase, representa $45 \%$ do total de substrato convertido e ocorre após 40 minutos. A formação de sacarídeos com DP 14 e 20 ocorre após 90 e 375 minutos de reação, respectivamente. Segundo estes autores, maltose é o melhor aceptor e a sacarose não atua efetivamente enquanto aceptor.

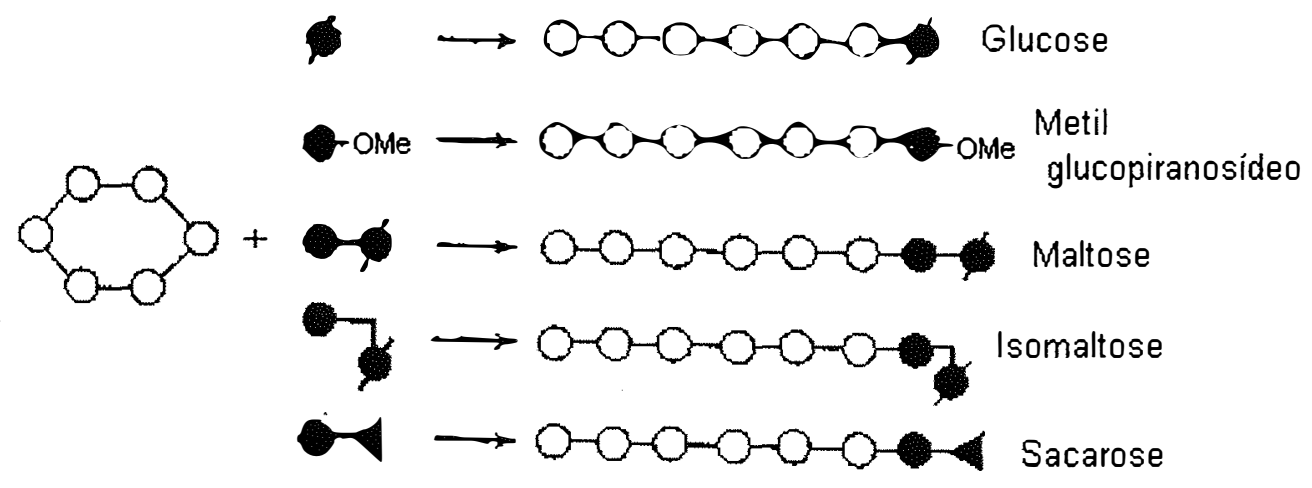

Fonte: FRIEDMAN (1989)

Figura 11.Reação entre CDs e vários aceptores.

TREDER et al. (1989), usando vários polímeros para estudar as reações catalisadas pela CGTase imobilizada, constataram que o 2-nitro-4[N'-(P)carboxidrazina]benzil- $\beta$-glucopiranose e o 2-nitro-4[N'-(P)-carboxidrazina]benzil-4-O$\alpha$-D-glucopiranosil- $\beta$-D-glucopiranose atuam como aceptores, enquanto que o 4- 
metoxicarbonil-2-nitrobenzil 2,3,4,6-tetra-O-acetil- $\beta$-D-glucopiranose e $\quad$ o 4metoxicarbonil-2-nitrobenzil 2,3,4,6-tri-O-acetil-4-O-(2,3,4,6-tetra-O-acetil- $\alpha$-Dglucopiranosil)- $\beta$-D-glucopiranose atuam como doadores na reação de transglicosilação.

É conhecido que a CGTase, quando na presença de aceptores adequados, realiza a reação de transglicosilação intermolecular, reação esta que se caracteriza pela transferência de glicose de CDs ou maltoligossacarídeos para aceptores. Quando Dglucose é usada como aceptor, observa-se a produção de maltose bem como outros maltoligossacarídeos de cadeia linear (KITAHATA et al., 1978).

Segundo KITAHATA et al. (1978), os aceptores, em função de sua potência, são divididos em três grupos: A) onde estão inclusos L-sorbose, D-glucose, D-xilose, 6dioxi-D-glucose e metil e fenil glicosídeos, B) aqueles caracterizados por 2-dioxi-Dglucose e por 3-O-metil-D-glucose e C) composto de açúcares de atuação ineficiente como aceptores como os D-galactose, D-arabinose e D-frutose, D-manose e D-ribose. $\mathrm{Na}$ presença de $\mathrm{D}$-xilose e $\mathrm{D}$-sorbose os resíduos glicosil são preferencialmente transferidos para o $\mathrm{C}_{4}$ do grupo hidroxila da D-xilose e para o $\mathrm{C}_{3}$ do grupo hidroxila da L-sorbose. Mudanças estruturais ou na configuração dos demais átomos de carbono não alteram a eficiência dos açúcares do grupo $\mathrm{A}$, porém modificações de um dos grupos $\mathrm{C}_{2}$, $\mathrm{C}_{3}$ ou $\mathrm{C}_{4}$ causam grandes perdas de eficiência como aceptores (KITAHATA et al., 1978). Tais resultados permitiram que os autores concluíssem que o requisito necessário para que um açúcar seja aceptor da reação de transglicosilação catalisada pela CGTase é a estrutura de piranose com a mesma configuração dos grupo hidroxila dos $C_{2}, C_{3}$ e $C_{4}$, a qual possui a D-glucose.

Foi constatado que a CGTase produzida pelo $B$. megaterium é mais eficiente e mais sensível à presença de aceptores durante a reação de transglicosilação que a CGTase do B. macerans (KITAHATA et al., 1978).

KITAHATA et al. (1992) mensuraram a taxa de transglicosilação intermolecular através da coloração formada entre amido e solução de iodo, baseado no princípio de que a degradação do amido aumenta com a taxa de transglicosilação na presença de 
aceptores. Esses autores verificaram que houve aumento da degradação do amido na presença de aceptores, exceto quando se usou D-ribose. A degradação foi maior no caso da CGTase produzida pelo $B$. stearothermophilus, seguido pela enzima do $B$. megaterium ou do B. macerans. No caso da CGTase produzida pelo B. macerans a degradação do amido foi acelerada em apenas $10 \%$ na presença de D-glucose e Darabinose. D-glucose foi o aceptor mais efetivo para a CGTase do $B$. stearothermophilus, seguido de D-arabinose, L-arabinose, D-galactose, D-manose, Dfrutose, e D-ribose.

$\mathrm{Na}$ ausência de aceptores ou na presença de aceptores de baixa eficiência, a CGTase catalisa principalmente reação de transglicosilação intramolecular e produz CDs. Na presença de aceptores de baixa eficiência como D-arabinose e D-galactose ocorre grande produção de $\alpha$-CDs, principalmente nas primeiras horas de reação. Nesse caso, quando a atividade da CGTase é alta, após um longo tempo de reação as CDs podem atuar como substrato doador para reação de transglicosilação intermolecular (KITAHATA et al., 1992).

KITAHATA e OKADA (1974) estudaram a reação de transglicosilação da CGTase e verificaram que o requerimento para aceptor é que a estrutura da piranose tenha a mesma configuração da D-glucopiranose.

Há também trabalhos que usam 2-nitro-4-(N-carboxiamido)-benzil- $\beta$-Dglucopiranosideo, metil $\alpha$ e $\beta$-glucopiranosídeo e p-aminofenil $\beta$-d-glucopiranosídeo como aceptores durante a reação de transglicosilação (ZEHAVI et al., 1992).

\subsubsection{Similaridade entre CGTases e $\alpha$-amilases}

Aparentemente há grande similaridade entre CGTase e $\alpha$-amilases. A maioria das CGTases possui aproximadamente 686 aminoácidos, enquanto a maior parte da $\alpha$ amilases possui cerca de 500 aminoácidos, sendo que as seqüências similares entre estas enzimas é menor que 30\% (NAKAMURA et al., 1992; NAKAMURA et al., 1993; VETTER e THORN, 1992 a). A CGTase apresenta duas regiões, as quais são atribuídas as principais características da enzima; uma possui uma extremidade com o radical - 
$\mathrm{COOH}$ e a outra possui extremidade com $-\mathrm{NH}_{2}$. A região terminal-COOH da CGTase contem 200 aminoácidos a mais que a região terminal- $\mathrm{NH}_{2}$ da $\alpha$-amilase (FUJIWARA et al., 1992 b). NAKAMURA et al. (1993), verificaram que a CGTase proveniente de Bacillus sp. possui entre 680-609 aminoácidos.

Segundo VETTER e THORN (1992 a), a CGTase é uma enzima monomérica com peso molecular em torno de $74,5 \mathrm{kD}$, sendo que sua cristalografia obtida por raio-X e sua seqüência de aminoácidos revelam grande similaridade com a estrutura das $\alpha$ amilases. $\alpha$-amilase e CGTase promovem a quebra de ligações glicosídicas tipo $\alpha-1,4$ de amilose e amilopectina e sabe-se que tais enzimas possuem certa similaridade em seus sítios ativos (Fig.12) (FUJIWARA et al., 1992 b). NAKAMURA et al. (1992) sugerem que a ação da CGTase se faz por mecanismo semelhante ao das $\alpha$-amilases. Esses autores citam ainda vários trabalhos que sugerem que este mecanismo também foi reconhecido em pululanases e isoamilases, concluindo que essas enzimas apresentam mecanismo de hidrólise semelhante. Segundo NAKAMURA et al. (1993), foram identificados três resíduos de histidina como sítios ativos (His-140, His-233 e His-327) tanto nas $\alpha$-amilases como nas CGTases. 


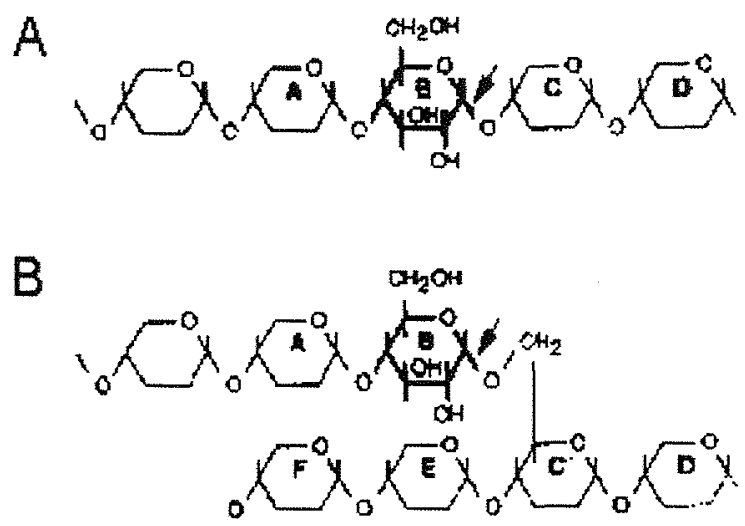

$\longrightarrow$ ligações hidrolisadas CGTases.

A - Segmentos lineares de glucanas com ligações $\alpha-1,4$, que são substratos de $\alpha$-amilases e

B - Segmentos ramificados de glucanas, os quais são substratos de enzimas desramificantes.

Fonte: Mac GREGOR (1993)

Figura 12. Modelo de ação das enzimas $\alpha$-amilases e CGTases e seus respectivos pontos de hidrólise.

FUJIWARA et al. (1992 b) afirmam que o terminal- $\mathrm{NH}_{2}$ presente na CGTase apresenta estrutura similar à da taka-amilase, mas o terminal- $\mathrm{COOH}$ é característica única da CGTase. Alguns autores sugerem que a região terminal- $\mathrm{COOH}$ é responsável pela ciclização de maltoligossacarídeos lineares, mas trabalhos recentes como o de FUJIWARA et al. (1992 b) constataram grande importância da região do terminal-NH2 na reação de ciclização. Discordando de FUJIWARA et al. (1992 b), KIMURA et al. (1989) relatam que a região terminal- $\mathrm{COOH}$ possui homologia com o sítio da amiloglucosidase que se liga ao amido, sugerindo que esta região está envolvida na ciclização dos oligossacarídeos lineares.

KLEIN et al. (1992) consideram a homologia existente entre $\alpha$-amilases e CGTases e suas similaridades estruturais e, sugerem que o sítio ativo da CGTase é formado por sete subsítios. Segundo MacGREGOR (1993), as diferenças destas enzimas 
no metabolismo do amido estáo ligadas aos diferentes números de subsítios que compõem os sítios ativos

A $\alpha$-amilase do $B$. megaterium, difere da maioria das outras $\alpha$-amilases por catalisar reações de transglicosilação de maneira semelhante às CGTases (BRUMM et al., 1991). BRUMM et al. (1991) constataram que glucose e glucosídeos atuam como aceptores moleculares durante a reação de transferase realizada pela $\alpha$-amilase proveniente de $B$. megaterium. Nesse caso, maltose também atua como aceptor na reação de transglicosilação quando em baixas concentrações e como inibidor da hidrólise do amido quando em altas concentrações, provavelmente devido à competição pelo sítio ativo da enzima. A reação de transferase da $\alpha$-amilase produz oligossacarídeos com baixo grau de polimerização (DP2, DP3 e DP4), indicando que esta enzima proporciona múltipla hidrólise, o que a difere das CGTases conhecidas (BRUMM et al., 1991). Baseados nestes resultados, os autores sugerem que a $\alpha$-amilase do $B$. megaterium deve ser um híbrido de dois tipos de enzima, a $\alpha$-amilase e a CGTase.

\subsubsection{Estrutura molecular das CGTases}

Muitos estudos têm sido feitos visando a caracterização da estrutura molecular das CGTases. HELLMAM et al. (1990) observaram que CGTase proveniente de mutantes com deleções de 36 e 84 aminoácidos da região terminal-COOH produziram quantidades relativamente maiores de $\chi$-CDs quando comparada com CGTase do tipo selvagem.

FUJIWARA et al. (1992 b) sugerem que a região de terminal- $\mathrm{NH}_{2}$ da CGTase é responsável pela hidrólise das ligações $\alpha-1,4$ do amido. KIMURA et al. (1990) sugerem que a CGTase possui dois sítios ativos; um localizado perto do terminal- $\mathrm{NH}_{2}$, o qual é responsável pela hidrólise do amido e o outro localizado próximo à região do terminal$\mathrm{COOH}$ que catalisa a formação de CDs. Para fazer tal afirmação, estes autores se baseiam no fato de que, apesar da maioria das $\alpha$-amilases possuírem cerca de 500 aminoácidos e as CGTases cerca de 700 aminoácidos, ambas enzimas apresentam o 
mesmo terminal- $\mathrm{NH}_{2}$. KIMURA et al. (1989) obtiveram mutantes de Bacillus sp. \#1011 através da deleção de parte da região terminal-COOH da CGTase e verificaram que a enzima produzida pelo mutante degradou amido à glucose, maltoligossacarídeos, $\alpha$ e $\beta$-CDs, porém sua estabilidade ao $\mathrm{pH}$ foi reduzida. HELLMAM et al. (1990) obtiveram mutantes de Bacillus circulans usando E. coli como vetor, os quais produziam CGTases que apresentavam deleções de 36, 84, 125 e 225 aminoácidos da região do terminal$\mathrm{COOH}$. Observaram que, tanto a atividade amilolítica como a formadora de $\beta$-CDs das CGTases obtidas a partir dos mutantes, foi cerca de $0,5 \%$ da atividade da CGTase obtida a partir da linhagem de $B$. circulans selvagem. Esses autores também constataram que apenas cerca de 84 aminoácidos do terminal- $\mathrm{COOH}$ não participam do sítio catalítico da enzima e discordam da hipótese de KIMURA et al. (1990), afirmando que pequenas deleções do terminal- $\mathrm{COOH}$ afetam drasticamente a atividade amilolítica da enzima. KANEKO et al. (1989) relatam que dos 720 aminoácidos que constituem a CGTase de Bacillus, a perda de apenas 30 aminoácidos da região terminal- $\mathrm{COOH}$ é suficiente para que ocorra perda de atividade enzimática. HELLMAM et al. (1990) citam ainda uma teoria, na qual propõem que a região da enzima que apresenta o terminal- $\mathrm{COOH}$ seria responsável pela afinidade com o substrato, uma vez que esta apresenta homologia com a região das amiloglucosidases, a qual possui o sítio de afinidade com amido. Já para KANEKO et al. (1989) tanto a região terminal-COOH como a terminal- $\mathrm{NH}_{2}$ apresentam grande influência na especificidade da enzima.

KANEKO et al. (1990 b) sugerem que a inserção de certos segmentos na seqüência dos genes responsáveis pela sintese de CGTase pode, juntamente com os terminais $-\mathrm{NH}_{2}$ e $-\mathrm{COOH}$, apresentar resistência à hidrólise de $\alpha-\mathrm{CD}$. A região terminal- $\mathrm{NH}_{2}$ pode ainda apresentar diferentes funções no mecanismo de ação e na determinação de características das CGTases (KANEKO et al., 1990 b). KANEKO et al. (1989) comparando as propriedades de CGTases provenientes de Bacillus e CGTases quiméricas, constataram que a região terminal- $\mathrm{NH}_{2}$ é responsável pela estabilidade térmica da enzima. Já se tratando de $\mathrm{pH}$ ótimo, tanto a região terminal- $\mathrm{NH}_{2}$ como a - 
COOH são de grande influência. KANEKO et al. (1990 a) indicam que, nas duas CGTases estudadas (CGTase 17-1 e CGTase 38-2), nas sete primeiras horas de reação há tendência crescente em relação a produção de CDs; após 12 horas de reação a produção estabiliza-se atingindo um patamar. A tabela 7 ilustra os resultados obtidos por estes autores.

Tabela 7. Comparação entre a atividade das CGTases quiméricas 17-1 e 38-2, construídas por KANEKO et al. (1990 a).

\begin{tabular}{ccc}
\hline Característica & CGTase 17-1 & CGTase 38-2 \\
\hline Aminoácidos & 713 & 712 \\
Peso molecular & 74.140 & 75.160 \\
Termoestabilidade & $53^{\circ} \mathrm{C}$ & $65^{\circ} \mathrm{C}$ \\
pH ótimo & 6,0 & $6,0-9,0$ \\
\hline
\end{tabular}

Fonte: KANEKO et al. (1990 a)

Segundo OHNISHI et al. (1992), a CGTase apresenta quatro moléculas de triptofano. Os autores usaram N-bromosuccinamida (NBS) em substituição à tais moléculas e observaram que a modificação resulta na perda da atividade de hidrólise para formação de $\alpha$-CDs, mas não afeta a atividade de ciclização. Tais resultados sugerem que um dos quatro resíduos de triptofano está localizado no sítio ativo que desempenha papel decisivo na atividade de hidrólise da enzima, estando intimamente ligado com a hidrólise de $\alpha$-CDs (OHNISHI et al., 1992). KIMURA et al. (1990) pesquisaram vários promotores da CGTase de Bacillus e verificaram que o promotor trp é mais efetivo na expressão das características da enzima, sendo que os mutantes portadores deste promotor apresentaram produção enzimática 5,5 vezes maior quando comparada com as linhagens selvagens.

NAKAMURA et al. (1994) descreveram quatro resíduos aromáticos denominados Phe-183, Phe-259, Phe-283 e Tyr-195, localizados em centros ativos da CGTase do Bacillus sp. 1011, os quais não estão presentes nas $\alpha$-amilases. A substituição de apenas um destes resíduos aromáticos (Tyr-195) por leucina provocou aumento drástico na produção de $\chi$-CDs e praticamente anulou a produção de $\alpha$-CDs. 
Esses autores sugerem que os resíduos Phe-183 e Phe-259 estão envolvidos nas reações com aceptores e que desempenham papel decisivo na ciclização (NAKAMURA et al., 1994). JEANG e LIN (1994) afirmam que a modificação de um resíduo de histidina da CGTase proveniente do B. macerans não causou perda de atividade enzimática e que há quatro resíduos de histidina fundamentais para a atividade da enzima. Esses autores ainda afirmam que dois destes resíduos devem ser responsáveis pela atividade enzimática referente ao acoplamento, ciclização e desproporcionalização. Segundo NAKAMURA et al. (1993), foram identificados três resíduos de histidina como sítios ativos (His-140, His-233 e His-327) tanto nas $\alpha$-amilases como nas CGTases. Os autores substituíram os resíduos de histidina por arginina e observaram que a formação de $\beta$ CDs e a atividade de acoplamento e hidrólise foram fortemente afetadas, além de ocorrer alteração da faixa de $\mathrm{pH}$ de atuação da enzima e redução da atividade. A substituição também aumentou a energia de ativação requerida para a formação de $\alpha$-CD e, apesar da reação de ciclização não ser afetada houve alteração na proporção de $\alpha: \beta: \chi-C D$. A quantidade de $\beta$-CDs formada foi reduzida de 2 a 10 vezes. Alguns trabalhos afirmam ainda que apenas um dos resíduos de histidina é importante para a reação de ciclização. O decréscimo da atividade da pululanase e a mudança da proporção dos produtos finais obtidos com a substituição de resíduos de histidina sugerem que a catálise da maioria das enzimas amilolíticas e da CGTase é similar (NAKAMURA et al., 1993).

Segundo ABE et al. (1991), a hidrólise do amido promovida pela CGTase é muito pequena quando comparada a reação de transglicosilação. Esses autores consideraram que a CGTase possui vários subsítios, sendo que o sítio catalítico está localizado entre os subsítios de maneira semelhante à taka-amilase. Os subsítios $\mathrm{S}_{1}$ e $\mathrm{S}_{1}{ }^{\prime}$ seriam responsáveis pela hidrólise das ligações $\alpha-1,4$ glicosídicas do substrato, sendo considerados os mais importantes para ação da CGTase.

SIN et al. (1994) construíram mutantes de B. ohbensis a fim de melhor estudar o mecanismo de ação de sua CGTase. Foi feita substituição do aminoácido Tyr-188 e os autores verificaram que este corresponde ao aminoácido Phe-191 da CGTase do $B$. 
stearothermophilus, observado-se que ocorria $60 \%$ de homologia entre as seqüências destas CGTases. Concluíram que o fato da CGTase do B. stearothermophilus ser produtora de $\alpha-\mathrm{CD}$ e a CGTase do $B$. ohbensis produtora de $\chi-\mathrm{CD}$, provavelmente se deve às diferenças de tais aminoácidos, os quais devem determinar o tamanho da cavidade das CDs. No mesmo trabalho também foi observado que a CGTase do $B$. ohbensis tem as estruturas da região terminal- $\mathrm{NH}_{2}$ similares às da taka-amilase.

\subsubsection{Fontes produtoras de CGTase}

Durante 70 anos foi atribuído apenas ao Bacillus macerans, a capacidade de produzir CGTase (BENDER, 1981 b). Sabe-se hoje que as principais fontes de CGTases são bactérias, sendo que a maior parte são Bacillus alcalofilicos ou neutrofilicos (MÄKELÄ et al., 1990).

As condições exigidas para reação, como eficiência de conversão e proporção de CDs produzidas, estão diretamente relacionada ao microorganismo produtor da CGTase. NOMOTO et al. (1986) isolaram uma linhagem de Bacillus alcalofilico do solo de que produz grande quantidade de CGTase no meio de cultura e apresenta peso molecular de 68.000, com pH ótimo entre 6,5 e 8,0 e estabilidade entre pH 6,0 e 11,0. NIELSEN (1991) relata que o tempo de reação com CGTase proveniente de Thermoanaerobacter sp. (3-6 horas) é menor que o tempo requerido pela CGTase do B. macerans (1-3 dias). KITAHATA et al. (1992) observaram que a CGTase produzida pelo B. macerans produz principalmente $\alpha$ e $\beta$-CDs, sendo menos sensível a aceptores que a CGTase sintetizada pelo $B$. stearothermophilus.

Diferentes tipos de CDs são obtidas através de diferentes CGTases provenientes de Bacillus. A CGTase proveniente de Bacillus macerans IOF3490 produz $\alpha$-CD como produto principal da reação de hidrólise do amido, enquanto CGTases produzidas por $B$. megaterium e $B$. circulans possibilitam a obtenção de $\beta$-CDs e a produzida pelo Bacillus stearothermophilus produz $\alpha$ e $\beta$-CDs, considerada intermediária entre os dois tipos anteriores (FUJIWARA et al., 1992 a). No caso da produção de $\alpha$-CDs a partir de amido 
hidrolisado, a CGTase do B. macerans é a mais usada. Já para a produção predominante de $\beta$ e $\chi$-CDs a CGTase de Bacillus alcalofilicos é a mais indicada (KANEKO et al., 1990 c). KANEKO et al. (1990 c) verificaram a produção de CDs a partir de CGTases provenientes de três linhagens diferentes de Bacillus (Bacillus linhagem A-147, B. macerans, e Bacillus sp. alcalofílico) e constataram que a CGTase proveniente do $B$. macerans converteu cerca de $35 \%$ do amido em CDs após 50 horas de incubação, dos quais $71 \%$ foi $\alpha$-CDs. Já a CGTase produzida pela linhagem A-147 atuou sobre maltoligossacarídeos maiores que maltotriose, produzindo pequenas quantidades de CDs, em uma proporção de 2,0:2,6:1,0 de $\alpha: \beta: \chi-C D s$, respectivamente. A CGTase do Bacillus alcalofilico hidrolisou 33\% do amido inicial, onde $71 \%$ foi convertido em $\beta$ CDs. No mesmo trabalho foi avaliada a ação simultânea de duas das três CGTases (CGTase linhagem A-147 + CGTase do Bacillus alcalofilico e CGTase linhagem A147 + CGTase do B.macerans). A produção de $\alpha$-CDs variou de $4,5 \%$ a $71 \%$, a de $\beta$ CDs de 25 a $71 \%$ e a de $\chi$-CDs se manteve praticamente constante, entre 16 e $23 \%$. Esses autores ainda sugerem que a mistura de duas CGTases com ação simultânea é adequada para produção das três CDs. SATO et al. (1985) observaram que o pH ótimo da CGTase do B. ohbensis é de 5,5.

A proporção $\alpha: \beta: \chi-C D$ também é alterada pela fonte produtora da enzima. Segundo MÄKELÄ et al. (1990), as CGTases produzidas por bactérias neutrofilicas sintetizam principalmente $\alpha$-CDs, enquanto CGTases de bactérias alcalofilicas produzem preferencialmente $\beta$-CDs. LEE et al. (1992) isolaram um microorganismo capaz de produzir uma CGTase extracelular e o identificaram como Klebsiella oxytoca 19-1. Amilopectina e amido solúvel foram as fontes de carbono que proporcionaram maior produção de CDs, enquanto que não se observou atividade da CGTase quando mono e dissacarídeos como glucose, lactose, sacarose e maltose foram usados como fonte de carbono. $\mathrm{O} \mathrm{pH}$ ótimo foi 6,0, sendo que em $\mathrm{pH}$ abaixo de 4,0 e acima de 10,0 não foi observada atividade enzimática. A temperatura ótima desta CGTase foi $40^{\circ} \mathrm{C}$. Foi observado máximo de atividade enzimática após 9 horas de incubação, sendo que após 19 horas praticamente não houve aumento da produção de $\alpha$-CDs. Quando se usou 
amilose, pululana ou maltoligossacarídeos como substrato não foi observada síntese de CDs. Segundo os autores, a característica mais importante desta enzima foi a alta produção de $\alpha$-CDs, em curto tempo de reação, sem a adição de solventes ou detergentes (surfatantes), com uma proporção de 96,5:3,5:0,0 de $\alpha: \beta: \chi$-CDs respectivamente. KIMURA et al. (1987) clonaram o gene responsável pela produção de $\beta$-CDs da CGTase do Bacillus sp. \# 1011, com o objetivo de estudar a estrutura e o mecanismo de ação da enzima e visando obter uma CGTase com alta produção de $\beta$-CDs a nível industrial. Foi observado que mais de $95 \%$ da enzima produzida pelo mutante e pela linhagem parental foi excretada no meio de cultura, enquanto $70 \%$ da enzima produzida pelo vetor genético Escherichia coli foi excretada no meio. A análise em HPLC revelou a proporção de 1,0:8,8:0,05 de $\alpha: \beta: \chi$-CDs. Alguns autores como GEORGANTA et al. (1991), usaram E. coli como vetor do gene responsável pela produção de CGTase em linhagens de Bacillus e obtiveram mutantes que excretavam no meio $70 \%$ do total da enzima produzida.

KITAHATA e OKADA (1974) relataram que a CGTase proveniente do Bacillus megaterium produziu uma maior quantidade de $\beta-\mathrm{CD}$, enquanto a CGTase do $B$. macerans produziu preferencialmente $\alpha$-CD. A proporção de $\alpha, \beta$ e $\chi$-CD com a enzima do $B$. megaterium foi de $1,0: 1,8: 0,8$, e a obtida pela enzima do $B$. macerans foi de 2,7:1,0:0,5. O oligossacarídeo produzido em maior quantidade pela CGTase do $B$. megaterium foi maltose, seguido de glucose e outros oligossacarídeos maiores. Já a enzima produzida pelo $B$. macerans possibilitou maior produção de maltotriose, vindo a seguir maltose e glucose (KITAHATA e OKADA, 1974). A CGTase do B. ohbensis é usada para produção comercial de $\beta$ e $\chi$-CD e produz cerca de $40 \%$ de $\beta$-CD e $8 \%$ de $\chi$ CDs (SIN et al., 1994).

SABIONI e PARK (1992) avaliaram uma CGTase produzida pelo Bacillus lentus, que apresentava $\mathrm{pH}$ ótimo de $6,5-8,5$ e temperatura máxima de $45-55^{\circ} \mathrm{C}$. Segundo estes autores, a enzima aumenta consideravelmente sua estabilidade térmica se houver adição de íons de cálcio e sua conversão máxima é de $65 \%$, sendo que após 24 horas de reação apresenta a proporção de 1,0:67,0:1,6 para $\alpha, \beta$ e $\chi$-CD, respectivamente. 
A tabela 8 exemplifica algumas CGTase de diferentes fontes e suas condições ótimas de reação para produção de CDs.

Tabela 8. Proporções de CDs produzidas pelas CGTases de diferentes microorganismos.

\begin{tabular}{cccc}
\hline Microorganismo & $\mathrm{pH}$ ótimo & $\begin{array}{c}\text { Temperatura } \\
\text { ótima }\end{array}$ & Proporção $\alpha: \beta: \chi-\mathrm{CD}$ \\
\hline Bacillus sp. (alcalofilico) & $4,5-9,0$ & $45^{\circ} \mathrm{C}$ & $1,0: 11,0: 1,5$ \\
B. megaterium & $5,0-5,7$ & $55^{\circ} \mathrm{C}$ & $1,0: 2,4: 1,0$ \\
B. macerans & $5,0-5,7$ & $55^{\circ} \mathrm{C}$ & $2,7: 1,0: 1,0$ \\
B. ohbensis & 5,5 & - & - \\
B. circulans & 5,5 & $60^{\circ} \mathrm{C}$ & $1,0: 10,5: 0,0$ \\
B. amyloliquefaciens & $4,0-7,0$ & $70^{\circ} \mathrm{C}$ & principalmente $\beta-\mathrm{CD}$ \\
B. stearothermophilus & 6,0 & $70^{\circ} \mathrm{C}$ & $\alpha-\beta$ \\
B. subtilis & 8,0 & $75^{\circ} \mathrm{C}$ & $\chi$ \\
Klebsiellapneumoniae & 6,9 & $40^{\circ} \mathrm{C}$ & $1,0: 1,8: 0,5$ \\
B. lentus & $6,5-7,5$ & $55^{\circ} \mathrm{C}$ & $1,0: 67,0: 1,6$ \\
\hline
\end{tabular}

Fonte: NORMAN e JØRGENSEN (1992)

\subsubsection{Determinação da atividade da CGTase}

De acordo com SATO et al. (1985), uma unidade de CGTase é definida como sendo a quantidade de enzima necessária para formar $1 \mu \mathrm{mol}$ de $\mathrm{CD} /$ minuto $(\beta-\mathrm{CD}$ ou $\alpha-C D$, em função da enzima), a partir de amido solúvel.

O calor é o processo mais comumente citado na literatura para inativar a enzima em estudos sobres a cinética da CGTase. HAYASHIDA e KAWAKAMI (1992) inativaram a CGTase do B. macerans e B. ohbensis através da imersão do material em banho-maria fervente durante 10 minutos. SAKAI et al. (1991) desativou a CGTase proveniente de $B$. stearothermophilus pela imersão do material em banho-maria fervente durante 10 minutos.

Segundo BENDER (1981 b), é difícil estabelecer uma metodologia ideal para medir a atividade da CGTase. Tal dificuldade provavelmente se deve ao fato da enzima catalisar diferentes reações simultaneamente, por isso diferentes métodos são usados para se determinar a atividade da CGTase. A falta de uma metodologia tem sido o principal obstáculo para um completo entendimento da estrutura química desta enzima. 
Em função disto, tanto o mecanismo de ação, como a estrutura da CGTase, são assuntos pouco esclarecidos, necessitando de maiores estudos (BENDER, 1981 b). MÄKELÄ et al. (1988) atribuem os diferentes relatos de pH ótimo da CGTase proveniente do Bacillus alcalofílico as falhas de metodologia da mensuração da atividade da enzima.

Inicialmente foram empregados métodos não específicos como coloração por iodo e mensuração indireta através da quantificação de glucose e açúcares redutores produzidos na etapa de desproporcionalização (BENDER, 1981 a). O trabalho feito por BENDER (1981 a) foi pioneiro no desenvolvimento de metodologia específica para mensurar a atividade de ciclização da $\alpha$-CGTase. Nesse método colorimétrico a leitura do complexo formado por $\alpha-C D / i o d o$ é feita a $290 \mathrm{~nm}$. Segundo BENDER (1981 a), o complexo formado entre solução de iodo e $\alpha-C D$ apresenta absorção característica em luz ultravioleta, mostrando forte afinidade entre a molécula de $\mathrm{CD}$ e a molécula de iodo. O principal inconveniente da determinação da atividade da CGTase através de colorimetria por iodo é que o amido, principal substrato usado para produção de CDs, também forma complexo com iodo, ocasionando grande interferência na leitura. A atividade hidrolítica e de ciclização não podem, portanto, ser mensuradas separadamente pois o iodo servirá de indicativo tanto para amido não hidrolisado como para $\alpha$-CDs. KIM et al. (1993) e GEORGANTA et al. (1991) mensuraram a atividade da CGTase através do método colorimétrico (NAKAMURA e HORIKOSHI, 1976) que emprega iodo com o objetivo de corar o amido não dextrinizado.

KOBAYASHI et al.(1983) determinaram a atividade hidrolítica da CGTase através da mensuração de açúcares redutores usando o método de Somogy-Nelson. Muitos trabalhos porém, empregam ácido 3,5 dinitrossalicílico para medir a quantidade de açúcares redutores formada durante a reação catalisada pela CGTase (MATTSSON et al., 1991; LEE e KIM, 1992; MÄKEL $\ddot{A}$ et al., 1988; NAKAMURA e HORIKOSHI, 1977; PODKOVYROV e ZEIKUS, 1992; TREDER et al., 1989). Esse método também é muito usado por para mensurar a atividade hidrolítica das $\alpha$-amilases (IVONY et al., 1983). 
O método usado por SABIONI e PARK (1992) para avaliar a atividade enzimática da CGTase do Bacillus lentus foi proposto por NOMOTO et al. (1986) e baseia-se na precipitação de complexos formados entre CDs e tricloroetileno. Métodos colorimétricos para quantificar a produção de $\beta$-CD se baseiam na habilidade desta $C D$ em formar complexo com fenolftaleína. Gama-CD tem sido quantificada através da formação do complexo com verde de bromocresol. LEJEUNE et al. (1989) definiram metodologia específica, através da formação de complexos de inclusão entre $\alpha$-CDs e metil orange em condições de $\mathrm{pH} 1,2$ a $16^{\circ} \mathrm{C}$, com leitura feita em comprimento de onda de $505 \mathrm{~nm}$. Segundo esses autores, a especificidade do método é grande, sendo limitada pela interferência de maltoligossacarídeos, $\beta$ e $\chi$-CDs, os quais causam variações de $16 \mathrm{e}$ $5 \%$, respectivamente, pois também formam complexos com o corante em questão. Outra limitação deste método é que a formação do complexo $\alpha-\mathrm{CD} /$ metil orange é altamente influenciada pela temperatura. Por tal razão, este método não pode ser empregado com a mesma precisão em determinações de CGTases que atuam em altas temperaturas, como a do B. macerans, com temperatura ótima entre 50 e $55^{\circ} \mathrm{C}$ e, nestas condições a leitura deve ser feita a $546 \mathrm{~nm}$. MÄKELÄ et al. (1988) avaliaram a atividade de ciclização da CGTase através do método que emprega maltose-metilorange.

PARK et al. (1989) desenvolveram metodologia baseada na incubação de microorganismos produtores de CGTase em meio sólido contendo amido solúvel, polipeptona, extrato de levedura, fenolftaleína e metil orange. As CDs formam complexos de inclusão com fenolftaleína, mudando a coloração do meio através da formação de halos amarelos. O metil orange foi usado para possibilitar a detecção de halos decorrentes da produção de ácidos, de coloração vermelha, tornando-os distintos dos halos formados pela atividade da CGTase. Estes autores também observaram que a intensidade da coloração amarela foi maior para $\beta$ e $\chi$-CDs, e que $\alpha$-CDs formaram halos de coloração menos intensa. PARK et al. (1989) afirmam também que o diâmetro dos halos formados é proporcional a quantidade de CDs sintetizadas, sendo os resultados confirmados com análises em HPLC. 


\subsubsection{Imobilização da CGTase}

O trabalho feito por NAKAMURA e HORIKOSHI (1977) foi um dos pioneiros na imobilização de CGTase e usava para isso resina de troca iônica. A enzima imobilizada teve temperatura ótima deslocada de 50 para $55^{\circ} \mathrm{C}$, com maior estabilidade à pH ácido. A perda de atividade da enzima solúvel foi muito maior, enquanto a atividade da CGTase imobilizada foi preservada durante mais de 2 semanas em condições de reação.

IVONY et al. (1983) constataram que a imobilização da CGTase produzida por B. macerans com polímero Akrilex $\mathrm{C}$ resulta em deslocamento do $\mathrm{pH}$ ótimo da enzima de 5,9 para 5,5. A faixa de temperatura ótima de atividade da enzima também é modificada; ficando próxima a $40^{\circ} \mathrm{C}$, enquanto a CGTase imobilizada varia de $40^{\circ} \mathrm{C}$ a $60^{\circ} \mathrm{C}$. A enzima imobilizada também mostrou maior estabilidade térmica e de $\mathrm{pH}$, quando comparada à dispersa (IVONY et al., 1983).

Em trabalho feito por SAKAI et al. (1991), o pH ótimo da CGTase imobilizada em resina FE-4611 variou de 6,0 a 8,0, enquanto o pH ótimo da enzima não imobilizada foi 6,0. A temperatura ótima da enzima imobilizada foi ligeiramente inferior a da enzima não imobilizada.

YANG e SU (1989), imobilizaram CGTase usando quitosana e verificaram que o $\mathrm{pH}$ ótimo da enzima imobilizada foi de 8,5 , enquanto da enzima dispersa foi de 8,0 . Nesse caso, a atividade da CGTase imobilizada foi maximizada em temperaturas superiores a $60^{\circ} \mathrm{C}$ enquanto que a CGTase dispersa a $55^{\circ} \mathrm{C}$. A estabilidade do $\mathrm{pH}$ porém não foi alterada, mas a CGTase imobilizada apresentou maior estabilidade térmica que a CGTase dispersa. Os valores de $\mathrm{K}_{m}$ da CGTase imobilizada também foram maiores. Esses mesmos autores realizaram trabalhos em escala piloto com CGTase e $\alpha$-amilase imobilizadas com resultados satisfatórios (SU e YANG, 1990).

Segundo GOTTVALDOVA et al. (1988), os métodos de isolamento das CGTases como precipitação não específica usando acetona ou sulfato de amônio e os métodos de troca iônica com cátions como Sephadex são os mais usados. Esses autores ainda afirmam que o rendimento da purificação em métodos de precipitação não é 
satisfatório, havendo necessidade de elevado número de repetições. GOTTVALDOVA et al. (1988) descrevem um método de bioadsorção específica da CGTase usando amido de milho modificado, gelatinizado e armazenado a $-20^{\circ} \mathrm{C}$, e afirmam que suas principais vantagens são a simplicidade, a absorção altamente específica e a alta eficiência na recuperação da enzima.

LÁSZLÓ et al. (1981) separaram CGTase do B. macerans de outras enzimas hidrolíticas através de afinidade cromatográfica, usando gel composto por Sepharose 6B complexado com $\alpha$-CDs, obtendo 90-92\% de pureza. MÄKELÄ et al. (1990) obtiveram $90 \%$ de pureza usando gel hidrofóbico de fenol-Sepharose em CGTase proveniente do Bacillus alcalofîlico.

A imobilização de enzimas através de uso de membranas capilares possui como principal vantagem a não alteração da estrutura química da enzima, podendo ser operada nas mesmas condições de pressão, temperatura e pH, além de proporcionar aumento de produtividade devido à maior probabilidade de contato entre enzima e substrato (OKADA et al., 1994 a). Neste mesmo trabalho, os autores observaram aumento de $10 \%$ a $20 \%$ da produção de CDs com CGTase imobilizada e que, neste caso, ocorre decréscimo da proporção $\alpha / \beta-C D$. Observaram que houve conversão de $\alpha$-CDs em $\beta$ CDs e maltoligossacarídeos e vice-versa quando se trabalha com a enzima imobilizada e que a conversão de oligossacarídeos (DP 2 a 6) em CDs foi em torno de 70\%. A adição de glucose, maltose e sacarose atuando como aceptores, em substrato contendo CDs, acelerou a degradação de CDs quando comparado com substrato sem a adição de aceptores (OKADA et al., 1994 a).

\subsection{Substratos usados para produzir CDs}

\subsubsection{Matéria prima para produção de CDs}

A produção de CDs através dos métodos convencionais torna alto seu custo, restringindo sua aplicação industrial. A maioria dos trabalhos e das pesquisas que visam 
aumento da produtividade de CDs são voltadas para melhoramento genético e obtenção de linhagens de microorganismos produtores de CGTase (LEE e KIM, 1992).

Segundo FLASCHEL et al. (1984) a escolha do substrato para produção de CDs depende principalmente do preço. Fermentações que usam substratos sólidos tem sido muito empregadas em escala industrial nos últimos anos, pois possuem como principal vantagem a simplicidade de manuseio (RAMAKRISHNA et al., 1994).

Segundo BENDER (1981 b), no caso de CDs, a fécula de batata, por apresentar relativa solubilidade em água, é substrato mais viável economicamente que o amido de milho, o qual só é solubilizado em água quente após ser dissolvido em sulfohidroxi dimetil. MATTSSON et al. (1991) observaram que o amido de arroz é um substrato pobre para a produção de CDs. SAKAI et al. (1991) usaram amido de milho ceroso com DE inferior a 2 como substrato de reação de 24 horas com CGTase e obtiveram mistura de dextrinas ramificadas e CDs na proporção de 1:1. De acordo com RAJA et al. (1990), batata e milho são as fontes de matéria prima mais usadas para produção de CDs, sendo que a batata doce também é esporadicamente empregada. Segundo RAJA e RAMAKRISHNA (1994), a mandioca é um excelente substrato para produção de CDs devido à facilidade de liquefação da fécula. Esses mesmos autores ainda ressaltam que apenas a fécula de batata é mais suscetível à liquefação que a fécula de mandioca. Porém MATTSSON et al. (1991) não observaram diferenças de resposta à adição de etanol quando usaram substratos provenientes de várias fontes como batata, milho, trigo e arroz. Neste trabalho, a proporção de produtos obtidos nos diferentes substratos também foi a mesma.

$\mathrm{O}$ uso de diferentes meios de cultura para o crescimento de microorganismos produtores de CGTase tem sido pouco estudados. RAMAKRISHNA et al. (1994) empregaram farelo de trigo a 10\% como substrato para produção de CGTase, usando Bacillus cereus como produtor da enzima. Neste caso, a atividade máxima da enzima foi observada em 24 horas de fermentação, seguido de decréscimo, que foi atribuído à presença de protease obtida durante a fermentação. Esses autores obtiveram aumento de atividade enzimática em 2,7 vezes quando compararam o farelo de trigo com meio de 
nutrientes usados na fermentação e sugerem que o farelo de trigo é um substrato promissor para produção de CGTase em larga escala.

\subsubsection{Influência da estrutura do substrato na produção de CDs}

Apesar das marcantes diferenças estruturais entre a amilopectina de milho e a de batata, as condições de ação da CGTase são similares em ambos os substratos (BENDER et al., 1982). Em trabalho feito com CGTase provenientes de diferentes mutantes de Bacillus stearothermophilus, observou-se que estas apresentavam diferentes afinidades para o substrato em questão (FUJIWARA et al., 1992 a). KOBAYASHI et al. (1983) afirmam que a ação da CGTase depende não apenas da especificidade da enzima, mas também da conformação do substrato, a qual pode ser modificada com a complexação de agentes com estrutura em forma de hélice. NAKAMURA et al. (1993) usaram amido e amilose pura como substrato para reação com CGTase oriunda de mutantes de Bacillus e verificaram que a eficiência da ciclização depende da estrutura do substrato.

De acordo com BENDER (1989), após 48 horas de digestão a $42^{\circ} \mathrm{C}$ com CGTase proveniente de Klebsiella pneumoniae, 49,4\% da amilopectina de mandioca hidrolisada foi classificada como não cíclica; sendo $3,5 \%$ da amilopectina hidrolisada a maltotetraose e glucose, indicando que as reações de acoplamento e desproporcionalização da enzima foram insignificantes no final da reação. A diferença, cerca de $59,4 \%$ do amido de mandioca foi convertido em CDs, onde a proporção de $\alpha, \beta$ e $\chi$-CDs foi respectivamente de 1,0:10,6:3,9. Neste mesmo trabalho, observou-se que os menores sacarídeos ramificados foram resíduos de D-glucose. As dextrinas lineares obtidas desta reação foram divididas em quatro frações de diferentes tamanhos, todas suscetíveis ao ataque de $\beta$-amilase, indicando que a CGTase deixa grandes partes da cadeia de amilopectina sem serem hidrolisadas. BENDER (1989) ainda observou que os fragmentos de dextrinas $\beta$-limites de amilopectina de milho, mandioca e batata apresentaram grandes similaridades, indicando que as amilopectinas possuem semelhança estrutural entre si. 
BENDER (1989) estudando a estrutura de amilopectina, concluiu que há relações estruturais entre amilopectina de mandioca e de milho. Segundo BENDER (1981 b), tanto as cadeias tipo-A como as tipo-B, no modelo estrutural de amilopectina proposto por French (1973), podem sofrer ciclização e desproporcionalização. A reação inicial de hidrólise observada nas cadeias de amilose e a formação de dextrinas limites também ocorrem nas cadeias de amilopectina. Após a desramificação, os fragmentos das cadeias tipo-B parecem se constituir em substrato preferencial da CGTase durante a reação de hidrólise (BENDER et al., 1982). A estrutura do substrato também pode afetar a interação dos sítios enzimáticos responsáveis pela hidrólise (OHNISHI et al., 1992).

BENDER et al. (1982) afirmam que o pico de produção de $\alpha$-CD coincide com a rápida retrogradação das cadeias menores de amilose. Segundo BENDER (1982), tanto a reação de ciclização quanto a de hidrólise parecem depender diretamente das regiões helicoidais do substrato.

Foi constatado que a CGTase proveniente de B. stearothermophilus utiliza maltose (G2) (OHNISHI et al., 1994 b) e maltotriose (G3) (OHNISHI et al., 1994 a) como substratos para produção de CDs, sendo que o principal produto é $\beta$-CD. Tanto a maltose como a maltotriose participam diretamente da reação de desproporcionalização, sendo seguida da reação de ciclização (OHNISHI et al., 1994 a; OHNISHI et al., 1994 b). Já BENDER (1982) afirma que a ação dos aceptores decresce quando eles são usados como substrato durante a reação e que, maltose é um substrato pouco utilizado pela CGTase.

\subsubsection{Concentração do substrato}

Enquanto a proporção de $\alpha: \beta: \chi-C D s$ varia em função do microorganismo produtor da CGTase, a quantidade de CDs produzidas é alterada pela concentração inicial de amido e pelo condições de reação (RAJA e RAMAKRISHNA, 1994).

Segundo STARNES (1990), além de $\mathrm{pH}$, temperatura, tempo de reação, dosagem da enzima e presença de complexantes, fatores como tipo, concentração e tratamento prévio do amido também afetam a produção de CDs. KIM et al. (1993) trabalharam com 
substratos de concentrações de 5, 7 e 10\% de amido, e observaram que houve decréscimo da taxa de conversão com o aumento da concentração de amido. Estes autores obtiveram 2,9 g de CDs após 48 horas de reação, com concentração inicial de amido de 7\%, usando ultrafiltração em sistema de reator de membrana. Neste caso o amido de milho usado como substrato foi triturado com pérolas de vidro visando aumentar a ação da CGTase sobre o grânulo.

NAKAMURA e HORIKOSHI (1976) verificaram que cerca de $85-90 \%$ de amilose, $75-80 \%$ de fécula de batata, $65-70 \%$ de amilopectina, 55-60\% de glicogênio, $45-50 \%$ de dextrinas $\beta$-limites, $20-25 \%$ de maltotriose e $10-15 \%$ de maltose foram convertidas em CDs após 5 horas de reação em solução contendo $1 \%$ de cada substrato. Os autores também afirmam que após 60 minutos de incubação $25-30 \%$ do amido foi convertido em CDs e que a concentração e a natureza do substrato alteram consideravelmente tais valores, sendo que concentrações de amido menores que $5 \%$ e ausência de aceptores da reação de transferência como maltose e glucose propiciam acréscimo da produção de CDs. HAYASHIDA e KAWAKAMI (1992) usaram concentração de $50 \mathrm{~g} / \mathrm{l}$ de amido solúvel como substrato para produzir CDs a partir de CGTase de $B$. macerans a $50-60^{\circ} \mathrm{C}$ com $\mathrm{pH}$ entre 5,0 e 6,0. De acordo com TSUCHIYAMA et al. (1991 b), a eficiência de conversão de $\alpha$-CD decresce consideravelmente com o aumento da concentração de amido e com tempo prolongado de reação.

Segundo MATTSSON et al. (1991), a produção de CDs geralmente decresce consideravelmente com elevadas concentrações de substrato, porém tal fato pode ser contornado com a adição de etanol durante a reação, o que possibilita alta produtividade mesmo com concentrações de substrato de 30\%. Esses autores afirmam ainda que o aumento de produção decorrente da adição do etanol é acentuado quando se usa altas concentrações de substrato. Segundo BENDER (1981), independente da concentração inicial do substrato, o máximo que se pode obter a partir de cadeias com DP 16 são concentrações de $\alpha-\mathrm{CD}$ de $20 \mathrm{mM}$. 
Alguns autores propõem que a velocidade da reação depende da concentração do substrato (OHNISHI et al., 1994 b). No caso de amidos de baixo peso molecular, as concentrações de substratos podem ser aumentadas sem que ocorra aumento da viscosidade, considerado inconveniente no manuseio e na operação dos equipamentos. Com fécula de batata a concentração está limitada a 100g/l (FLASCHEL et al., 1984).

NIELSEN (1991) relata que nas suspensões com concentrações de 1-5\% de amido, mais de $70 \%$ do substrato é convertido em CDs, nas proporções de $34 \%$ de $\alpha$, $24 \%$ de $\beta$ e $12 \%$ de $\chi$-CDs. SAKAI et al. (1991) constataram que quanto maior a concentração de substrato, menor a quantidade de CDs ramificadas produzidas ao longo da reação.

OKADA et al. (1994 a) afirmam que a reação de acoplamento é acompanhada pela conversão de $\alpha-C D$ em $\beta-C D$ e vice-versa e que a proporção maltoligossacarídeo/açúcares e $\alpha / \beta$-CDs são bons indicadores para avaliar a velocidade da reação de acoplamento. Neste mesmo trabalho, estes autores também observaram que a velocidade da reação de acoplamento é acelerada tanto pela quantidade excessiva de CGTase como pelo longo tempo de reação. RENDLEMAN (1992) usando dodecanona para complexar CDs durante a reação, verificou que, nas primeiras horas de reação, a velocidade da produção de $\beta$-CDs foi maior que de $\chi$-CDs, mas que com o passar do tempo de reação a produção de $\beta$-CDs diminuiu e a de $\chi$-CDs aumentou, sugerindo que nas últimas horas de reação ocorre formação de $\chi$-CDs a partir de $\beta$-CDs. Para reações incubadas com CGTase proveniente de B. macerans, HAYASHIDA e KAWAKAMI (1992) observaram produção crescente de $\alpha$-CDs nas primeiras 25 horas de reação, sendo que o decréscimo de $\alpha$-CDs foi acompanhado do aumento da concentração de $\beta$ CDs, mas não foi obtido mais que $10 \%$ de $\chi$-CDs. Esses autores sugerem que há uma estreita relação entre o aumento da concentração de $\beta$-CDs e a diminuição de $\alpha$-CDs.

Já para BENDER (1981 b), apenas o tempo de incubação determina qual será o tipo de CD predominante e, que após longo período de incubação, a maioria de $\alpha$-CDs podem ser convertidas em $\beta$-CDs. Após certo tempo de reação, a quantidade de $\alpha$-CDs formada decresce devido ao fato destas serem transformadas em $\beta$-CDs (MATTSSON et 
al., 1991). Segundo RENDLEMAN (1993), $\chi$-CD é a que apresenta menor produção, com porcentagem de amido convertido entre 4 e $7 \%$, enquanto que a produção de $\alpha$ e $\beta$ CDs oscila entre 35 e $50 \%$. Entretanto estas proporções relativas podem variar consideravelmente de acordo com as condições de reação (RENDLEMAN, 1993).

\subsection{Produção de CDs}

\subsubsection{Produção industrial de CDs}

A produção de CDs compreende basicamente as seguintes etapas: seleção e cultivo de microorganismo produtor da enzima, separação, concentração e purificação da CGTase, conversão enzimática do amido pré hidrolisado em CDs e separação, purificação e cristalização das CDs.

Concentração da enzima e do substrato, condições do meio de reação e presença de agentes complexantes são alguns dos fatores monitorados durante produção de CDs em escala industrial. Agentes complexantes podem ou não serem usados para otimizar a produção de CDs. Em muitos casos, o uso de complexantes apresenta sérios problemas em relação à toxicidade das CDs produzidas. A separação das CDs é, porém uma das etapas mais onerosas da produção. A concentração de maltose e glucose presentes no meio não deve exceder $5 \%$ para que não ocorra inibição da produção. O uso de enzimas desramificantes é tido como alternativa para melhorar a taxa de conversão (SZEJTLI, 1990). Segundo TSUCHIYAMA et al. (1991 a), entre os principais problemas da produção industrial está a remoção de CDs durante a reação, visando evitar que sua concentração no meio provoque decréscimo da produção. Outro problema citado por estes autores é a separação das CDs e dos produtos secundários após a reação. Resina de troca iônica e solventes orgânicos são atualmente os métodos mais empregados na separação de CDs (TSUCHIYAMA et al., 1991 a). A precipitação de complexos de inclusão e adsorção específica de CDs por polímeros sintéticos e afinidade cromatográfica também são usados (TSUCHIYAMA et al., 1991 b). A membrana apresenta como principal obstáculo à separação de CDs a viscosidade quando a 
concentração de substrato é alta (SU e YANG, 1990). HASHIMOTO et al. (1988) empregaram processo de separação contínua de $\alpha-C D$ e glucose em 12 colunas de adsorção empacotadas com íon de sódio. Esses autores afirmam que o resultado é satisfatório e que a recuperação de $\alpha-\mathrm{CD}$ é alta.

$\mathrm{O}$ acúmulo de CDs durante a reação é característico de sistema de produção industrial por batelada. TSUCHIYAMA et al. (1991 b) desenvolveram um processo de produção de $\alpha$-CDs usando reator com sistema de remoção contínua de $\alpha$-CDs. Esses autores obtiveram o dobro da produção de $\alpha$-CDs por este sistema quando o compararam com o sistema tradicional de produção por batelada (DELBURG, 1991).

No processo de produção controlada, apenas um tipo de CDs é sintetizado. Este processo é usado na Hungria para produção de $\beta$-CDs. $\mathrm{O} \mathrm{pH}$ da suspensão de amido a $33 \%$ (p/v) é ajustado a 6,2, seguido da adição de ácido clorídrico ou $\alpha$-amilase para hidrólise. A suspensão é então aquecida a $80^{\circ} \mathrm{C}$ e o amido é parcialmente hidrolisado. A elevação da temperatura a $120^{\circ} \mathrm{C}$ durante 30 minutos permite que a enzima seja desativada e que o amido solubilize. Em seguida há adição de CGTase e de tolueno a 5\% e a reação é incubada a $45^{\circ} \mathrm{C}$ por 105 horas sob forte agitação. A separação de $\beta$-CD é feita por filtração e o tolueno é recuperado por destilação. A pureza de $\beta-C D$ produzida por este método é cerca de $99,7 \%$ e a conversão do amido é próxima a $33 \%$ (DELBURG, 1991).

Já no processo de produção não controlado, há produção das três CDs. Este processo é empregado no Japão para produção de $\beta$-CDs. A concentração de amido usada é de $15 \%$ e sua liquefação é feita a $80^{\circ} \mathrm{C}$ durante 20 minutos através da adição de CGTase alcalina. $\mathrm{O}$ pH é de 8,5 . Em seguida há resfriamento a $60^{\circ} \mathrm{C}$ e a reação é incubada durante 30 horas. A desativação da enzima é feita com elevação da temperatura a $100-120^{\circ} \mathrm{C}$, com ajuste de $\mathrm{pH}$ a 5,5. $\alpha$-amilase bacteriana é então adicionada com o objetivo de hidrolisar o amido não convertido em CDs. A coloração do meio é removida através de carbono ativo. A filtração é feita em gel com resinas específicas de adsorção. 
TSUCHIYAMA et al., (1991 a) selecionaram adsorventes específicos de $\alpha$ e $\beta$ CDs para produção de CDs. Segundo estes autores, ácido esteárico foi mais efetivo para $\alpha-C D$, enquanto ciclohexanepropinamida-n-ácido capróico foi melhor para $\beta-C D$.

\subsubsection{Liquefação prévia do amido}

O primeiro passo na produção das CDs é a liquefação do amido, que geralmente é feita com o uso de ácidos ou através de reações enzimáticas realizadas à altas temperaturas. Alguns trabalhos porém não consideram a liquefação como uma etapa obrigatoriamente separada, alegando que pode ser feita simultaneamente à reação de produção das CDs. A pré hidrólise do amido aumenta a solubilidade e diminui a viscosidade de suspensões altamente concentradas (STARNES, 1990). Ainda segundo STARNES (1990), o equilíbrio da reação entre ciclização e desproporcionalização é obtido quando ocorre o término da liquefação do amido.

LEE e KIM (1992) empregaram amido de milho não liqüefeito na concentração de 15\% (peso/volume) com 500 unidades/g de CGTase para produção de CDs em biorreator. Em trabalho feito por KIM et al. (1993), foram produzidas CDs a partir de amido de milho não liqüefeito em um biorreator no qual a hidrólise do amido e a produção de $\mathrm{CDs}$ ocorrem simultaneamente. Estes autores verificaram que a produção de CDs nestas condições foi similar à produção feita a partir de amido previamente liqüefeito com enzima. Segundo NORMAN e JØRGENSEN (1992), as condições de liquefação tais como baixas concentrações de enzima, baixos valores de $\mathrm{pH}$ e altas temperaturas durante a dextrinização diminuem consideravelmente a formação de CDs. De acordo com LEE e KIM (1992), em nível industrial, a produtividade de CDs obtidas a partir de amido de milho sem prévia liquefação não apresenta diferença quando comparada à produção através de amido liqüefeito. Além disso, o consumo de energia de produção com liquefação é maior quando esta etapa é realizada separadamente (LEE e KIM, 1992), sendo portanto indesejável que a liquefação consista em uma fase isolada do processo. 
Segundo KIM et al. (1993), a CGTase não hidrolisa ligações glicosídicas tipo $\alpha$ 1,6 presentes na amilopectina e sofre inibição da atividade de acoplamento na presença de açúcares redutores, principalmente maltose. Assim, no caso de alta concentração de amilopectina, espera-se que ocorra diferença no rendimento de produção quando se usa amido liqüefeito ou não como substrato. Logo, é esperado que a adição de enzimas desramificantes como a pululanase ou isoamilase aumente o rendimento de produção (KIM et al., 1993). NAKAMURA e HORIKOSHI (1977) observaram conversão de 85$90 \%$ de amilose e $60-65 \%$ de amilopectina, sugerindo assim que se fossem empregadas enzimas desramificantes a produção de CDs seria maior. Estes autores porém obtiveram conversão de $53 \%$ do amido em CDs com CGTase dispersa e imobilizada na presença de enzimas desramificantes. Estes valores reduziram para $49 \%$ e $46 \%$, respectivamente na ausência de tais enzimas. O principal obstáculo na utilização de pululanases e isoamilases na produção de CDs é que a faixa de $\mathrm{pH}$ na qual estas enzimas trabalham não é compatível com a faixa de $\mathrm{pH}$ da CGTase e da estabilidade das reações de ciclização e acoplamento.

TREDER et al. (1989) empregaram como substrato para produção de CDs suspensão a $5 \%$ de amido de batata liqüefeito a $80-85^{\circ} \mathrm{C}$ durante 40 minutos, com $\mathrm{DE}$ em torno de 0,37 . Foi também observado que retrogradação pode diminuir a produção de CDs (STARNES, 1990).

A liquefação do amido para a produção de CDs pode ser feita de maneira convencional, através do uso de $\alpha$-amilase. Tal método porém apresenta como principal inconveniente a baixa produção de CDs, uma vez que ocorre a formação de grande quantidade de maltodextrinas e oligossacarídeos que atuam como aceptores da transglicolisação intermolecular e da ciclização. Por esta razão, é interessante, do ponto de vista industrial, que a liquefação do amido seja feita usando CGTase. NAKAMURA e HORIKOSHI (1977) obtiveram uma redução de $31 \%$ na produção de CDs obtidas a partir de amido liqüefeito com $\alpha$-amilase quando comparadas à liquefação feita com CGTase. 
NIELSEN (1991) afirma que algumas CGTases, como a do Bacillus macerans, não possuem capacidade de liqüefazer o amido à altas temperaturas, sendo que o amido previamente hidrolisado deve ser acrescentado à enzima no momento da produção de CDs, visto que implica em aumento de custos.

A maioria das CGTases não apresentam termoestabilidade à temperatura de liquefação do amido. Assim, um dos principais fatores que encarecem a produção de CDs é a liquefação prévia com $\alpha$-amilase. Após a liquefação, a $\alpha$-amilase deve ser inativada para que se adicione a CGTase, elevando os custos de produção. Assim sendo, liquefação prévia do amido deve ser evitada quando o objetivo é produção de CDs (STARNES, 1990). Um dos primeiros trabalhos que relatam CGTase termoestáveis foi o de YU et al. (1988). Esses autores verificaram que o B. amyloliquefaciens da linhagem AL35 produz uma CGTase extracelular termoestável que apresenta o máximo de atividade após 12-16 horas do início da fermentação, em temperatura ótima de $70^{\circ} \mathrm{C}$ e $\mathrm{pH}$ ótimo entre 4.0-7.0. Segundo YU et al. (1988) esta enzima apresenta grande termoestabilidade com perda de atividade menor que 5\% após 15 minutos de incubação a $60^{\circ} \mathrm{C}$, na ausência da estabilizadores como cálcio. A enzima também apresenta estabilidade em $\mathrm{pH}$ alcalino, com perda de atividade inferior a 5\% após ser incubada durante duas horas em meio de $\mathrm{pH}$ 8.0-10.0 (YU et al., 1988). No mesmo trabalho, os autores constataram que a CGTase produziu preferencialmente $\alpha$-CDs; cerca de $95 \%$ do total de CDs produzidas. Não se observou produção significativa de $\chi$-CD.

Estudos com CGTase proveniente de Thermoanaerobacter sp. têm sido conduzidos, objetivando produzir uma enzima com maior resistência às temperaturas elevadas que as CGTases oriundas das espécies de Bacillus (STARNES, 1990). NORMAN e JØRGENSEN (1992) isolaram uma linhagem de Thermoanaerobacter sp. produtora de CGTase (EC 3.2.1.19), que apresentou como principal característica grande termoestabilidade, apresentando temperatura ótima de atividade entre $90-95^{\circ} \mathrm{C}$ e pH ótimo em torno de 6.0, sendo que na presença de amido a enzima é estável a temperaturas superiores a $100^{\circ} \mathrm{C}$. Ainda segundo estes autores, outra característica desta enzima é sua grande capacidade de liquefação do amido, possibilitando que em $\mathrm{pH}$ 
próximo a 4,5, na ausência de cálcio, usando baixas concentrações de substrato, através do processo "jet cooker" $\left(105^{\circ} \mathrm{C}\right.$ por 5 minutos seguidos de $90-95^{\circ} \mathrm{C}$ por 90 minutos) é possível liqüefazer até $35 \%$ do total de amido. Esta enzima ainda apresenta mais de $80 \%$ de atividade na faixa de $\mathrm{pH}$ 5,0-6,7.

De acordo com NORMAN e JØRGENSEN (1992), a CGTase ideal seria aquela que apresentasse grande estabilidade às condições normais de liquefação comercial com temperaturas acima de $100^{\circ} \mathrm{C}$ e baixo $\mathrm{pH}$, sem formar grande quantidade de produtos secundários e corantes. Esses mesmos autores estudaram diferentes formas de liquefação: com $\alpha$-amilase a pH 6,0 e com CGTase variando o $\mathrm{pH}$ de 4,0 a 5,0. A CGTase apresentou instabilidade em pH 4,0. Com pH 4,5 e 5,0, a liquefação do amido foi satisfatória, apresentando boa separação da fração lipoproteica. A tabela 9 mostra os resultados obtidos por NORMAN e JØRGENSEN (1992) quando se compara a liquefação do amido feita com $\alpha$-amilase de Bacillus licheniformis e com CGTase proveniente de Thermoanaerobacter $\mathrm{sp}$. em diferentes $\mathrm{pHs}$.

Tabela 9. Efeito do pH na liquefação do amido.

\begin{tabular}{cccccc}
\hline Enzima & $\begin{array}{c}\text { pH de } \\
\text { liquefação }\end{array}$ & D.P.1 (\%) & D.P.2(\%) & D.P.3(\%) & D.P.4 (\%) \\
\hline$\alpha$-amilase & 6,0 & 95,6 & 3,3 & 0,3 & 0,8 \\
& 5,0 & 95,0 & 3,8 & 0,5 & 0,7 \\
\hline CGTase & 4,5 & 95,6 & 3,3 & 0,3 & 0,8 \\
& 4,0 & 95,4 & 3,3 & 0,3 & 1,0 \\
\hline
\end{tabular}

* D.P. : grau de polimerização

Fonte: NORMAN e JØRGENSEN (1992)

Conforme se observa na tabela 9, praticamente não houve diferença entre as duas enzimas quanto à liquefação. Estes autores usaram um sistema de liquefação denominada "jet cooker", no qual o amido umedecido é colocado a $105^{\circ} \mathrm{C}$ com injeção direta de vapor durante 5 minutos, sob pressão. A suspensão é transferida para recipientes com agitação constante, à pressão atmosférica em banho com temperatura de $95^{\circ} \mathrm{C}$ durante 90 minutos. $\mathrm{O}$ substrato é então resfriado a $60^{\circ} \mathrm{C}$ e sacarificado com 
glucoamilase de Aspergillus niger. Segundo estes autores, a etapa de resfriamento consiste na fase crítica do processo, uma vez que é então observado que a suspensão adquire aspecto leitoso e pode ocorrer precipitação se não houver agitação suficiente. Provavelmente os autores estão se referindo ao processo de gomificação do amido seguido da tendência à retrogradação.

Outro fator que deve ser avaliado é o valor da dextrose equivalente (DE) do amido liqüefeito. RAJA e RAMAKRISHNA (1994) e obtiveram 20-28\% de conversão do substrato em CDs com liquefação prévia da suspensão de amido em solução de cloreto de cálcio, usando $\alpha$-amilase, resultando num hidrolisado com DE inferior a 2 . Segundo FLASCHEL et al. (1984), o aumento considerável da DE promove queda na velocidade da reação.

\subsubsection{Uso de aditivos durante a produção de CDs}

É conhecido o aumento da produção de CDs através da adição de álcoois e surfatantes (HAYASHIDA e KAWAKAMI, 1992). O uso de solventes orgânicos como tolueno, decanol, etanol e propanol aumenta consideravelmente a produção de CDs, porém as CDs obtidas com tais solventes não podem ser empregadas em alimentos, drogas ou cosméticos (LEE e KIM, 1992).

Um dos aditivos mais usados é o etanol. Segundo SAKAI et al. (1991), o efeito da adição do etanol na produção de CDs ramificadas deveria ser considerado como uma das principais medidas para reduzir os custos. A adição de dodecanol provoca um deslocamento do equilíbrio da reação promovida pela CGTase, aumentado em mais de 50\% a produção de CDs (FLASCHEL et al., 1984). SAKAI et al. (1991) observaram que a quantidade de CDs ramificadas aumentou $3 \%$ quando foi acrescido $30 \%$ de etanol à reação e $4,5 \%$ quando $60 \%$ de etanol foi adicionado. TREDER et al. (1989) constataram aumento de 46 para $58 \%$ na produção de CDs através da adição de etanol. HAYASHIDA E KAWAKAMI (1992) observaram um acréscimo de 1,5 a 2,0 vezes na produção de CDs quanto se adicionou à reação polietileno glicol (PEG 400) ou polipropileno glicol (PPG 425). Esses autores atribuem esses resultados à mudança na 
conformação do substrato e à redução da atividade de hidrólise da enzima ocasionada por tais álcoois. Segundo MATTSSON et al. (1991), o uso de dodecanol aumenta apenas a produção de $\alpha$-CDs. Estes autores observaram que mediante a adição de $15 \%$ de etanol em reação usando concentração de $15 \%$ de substrato, a produção de $\beta$-CDs aumentou de $19 \%$ para $46 \%$ e a de $\chi$-CDs praticamente dobrou, enquanto a de $\alpha$-CDs apresentou decréscimo. Resultados semelhantes foram notados com a adição de 10\% de sulfoxidimetil, sendo que neste caso a produção de $\chi$-CDs permaneceu a mesma. MATTSSON et al. (1991) ainda ressaltam que o efeito do etanol é mais acentuado quando se usa altas concentrações de substrato. Etanol acrescido em concentrações superiores a $20 \%$ ou sulfoxidimetil em concentrações acima de $30 \%$ propiciaram decréscimo considerável na produção de CDs, provavelmente devido à desnaturação enzimática. Quando se adiciona etanol na reação, a taxa de conversão de amilose em CDs é de $47 \%$, praticamente a mesma que a da amilopectina, com 45\% (MATTSSON et al., 1991).

LEE e KIM (1992) obtiveram aumento de 13 a $40 \%$ na produção de CDs acrescendo $10 \%$ de isopropanol, $5 \%$ de butanol-3 ou $10 \%$ de etanol, sendo que os maiores acréscimos foram notados com butanol-3. Na presença de butanol-1 e butanol-2 porém houve decréscimo de 66 e 20\% na produção, respectivamente. Na ausência de tais solventes observou-se rápido aumento na produção de CDs durante as 10 primeiras horas de reação seguido de estabilização. Quando os solventes foram usados a produção de CDs foi crescente mesmo após 10 horas de reação. O uso de solventes não alterou a proporção de $\alpha: \beta: \chi$-CDs obtidas ao longo da reação. A atividade de hidrólise da enzima também não foi afetada pela adição dos solventes orgânicos. Uma das hipóteses para explicar tal aumento de produção é que ocorre redução da inibição da atividade da CGTase devido à precipitação das CDs, decorrente da adição de solventes. Outra hipótese é que a inibição da enzima pelo produto final (CDs) seja atenuada pela formação do complexo solvente/CDs (LEE e KIM, 1991). MATTSSON et al. (1991) discordam desta teoria, alegando que solventes de estruturas distintas, como etanol e sulfoxidimetil, deveriam apresentar diferenças básicas na produção de $\mathrm{CDs}$, o que não 
ocorreu nos resultados obtidos por estes autores. Sugerem que tal aumento de produtividade é devido ao decréscimo da atividade água na reação e chamam a atenção para a inibição da atividade de hidrólise da CGTase, quando em presença de etanol.

$\mathrm{Na}$ Europa, mais de $90 \%$ das CDs são produzidas usando solventes para complexação durante a reação. O uso de dodecanol precipita complexo formado pela $\alpha$ CD, possibilitando conversão de $25 \%$ e purificação de $93 \%$. Cicloctanato forma complexos com $\beta-C D$, com taxas semelhantes de conversão e purificação (STARNES, 1990).

Surfatantes como lauril sulfato de sódio (SDS) e fenil polioxietileno isoctil (Triton) aumentam a atividade da CGTase, sendo efetivos na produção de $\alpha$ e $\beta$-CDs e CDs ramificadas (KOBAYASHI et al., 1983). Esse autores observaram que amido solúvel acrescido de $10 \%$ de SDS propiciou um aumento de 1,6 vezes na produção de $\alpha$ $\mathrm{CDs}$, além de formar vários tipos de CDs ramificadas. A adição de surfatantes como o SDS altera portanto a estrutura do substrato, sendo efetivo na formação de hélices, favorecendo o aumento da taxa de ciclização. O SDS porém, inibe a atividade hidrolítica devido à dificuldade da enzima em atacar partes helicoidais do substrato que estão emaranhadas com SDS (KOBAYASHI et al., 1983). RENDLEMAN (1992) obteve aumento da produção de $\chi$-CDs através da adição de ciclodecanona, ciclodecanol, ciclododecanometanol, éter ciclododecil metil e ciclododecano de 50, 32, 26 e 17\%, respectivamente. Segundo este autor, a adição de SDS, propicia aumento da produção de CDs, com pequenas quantidades de CDs ramificadas. Neste trabalho, o autor afirma que a adição de ciclododeceno e de $\mathrm{N}$-ciclododecilacetamina não aumenta a produção de $\chi$ $\mathrm{CD}$, provavelmente devido à instabilidade do complexos formados. Acréscimo de ciclododecanona em xarope de milho (DE 25 ) proporcionou conversão de $28 \%$ de $\chi$ CDs. Ciclotridecanona foi menos efetivo para produção de $\chi$-CDs (14\%), enquanto que complexantes cíclicos com mais de 13 e menos de 12 átomos no anel não são eficientes para aumento da produção de $\chi$-CDs (RENDLEMAN, 1993).

Surfatantes que apresentam cadeias lineares com extremidades hidrofóbicas são efetivos para aumentar a produção de $\alpha-C D$, enquanto surfatantes que possuem 
estruturas cíclicas nas extremidades hidrofóbicas são mais efetivos para aumentar a produção de $\beta$-CD (KOBAYASHI et al., 1983). Alguns trabalhos citam o uso de óleos vegetais para complexar CDs formadas durante a reação e assim deslocar o equilíbrio, aumentando a produtividade (MATTSSON et al., 1991).

FRENCH et al. (1954) notaram que a $\alpha-C D$ formada na fase inicial da reação era convertida em $\beta$-CD quando na presença de precipitantes como tolueno ou tricloretileno.

\subsubsection{Purificação de CDs}

Alfa e $\chi$-CDs são purificadas através de separação por cromatografia, sendo este um dos principais componentes de seu custo. Com o objetivo de aumentar a solubilidade das CDs, o dodecanol tem sido empregado para facilitar a precipitação (FLASCHEL et al., 1984).

Métodos convencionais de purificação de CDs comumente usam solventes orgânicos perigosos à saúde, tais como tricloroetileno, tetracloetileno, bromobenzeno e tolueno (YAMAMOTO e HORIKOSHI, 1981).

YAMAMOTO e HORIKOSHI (1981) compararam vários polímeros sintéticos na purificação de $\alpha$-CDs, como os de troca catiônica Amberlite IR-120 B, 120 AG, Diaion WK-11, PK-212L, SK 104S; os de troca aniônica Amberlite IRA-68, IRA-93, IRA-400, IRA-402, IRA-410, IRA-900, IRA-910, IRC-50, Diaion WA-11, WA-20, WA-30, Duolite A-4 e os de adsorção Amberlite XAD-2, XAD-4, XAD-7, Diaion HP10, HP-20, Hokuetsu KS, AF, L-1 e HS. Esses autores constataram que os polímeros Amberlite XAD-2 e XAD-4 adsorvem melhor $\alpha$-CDs, que de acordo com análise em HPLC, apresentaram pureza em torno de $88,9 \%$ de $\alpha$-CDs. No mesmo trabalho foi observado que, para o polímero Amberlite XAD-4, a taxa de adsorção de $\alpha$-CDs foi a praticamente a mesma entre a temperatura de 0 e $60^{\circ} \mathrm{C}$ da coluna e que acima de $60^{\circ} \mathrm{C}$ houve decréscimo na taxa de adsorção.

A ultrafiltração em reator de membrana foi usada por KIM et al. (1993) com o objetivo de aumentar a produção de CDs através da redução da inibição da atividade da CGTase pela presença de CDs. Foi observado que usando ultrafiltração a produção de 
CDs após 48 horas de reação foi maior que 55\%, enquanto que sem ultrafiltração a produção não ultrapassou $35 \%$ após 48 horas e 15\% após 24 horas. A proporção de $\alpha: \beta: \chi-C D$ também foi alterada pela ultrafiltração, uma vez que usando reator de membrana a proporção foi de 0,7:7,5:1,8 e no sistema convencional foi de 1,7:6,6:1,7. Nota-se portanto maior produção de $\beta$-CDs quando se aplica ultrafiltração. Além disso, o sistema de reator de membrana apresenta a vantagem da redução da quantidade de enzima usada, visto que em sistema contínuo de produção foram necessárias 1.420 unidades de CGTase para produzir $1 \mathrm{~g}$ de CDs em 48 horas, enquanto que no caso do reator de membrana foram necessárias apenas 340 unidades de CGTase (KIM et al., 1993).

Há também métodos que usam 2-propanol como precipitante e avaliação de UVvis para purificação de $\beta$-CDs (SOPHIANOPOULUS e WARNER, 1992). Segundo CHATJIGAKIS et al. (1992), a adição de uréia, metais, etanol, propanol, e acetonitrila são alguns solventes usados para solubilizar CDs. Estes autores ainda afirmam que o tempo de fluorescência emitida pelo complexo pirena- $\chi-C D$ depende da natureza do solvente empregado na extração das CDs. Tais afirmações sugerem que o solvente em questão pode alterar a estrutura das moléculas de CDs.

\subsection{Quantificação das CDs}

A habilidade das CDs de formar complexos com metilorange, iodo e fenolftaleína, possibilita sua quantificação através de métodos espectrofotométricos, quando presentes em pequenas concentrações. NAKAMURA et al. (1992) quantificaram $\beta$-CDs através do método de coloração por fenolftaleína (VIKMON, 1981). Esses métodos apresentam como principal desvantagem a interferência de dextrinas lineares e compostos coloridos e turbidez dos reagentes (LAAKSO et al., 1992).

Um dos primeiros trabalhos em que se quantificou a produção de CDs foi feito por KITAHATA e OKADA (1974), que usaram amido marcado com ${ }^{14} \mathrm{C}$. Outros autores usaram ${ }^{14} \mathrm{C}$ para quantificar a formação de $\mathrm{CDs}$ durante vários períodos de reação (NAKAMURA e HORIKOSHI, 1976). 
LAAKSO et al. (1992) desenvolveram um método para quantificação de CDs baseado na sua habilidade de formar complexos com o ácido oléico e na incapacidade da lipoxigenase de soja de oxidar tais complexos. Neste método, CDs nas concentrações de 0,02-0,04 mM são quantificadas, apresentando como principal vantagem a rapidez.

OHNISHI et al. (1994) usaram ácido 6-sulfônico 2-p-toluidinalftaleno (TNS) como agente fluorescente na determinação de CDs. Segundo estes autores, o complexo de inclusão formado entre CDs e TNS é um composto fluorescente que pode ser excitado a $366 \mathrm{~nm}$ e quantificado através de leitura feita a $468 \mathrm{~nm}$.

NARDI et al. (1990) quantificaram CDs através de detecção fotométrica por UV. Para isso, se basearam na complexação de CDs com ácido benzóico, que serve como componente de absorção de UV.

METZGER et al. (1991) analisaram a estrutura, a pureza e o peso molecular de CDs os complexos $\beta$-CDs-2,3,6-tri-O-metil; $\alpha$-CDs-2,3,6-tri-O-metil; $\chi$-CDs-2,3,6-triO-metil; $\beta$-CDs-2,3,6-tri-O-pentil; $\alpha$-CDs-2,3,6-tri-O-pentil; $\chi$-CDs-2,3,6-tri-O-pentil; $\beta$-CDs-2,6-di-O-metil-3-O-trifluoracetil através de espectrometria de massa. Há também trabalhos que avaliaram a formação do complexo derivado de $\beta$-CD com $1,4,10,13$ tetraoxa-7,16-diazaciclooctadecano através de espectrometria de massa com bombardeamento atômico (PIKRAMENOU et al., 1993).

RAJA e RAMAKRISHNA (1994) separaram as $\beta$-CDs presentes em hidrolisado com bromobenzeno, visto que o complexo formado por $\beta$-CDs-bromobenzeno precipita facilmente à temperatura ambiente. Em seguida o precipitado foi filtrado e seco à vácuo e a quantificação de $\beta$-CDs foi feita por gravimetria. RAJA et al. (1990), usando precipitação de $\beta$-CDs por bromobenzeno e clorofórmio, quantificaram CDs através de espectrofotometria e por termogravimetria.

Um dos métodos mais usados para quantificação de CDs é a Cromatografia Líquida de Alta Eficiência (HPLC - High Performance Liquid Cromatography). Segundo ZSADON et al. (1979), uso de coluna de açúcares é um dos métodos mais adequados para analisar CDs, e com calibração apropriada também pode ser método quantitativo através do cálculo das áreas dos picos. Apenas HPLC pode discriminar diferenças entre 
CDs metiladas (heptakis-(2,6-O-di-metil- $\beta$-CD)) e seus isômeros heptakis-(2,3-O-dimetil) e heptakis-(3,6-di-O-metil)- $\beta$-CD (SZEJTLI, 1984). A separação de $\beta$-CDs e de $\beta$-CD-hidroxipropil usando água:acetonitrila como fase móvel em HPLC acoplado à detector polarimétrico é um método sensível e seletivo (LIU et al., 1993). Picos de $\alpha$ CDs geralmente são mais definidos que os de $\beta$ e $\chi$-CDs (CHATJIGAKIS et al., 1993). Muitas colunas são empregadas para análise de CDs, e a fase móvel varia consideravelmente quando à proporção e natureza dos componentes. A tabela 10 lista algumas metodologias usadas para quantificar CDs.

KOIZUMI et al. (1988) compararam a performance de oito colunas através de fatores de assimetria dos picos e do número de platôs teóricos e constataram que CDs ramificadas foram satisfatoriamente separadas de não ramificadas usando eluente com 3-7\% de metanol. Esses autores também obtiveram melhores resultados com colunas empacotadas com resinas C18-sílica e com metanol/água como fase móvel que com colunas empacotadas com $\mathrm{NH}_{2}$-sílica com acetonitrila/água como fase móvel.

YAMAMOTO e HORIKOSHI (1981), observaram tempo de retenção de 10,5 minutos para $\alpha$-CDs a $40^{\circ} \mathrm{C}$ e fluxo de $1,0 \mathrm{ml} / \mathrm{min}$, tendo acetonitrila/água como fase móvel. Segundo ZSADON et al. (1979), o tempo de retenção varia em função da composição da fase móvel, sendo que a seletividade pode ser alterada pela mudança da proporção acetonitrila:água. Na maioria dos casos, o aumento de temperatura da coluna elimina os picos anoméricos, os quais causam distorções das leituras dos picos principais por coincidirem com seu tempo de retenção. Concentrações de acetonitrila:água superiores a 60:40 ocasionam problemas com a solubilidade da amostra (WHITE et al., 1992). Com o objetivo de aumentar a resolução de $\chi$-CDs e G5, KOIZUMI et al. (1987) aumentaram a proporção de acetonitrila usada como eluente. Estes autores conseguiram eliminar picos anoméricos, evidentes com a coluna a $50^{\circ} \mathrm{C}$, elevando a temperatura da coluna a $75^{\circ} \mathrm{C}$. 
Tabela 10.Diferentes metodologias para determinação de CDs, usando HPLC.

\begin{tabular}{|c|c|c|c|c|}
\hline Coluna & Temperat & Fase móvel & Fluxo & Referência \\
\hline C18-sílica & - & metanol/água & - & $\begin{array}{l}\text { KOIZUMI et al. } \\
\text { (1988) }\end{array}$ \\
\hline $\mathrm{NH}_{2}$-sílica & - & acetonitrila/água & - & $\begin{array}{l}\text { KOIZUMI et al. } \\
\text { (1988) }\end{array}$ \\
\hline HPX-42 A & $76^{\circ} \mathrm{C}$ & água destilada & $\begin{array}{c}0,5 \\
\mathrm{ml} / \mathrm{min}\end{array}$ & $\begin{array}{c}\text { OKADA et al. } \\
\text { (1994 a) }\end{array}$ \\
\hline $\mathrm{NH}_{2}$-sílica & - & $\begin{array}{c}\text { acetonitrila/água } \\
\qquad(65: 35)\end{array}$ & $\begin{array}{c}1,0 \\
\mathrm{ml} / \mathrm{min}\end{array}$ & $\begin{array}{l}\text { LEE e KIM et al. } \\
\qquad(1993)\end{array}$ \\
\hline Shodex NHpakj-411 & $40^{\circ} \mathrm{C}$ & acetonitrila/água & $\begin{array}{c}1,0 \\
\mathrm{ml} / \mathrm{min}\end{array}$ & $\begin{array}{c}\text { YAMAMOTO e } \\
\text { HORIKOSHI (1981) }\end{array}$ \\
\hline NH2-Bondapak & $40^{\circ} \mathrm{C}$ & $\begin{array}{c}\text { acetonitrila/água } \\
(65: 35)\end{array}$ & $\begin{array}{c}1,0 \\
\mathrm{ml} / \mathrm{min}\end{array}$ & YU et al. (1988) \\
\hline ZORBAX-NH2 & - & $\begin{array}{c}\text { acetonitrila/água } \\
\qquad(65: 35)\end{array}$ & $\begin{array}{c}1,0 \\
\mathrm{ml} / \mathrm{min}\end{array}$ & $\begin{array}{c}\text { SABIONI e PARK } \\
(1992)\end{array}$ \\
\hline HPX-42A & $70^{\circ} \mathrm{C}$ & água destilada & $\begin{array}{c}0,5 \\
\mathrm{ml} / \mathrm{min}\end{array}$ & $\begin{array}{l}\text { KANEKO et al. } \\
\qquad(1990 \mathrm{a})\end{array}$ \\
\hline Asahipak C8P-50 & $45^{\circ} \mathrm{C}$ & $\begin{array}{c}\text { metanol/água } \\
(10: 90)\end{array}$ & $\begin{array}{c}0,8 \\
\mathrm{ml} / \mathrm{min}\end{array}$ & $\begin{array}{l}\text { OHNISHI et al. } \\
\qquad(1994 \text { a) }\end{array}$ \\
\hline $\begin{array}{c}\text { Tosoh TSK-Gel } \\
\text { Amide } 80\end{array}$ & $40^{\circ} \mathrm{C}$ & $\begin{array}{c}\text { acetonitrila/água } \\
(65: 35)\end{array}$ & $\begin{array}{c}1,0 \\
\mathrm{ml} / \mathrm{min}\end{array}$ & $\begin{array}{c}\text { SAKAI et al. } \\
\text { (1991);HAYASHIDA } \\
\text { e KAWAKAMI } \\
(1992)\end{array}$ \\
\hline LiCrospher $100 \mathrm{NH} 2$ & $20^{\circ} \mathrm{C}$ & $\begin{array}{c}\text { acetonitrila/água } \\
(65: 35)\end{array}$ & $\begin{array}{c}0,8 \\
\mathrm{ml} / \mathrm{min}\end{array}$ & $\begin{array}{l}\text { NAKAMURA et al. } \\
\text { (1993) }\end{array}$ \\
\hline LiCrospher RP & $23^{\circ} \mathrm{C}$ & $\begin{array}{c}\text { água/etanol } \\
\text { água/acetonitrila }\end{array}$ & $\begin{array}{c}1,0 \\
\mathrm{mlml} / \mathrm{min}\end{array}$ & $\begin{array}{c}\text { CHATJIGAKIS et al } \\
\text { (1993) }\end{array}$ \\
\hline
\end{tabular}


CHATJIGAKIS et al. (1993) avaliaram a hidrofobicidade das CDs usando como fase móvel misturas de água/etanol e água/acentonitrila e concluíram que a mistura água metanol é mais adequada para a separação e determinação cromatográfica de CDs. A solubilidade de $\beta-C D$ em misturas de água/acetonitrila aumenta com o aumento da porcentagem de acetonitrila. $\alpha-C D$ é a mais hidrofïlica das três $C D s$, enquanto a $\beta-C D s$ é a mais hidrofóbica (CHATJIGAKIS et al., 1993).

TAKEGUCHI e MIWA (1994) usaram fenolftaleína para detectar $\beta$ e $\chi$-CDs em cromatografia líquida. Segundo estes autores, a detecção é feita através da depressão causada pelo "background" de absorbância decorrente da formação do complexo fenolftaleína/CDs. Este método se baseia no princípio da queda da intensidade de coloração da fenolftaleína causada pela complexação com CDs e não se aplica para deteç̧ão de $\alpha$-CD devido ao fato de sua cavidade ser pequena para a encapsulação da fenolftaleína. Já $\beta$-CDs apresenta pico 4,8 vezes maior que $\chi$-CD. Para tal método, é importante observar que o aumento do tempo de retenção, obtido com o decréscimo da concentração de acetonitrila na fase móvel, resulta em perda de sensibilidade (TAKEGUCHI e MIWA, 1994). FUKUDA et al. (1993) desenvolveram um método para quantificar $\beta-C D$ e glicosil- $\beta-C D$ presente em urina e fezes através de HPLC com detecção por amperometria (PAD).

Segundo WHITE et al. (1992), através de HPLC é possível determinar as impurezas presentes na $\chi-C D$ de diferentes fabricantes, revelando grande precisão do método. Devido à alta precisão do HPLC, muitas vezes há necessidade de preparo prévio das amostras. YU et al. (1988) filtraram as amostras antes da injeção com filtros descartáveis de $45 \mu \mathrm{m}$, da Millipore. O emprego de enzimas na amostra visando auxiliar na leitura cromatográfica também é um recurso bastante usado. Para isso, as amostras sofrem reação enzimática antes de serem analisadas. TREDER et al. (1989), reagiram amostras com mistura de $\alpha$-amilase e glucoamilase a $55^{\circ} \mathrm{C}$ por duas horas antes da análise em HPLC. Muitos trabalhos afirmam que glucoamilase não degrada CDs e é 
portanto indicada para facilitar sua quantificação em HPLC (OKADA et al., 1994 b ; KANEKO et al., 1990 b; NAKAMURA et al., 1993; SABIONI ,1993). OKADA et al. (1994 a) usaram glucoamilase para converter maltoligossacarídeos em glucose a fim de facilitar a análise em HPLC. NAKAMURA et al. (1993) verificaram a proporção de $\alpha: \beta: \chi-C D s$ após hidrólise das dextrinas lineares com glucoamilase (EC 3.2.1.3.), proveniente de Rhizopus niveus. Segundo SABIONI e PARK (1992), foram usados $2 \mathrm{ml}$ de amiloglucosidase para de hidrolisar o amido não convertido em CDs e assim facilitar a leitura do cromatograma. 


\section{MATERIAL E MÉTODOS}

\subsection{Matéria prima}

Foram empregados fécula e farelo de mandioca como matéria prima para produção de $\mathrm{CDs}$, ambos extraídos de raízes de mandioca com dois anos de idade, da cultivar Branca de Santa Catarina (Manihot esculenta Crantz). Fécula e farelo foram cedidos pela Fecularia Botega, localizada na região de Cândido Mota - S.P.. A fécula correspondeu ao processo de extração industrial. O farelo, após sofrer secagem em estufa durante 10 horas a $60^{\circ} \mathrm{C}$, foi moído em moinho tipo Willey, com peneira de malha del,23 mm de diâmetro e submetido à caracterização.

Os substratos foram caracterizados quanto aos teores de umidade, proteína, amido, matéria graxa, cinzas, fibras (A.O.A.C., 1980), pH e acidez (INSTITUTO ADOLFO LUTZ, 1985).

\subsection{Enzimas, reagentes e equipamentos}

\subsubsection{Enzimas}

As enzimas usadas foram:

- celulase (E.C.3.2.1.1.) Celluclast 1.5 1 Batch (CCN 3038), da Novo Nordisk Ferment Ltda.

- $\alpha$-amilase (E.C. 3.2.1.4.) Tenase de Bacillus subtilis, diluída $1 / 100$ em tampão fosfato $0,1 \mathrm{~N} \mathrm{pH} \mathrm{6,0,} \mathrm{com} \mathrm{atividade} \mathrm{de} 680.000 \mathrm{MWU} / \mathrm{g}$, onde $1 \mathrm{MWU}$ hidrolisa $1 \mathrm{mg}$ de amido solúvel / 30 minutos

- ciclodextrina glucosiltransferase (CGTase E. C. 2.4.1.19) de Bacillus macerans da Amano International Enzyme Co. Inc. (Nagoya, Japão), com mais de 600 unidades/ml, segundo método de Tilden e Hudson (1942). De acordo com RENDLEMAN (1992), a unidade da CGTase é definida como sendo a quantidade de enzima necessária para produzir $1 \mu \mathrm{ml}$ de $\mathrm{CDs} /$ minuto a partir de amido solúvel de batata em $\mathrm{pH} 6,0$ a $60^{\circ} \mathrm{C}$. Assim cada ml da CGTase possui cerca de 5,6 unidades. 
- $\beta$-amilase (E.C. 3.2.1.2.) da Sigma (A 7130), proveniente de cevada, com 53 unidades/ mg de sólido, sendo 1 unidade o equivalente à liberação de $1 \mathrm{mg}$ de maltose $/ 3 \mathrm{~min}$., em $\mathrm{pH} 4,8$ a $20^{\circ} \mathrm{C}$.

\subsubsection{Reagentes}

Para a identificação das frações e estabelecimento das curvas padrões, usou-se D-glucose monohidratada (C 04319) da Cinética Química Ltda., maltose (400) da Vetec Química Fina Ltda, amido solúvel Reagen Químibrás Ind. S. A. (10037). As CDs usadas foram $\alpha$-CD (C-4642) (97\% pureza) da Sigma, $\beta$-CD (C-4767) da Sigma e $\chi$-CD (2128) (98\% pureza) da Merck. Amilose (A0512) e amilopectina (A8515) da Sigma proveniente de batata foram usadas.

\subsubsection{Banhos termostáticos}

Os ensaios prévios sobre liquefação do farelo foram realizados em enrlenmeyer de $250 \mathrm{ml}$, imerso em banho-maria Dubnoff MA 093.

Conduziu-se as reações de produção de CDs em copo hermético de aço inoxidável provido com haste acoplada em agitador mecânico de velocidade máxima de 18.000 rpm da Tecnal TE-039, e imerso em banho-maria Dubnoff MA 093, com controle de temperatura.

\subsubsection{Prensagem e centrífugação das amostras}

Para prensagem do farelo foi construída prensa adaptada com uma pequena chapa metálica soldada em rosca sem fim e acoplada à uma peneira que foi inserida em recipiente coletor (Figuras 15 e 16).

A centrífugação prévia das amostras foi feita após estas haverem sido transferidas para tubos de Eppendorf, a 12.000 rpm por 15 minutos em centrifuga Centrimicro Mod. 123 da Fanem. 


\subsubsection{Análises}

As análises para mensuração de extremidades redutoras (ER) e de amido liquefeito não hidrolisado foram feitas em espectrofotômetro Femto Mod.431.

As análises de perfil dos hidrolisados e a avaliação da produção de CDs foram feitas em HPLC usando coluna para carboidratos Aminex HPX-42 A (300 x 7.8 mm) Cat. 125-0097, tendo água deionizada e filtrada como fase móvel. Empregou-se detector de interface dielétrica Refracto Monitor IV LDC. As amostras foram passadas através de filtros descartáveis de $0,25 \mu \mathrm{m}$ da Millipore antes de serem injetadas. O software usado para registro dos cromatogramas foi CHROMA V. 3.18, da Biosystemes.

\subsection{Métodos}

\subsubsection{Padrões para HPLC}

A identificação dos picos referentes à glucose e maltose e o estabelecimento das curvas padrões de $\alpha$ e $\beta$-CDs foram feitos através da análise em HPLC, com água destilada e filtrada como fase móvel e coluna à temperatura de $70^{\circ} \mathrm{C}$, com fluxo de 0,5 $\mathrm{ml} / \mathrm{min}$ (KANEKO et al., 1990 a). A curva padrão de CDs foi feita com as seguintes concentrações: 10.000, 5.000, 2.500, 1.250 e $625 \mu \mathrm{g}$ de $\alpha, \beta$ e $\chi-\mathrm{CD} / \mathrm{ml}$ (Apêndice 1, 2 e 3).

Uma suspensão com fécula a 5\% foi completada com $100 \mathrm{ml}$ de água destilada e hidrolisada com $\alpha$-amilase durante 15 minutos a $60^{\circ} \mathrm{C}$, com o objetivo de obter dextrinas lineares e seus polimerizados intermediários. Esta solução foi usada como padrão para verificar se os picos relativos às dextrinas lineares não coincidiam com os picos relativos às CDs.

Cromatogramas de amostras resultantes da ação da CGTase apresentaram picos não identificados. Visando identificar se estes picos (tempo de retenção entre 20.8021.11 minutos), correspondiam à CDs ramificadas, amilose e amilopectina foram usados como substratos de reação com CGTase. 


\subsubsection{Pré tratamentos do farelo}

Devido à alta viscosidade inerente das suspensões de farelo, houve necessidade de realizar um pré tratamento, visando propiciar mistura homogênea da CGTase e, conseqüentemente, aumento da produção de CDs. Primeiramente foi selecionada a melhor enzima para o pré tratamento. Para isso, foram feitas três suspensões de farelo em água destilada com concentração de $5 \%$ (5 g farelo/100 ml). Estas suspensões foram submetidas então, separadamente, à ação as seguintes enzimas:

- $1 \mathrm{ml}$ de celulase, incubada a $40^{\circ} \mathrm{C}$ durante 20 minutos

- $1 \mathrm{ml}$ de $\alpha$-amilase, incubada a $60^{\circ} \mathrm{C}$ durante 1 hora

$-1 \mathrm{ml}$ de ciclodextrina glucosiltransferase, incubada a $80^{\circ} \mathrm{C}$ durante 30 minutos

As três suspensões foram imersas em banho maria com agitação. A desativação das enzimas foi feita colocando amostras da reação em banho-maria a $90-100^{\circ} \mathrm{C}$ durante 15 minutos. Em seguida as amostras foram transferidas para tubos de Eppendorf e centrifugadas.

As amostras foram então diluídas em água destilada e deionizada a 1:2 e analisadas por HPLC.

De acordo com os resultados obtidos após esta análise, selecionou-se CGTase como enzima para ser usada no pré tratamento do farelo para produção de CDs.

\subsubsection{Produção de CDs}

Foram avaliados fécula ( T1 ) e farelo ( T2 ) de mandioca como substratos para a produção de $\mathrm{CDs}$, em dois tratamentos com três repetições por tratamento. As reações foram feitas usando suspensões de $5 \%$ de substrato $(10 \mathrm{~g} / 200 \mathrm{ml})$. Tanto a fécula como o farelo foram previamente tratados com $1 \mathrm{ml}$ de CGTase a $80^{\circ} \mathrm{C}$ durante 15 minutos, no caso da fécula e 40 minutos quando o substrato em questão foi o farelo. Em seguida esperou-se que a temperatura da reação atingisse $50^{\circ} \mathrm{C}$, temperatura na qual a perda de atividade da enzima é menor (RENDLEMAN, 1992), para que fosse adicionado mais 1 $\mathrm{ml}$ de CGTase. A reação foi então completada em copo hermético de aço inoxidável provido com haste acoplada a agitador mecânico e imerso em banho-maria, durante 24 
horas. Coletou-se amostras após a liquefação e após 2, 4, 6, 8, 10, 12, 22 e 24 horas de reação, em quantidade suficiente para as análises.

\subsubsection{Preparo das amostras}

Devido ao fato da suspensão do farelo ter apresentado viscosidade crescente com o tempo de reação, foi realizada prensagem visando recuperar material líquido. Após a prensagem, o líquido foi tomado como amostra para análise. Foi feito tratamento térmico das amostras entre $90-100^{\circ} \mathrm{C}$ durante 15 minutos, visando a inativação enzimática. As suspensões foram então centrifugadas e o precipitado descartado.

Tanto as amostras originarias do substrato fécula como do farelo foram submetidas à centrífugação. Estas amostras foram analisadas quanto ao teor de amido residual, quanto à quantidade de extremidades redutoras e estabelecido o perfil do hidrolisado.

As amostras destinadas à determinação de CDs, após centrifugadas foram tratadas com $\beta$-amilase. Este procedimento foi devido ao fato de $\alpha$-CD usada como padrão apresentar pico coincidente com dextrinas lineares de D.P 6-7. O tratamento consistiu na adição de $\beta$-amilase às amostras antes da injeção em HPLC, visando hidrolisar as dextrinas lineares. A reação foi feita em $1 \mathrm{ml}$ de amostra usando $0,5 \mathrm{ml}$ de enzima a $0,002 \mathrm{~g} / \mathrm{ml} \mathrm{a} 25^{\circ} \mathrm{C}$ na proporção, durante 1 hora e a inativação enzimática foi feita a $90-100^{\circ} \mathrm{C} / 15$ minutos, seguida de centrífugação a $12.000 \mathrm{rpm}$ por 15 minutos (ALVAREZ et al., 1994). As amostras foram então novamente centrifugadas, diluídas e filtradas antes da injeção.

\subsubsection{Análises}

\subsubsection{Amido residual}

As amostras foram avaliadas quanto ao amido gomificado não hidrolisado através do método de coloração de iodo e a leitura em espectrofotômetro a $620 \mathrm{~nm}$ (BANKS et al., 1971). O estabelecimento da curva padrão de amido foi feito usando amido solúvel para as concentrações de 5, 4, 3, 2 e $1 \mathrm{mg} / \mathrm{ml}$ (Apêndice 4). 


\subsubsection{Extremidades redutoras}

A dosagem de extremidades redutoras foi feita pelo método do ácido dinitrossalicílico (ADNS) e a leitura a $535 \mathrm{~nm}$. As extremidades redutoras foram caracterizadas pelo poder redutor das cadeias de amido hidrolisado, representando dextrinas de diferentes pesos moleculares. Para o estabelecimento da curva padrão da ER (extremidades redutoras), usou-se D-glucose monohidratada a $0,5,1,0,1,5$ e $2,0 \mathrm{mg} / \mathrm{ml}$ (Apêndice 5).

\subsubsection{Ciclodextrinas}

$\mathrm{O}$ perfil da reação e a produção de $\alpha$ e $\beta$-CDs foram avaliados através de Cromatografia Líquida de Alta Eficiência (HPLC), segundo KANEKO et al. (1990 a). Devido ao fato da CGTase usada ser produtora de $\alpha$ e $\beta$-CD, não houve necessidade de se fazer a análise da produção de $\chi-\mathrm{CD}$, uma vez que ensaios prévios mostraram apenas traços de $\chi$-CD nas amostras.

\subsubsection{Análise estatística}

Foi feita análise estatística em blocos com parcelas subdivididas ("split splot"). Também analisou-se a correlação entre a produção de $\alpha-C D, \beta-C D$, extremidades redutoras e amido gomificado não hidrolisado (BANZATTO e KRONKA, 1989). O software usado foi SAS.

As figuras a seguir apresentam as seqüências dos ensaios de produção de CDs a partir de fécula (Fig. 13.) e farelo (Fig. 14). 
suspensão $5 \%$ de fécula $(10 \mathrm{~g} / 200 \mathrm{ml})+1 \mathrm{ml}$ de CGTase
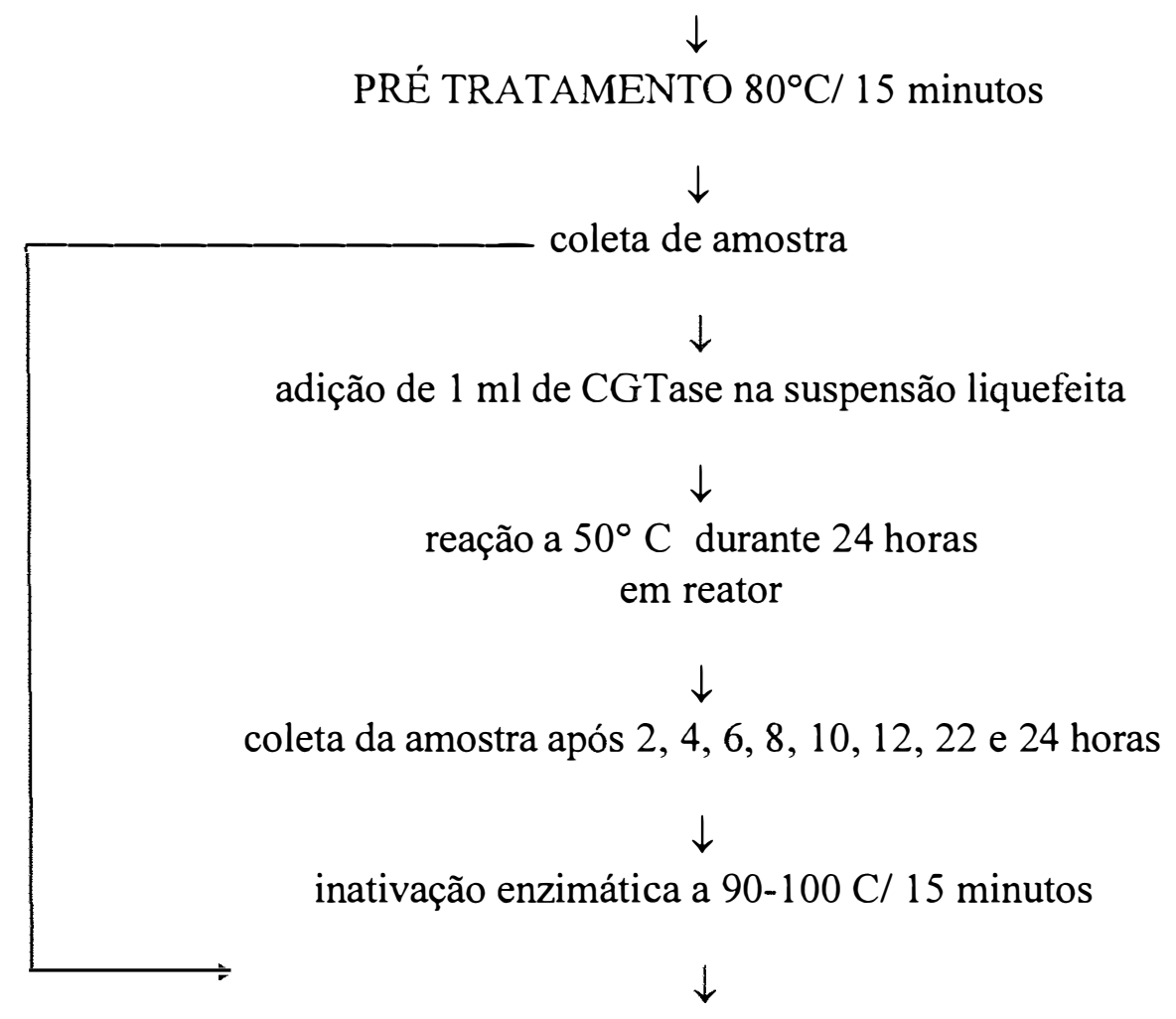

centrífugação $12.000 \mathrm{rpm} / 15$ minutos

Análise do amido residual

Reação com $\beta$-amilase

Análise de ER $25^{\circ} \mathrm{C} / 1$ hora

Inativação enzimática

$90-100^{\circ} \mathrm{C} / 15$ minutos

$\downarrow$

Diluição das amostras

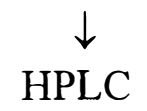

Figura 13. Fluxograma referente à produção de CDs usando fécula como substrato. 
suspensão $5 \%$ de farelo $(10 \mathrm{~g} / 200 \mathrm{ml})+1 \mathrm{ml}$ de CGTase

PRÉ TRATAMENTO $80^{\circ} \mathrm{C} / 40$ minutos

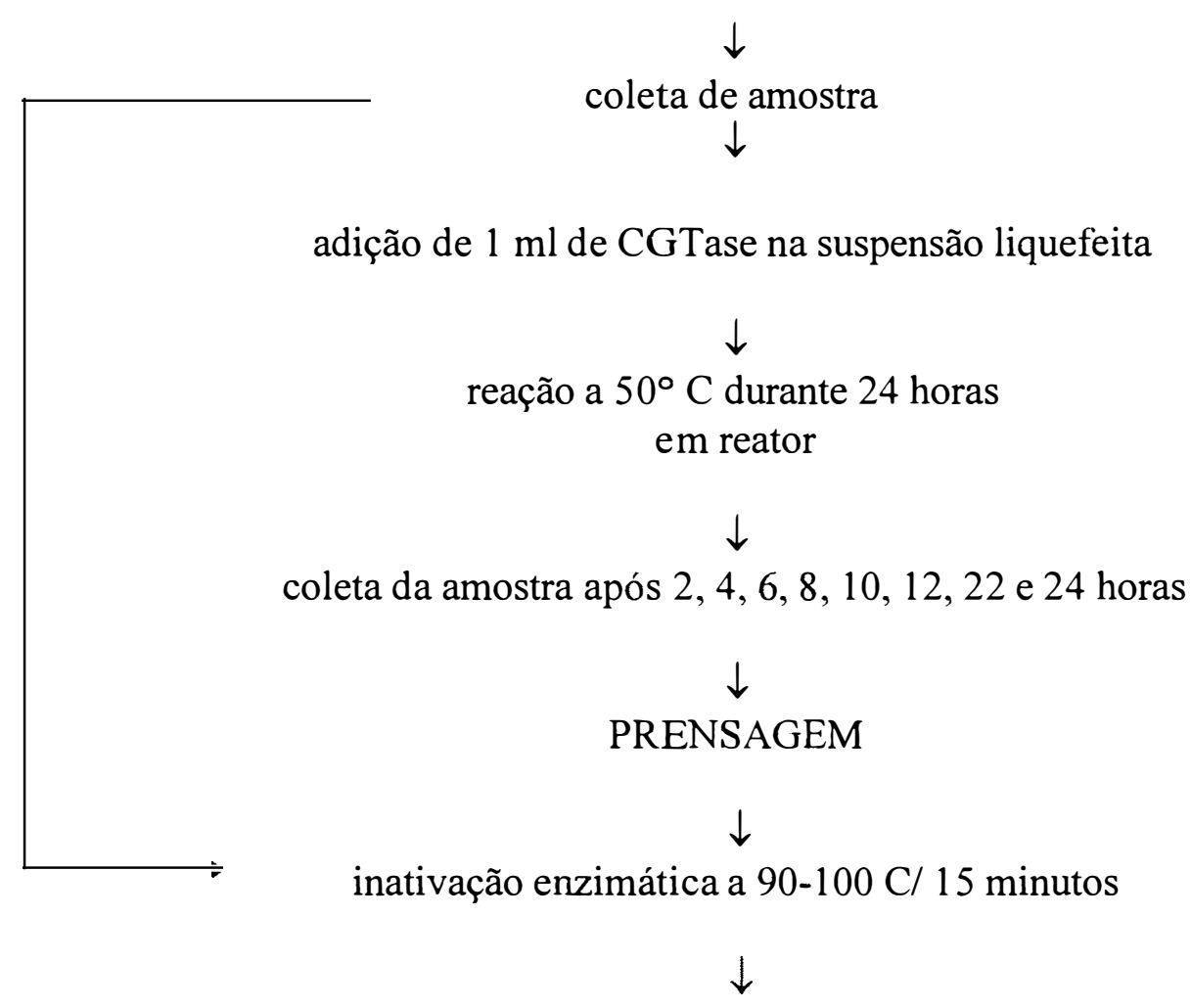

centrífugação $12.000 \mathrm{rpm} / 15$ minutos

Análise do amido residual

Reação com $\beta$-amilase

Análise de ER $25^{\circ} \mathrm{C} / 1$ hora

$\downarrow$
Inativação enzimática
$90-100^{\circ} \mathrm{C} / 15$ minutos

$\downarrow$

Diluição das amostras

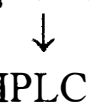

Figura 14. Fluxograma referente à produção de $\mathrm{CDs}$ usando farelo como substrato. 

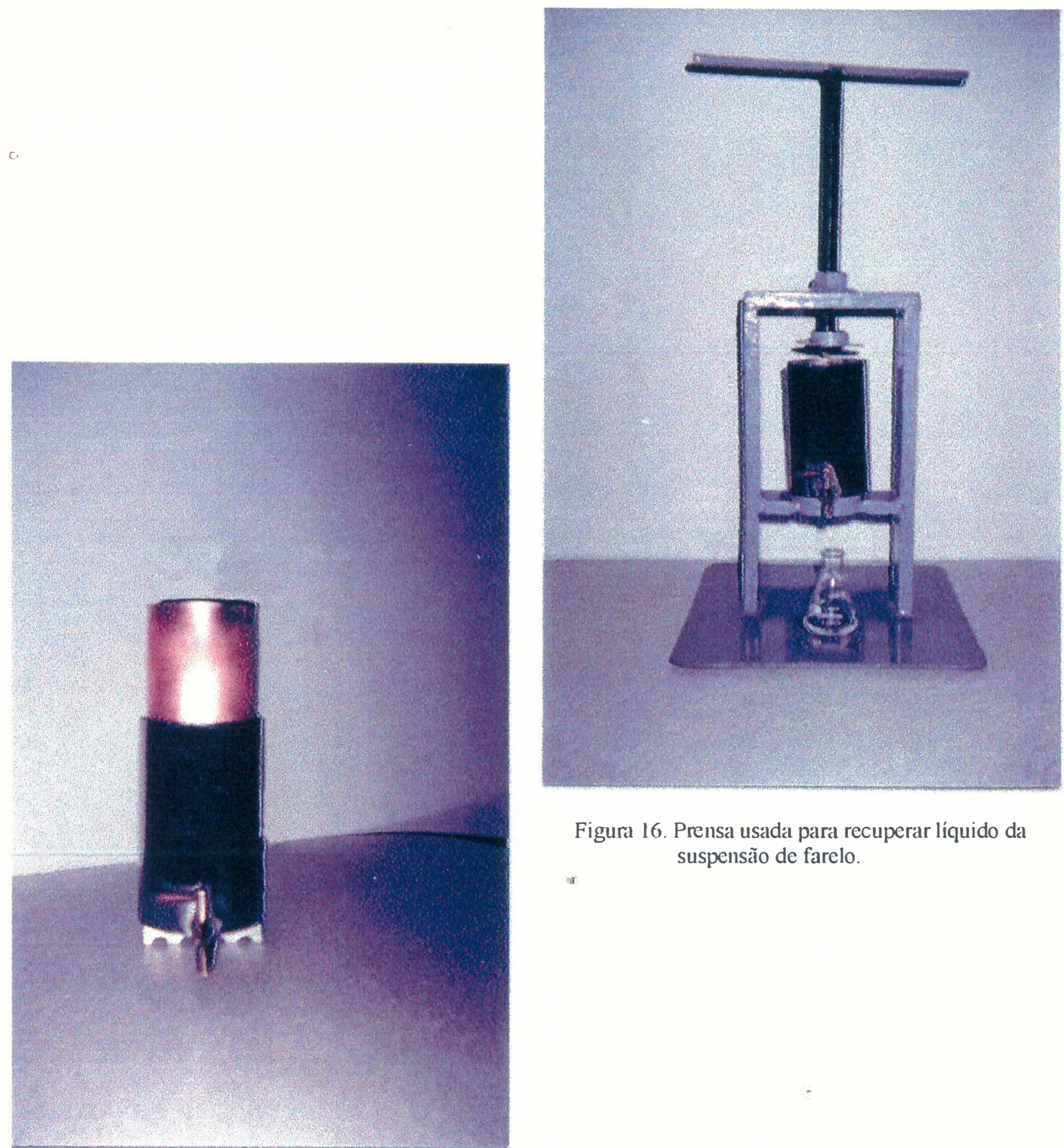

Figura 16. Prensa usada para recuperar líquido da suspensão de farelo.

Figura 15. Pcneira de cobre inserida no recipiente coletor de aço inoxidável. 


\section{RESULTADOS E DISCUSSÃO}

\subsection{Caracterização dos substratos}

Os resultados da caracterização dos substratos encontram-se listados na Tabela 11.

Tabela 11. Caracterização dos substratos usados para produção de CDs.

\begin{tabular}{ccc}
\hline Análise & Fécula & Farelo \\
\hline Umidade (\%) & 7,90 & 5,20 \\
\hline \% de matéria seca & & \\
\hline Proteína & 0,27 & 1,38 \\
Amido & 98,85 & 74,21 \\
Matéria graxa & 0,06 & 0,32 \\
Cinzas & 0,30 & 1,58 \\
Fibras & 0,45 & 16,21 \\
\hline Amilose (\% de amido) & 18,80 & $-*$ \\
Acidez (ml/100g de amostra) & 0,35 & 3,00 \\
pH & 7,48 & 5,37 \\
\hline
\end{tabular}

*-: não determinado

A fécula usada como matéria prima apresenta valores de umidade abaixo da média encontrada pelas fecularias do sudeste brasileiro, que é de $12,74 \% \mathrm{O}$ pH médio das féculas brasileiras está entre 5,0 a 5,9 (VILPOUX e CEREDA, 1995), observando assim que a fécula usada apresenta menor acidez que a maioria das obtidas pelas fecularias. $\mathrm{O}$ teor de cinzas da fécula usada foi de $0,30 \%$, semelhante ao encontrado nas demais féculas com 0,24\% (VILPOUX e CEREDA, 1995). O teor de amilose da fécula foi de $18,80 \%$ do total de amido, próximo aos valores médios da fécula extraída de raízes do cultivar Branca de Santa Catarina, que é de 18,33\% do total de amido (WOSIACKI et al., 1990). Para o mesmo cultivar, esses autores encontraram teores de amido próximos à $97,27 \%$ e teores de proteína entre 0,9 e $0,12 \%$. Observa-se portanto que os valores da Tabela 11 para amido, proteína, fibras e amilose encontram-se na mesma faixa que os valores observados por WOSIACKI et al. (1990). 
O resultado das análises de caracterização mostra que o farelo, apesar da grande quantidade de fibras, possui teor de amido de $74,21 \%$. Esse valor está abaixo da fécula (maior que 90\%) e da farinha de mandioca (cerca de $80 \%$ ). A principal diferença observada entre as análises de fécula e farelo é que este apresenta alto teor de fibra, o que resulta em aumento considerável da viscosidade da suspensão de farelo, quando comparado à suspensão de fécula.

A média do teor de amido no farelo das fecularias do sudeste brasileiro está em torno de 73,78\% (GRIFFON et al. 1995), sendo portanto o farelo utilizado, uma amostra com representatividade industrial. Segundo CEREDA (1994), os teores de amido no farelo proveniente das fecularias dos estados do Paraná e São Paulo são menores que os ocorrentes nos farelos obtidos das fecularias da região de Minas Gerais, como característica de tecnologias que empregam equipamentos regionais específicos. $\mathrm{O}$ teor de amido encontrado no farelo (Tabela 11) é equivalente à média obtida nas fecularias de Minas Gerais (CEREDA, 1994). Já o teor de fibras encontra-se ligeiramente acima das médias observadas nas fecularias da São Paulo, Paraná e Minas Gerais; as quais oscilam entre 7,81 e 14, 88\% (CEREDA, 1994). O teor de cinzas no farelo usado $(1,58 \%)$ é maior que a média encontrada no farelo provenientes das fecularias paranaenses $(0,66 \%)$ e paulistas $(0,83 \%)$, porém é menor que a média do farelo das fecularias do estado de Minas Gerais (3,77\%). O mesmo acontece em relação aos teores de proteína, 1,38\% no farelo analisado, em comparação a $0,24 \%$; média para o farelo das fecularias paulistas, sendo que as paranaenses apresentam médias de $0,32 \%$ e as mineiras $1,86 \%$.

\subsection{Identificação dos padrões para HPLC}

Além das $\alpha, \beta$ e $\chi$-CDs, adotou-se como padrão os açúcares derivados da hidrólise do amido, como maltose e glicose. Os tempos de retenção de $\alpha, \beta$ e $\chi$-CDs foram respectivamente 11,20, 25,95 e 17,48 minutos (Fig. 17). Conforme se observa nos cromatogramas das Figuras 17 e 18, o tempo de retenção (T.R.), em minutos, de glicose e maltose não foram coincidentes com os de $\alpha$ e $\beta$-CDs, empregando-se a metodologia de KANEKO et al. (1985 a). Gama-CD porém apresentou tempo de retenção 
intermediário entre maltose e glicose (Figs. 17 e 18), o que dificultaria a identificação destes picos nestas condições de análise.

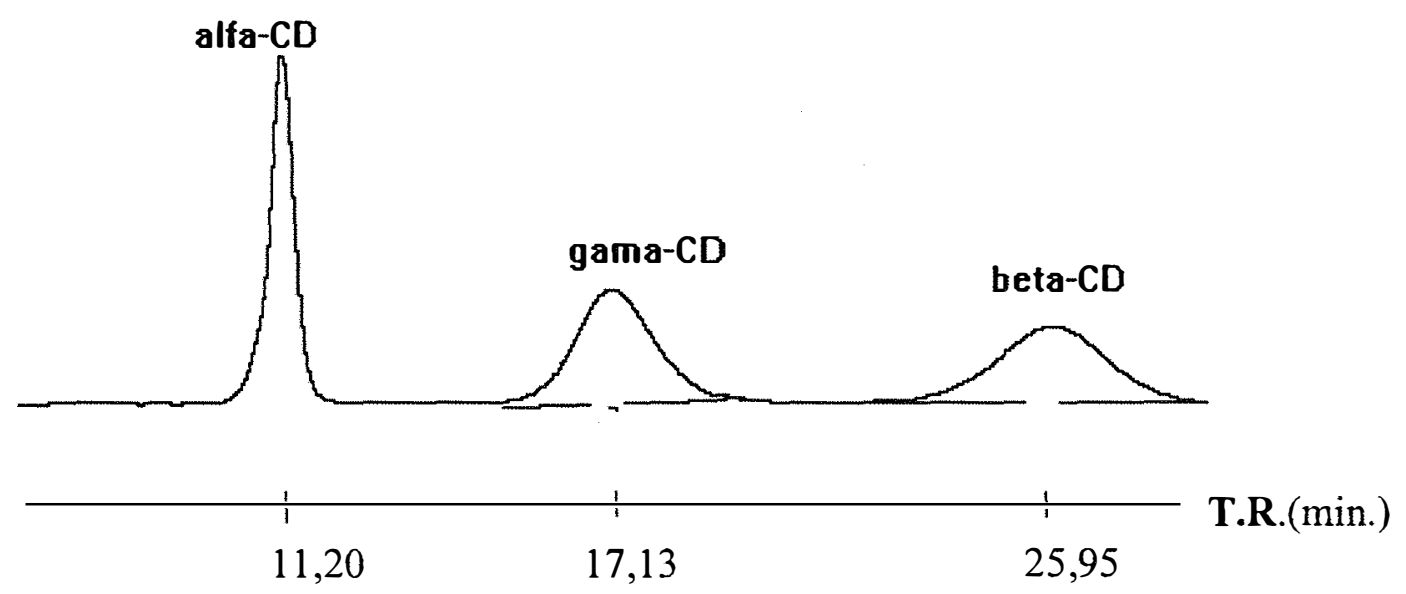

Figura 17. Cromatograma padrão de $\alpha, \beta$ e $\chi$-CDs.

O pico de glicose apresentou tempo de retenção de 18,73 minutos, enquanto o pico de maltose teve tempo de retenção próximo de 16,51 minutos.

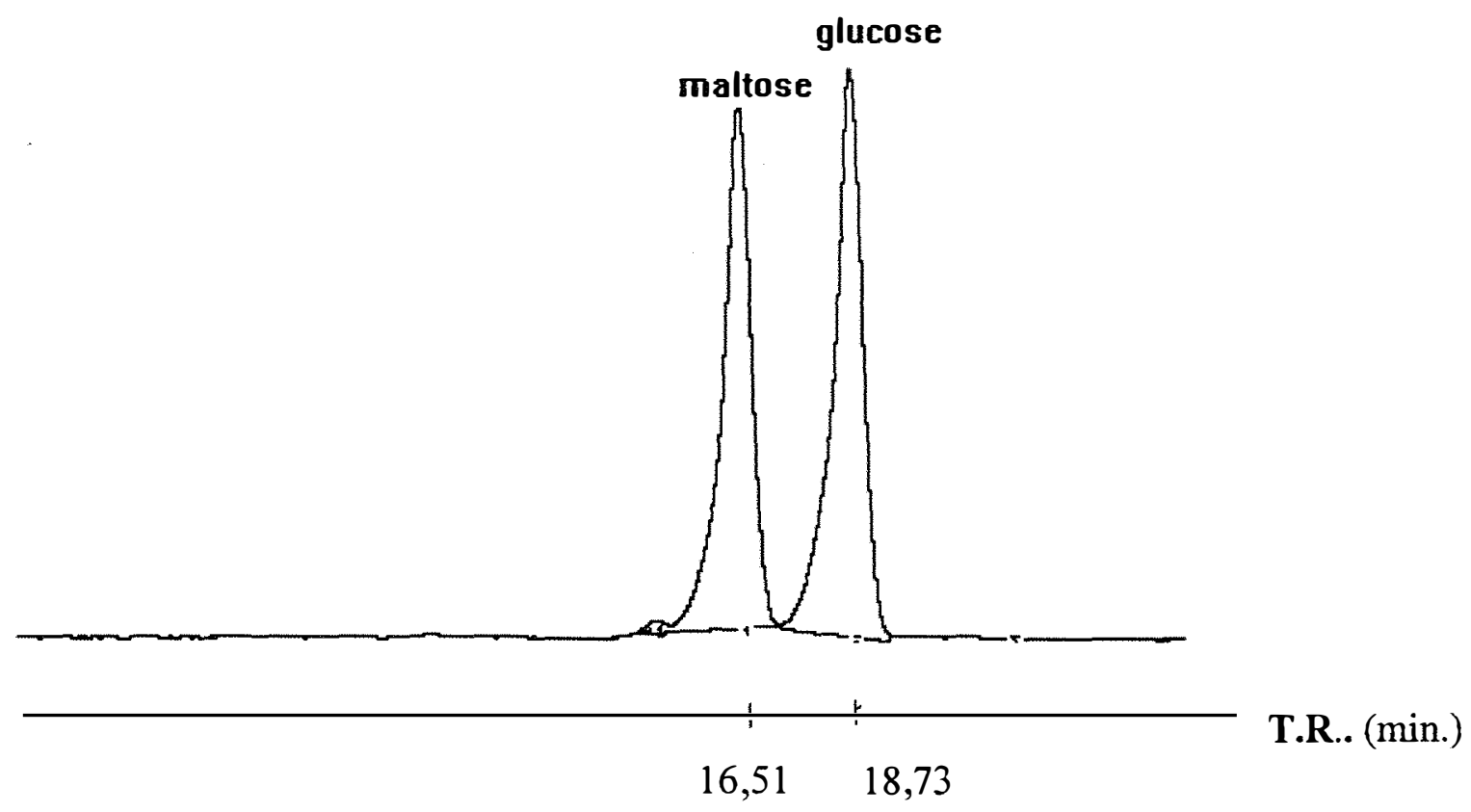

Figura 18.Cromatograma padrão de maltose e glicose. 
Observando-se o cromatograma de fécula de mandioca hidrolisada com $\alpha$ amilase (Fig. 19), nota-se que o tempo de retenção de dextrinas lineares com grau de polimerização (DP) de 7-6 coincidem com o tempo de retenção de $\alpha$-CDs (Fig. 17). Já os picos referentes à maltose $(\mathrm{TR}=16,47)$ e glicose $(\mathrm{TR}=18,66)$ (Fig.18), coincidem com o pico referente à $\chi$-CDs (Fig.17). Em razão destes resultados, adotou-se submeter as amostras resultantes da reação de produção de CDs, à hidrólise com $\beta$-amilase, para eliminar a interferência de dextrinas lineares sem degradar CDs (ALVAREZ et al. 1994).

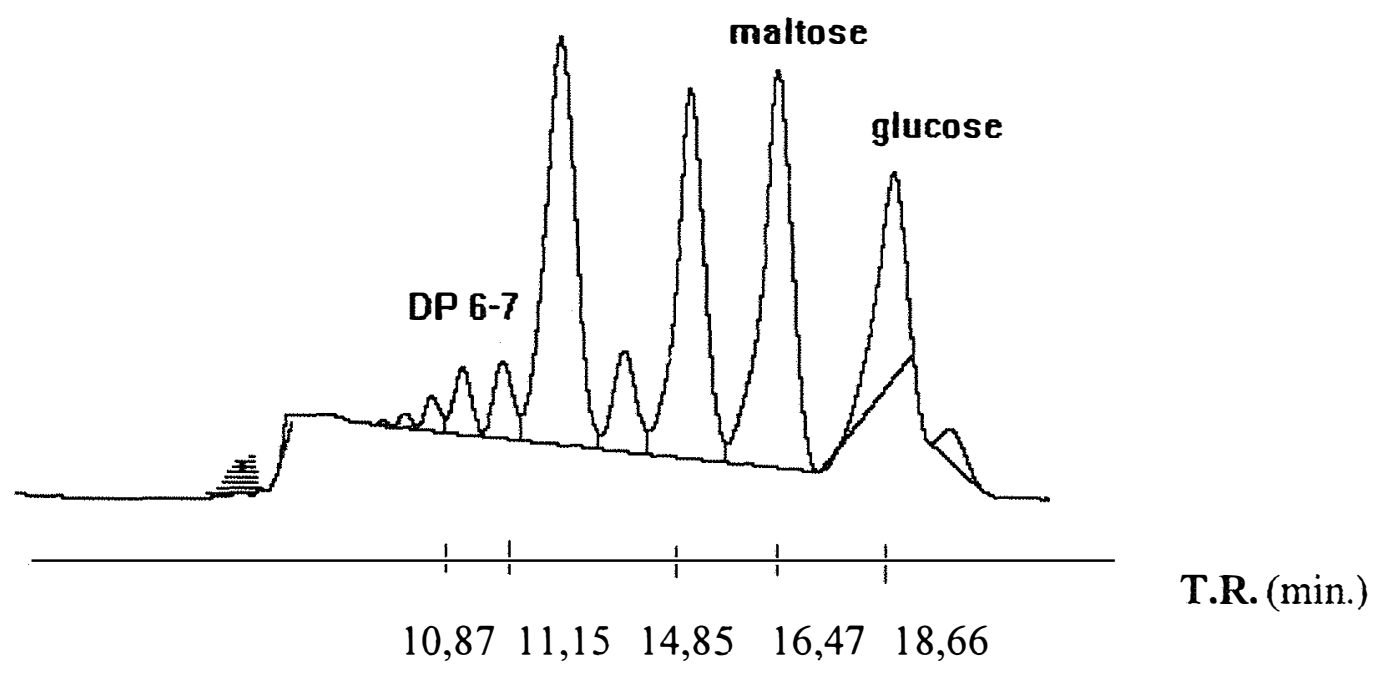

Figura 19. Cromatograma de hidrolisado de fécula de mandioca com $\alpha$-amilase.

Na Fig.20, referente aos hidrolisados de fécula com CGTase, foram observados picos próximos à 6-7 minutos, identificados como sendo relativos às cadeias longas de amido, que sofreram pouca ou nenhuma ação da enzima. Os picos com tempo de retenção próximos a 11,20 minutos são referentes às $\alpha$-CDs e às dextrinas lineares com DP 6-7, enquanto que os picos com tempos de retenção de 24,81 correspondem à $\beta$-CDs. 
Foi porém observado pico com tempo de retenção de 20,80-21,11 minutos, o qual não correspondeu a nenhum dos padrões analisados.

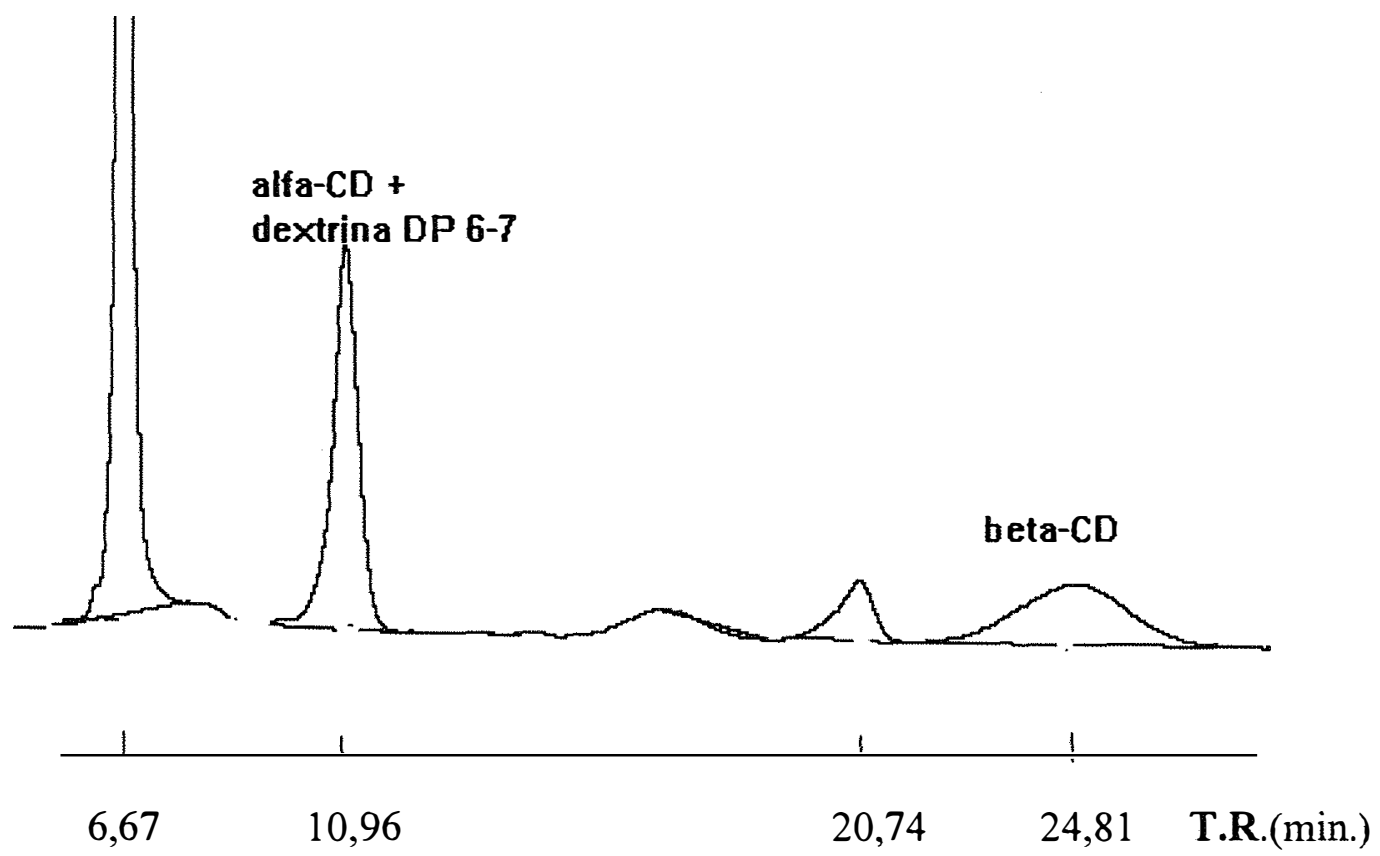

Figura 20. Cromatograma relativo à fécula de mandioca após hidrólise com CGTase.

Reações de CGTase com amilose e amilopectina foram realizadas com o objetivo de verificar se o pico com tempo de retenção de 20,80-21,11 minutos correspondia à CDs ramificadas, provenientes da ação da CGTase em amilopectina. Entretanto, perfis semelhantes foram observados para reação com CGTase quando se empregou amilopectina e amilose como substratos (Fig.21 e 22). 


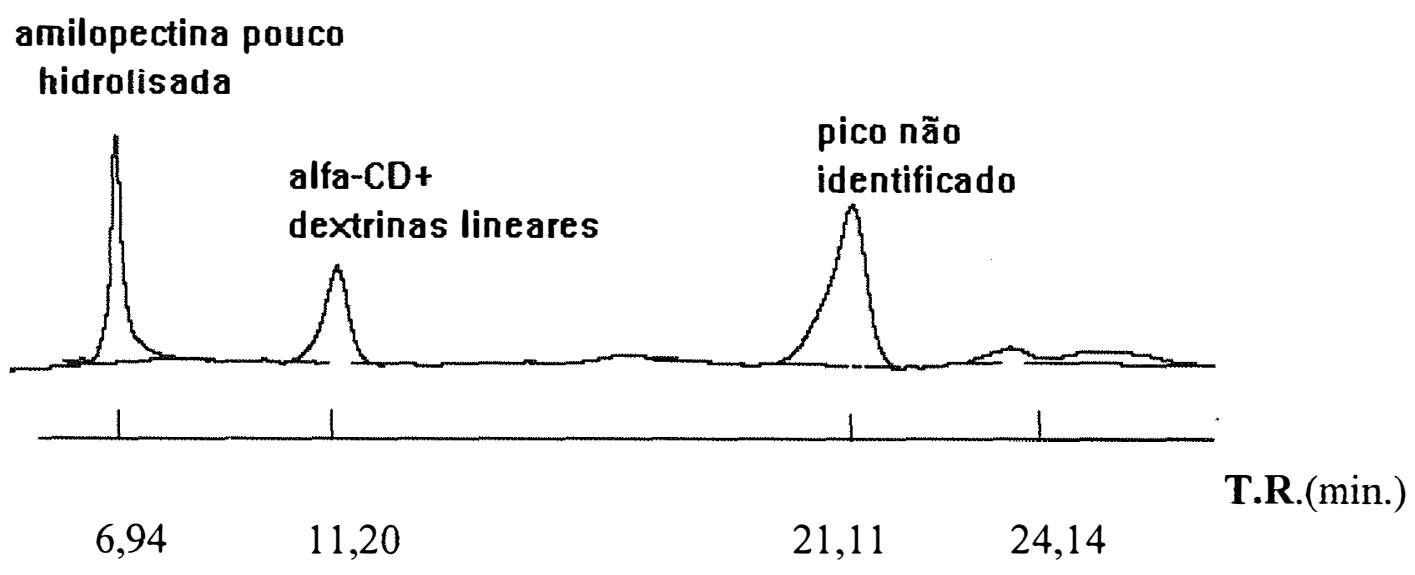

Figura 21.Cromatograma referente à amilopectina hidrolisada com CGTase.

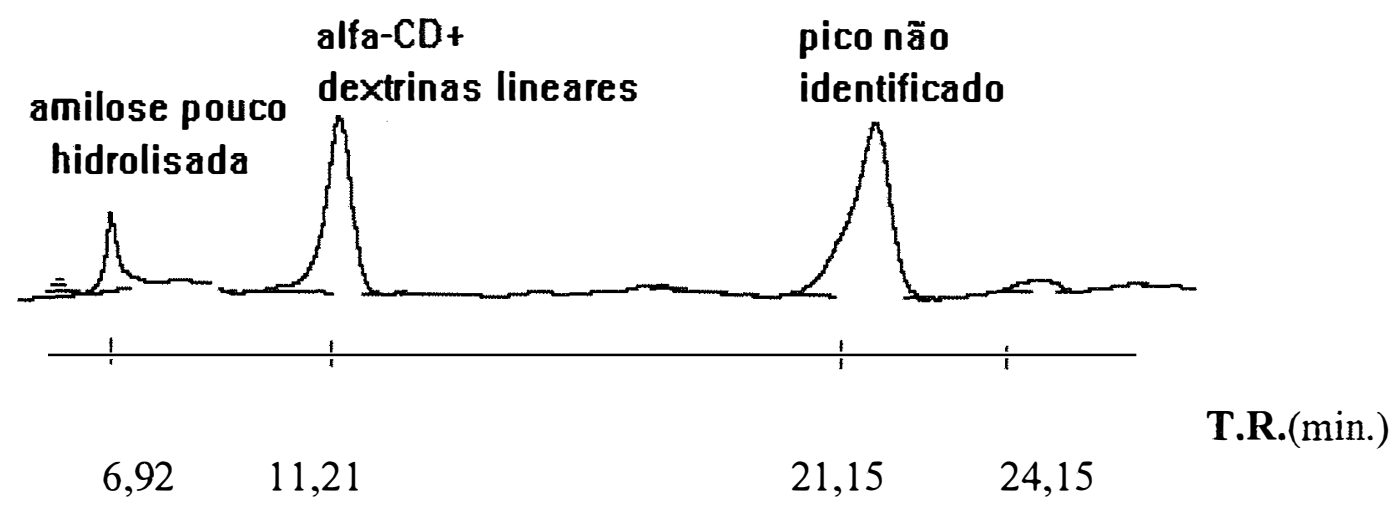

Figura 22. Cromatograma referente à amilose hidrolisada com CGTase.

A partir destes dados, deduz-se que estes picos não referem-se à CDs ramificadas, pois estão presentes tanto em reações feitas com amilose como em amilopectina. Uma provável hipótese é que sejam referentes aos resíduos da CGTase desnaturada, visto que não são observados em hidrolisados com $\alpha$-amilase (Fig.23) ou celulase (Fig.24). A diferença de área dos picos provavelmente deve-se à menor solubilização da amilopectina quando comparada à amilose, sendo necessário a adição de $\mathrm{NaOH}$ e de maior quantidade de CGTase para que a solubilização da amilopectina fosse possível. 


\subsection{Pré tratamentos do farelo}

O tratamento prévio do farelo foi feito visando a seleção da enzima adequada para liquefação inicial. Foram observadas diferenças entre o perfil do farelo liqüefeito com celulase, $\alpha$-amilase e CGTase (Figs. 23, 24, e 25). Utilizando-se $\alpha$-amilase, a produção de dextrinas lineares de DP 3 a 7 foi maior que para as demais enzimas. A liquefação de farelo com celulase também possibilitou a formação de dextrinas lineares com diferentes tamanhos, enquanto que a liquefação do farelo com CGTase formou dextrinas lineares de DP 6-7, as quais serão usadas posteriormente para síntese de $\alpha$ CDs.
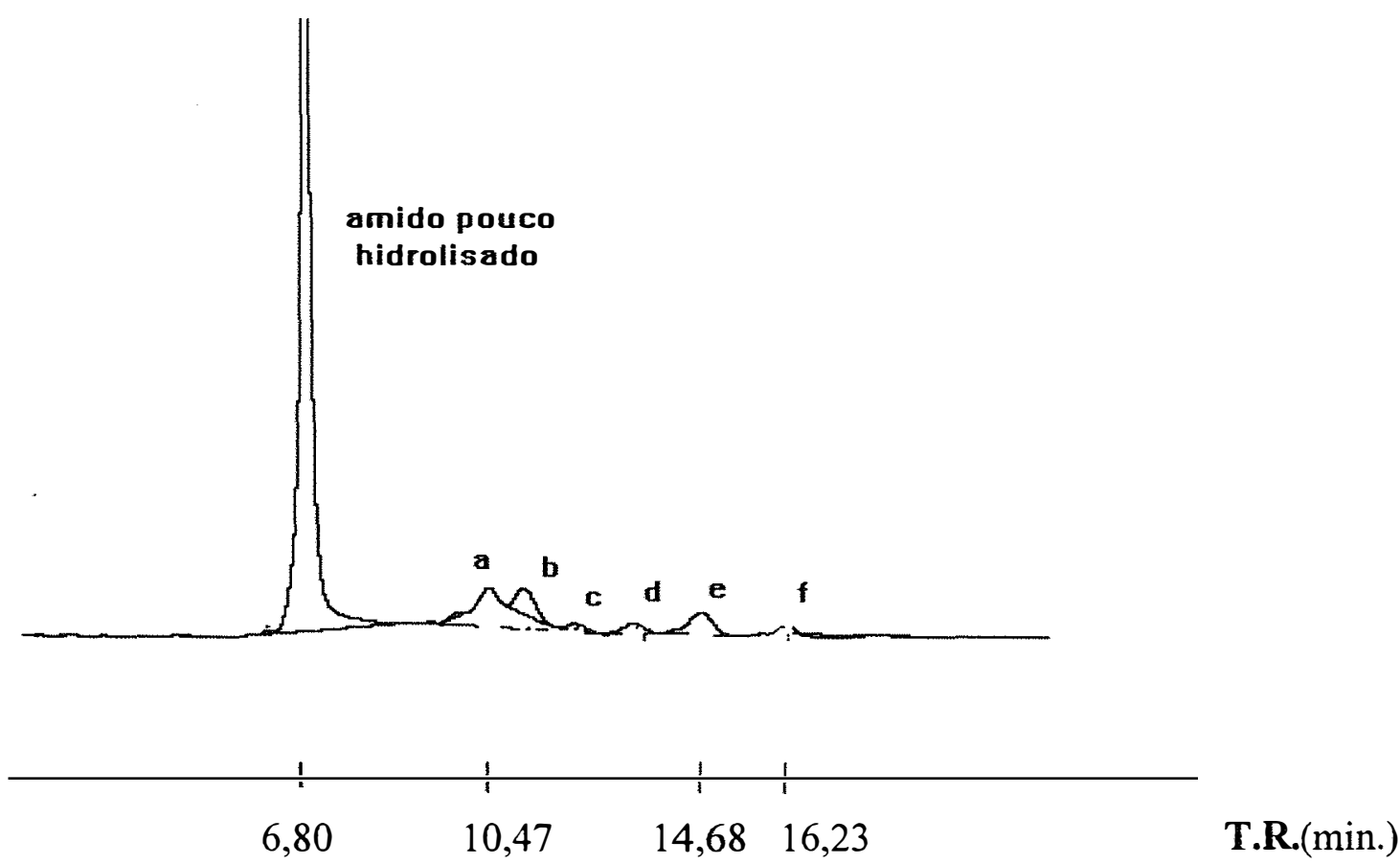

Figura 23. Cromatograma referente ao farelo liqüefeito com $\alpha$-amilase, mostrando amido pouco hidrolisado e dextrinas de diferentes graus de polimerização (pontos a a f). 


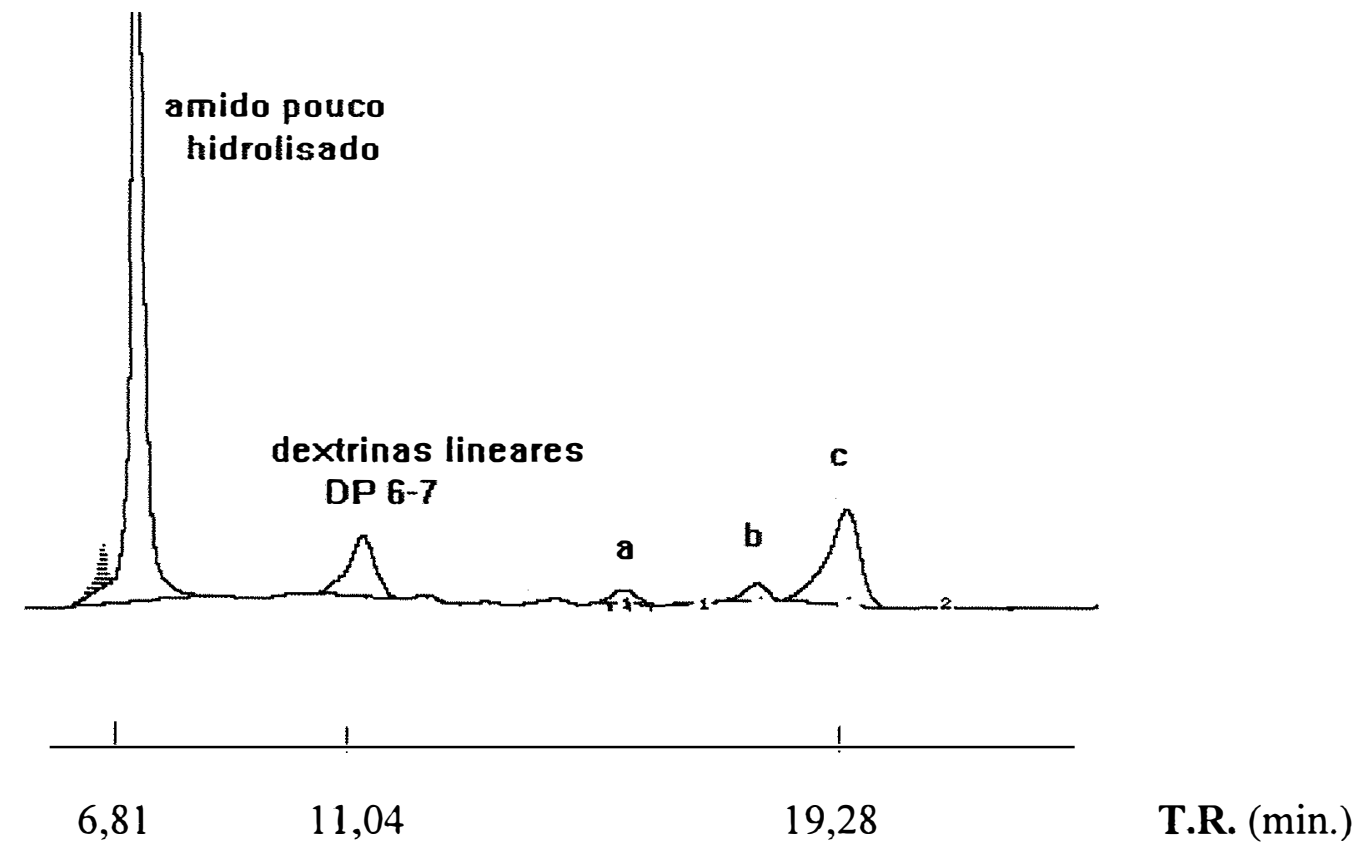

Figura 24. Cromatograma referente ao farelo liqüefeito com celulase mostrando amido pouco hidrolisado e dextrinas de diferentes graus de polimerização (pontos a a c).

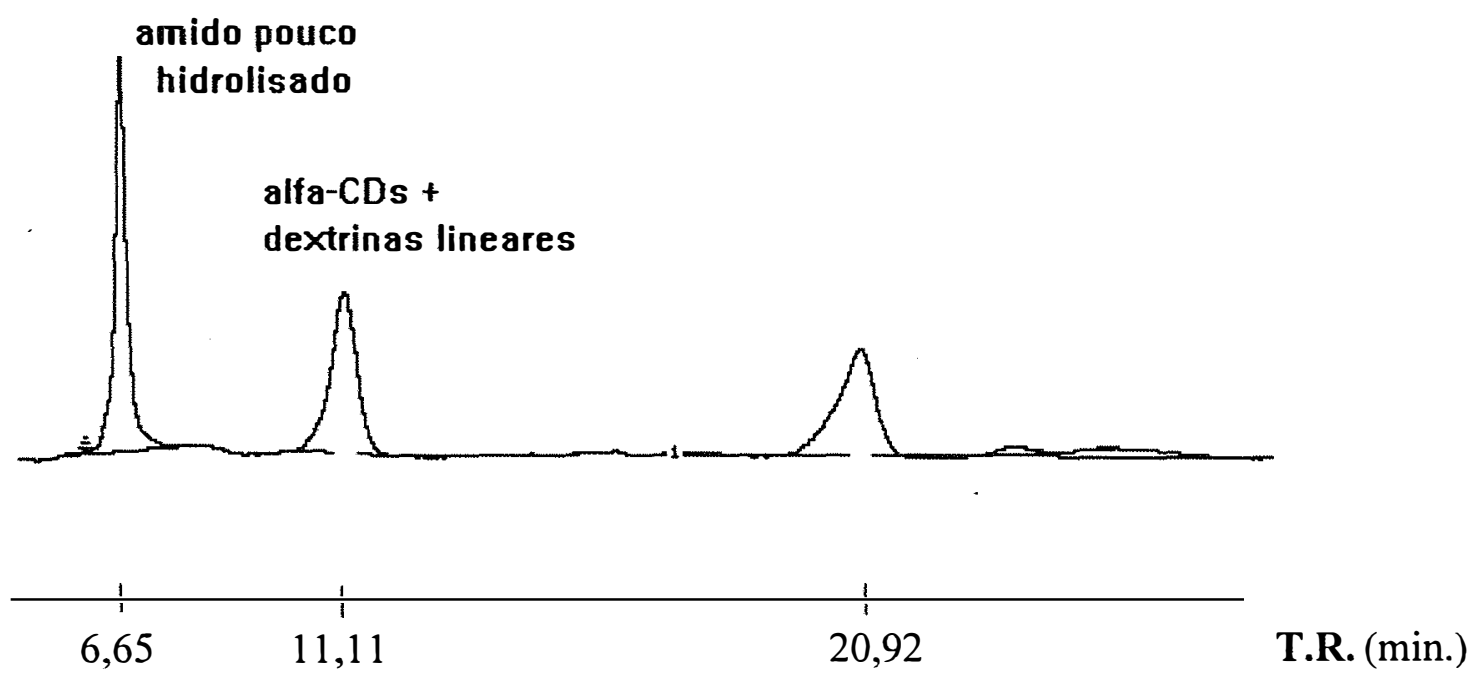

Figura 25. Cromatograma referente ao farelo liqüefeito com CGTase.

As diferenças dos perfis de hidrolisados do farelo foram acentuadas após a reação com CGTase, indicando que a ação da CGTase resulta em produtos distintos de acordo com o grau de liquefação do amido. 


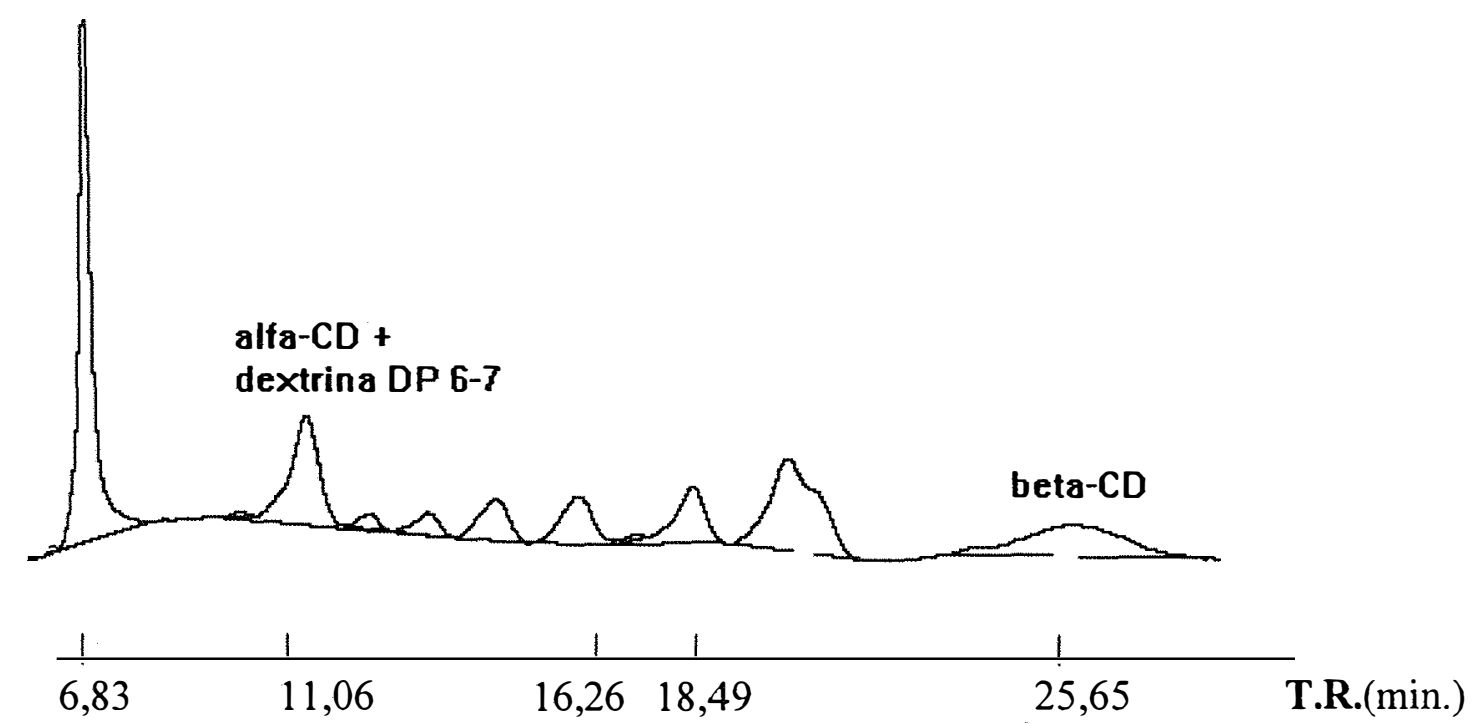

Figura 26. Cromatograma do farelo liqüefeito com celulase e incubado com CGTase durante 6 horas.

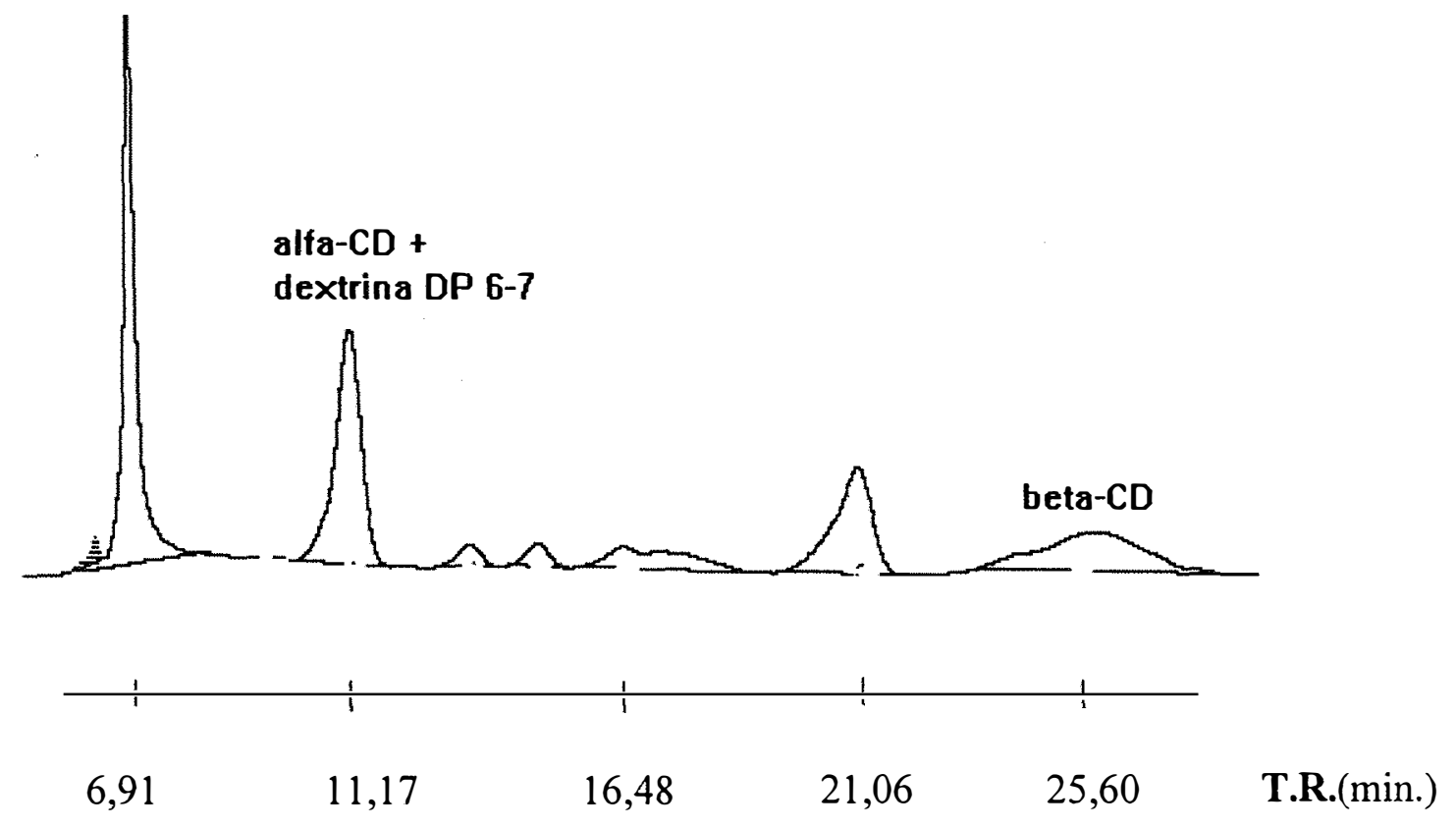

Figura 27. Cromatograma do farelo liqüefeito com $\alpha$-amilase e incubado com CGTase durante 6 horas. 
Analisando os cromatogramas (Fig.26 e 27) observa-se que a liquefação prévia do farelo com celulase ou $\alpha$-amilase não aumentou a produção de $\beta-C D$, pois propicia a formação de dextrinas lineares de tamanhos que não são adequados para a ciclização (KOBAYASHI et al., 1983; BENDER, 1981 a). Observando ainda os cromatogramas relativos às amostras que sofreram ação da $\beta$-amilase após a produção de CDs (Fig. 28, 29 e 30), verifica-se que praticamente não houve diferença entre a quantidade de $\beta-C D$ produzida, enquanto ocorreu maior produção de $\alpha$-CDs com farelo liqüefeito com CGTase. Após a ação da $\beta$-amilase nota-se também maior produção de maltose $(\mathrm{TR}=16.25)$ para farelo liqüefeito com $\alpha$-amilase e com celulase, quando comparada a solução de farelo liqüefeito com CGTase. Estes resultados vão de encontro aos obtidos por KIM et al. (1993), que verificaram que a produção de CDs a partir de amido de milho não liqüefeito foi similar à produção feita a partir de amido liqüefeito.

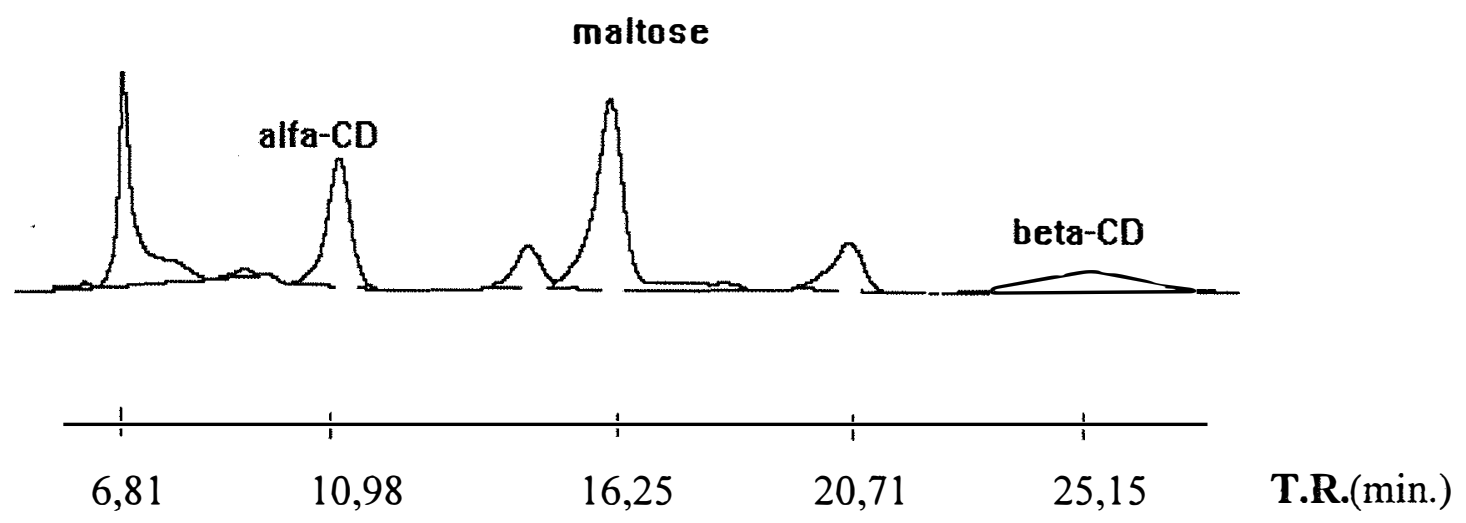

Figura 28. Cromatograma do farelo liqüefeito $\operatorname{com} \alpha$-amilase e tratado $\operatorname{com} \beta$-amilase após a reação com CGTase. 


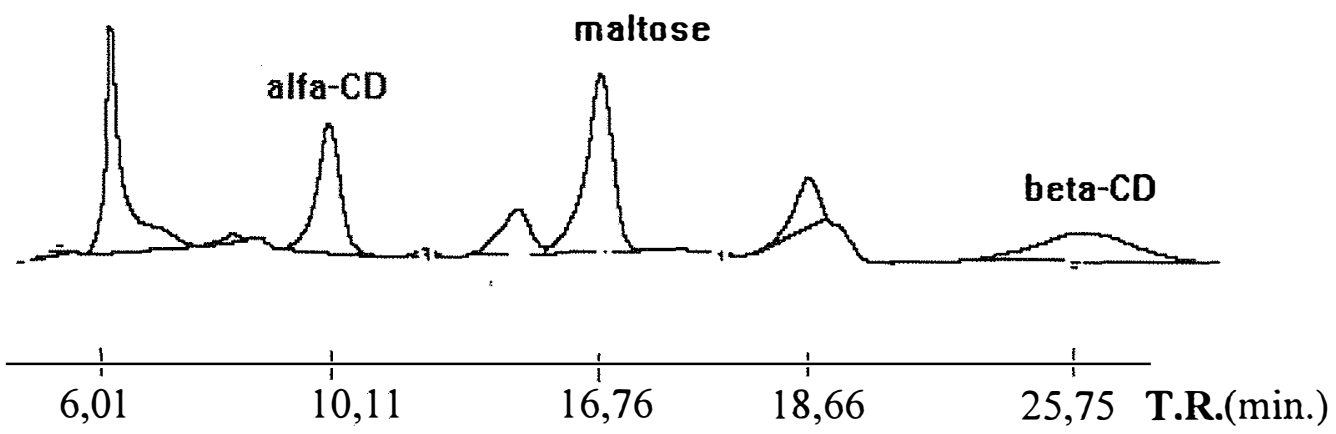

Figura 29. Cromatograma do farelo liqüefeito com celulase e tratado com $\beta$-amilase após reação com CGTase.

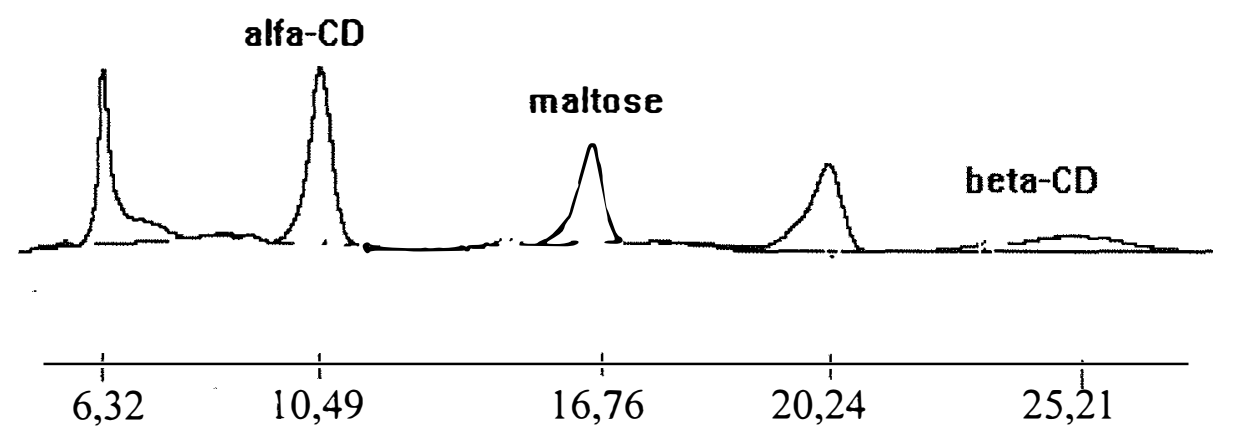

T.R.(min.)

Figura 30. Cromatograma do farelo liqüefeito com CGTase e tratado com $\beta$-amilase após reação com CGTase.

A média das três repetições para produção de $\alpha$-CDs, quando se empregou celulase como enzima de liquefação foi de $2,10 \mathrm{mg} / \mathrm{ml}$, enquanto para liquefação com CGTase foi $2,16 \mathrm{mg} / \mathrm{ml}$ e com $\alpha$-amilase foi $2,09 \mathrm{mg} / \mathrm{ml}$. Para produção de $\beta$-CDs a partir de farelo liqüefeito com celulase, o valor obtido foi $1,32 \mathrm{mg} / \mathrm{ml}$, enquanto que para farelo liqüefeito com CGTase foi de $1,23 \mathrm{mg} / \mathrm{ml}$ e para $\alpha$-amilase foi $1,20 \mathrm{mg} / \mathrm{ml}$. Conforme se observa nos cromatogramas das Figuras 28, 29 e 30, após reação com $\beta$ - 
amilase, os perfis das reações, independente da enzima empregada na liquefação ( $\alpha$ amilase, celulase e CGTase), se assemelharam. Este fato deve-se à hidrólise das dextrinas lineares de tamanhos intermediários em maltose, realizada pela enzima $\beta$ amilase. Baseado nestes dados, a CGTase foi escolhida como enzima de liquefação do farelo para as próximas etapas do experimento.

\subsection{Produção de CDs}

\subsubsection{Produção de $\alpha$-CDs}

Os resultados revelam que a produção de $\alpha$-CDs, tanto a partir de fécula como de farelo, apresentou máximo após duas horas de reação (Figura 31). O Teste de Tuckey mostra que apenas o tempo tl (liquefação) diferiu dos demais tempos (Tabela 12). A análise estatística mostrou que, para a produção de $\alpha$-CDs, não houve diferença significativa entre os tratamentos de fécula e farelo (Tabela 13). Também não houve interação $\mathrm{T} \times \mathrm{t}$.

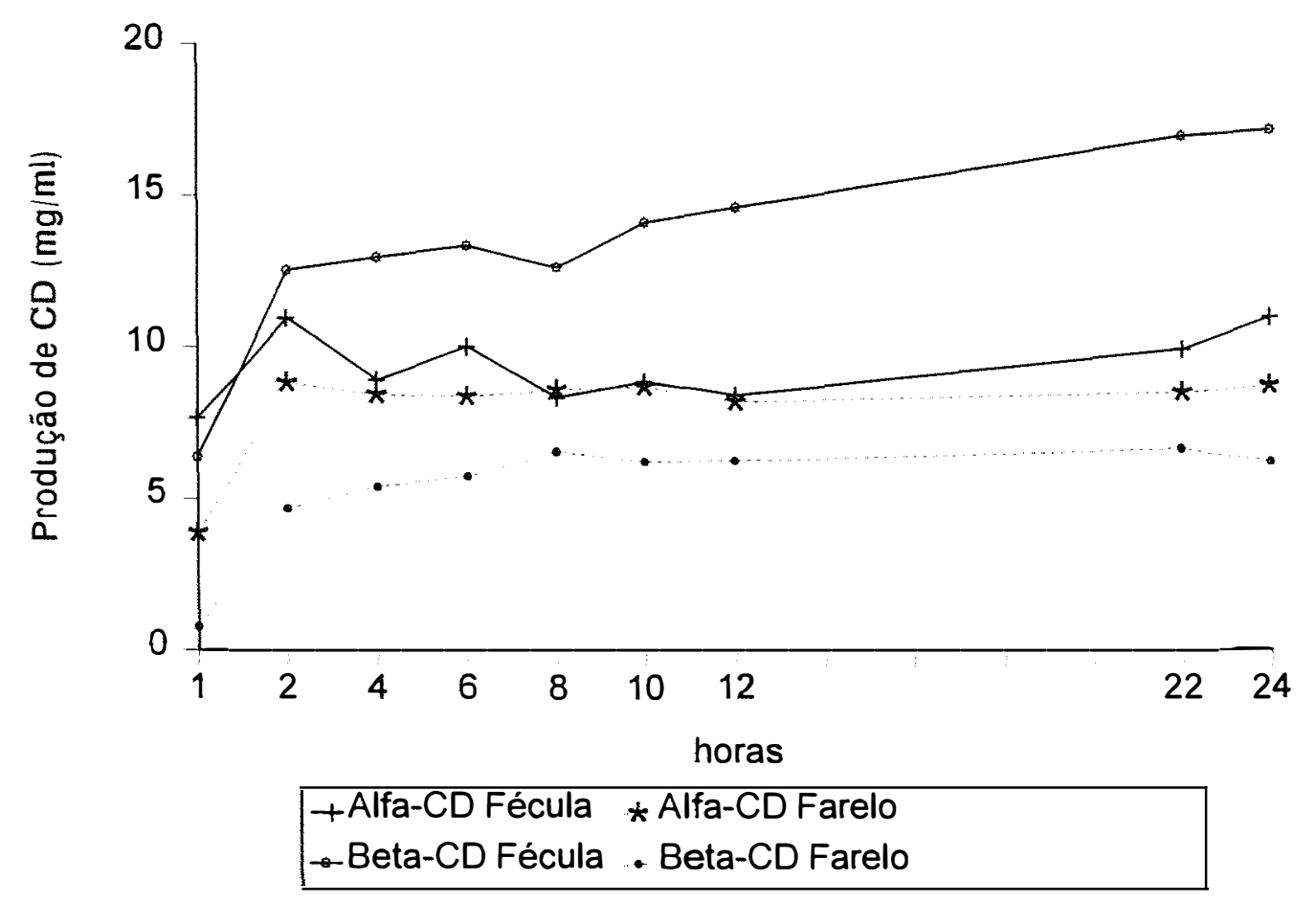

Figura 31. Produção de $\alpha$ e $\beta$-CDs durante 24 horas, usando fécula e farelo como substratos. 
Na figura acima observa-se que o máximo de produção ocorreu após duas horas de reação, tanto para fécula como para farelo. A variação da produção ao longo do tempo antes de atingir um patamar talvez possa ser atribuída às reações de transglicolisação e acoplamento, ocorridas na presença de aceptores (glicose e maltose) e paralelamente à reação de ciclização.

\subsubsection{Produção de $\beta$-CDs}

Observou-se que a produção de $\beta$-CDs foi maior quando se usou fécula como substrato (Fig. 31). A análise estatística mostrou que houve diferença significativa ao nível $\alpha=0,05$ entre os tratamentos fécula e farelo (parcelas T1 e T2) (Tabela 13) e entre os tratamentos relativos aos tempos (subparcelas) (Tabela 12). O Teste de Tuckey revela que tempo $\mathrm{t} 1$ difere dos demais tempos, porém que os tempos t 2 e $t 4$ não diferem entre si mas diferem de $\mathrm{t} 24$. O tempo $\mathrm{t} 24$ não apresenta diferença dos tempos t6, t8, t10, t12 e t22 (Tabela 12). Não foi observada interação T x t.

Ao contrário da produção de $\alpha$-CDs, a produção de $\beta$-CDs diferiu significativamente em relação aos substrato usado (Tabela 13). Quando se usou fécula como substrato, a produção de $\beta$-CD foi superior para todos os tempos (Fig. 31). Após 24 horas de reação, a proporção $\alpha$ : $\beta$-CDs no caso de farelo foi de 1,5: 1,0; enquanto que da fécula foi de 1,0:1,45.

Estas proporções estão de acordo com KITAHATA e OKADA (1974), que relataram que a CGTase proveniente do B. macerans produz preferencialmente $\alpha-C D$. Segundo NORMAN e JØRGENSEN (1992), a CGTase do B. macerans produz uma proporção de 2,1:1,0:1,0 de $\alpha: \beta: \chi$-CDs. Entretanto RENDLEMAN (1993) afirma que estas proporções relativas podem variar consideravelmente de acordo com as condições de reação.

A conversão de amido em $\alpha$-CDs foi de $19 \%$ para a fécula e $27 \%$ para o farelo. Para $\beta$-CDs, os valores foram de $21 \%$ para fécula e $15 \%$ para o farelo. Estes resultados concordam com os obtidos por NAKAMURA e HORIKOSHI (1976), que afirmam que 
após 60 minutos de incubação $25-30 \%$ do amido foi convertido em CDs e que a concentração e a natureza do substrato alteram consideravelmente tais valores.

\subsubsection{Comparação entre produção de CDs usando farelo e fécula como substratos}

Durante as primeiras horas de reação com CGTase as diferenças no perfil de hidrólise entre fécula e farelo não foram acentuadas. As diferenças aumentaram com o tempo de reação, quando se constatou presença de picos referentes às dextrinas lineares no caso da fécula (Fig. 33), mas não se observou tais picos para farelo (Fig. 32). Tal resultado ressalta, mais uma vez a maior disponibilidade de amido presente na fécula, facilitando sua hidrólise.

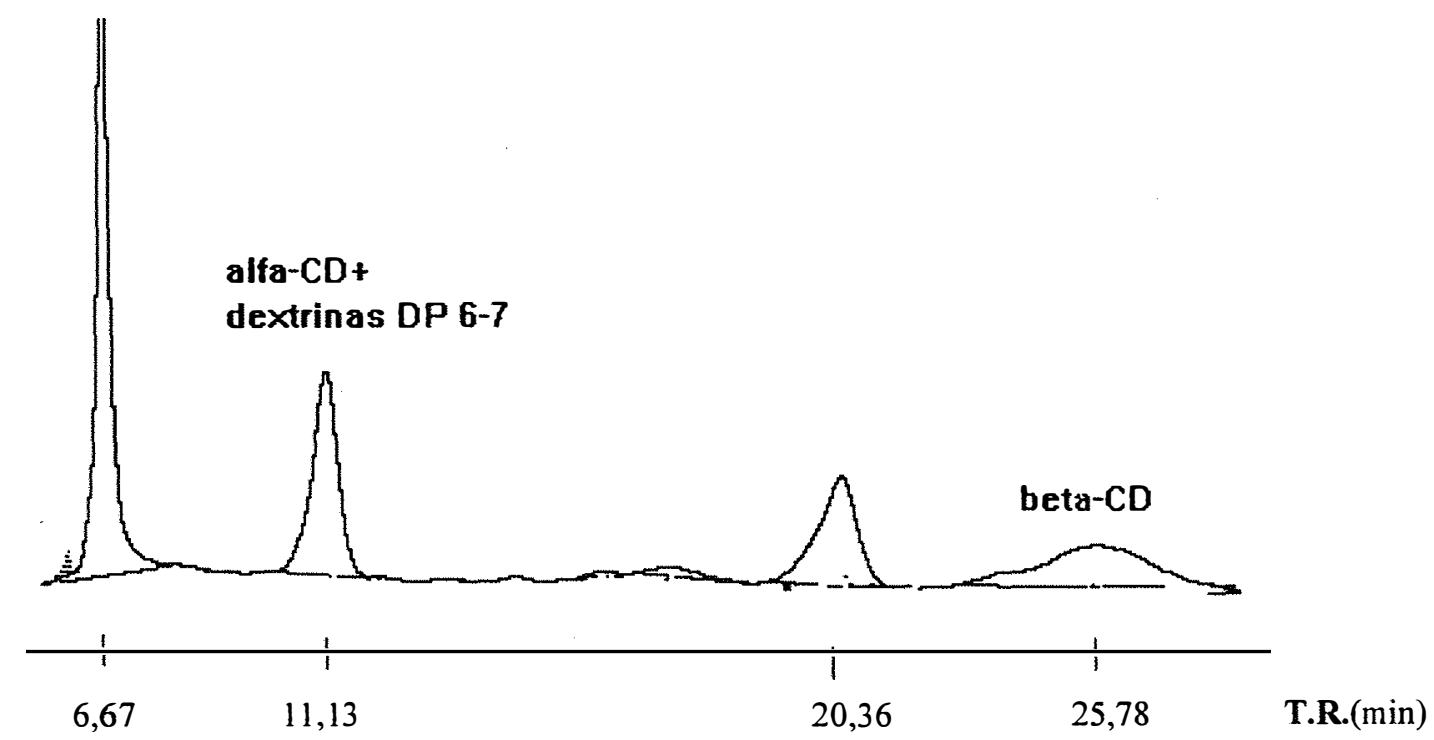

Figura 32. Perfil do hidrolisado de farelo após 24 horas de reação com CGTase. 


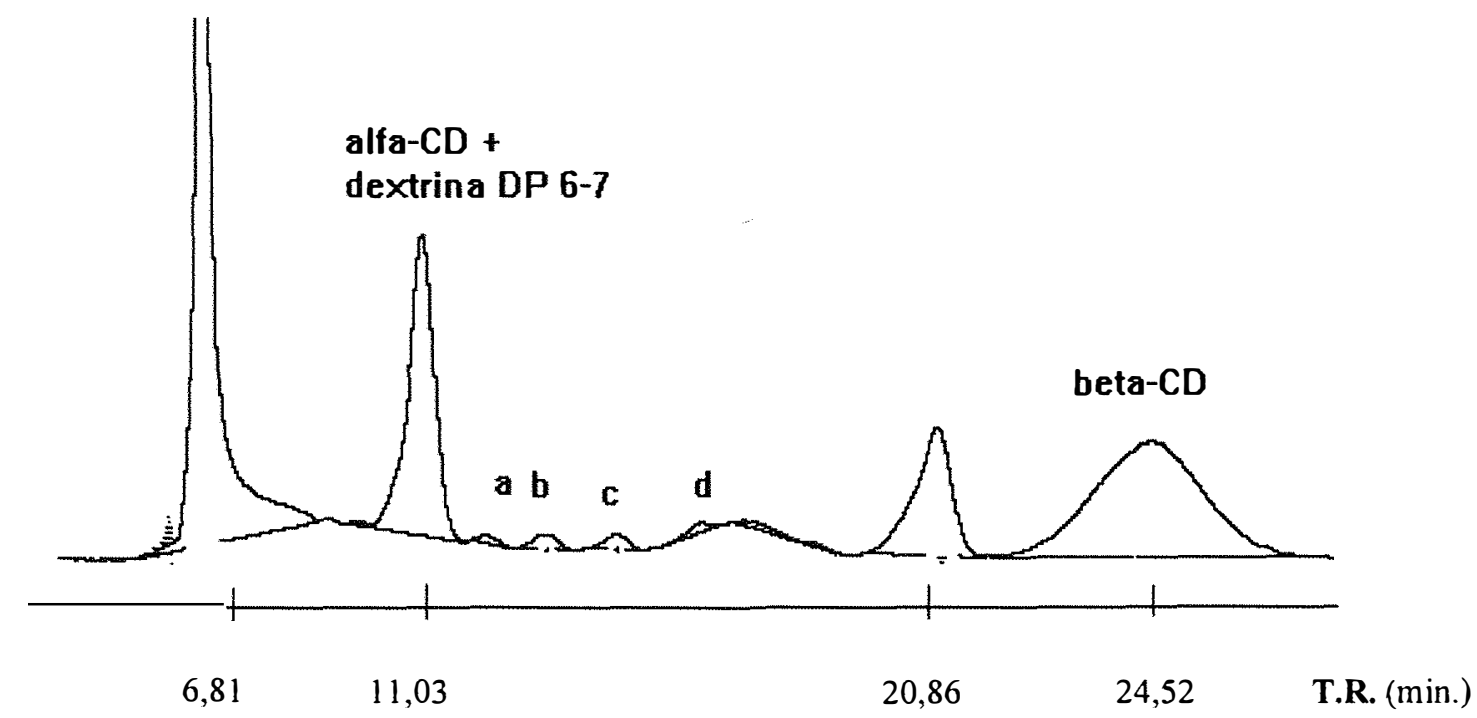

Figura 33. Perfil do hidrolisado de fécula após 24 horas de reação com CGTase, com dextrinas de diferentes grau de polimerização (pontos a a d).

A ação da $\beta$-amilase sobre a suspensão hidrolisada com CGTase, leva a formação de maltose a partir de dextrinas de DP 6-7 e de cadeias longas de amido (Fig. 34). No caso da fécula, a $\beta$-amilase hidrolisa as dextrinas de DP 6-7 e as cadeias longas de amido, resultando maltotriose e principalmente maltose (Fig. 35).

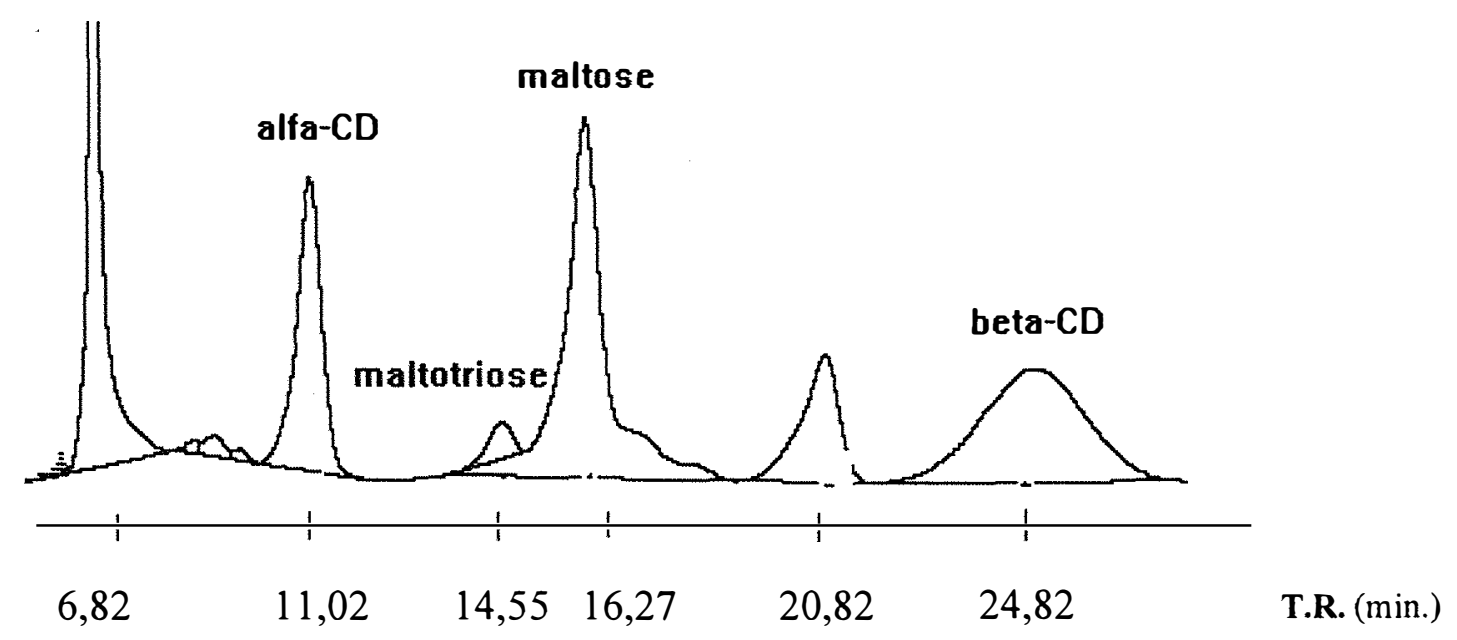

Figura 34. Perfil do hidrolisado de fécula, após 24 horas de reação com CGTase quando submetidas à ação de $\beta$-amilase 


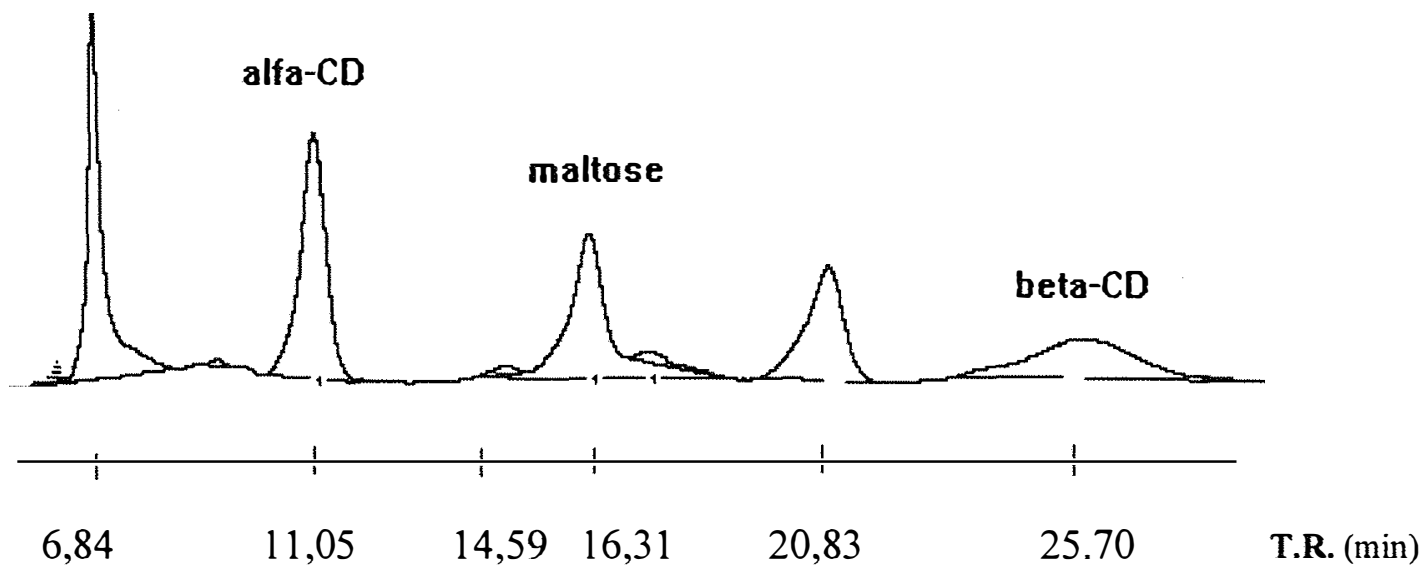

Figura 35. Perfil do hidrolisado do farelo, após 24 horas de reação com CGTase quando submetidas à ação de $\beta$-amilase

Devido à mudanças nos perfis, promovidas pela adição de $\beta$-amilase, a identificação dos picos referentes à $\alpha$-CDs é facilitada, uma vez que as dextrinas lineares de DP 6-7 são hidrolisadas em cadeias menores. 
Tabela 12. Comparação da produção de CDs, extremidades redutoras e amido residual. Médias dos diferentes tempos de reação (tratamentos das subparcelas) através do Teste de Tuckey $(\alpha=0,05)$.

\begin{tabular}{|c|c|c|c|c|}
\hline \multirow{2}{*}{$\begin{array}{l}\text { Tempo } \\
\text { (horas) }\end{array}$} & \multicolumn{2}{|c|}{ Produção de CDs (mg/ml) } & \multirow[b]{2}{*}{$\begin{array}{c}\text { Extremidade } \\
\text { redutora } \\
(\mathrm{mg} / \mathrm{ml}) \\
(\mathrm{DMS}=0,43)\end{array}$} & \multirow[b]{2}{*}{$\begin{array}{c}\text { Amido não } \\
\text { hidrolisado } \\
(\mathrm{mg} / \mathrm{ml}) \\
(\mathrm{DMS}=0,30)\end{array}$} \\
\hline & $\begin{array}{c}\alpha-C D \\
(\mathrm{DMS}=1,92)\end{array}$ & $\begin{array}{c}\beta-C D \\
(D M S=2,57)\end{array}$ & & \\
\hline Liquefação & $5,77^{b}$ & $3,58^{\mathrm{d}}$ & $0,99^{\mathrm{c}}$ & $5,21^{\mathrm{a}}$ \\
\hline 2 & $9,89^{\mathrm{a}}$ & $8,60^{\mathrm{c}}$ & $1,93^{b}$ & $0,26^{b}$ \\
\hline 4 & $8,68^{a}$ & $9,20^{b c}$ & $2,25^{a}$ & $0,31^{\mathrm{b}}$ \\
\hline 6 & $8,85^{a}$ & $9,56^{a b c}$ & $2,42^{a b}$ & $0,25^{b}$ \\
\hline 8 & $8,47^{\mathrm{a}}$ & $9,74^{a b c}$ & $2,16^{\mathrm{ab}}$ & $0,34^{b}$ \\
\hline 10 & $8,79^{a}$ & $10,20^{a b c}$ & $2,19^{\mathrm{ab}}$ & $0,33^{b}$ \\
\hline 12 & $8,87^{\mathrm{a}}$ & $10,45^{a b c}$ & $2,36^{\mathrm{ab}}$ & $0,36^{b}$ \\
\hline 22 & $9,24^{\mathrm{a}}$ & $11,79^{a b}$ & $2,51^{\mathrm{a}}$ & $0,30^{b}$ \\
\hline 24 & $9,63^{a}$ & $11,74^{a b}$ & $2,24^{\mathrm{ab}}$ & $0,35^{b}$ \\
\hline
\end{tabular}

* Médias com a mesma letra não diferem significativamente.

Tabela 13. Comparação entre substratos fécula e farelo na produção de CDs. Médias finais dos tratamentos das parcelas Fécula e Farelo para comparações pelo Teste de Tuckey $(\alpha=0,05)$.

\begin{tabular}{ccccc}
\hline \multirow{2}{*}{$\begin{array}{c}\text { Substra } \\
\text { tos }\end{array}$} & $\begin{array}{c}\text { Produção de CDs }(\mathrm{mg} / \mathrm{ml}) \\
\text { ny }\end{array}$ & $\begin{array}{c}\beta-\mathrm{CD} \\
(\mathrm{DMS}=4,26)\end{array}$ & $\begin{array}{c}\text { Extremidade } \\
\text { redutora } \\
(\mathrm{mM} / \mathrm{ml})\end{array}$ & $\begin{array}{c}\text { Amido não } \\
\text { hidrolisado } \\
(\mathrm{mg} / \mathrm{ml}) \\
(\mathrm{DMS}=0,19)\end{array}$ \\
\hline Fécula & $9,35^{\mathrm{A}}$ & $13,47^{\mathrm{A}}$ & $2,20^{\mathrm{A}}$ & $0,74^{\mathrm{B}}$ \\
Farelo & $8,03^{\mathrm{A}}$ & $5,40^{\mathrm{B}}$ & $2,03^{\mathrm{B}}$ & $0,98^{\mathrm{A}}$ \\
\hline
\end{tabular}

* Médias com a mesma letra não diferem significativamente.

A Tabela 14 mostra os resultados referentes às médias das três repetições das amostras analisadas quanto às extremidades redutoras, amido não hidrolisado e produção de $\alpha$ e $\beta$-CDs ao longo de 24 horas. 
Tabela 14. Valor da produção de CDs, extremidades redutoras e amido residual a partir substratos de fécula e farelo. Médias das três repetições de análises feitas em amostras de reações ao longo de 24 horas.

\begin{tabular}{|c|c|c|c|c|c|c|c|c|}
\hline \multirow{3}{*}{$\begin{array}{c}\text { Tempo } \\
\text { horas }\end{array}$} & \multicolumn{4}{|c|}{ Produção de CDs (mg/ml) } & & & & \\
\hline & \multicolumn{2}{|c|}{$\alpha-C D$} & \multicolumn{2}{|c|}{$\beta-C D$} & \multicolumn{2}{|c|}{$\begin{array}{l}\text { Extremidade } \\
\text { redutora }(\mathrm{mg} / \mathrm{ml})\end{array}$} & \multicolumn{2}{|c|}{$\begin{array}{c}\text { Amido não } \\
\text { hidrolisado } \\
(\mathrm{mg} / \mathrm{ml})\end{array}$} \\
\hline & Fécula & Farelo & Fécula & Farelo & Fécula & Farelo & Fécula & Farelo \\
\hline Liquef. & 7,67 & 3,88 & 6,38 & 0,80 & 0,82 & 1,16 & 5,14 & 5,29 \\
\hline 2 & 10,96 & 8,81 & 12,53 & 4,68 & 1,95 & 2,04 & 0,28 & 0,36 \\
\hline 4 & 8,93 & 8,44 & 12,98 & 5,42 & 2,30 & 2,19 & 0,23 & 0,40 \\
\hline 6 & 10,03 & 8,37 & 13,36 & 5,76 & 2,46 & 2,29 & 0,21 & 0,39 \\
\hline 8 & 8,34 & 8,59 & 12,64 & 6,53 & 2,40 & 2,04 & 0,14 & 0,49 \\
\hline 10 & 8,89 & 8,71 & 14,15 & 6,26 & 2,52 & 1,87 & 0,14 & 0,50 \\
\hline 12 & 9,54 & 8,21 & 14,64 & 6,28 & 2,60 & 2,40 & 0,12 & 0,54 \\
\hline 22 & 9,96 & 8,53 & 17,01 & 6,65 & 2,54 & 2,44 & 0,10 & 0,48 \\
\hline 24 & 10,04 & 8,74 & 17,22 & 6,26 & 2,57 & 2,27 & 0,11 & 0,58 \\
\hline
\end{tabular}

\subsubsection{Extremidades redutoras}

A quantificação das extremidades redutoras reflete o grau de polimerização das dextrinas, sendo o máximo de polimerização equivalente à produção de glicose. Os resultados das análises de quantificação de extremidades redutoras obtidos através de reação com ácido dinitrossalissílico revelam que houve diferença significativa a nível $\alpha$ $=0,05$ entre os tratamentos com fécula e farelo (T1 e T2) (Tabela 13) e entre os tempos de liquefação, t2, t4, t6, t8, t1 0, t12, t22, t24 horas (Tabela 12).

Também foi constatado interação entre tratamento $(\mathrm{T}) \mathrm{x}$ tempo (t). $\mathrm{O}$ desdobramento da interação permitiu verificar que houve diferença entre as médias dos resultados obtidos ao longo do tempo de reação (subparcelas) dentro dos tratamentos de fécula e farelo (parcelas). $\mathrm{O}$ desdobramento dos tratamentos $\mathrm{T} 1$ e T2 (parcelas) dentro do tempo (subparcelas) mostrou que há diferença significativa entre os tempos.

O Teste de Tuckey aplicado nos diferentes tempos permitiu concluir que o tempo t1 (liquefação) diferiu dos demais tempos e que t2, t4, t6, t8, t10, t12, t22 e t24 não 
apresentaram diferença significativa. $\mathrm{O}$ tempo $\mathrm{t} 2$ porém diferiu do tempo t8 e do tempo t4. Para o tempo (subparcelas) dentro do tratamento fécula (parcela T1), t 1 difere dos demais, enquanto que o tempo t2 difere do tempo t12. Para os tratamentos dos tempos (subparcelas) dentro do tratamento farelo (parcelas T2). A análise estatística mostra que t1 difere dos outros tempos. Já os tempos t2, t4 e t6 não apresentam diferença significativa entre si mas diferem do tempo t22.

A Figura 36 ilustra a formação de extremidades redutoras ao longo da reação.

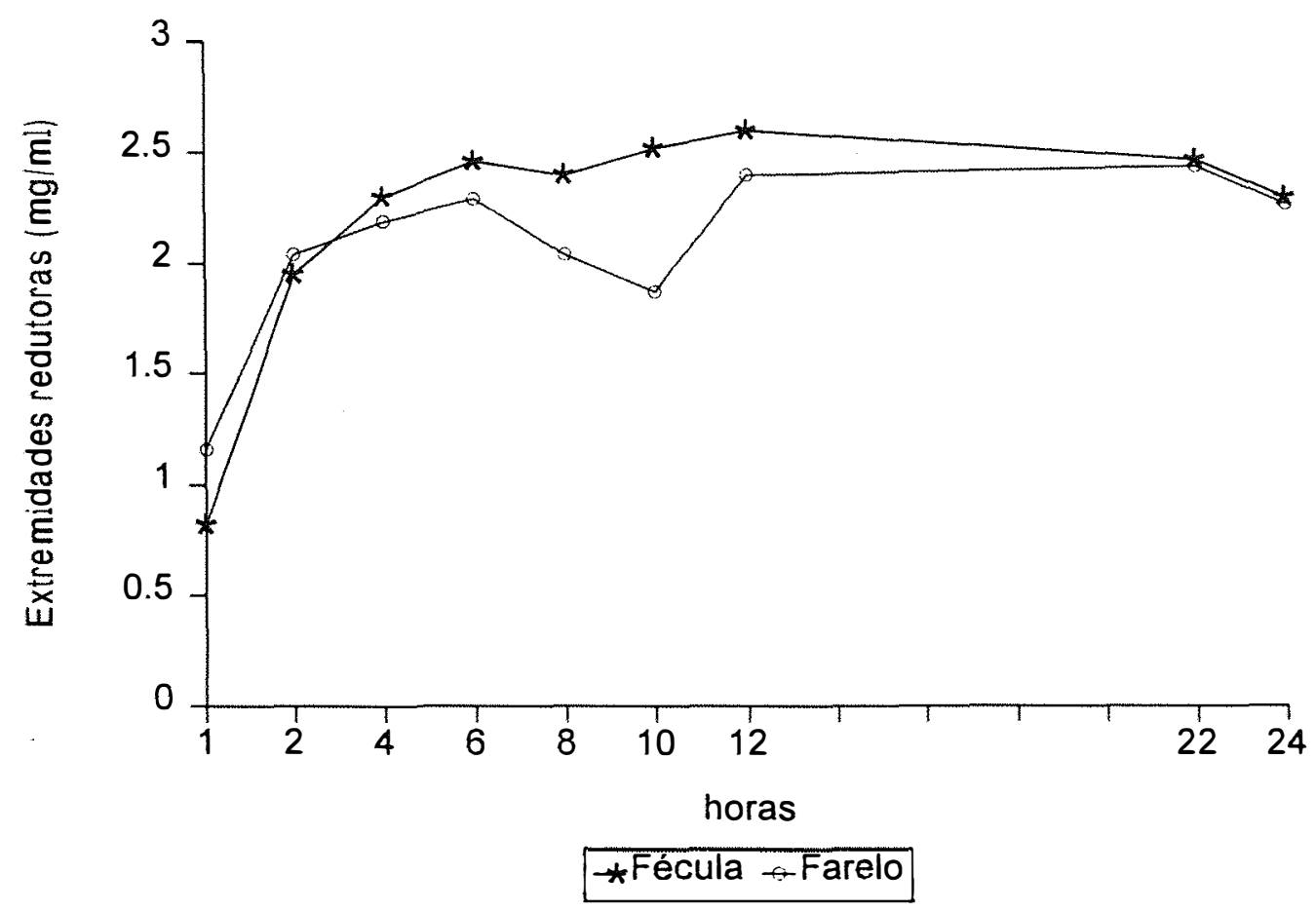

Figura 36. Comparação entre a produção de extremidade redutora ao longo de 24 horas na reação com CGTase, usando fécula e farelo como substratos.

Conforme se observa na Fig. 36, a produção de extremidades redutoras aumentou nas primeiras horas de reação, atingindo posteriormente um patamar. Este perfil reflete que a atividade de hidrólise da CGTase foi maior nas primeiras horas de reação e se manteve constante após 6 horas. Tal fato pode ser devido à perda de atividade enzimática decorrente do tempo de reação ou ao aumento da taxa de ciclização, que 
diminui a quantidade de extremidades redutoras presentes no meio em função da formação de moléculas cíclicas. Devido à estabilização da produção de CDs, provavelmente a primeira hipótese é a mais plausível. A fécula propiciou maior formação de extremidades redutoras, provavelmente devido ao fato de ser um substrato mais facilmente hidrolisado que o farelo, uma vez que neste a concentração de fibras e impurezas é maior, podendo intervir no processo.

\subsubsection{Amido residual}

Conforme indicam os resultados da Tabela 14, a quantidade de amido que não foi hidrolisado ao longo de 24 horas está em torno de $0,11 \mathrm{mg} / \mathrm{ml}$ para fécula e $0,58 \mathrm{mg} / \mathrm{ml}$ para farelo. A análise estatística indica que há diferença significativa entre os tratamentos de fécula e farelo (parcelas T1 e T2) ao nível $\alpha=0,05$ (Tabela 13). Entre os tempos (subparcelas), houve diferença significativa também a $5 \%$, onde apenas o tempo t1 diferiu dos demais tempos (Tabela 12 e Figura 37). Não foi observada interação entre $\mathrm{T} \times \mathrm{t}$.

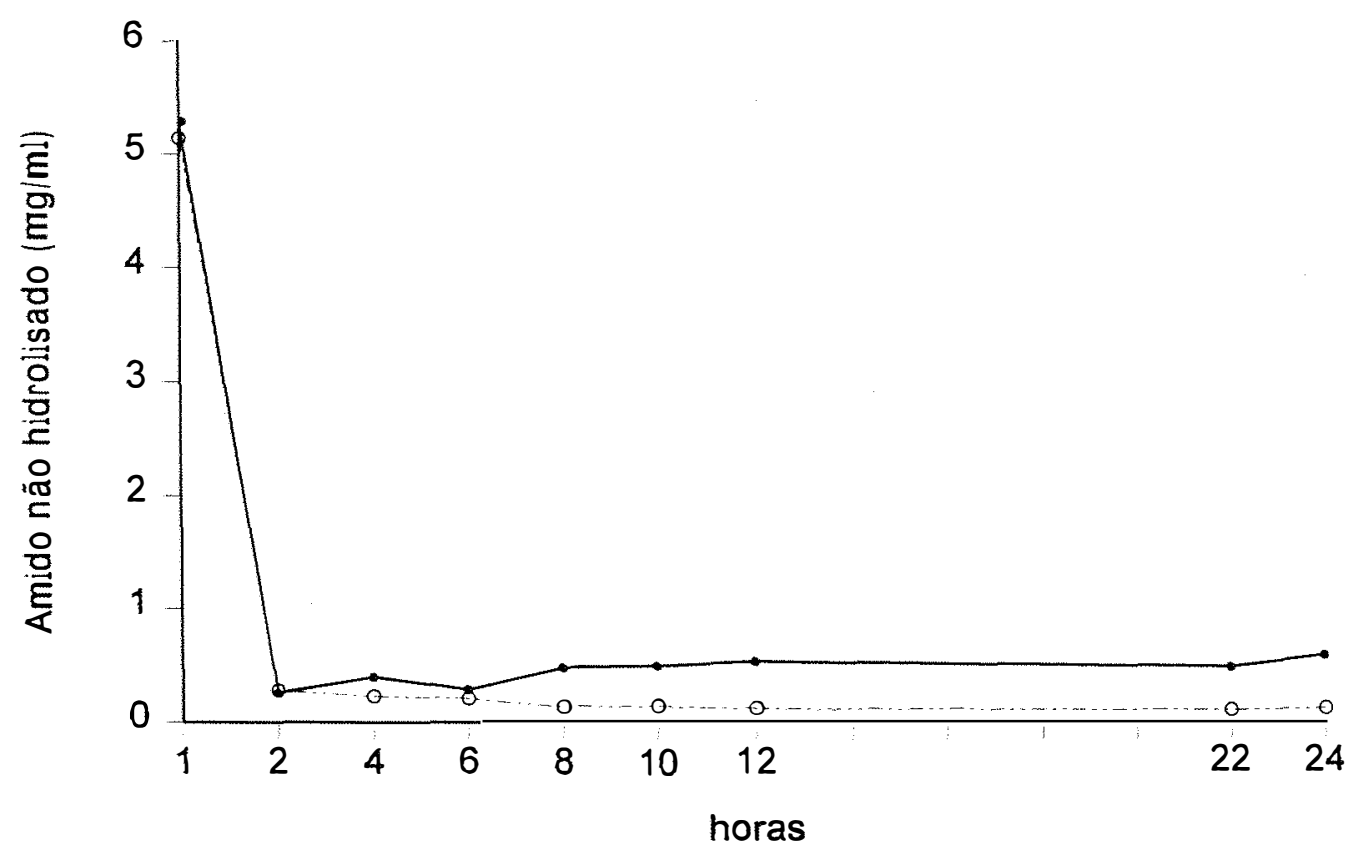

o Fécula $\rightarrow$ Farelo

Figura 37. Amido não hidrolisado pela CGTase ao longo de 24 horas de reação, usando fécula e farelo como substratos. 
Conforme observamos na figura 37, a maior parte do amido é hidrolisado durante as duas primeiras horas de reação, logo após a adição da enzima a $50^{\circ} \mathrm{C}$, concordando com os valores de produção de CDs. Após este período, há praticamente uma estabilização da reação de hidrólise promovida pela CGTase. Estes resultados reforçam as duas hipótese anteriores citadas, relativas à formação de extremidades redutoras. Segundo ABE et al. (1991), a hidrólise do amido promovida pela CGTase é muito pequena quando comparada a reação de transglicosilação, o que concorda com o fato de que a reação de hidrólise, após as primeiras horas, passa a ter menor expressão quando comparada às reações de transglicosilação e ciclização. Nota-se ainda que o perfil da fécula é semelhante ao perfil do farelo (Figura 37), indicando que apesar da quantidade de fibras e impurezas presentes no farelo, a quantidade de amido hidrolisado ao longo do tempo é similar tanto para o farelo como para a fécula.

O mesmo pico de formação de extremidades redutoras observado após duas horas (t2) de reação (Figura 36), hidrólise de amido (Figura 37) e produção de $\alpha$-CDs é notado também quando analisa-se a curva referente a produção de $\beta$-CDs (Figura 31). Perfis semelhantes ao longo do tempo são observados tanto para fécula e farelo quando analisados separadamente (Apêndice 6).

Após duas horas de reação houve tendência a estabelecer um patamar, tanto na hidrólise do amido quanto na produção de CDs e de extremidades redutoras, indicando perda considerável da atividade enzimática (Tabela 14). De acordo com RENDLEMAN (1992), a termoestabilidade desta CGTase é maior a 50\#C, temperatura esta que propicia $99 \%$ de atividade da enzima após 10 minutos de reação, enquanto durante o mesmo tempo de reação a $60 \#$ C apenas $93 \%$ de atividade da enzima é conservada. Admiti-se que apenas $3 \%$ da atividade da enzima é mantida pós 8 horas de reação a 60 \#C. Segundo FLASCHEL (1984), o aumento da temperatura promove aumento da atividade enzimática, mas também é responsável pelo aumento da velocidade de desativação e a $50^{\circ} \mathrm{C}$ a CGTase é estável durante 6 horas. A estabilidade térmica da enzima aumenta consideravelmente na presença de amido (FLASCHEL, 1984; 
NAKAMURA e HORIKOSHI, 1976; MÄKELÄ et al., 1990; FUJIWARA et al., 1992 b; KIM et al., 1993), o qual parece protege-la da desnaturação (KIM et al., 1993) e, quanto menor a concentração de substrato, mais cedo o patamar é atingido (FLASCHEL, 1984). Para concentração de $50 \mathrm{~g} / \mathrm{l}$ a estabilização ocorre após 4 horas de reação e para $300 \mathrm{~g} / \mathrm{l}$ após 10 horas de reação (FLASCHEL, 1984).Tais afirmações vão de encontro aos resultados obtidos, uma vez que a concentração de substrato usado foi equivalente a 50 g/l e a concentração de amido diminuiu consideravelmente após duas horas de reação (Figura 37). O aumento da concentração de CDs no meio também pode ter contribuído para a queda da atividade da CGTase; que segundo KIM et al. (1993) pode ser fortemente inibida pela presença de $\beta-C D s$.

A idéia de que ocorreu perda de atividade enzimática é reforçada quando se observa que não há degradação de CDs em dextrinas lineares (Figs. 31 e 36). Muitos autores afirmam que a CGTase degrada CDs (LEE e KIM, (1992); SAKAI et al. (1991); SATO et al., (1994)). A degradação de CDs pela CGTase é alvo de muitos estudos e vários autores afirmam que ela pode ser inibida através da adição de etanol (MATTSSON et al., (1991); LEE e KIM, (1992); KOBAYASHI e NAKASHIMA, (1991)). Segundo SAKAI et al. (1991), CDs são degradadas à oligossacarídeos quando a atividade enzimática da CGTase for muito alta para a concentração de substrato. Quando observa-se as Figuras 31 e 37, nota-se que apesar da concentração de amido apresentar queda considerável após duas horas de reação, não foi notada diminuição da concentração de $\alpha$ ou $\beta$-CDs. A correlação positiva significativa entre a quantidade de extremidades redutoras e CDs (Tabela 15) indica que, ocorreu aumento da concentração de CDs e de extremidades redutoras. No caso de haver degradação de CDs, tal correlação deveria ser negativa; ou seja, com a queda da concentração de CDs ocorreria aumento da concentração de extremidades redutoras, uma vez que as CDs estariam sendo convertidas em dextrinas lineares com extremidades redutoras. Tal resultado também indica que a quantidade de extremidades redutoras formada não foi suficiente para inibir a formação de CDs, uma vez que diversos trabalhos atribuem efeito de 
inibição da produção de CDs por maltose e glicose (BENDER, (1985); OKADA et al., (1994 b); RENDLEMAN, (1993)).

Outro resultado que revela a perda de atividade da CGTase é que não houve ação da enzima na conversão de $\alpha$-CDs em $\beta$-CDs. OKADA et al. (1994 a) afirmam que a reação de acoplamento é acompanhada pela conversão de $\alpha-C D$ em $\beta-C D$ e vice-versa. HAYASHIDA e KAWAKAMI (1992) observaram produção crescente de $\alpha$-CDs nas primeiras horas de reação, sendo que o decréscimo de $\alpha$-CDs foi acompanhado do aumento da concentração de $\beta$-CDs. Esses autores sugerem que há uma estreita relação entre o aumento da concentração de $\beta$-CDs e a diminuição de $\alpha$-CDs. Para BENDER, (1981 b) e MATTSSON et al. (1991), após longo período de incubação, a maioria de $\alpha$ CDs podem ser convertidas em $\beta$-CDs. FRENCH et al. (1954) e OKADA et al. (1994 a) notaram que a $\alpha$-CDs formadas na fase inicial da reação eram convertidas em $\beta$-CDs. RENDLEMAN (1992) relata que, com o passar do tempo de reação, a produção de $\beta$ CDs diminuiu e a de $\chi$-CDs aumentou, sugerindo que nas últimas horas de reação ocorre formação de $\chi$-CDs a partir de $\beta$-CDs. A correlação positiva significativa observada entre a produção de $\alpha$ e $\beta$-CDs (Tabela 15), reflete que não ocorreu queda da concentração de um tipo de CDs em função do aumento de outro, ou seja não houve conversão de $\alpha$-CD em $\beta$-CD nem conversão de $\beta$-CD em $\alpha-C D$.

O estudo da correlação entre as médias das quatro variáveis analisadas, através do coeficiente de Pearson, mostrou os resultados listados na Tabela 15.

Tabela 15. Estudo da correlação entre as médias das variáveis analisadas.

\begin{tabular}{cccc}
\hline & $\begin{array}{c}\text { Extremidade } \\
\text { redutora }\end{array}$ & $\alpha-\mathrm{CD}$ & $\beta-\mathrm{CD}$ \\
\hline Amido não hidrolisado & $(-)^{*}$ & $(-)^{*}$ & $(-)^{*}$ \\
Extremidade redutora & - & $(+)^{*}$ & $(+)^{*}$ \\
$\alpha-C D$ & - & - & $(+)^{*}$ \\
\hline
\end{tabular}

*: Diferença significativa a nível de $\alpha=5 \%$.

Através das correlações observadas na Tabela 15, pode-se afirmar que a produção de $\alpha-C D, \beta-C D$ e extremidades redutoras foram inversamente proporcionais à 
quantidade de amido não hidrolisado. A Tabela 15 indica ainda que houve correlação negativa significativa entre o amido não hidrolisado presente no meio e a produção de CDs; ou seja, a medida que aumentou a produção de CDs houve decréscimo da concentração de amido na reação. A correlação negativa significativa entre o amido não hidrolisado e a produção de CDs e entre o amido não hidrolisado e a produção de extremidades redutoras, indica a conversão do amido em cadeias de extremidades redutoras e ciclodextrinas.

Os resultados indicam que não houve diferença significativa entre quantidade de $\alpha$-CD produzida a partir de fécula e farelo de mandioca, mostrando assim que o farelo é uma matéria prima promissora para a produção de $\alpha$-CDs, em razão de sua disponibilidade e baixo custo. A viscosidade da suspensão de farelo exige uma temperatura maior de liquefação que à da fécula, além da etapa adicional de prensagem para extração do material líquido. $\mathrm{O}$ custo destas etapas de produção deve ser avaliado para que se possa quantificar a redução de custos da produção de CDs proporcionada pelo emprego do farelo como substrato. 


\section{CONCLUSÕES}

Os resultados obtidos permitem concluir que:

- a produção de CDs usando fécula e farelo como substrato é viável

- a enzima CGTase de Bacillus macerans da Amano International Enzyme Co. Inc. produz $\alpha$ e $\beta$-CD em proporções diferentes de acordo com a matéria prima empregada, sendo que, nas condições de ensaio, sua ação sobre o farelo possibilita maior produção de $\alpha$-CD que de $\beta$-CDs $(1,5: 1,0)$, ao passo que quando se emprega fécula como matéria prima a produção de $\beta$-CDs é favorecida $(1,0: 1,45)$

- uma vez que não houve diferença na produção de CDs quando o farelo é submetido à liquefação com $\alpha$-amilase, celulase ou CGTase, pode-se dizer que a liquefação do farelo com CGTase é vantajosa em relação à estas enzimas, pois reduz os custos de produção devido ao fato de trabalhar nas mesmas condições necessárias para produção de CDs

- nas condições de reação a $50^{\circ} \mathrm{C}$, tanto a hidrólise de amido quanto a produção de extremidades redutoras, $\alpha-C D$ e $\beta-C D$ atingem o pico em 2 horas de reação seguido da tendência à estabilização da curva ao longo do tempo, indicando queda da atividade enzimática após este período

- as correlações significativas entre as variáveis indicam que a quantidade de amido hidrolisado é inversamente proporcional ao grau de polimerização do amido e a produção de $\alpha$ e $\beta$-CDs. A produção de $\alpha-C D$ está correlacionada a de $\beta$-CD, e a produção de ambas CDs estão correlacionadas com a produção de açúcar redutor, indicando que a CGTase realiza simultaneamente tanto a reação de hidrólise quanto à reação de ciclização

- reação das amostras com $\beta$-amilase pode ser um auxiliar adequado para quantificação de $\alpha$-CDs em HPLC, nas condições de análise do ensaio, uma vez que o pico destas coincidem com o pico referente às dextrinas lineares de DP 6-7, visto que não degradou $\alpha$ e $\beta$-CDs

- o farelo é um substrato adequado quando a produção de $\alpha$-CDs é visada, enquanto que a fécula é um substrato que pode ser empregado tanto para a produção de 
$\alpha$-CDs como a de $\beta$-CDs. O farelo como substrato apresenta-se como alternativa promissora para redução de custos na produção de CDs, e uma interessante maneira de se aproveitar esse resíduo gerado pelas fecularias 


\section{REFERÊNCIAS BIBLIOGRÁFICAS}

ABE, S.; NAGAMINE, Y.; OMICHI, K.; IKENAKA, T. Investigation of the active site of Bacillus macerans cyclodextrin glucanotransferase by use of modified maltooligosaccharides. Journal of Biochemistry, Tokyo, 110:756-61, 1991.

ALFA LAVAL. Processo alfa laval de para amido de mandioca. 1972. 19 p.

ALVAREZ, H.; BERTOLINI, A. C.; CEREDA, M. P.; CHUZEL, G. Condiciones de analisis de las ciclodextrinas por HPLC. In: SEMINARIOS LATINOAMERICANOS Y DEL CIENCIA E TECNOLOGIA DE ALIMENTOS, 8, Montevideo, 1994. p.103. Montevideo, 1994.

ASSOCIATION OF OFFICIAL ANALYTICAL CHEMISTS. Official methodsof analysis. 13. ed. Washington, D.C., 1980. 109 p.

BANKS, W.; GREEWOOD, C. T.; KHAN, K. M. The interaction of linear, amylose oligomers with iodine. Carbohydrate Research, Amsterdan, 17: 25-33, 1971.

BANZATTO, D. A.; KRONKA, S. N. Experimentação Agrícola. Jaboticabal, FUNEP, 1989. 247p.

BENDER, H. A photometric assay for the initial rate of the cyclization reaction catalyzed by the cyclodextrin glycosyltransferase. Analytical Biochemistry, New York, 114: 158-62, 1981 a.

BENDER, H. Enzymology of the cyclodextrins. In: INTERNATIONAL SYMPOSIUM ON CYCLODEXTRINS, 1, Budapest, 1981 b. Annals. Budapest, 1981.

BENDER, H.; SIEBERT, R.; STADLER-SZÖKE, A. Can cyclodextrin glycosyltransferase be useful for the investigations of the fine structure of amylopectins?: characterization of the highly branched clusters isolated from digests with potato and maize starches. Carbohydrate Research, Amsterdan, 110:245-59, 1982.

BENDER, H. Effect of various acceptors on the rates of cyclization and chain-shortening of amylose catalyzed by the cyclomaltodextrin glycosyltransferase from Klebsiella pneumoniae M5 improvement of new photometric assay methods. Carbohydrate Research, Amsterdan 101:279-85, 1982. 
BENDER, H. Studies on the non-cyclics products of the cyclodextrin glycosyltransferase from Klebsiella pneumoniae M5 al. Starch/Stärke,Weinheim, 36 (2): 46-50, 1984.

BENDER, H. Studies of the inhibition by malto-oligosaccharides of the cyclisation reaction catalyzed by the cyclodextrin glycosyltransferase from Klebsiella pneumoniae M5 with glycogen. Carbohydrate Research, Amsterdan, 135:291-302, 1985.

BENDER, H. Purification and characterization of a cyclodextrin-degrading enzyme from Flavobacterium sp. Applied Microbiology and Biotechnology, Berlin, 39: 714-19, 1993.

BOOCOCK, G.; CAMILLERI, P. Beta-cyclodextrin inclusion complex of Mevinphos. Journal of Agricultural and Food Chemistry, London, 33(6):1032-4, 1985.

BRUMM, P. J.; HEBEDA, R. E.; TEAGUE, A. Purification and characterization of the commercialized, cloned Bacillus megaterium alfa-amylase. Part II: Transferase properties. Starch/Stärke,Weinheim, 43(8): 319-23, 1991.

CEREDA, M. P. Resíduos da industrialização da mandioca no Brasil. São Paulo, Ed. Paulicéia, 1994. 174 p.

CHATJIGAKIS, A. K.; CARDOT, J. P.; COLEMAN, A. W.; PARROT-LOEZ, H. Retention properties of cyclodextrins and modified cyclodextrins in reversed phase HPLC. Chromatographia, Oxford, 36: 174-8, 1993.

CHATJIGAKIS, A. K.; DONZÉ, C.; COLEMAN, A.W. Solubility behavior of betacyclodextrin in water/cosolvente mixtures. Analytical Chemistry, Washington, 64(14):1632-4, 1992.

CRAMER, F. e KAMPLE,W. Inclusion compounds. XVII Catalysis of decarboxilation by cyclodextrins. A model for mechanics. Journal of American Chemical Society, Easton, 87, p.1115-20, 1965.

CRÉMINON, C.; PILARD, F.; GRASSI, J.; PERLY, B.; PRADELLES, P. A sensitive and specific enzyme immunoassay for cyclomaltoheptaose and some derivates. Carbohydrate Research, Amsterdan, 258:179-86, 1994.

DAILEY, O.D. Preparation and characterization of cyclodextrin complexes of selected herbicides. In: FRIEDMAN, R.B. Biotechnology of amylodextrin oligosaccharides. Washington, ACS, 1991. p.317-30 
DELBOURG, M. F. Modulation de l'activitié de cyclodextrine glucoanotransferase en présence de polyétylène glycol. Compiegne, 1991. (Docteur - Universite de Technologie de Compiegne)

DE MOT, R.; VERACHTERT, H. Secretion of alfa-amylase and multiple forms of glucoamylase by the yeast Trichosporon pullulans. Canadian Journal of Microbiology, Ottawa, 32 (1):47-51, 1986.

DePINTO, J. A.; CAMPBELL, L. L. Pattern of action of the amylase and cyclodextrinase of Bacillus macerans. Archives of Biochemistry and Biophysics, New York, 125: 253-8, 1968 a.

DePINTO, J. A.; CAMPBELL, L . Purification and properties of the amylase of Bacillus macerans. Biochemistry, Washington, 7(1): 114-20, 1968 b.

DePINTO, J. A.; CAMPBELL, L. Purification and properties of the cyclodextrinase of Bacillus macerans. Biochemistry, Washington, 7(1): 121-5, $1968 \mathrm{c}$.

DRIOLI, E.; NATOLI, M.; KOTER, I.; TROTTA, F. An experimental study on a betacyclodextrin carbonate membrane reactor in PNPA hydrolysis. Biotechnology and Bioengineering, New York, 46(5): 415-20, 1995.

FLASCHEL, E.; LANDERT, J. P.; SPIESSER, D.; RENKEN, A. The production of alfa-cyclodextrin by enzymatic degradation of starch. Part II. Enzyme processes and processing steps of industrial interest. Annals of the New York Academy of Sciences, New York, 434: 70-7, 1984.

FRENCH, D.; LEVINE, M.; NORBERG, E.; NORDIN, P.; PAZUR, J. H.; WILD, G. $M$. Studies on the Schardinger dextrins. VII. Co-substrate specificity in coupling reactions of Macerans amylase. Journal of American Chemical Society, Easton, 76 (5):2387-90, 1954.

FRENCH, D. The Schardinger dextrins. Advanced in Carbohydrates Chemistry, New York, 12:189-260, 1957.

FRIEDMAN, R. B. Biotechnology of amylodextrin oligosaccharides. Washington, ACS, 1991. $341 \mathrm{p}$.

FUJWARA, S.; KAKIHARA, H.; SAKAGUCHI, K.; IMANAKA, T. Analysis of mutations in cyclodextrin glucanotransferase from Bacillus stearithermophilus which affect cyclization characteristics and termostability. Journal of Bacteriology, Baltimore, 174(22): 7478-81, 1992 a. 
FUJIWARA, S.; KAKIHARA, H.; WOO, K.B.; LEJEUNE, A.; KANEMOTO, M.; SAKAGUCHI, K.; IMANAKA, T. Cyclization characteristics of cyclodextrin glucanotransferase are conferred by the $\mathrm{NH}_{2}$-Terminal region of the enzyme. Applied and Environmental Microbiology, Washington, 52(12): 4016-25, 1992 b.

FUKUDA, K.; TERAMOTO, Y.; GOTO, M.; SAKAMOTO, J.; MITSUIKI, S.; HAYASHIDA, S. Specific inhibition by cyclodextrins of starch digestion by fungal glucoamylase. Bioscience, Biotechnology and Biochemistry, Tokyo, 56(4):556-9, 1992.

FUKUDA, M.; KUBOTA, Y.; IKUTA, A.; HASEGAWA,K.; KOIZIMI, K. Microanalyses of beta-cyclodextrin and glucosyl-beta-cyclodextrin in biological matrices by HPLC with pulsed amperometric detection. Analytical Biochemistry, New York, 212:289-91, 1993.

GALLIARD, T. Starch: properties and potential. Critical Reports on Applied Chemistry, Chichester, 13: 16-78, 1987.

GEORGANTA, G.; KANEKO, T.; KUDO, K.; HORIKOSHI, K. Expression of the CGTase gene of alkalophilic Bacillus N. 38-2 in various hosts. Starch/Starke,Weinheim, 43(9): 361-3, 1991.

GOTTVALDOVA, M.; HRABOVA, H.; SILLINGER, V.; KUCERA, J. Biospecific sorption of cyclodextrin glucosyltransferase on physically modified starch. Journal of Chromatography, Amsterdan, 427:331-8, 1988.

GRIFFON, D. Valorisation des produits, sous-produits et dechets de la petite et moyenne industrie de transformation du manioc en Amerique Latine. Montpellier: CIRAD, 1995. 1 v. (CEE/STD3 n.TS3-CT2-0110).

HASHIMOTO, K.; ADACHI, S.; SHIRAI, Y.; HORIE, M. Continuous separation of alfa-cyclodextrin and glucose using a simulated moving-bed adsorbed. Journal of Food Engineering, Amsterdan, 8: 187-200, 1988.

HAYASHIDA, K.; KAWAKAMI, K. Enhancement of enzymatic production of cyclodextrins by adding polyethylene glycol or polypropylene glycol. Journal of Fermentation and Bioengineering, Osaka, 73(3): 239-40, 1992.

HAYASHIDA, S.; TERAMOTO, Y.; INOUE, T. Production and characteristics of rawpotato-digesting alfa-amylase from Bacillus subtilis 65 . Applied and Environmental Microbiology, Washington, 54(6): 1516-22, 1988. 
HELLMAM, J.; WAHLBERG, M.; KARP, M.; KORPELA, T.; MÄNTSÄLÄ, P. Effects of modifications at the C-terminus of cyclomaltodextrin glucanotransferase from Bacillus circulans var. alkalophilus on catalytic activity. Biotechnology and Applied Biochemistry, Berlin, 12:387-96, 1990.

HODI, K; KATA, M.; SELMECZI, B.; DJURIC, Z. Morphological study of products containing $\beta$-Cyclodextrin. Starch/Starke,Weinheim, 43(5):186-90, 1991.

HORIKOSHI, K. Production and industrial applications of beta-cyclodextrin. Process Biochemistry, London, 14(5):26-30, 1979.

IMBERT, A. A revisit to the three-dimensional structure of B-type starch. Biopolymers, New York, 27 (8): 1205-21, 1988.

INSTITUTO ADOLFO LUTZ. Normas analíticas do Instituto Adolfo Lutz. Métodos químicos e físicos para análise em alimentos. 3 ed. São Paulo, 1985. v. 1, 126 p.

ITO, K.; HASUO, T.; MIYANO, N. Retention of the components aromatics in sake by cyclodextrin. Journal of the Brewing Society Japan, Tokyo, 83(3):201-4, 1988.

IVONY, K.; SZAJANI, B.; SERES, G. Immobilization of starch degrading enzymes. Journal of Applied Biochemistry, New York, 5: 158-64, 1983.

JEANG, C. H.; LIN, Y.W. Evidence for the presence of essential histidines on the cyclodextrin glucanotransferase from Bacillus macerans. Biotechnology and Applied Biochemistry, San Diego, 19:85-92, 1994.

KANEKO, T.; SONG, K. B.; HAMAMOTO, T.; KUDO, T.; HORIKOSHI, K. Construction of a chimeric series of Bacillus cyclomaltodextrin glucanotransferase and analysis of the thermal stabilities and $\mathrm{pH}$ optima of the enzymes. Journal of General Microbiology, London, 135: 3447-57, 1989.

KANEKO, T.; KUDO, T.; HORIKOSHI, K. Comparison of CD composition produced by chimeric CGTases. Agricultural and Biological Chemistry, Tokyo, 54(1), 197201,1990 a.

KANEKO, T.; NAKAMURA, N.; HORIKOSHI, K. Kinetic characterization of chimeric cyclomaltodextrin glucanotransferase from genes of two alkalophilic Bacillus. Starch/ Stärke, Weinheim, 42 (9):354-8, 1990 b.

KANEKO, T.; YOSHIDA, M.; YAMAMOTO, M.; NAKAMURA, N.; HORIKOSHI, $\mathrm{K}$. Production of cyclodextrins by simultaneous actions of two CGTases from three strains of Bacillus. Starch/Stärke, Weinheim, 42(7): 277-81, 1990 c. 
KIM, T.J.; LEE, Y.D.; KIM, H.S. Enzymatic production of cyclodextrins from milled com starch in an ultrafiltration membrane bioreactor. Biotechnology and Bioengineering, New York, 41(1):88-94, 1993.

KIMURA, K.; ISHII, Y.; YAMANE, K. Expression of the beta-cyclodextrin glucanotransferase gene of an alkalophilic Bacillus sp. \#1011 in Escherichia coli cells and characterization of the synthesized enzyme. Agricultural and Biological Chemistry, Tokyo, 54(3):641-8, 1990.

KIMURA, K.; KATAOKA, S.; NAKAMURA, A.; TAKANO, T.; KOBAYASHI, S.; YAMANE, $\mathrm{K}$. Functions of the COOH-terminal region of cyclodextrin glucanotransferase of alkalophilic Bacillus sp. \# 1011: Relation to catalyzing activity and $\mathrm{pH}$ stability. Biochemical and Biophysical Research Communications, New York, 161(3): 1273-9, 1989.

KIMURA, K.; TAKANO, T.; YAMANE, K. Molecular cloning of the beta-cyclodextrin synthetase gene from an alkalophilic Bacillus and its expression in Escherichia coli and Bacillus subtilis. Applied Microbiology and Biotechnology, Berlin, 26: 149-53, 1987.

KITAHATA, S.; HARA, K.; FUJITA, K.; NAKANO, H.; KUWAHARA, N.; KOIZUMI, K. Acceptor specificity of cyclodextrin glycosyltransferase from Bacillus stearothermophilus and synthesis of alfa-D-glucoyl O-beta-D-galactosyl (1-4)-betaD-glucoside. Bioscience, Biotechnology and Biochemistry, Tokyo, 56(9): 1386-91, 1992.

KITAHATA, S.; OKADA, S. Action of cyclodextrin glycosyltransferase form Bacillus megaterium strain n.5 on starch. Agricultural and Biological Chemistry, Tokyo, 38(12):2413-7, 1974.

KITAHATA, S.; OKADA, S.; FUKUI, T. Acceptor specificity of the transglycosylation catalyzed by cyclodextrin glycosyltransferase. Agricultural and Biological Chemistry Journal, Tokyo, 24 (12): 2369-74, 1978.

KLEIN, C.; HOLLENDER, J.; BENDER, H.; SCHULZ, G. E. Catalytic center of cyclodextrins glycosyltransferase derived from X-ray structure analysis combined with site-directed mutagenesis. Journal of American Chemical Society, Washington, 31(37):8740-6, 1992.

KOBAYASHI, S.; KAINUMA, K.; FRENCH, D. Effect of surfactantes on the ciclization of Bacillus macerans cyclodextrin glucanotransferase. Journal Japanese Society Starch Science, Tokyo, 30(1):62-8, 1983. 
KOBAYASHI, S.; NAKASHIMA, K. Action of cyclodextrin glucanotransferase on dimetil- and diglucosil-alfa-cyclodextrins. Journal of Carbohydrate Chemistry, New York, 10(4): 701-9, 1991.

KOIZUMI, K.; KUBOTA, Y.; OKADA, Y.; UTAMURA, T. Retention behavior of cyclodextrins on a reversed-phase columns in high-performance liquid chromatography. Journal of Chromatography, Amsterdan, 437:47-57, 1988.

KOIZUMI, K.; UTAMURA, T.; KUBOTA, Y. Two high-performance liquid chromatographic columns for analyses maltoligosaccharids. Journal of Chromatography, Amsterdan, 409: 396-403, 1987.

KOMIYA, T.; YAMADA, T.; IMAI, K.; HISAMATSU, M.; MASUI, H.; KAWAKISHI, S. Study on interactions of corn starch and gama-cyclodextrin with lipid peroxide. Starch/Stärke,Weinheim, 42 (10):394-7, 1990.

KONNO, A.; MIYAWAKI, M.; MISAKI, M; YASUMATSU, K. Bitterness reduction of fruits by beta-cyclodextrin. Agricultural and Biological Chemistry Journal, Tokyo, 45(10):2341-2, 1981.

LACH, J. L.; COHEN, J. Interation of pharmaceuticals with Schardinger dextrins II. Interation with selected compounds. Journal Pharmaceutical Science, Washington, 52(2):137-42, 1963.

LAAKSO, S.; LEIVO, P.; MÄKELÄ, M.; KORPELA, T. A polarographic cyclodextrin assay based on linoleate-cyclodextrin complex formation in a lipoxygenase reaction. Starch/Stärke, Weinheim, 36 (12):432-5, 1992.

LAEMMLI, U. K. Cleavage of structural proteins during the assembly of the head of bacteriophage T4. Nature, London, 227(15): 680-85, 1970.

LÁSZLÓ, E.; BÁNKY, B.; SERES, G.; SZEJTLI, J. Purification of cyclodextrin glycosyltransferase enzyme by affinity chromatography. Starch/Stärke, Weinheim, 33(8):281-3, 1981.

LEE, J. H.; CHOI, K. H.; CHOI, J. Y.; LEE, Y. S.; KWON, I. B.; YU, J. H. Enzymatic production of alfa-cyclodextrin with the cyclomaltodextrin glucanotransferase of Klebsiella oxytoca 19-1. Enzyme and Microbial Technology, Surrey, 14:1017-20, 1992. 
LEE, Y. D.; KIM, H. S. Effect of organic solvents on enzymatic production of cyclodextrins from unliquefied corn starch in an attrition bioreactor. Biotechnology and Bioengineering, New York, 39(10): 977-83, 1992.

LEJEUNE, A.; SAKAGUCHI, K.; IMANAKA, T. A spectrphotometric assay for the cyclization activity of cyclomaltohexaose (alfa-cyclodextrin) glucanotransferase. Analytical Biochemistry, New York, 181:6-11, 1989.

LINDER, K.; SZENTE, L.; SZEJTLI, J. Food flavouring with a-cyclodextrin complexed flavor substances. Acta Alimentaria, Budapest, 10 (3): 175-86, 1981.

LIU, G.; GOODALL, D. M.; LORAN, J. S. Quantification of trace levels of betacyclodextrin and substitution patterns in hydroxypropyl-beta-cyclodextrin using high performance liquid chromatography with a polarimetric detection. Chirality, New York, 5:220-3, 1993.

MacGREGOR, E. A. Relationships between structure and activity in the alfa-amylases family of starch-metabolising enzymes. Starch/Stärke,Weinheim, 45(7): 2327,1993 .

MAHMOUD, W.M; EL-SAYED, A.H.M.M.; COUGHLIN, R.W. Effect of $\beta$ cyclodextrin on production of L-phenylacetyl carbinol by immobilized cells of Saccharomyces cerevisae. Biotechnology and Bioengineering, New York, 36: 25662, 1990.

MÄKELÄ, M.; MATTSSON, P.; SCHININA, E.; KORPELA, T. Purification and properties off cyclodextrin glucanotransferase from an alkalophilic Bacillus. Biotechnology and Applied Biochemistry, San Diego, 10: 414-27, 1988.

MÄKELÄ, M.; PAAVILAINEN, S.; KORPELA, T. Growth dynamics of cyclodextrin glucanotransferase producing Bacillus circulans var. alkalophilus.Canadian Journal of Microbiology, Ottawa, 36:176-82, 1990.

MARSHALL, J. J., MIWA, I. Kinetic difference between hydrolysis of gamacyclodextrin by the human salivary and pancreatic amylases. Biochimica et Biophysica Acta, Amsterdan, 661(1): 142-7, 1981.

MATTSSON, P.; KORPELA, T.; PAAVILAINEN, S.; MÄKELÄ, M. Enhanced conversion of starch cyclodextrins in ethanolic solutions by Bacillus circulans var alkalophilus cyclomaltodextrin glucanotransferase. Applied Biochemistry and Biotechnology, Berlin, 30:17-28, 1991. 
METZGER, J. W.; JUNG, M.; SCHMALZING, D.; BAYER, E.; SCHURIG, V. Analysis of cyclomalto-oligosaccharides (cyclodextrins) and derivatives thereof by ion-spray mass spectrometry. Carbohydrate Research, Amsterdan, 222: 23-35, 1991.

NAKAMURA, A.; HAGA, K.; OGAWA, S.; KUWANO, K.; YAMANE, K. Functional relationships between cyclodextrin glucanotransferase from an alkalophilic Bacillus and alfa-amylases. Federation of European Biochemical Societies Letters, Amsterdan, 296(1):37-40, 1992.

NAKAMURA, A.; HAGA, K.; YAMANE, K. Three histidine residues in the active center of cyclodextrin glucanotransferase from Alkalophilic Bacillus sp. 1011: Effects of the replacement on $\mathrm{pH}$ dependence and transition state stabilization. Biochemistry, Washington, 32(36):6624-31, 1993.

NAKAMURA, A.; HAGA, K.; YAMANE, K. Four aromatic residues in the active center of cyclodextrin glucanotransferase from alkalophilic Bacillus sp. 1011: Effects of replacement on substratum binding and cyclization characteristics. Biochemistry, Washington, 33 (33):9929-36, 1994.

NAKAMURA, N.; HORIKOSHI, K. Production of Schardinger beta-dextrin by soluble and immobilized cyclodextrin glycosyltransferase of an alkalophilic Bacillus sp. Biotechnology and Bioengineering, New York, 19: 87-99, 1977.

NAKAMURA, N.; HORIKOSHI, K. Purification and properties of neutral-cyclodextrin glycosyltransferase of an alkalophilic Bacillus sp. Agricultural and Biological Chemistry,Tokyo, 40 (9): 1785-91, 1976.

NARDI, A.; FANALI, S.; FORET, F. Capillary zone electrophoretic separation of cyclodextrins with indirect UV photometric detection. Electrophoresis, Weinheim, 11: 74-6, 1990.

NELSON, N.A. Photometric adaptation of Somogy method for determination of glucose. Journal of Biological Chemistry, Baltimore, 153: 375-80, 1945.

NIELSEN, H.K. Novel bacteriolytic enzymes and cyclodextrin glycosyl transferase for the food industry. Food Technology, Chicago, January, 102-104, 1991.

NEMETHY, G.; SCHERAGA, H. A. Structure of water and hydrophobic bonding in proteins. II. Model for the thermodynamic properties of aqueous solutions hydrocarbons. Journal Chemical Physics, Lancaster, 36:3401-17, 1962. 
NIEMANN, C.; SAENGER, W. Enzymatic synthesis of low molecular weight amyloses with modified terminal groups. Carbohydrate Research, Amsterdan, 226: 119-30, 1992.

NOMOTO, M.; SHEW, D. C.; CHEN, S. J.; YEN, T. M.; LIAO, C. W.; YANG, C. P. Cyclodextrin glucanotransferase from alkalophilic bacteria of Tawan. Agricultural and Biological Chemistry, Tokyo, 48(5): 1337-8, 1984.

NOMOTO, M.; CHEN, C. C.; SHEU, D. C. Purification and characterization of cyclodextrin glucanotransferase from an alkalophilic bacterium of Taiwan. Agricultural and Biological Chemistry, Tokyo, 50 (11): 2701-07, 1986.

NORMAN, B.E.; JØRGENSEN, S.T. Thermoanaerobacter sp. CGTase: its properties and applications. Denpun Kagaku, Tokyo, 39 (2):101-108, 1992.

O'BOYLE. A.R.; ALADIM-KASSAM, N.; RUBIN, L.J.; DIOSADY, L.L. Encapsuled cured-meat pigment and its applications in nitrite-free ham. Journal of Food Science, Chicago, 57(4):807-12, 1992.

OGUMA, T.; KUKICHI, M.; MIZUAWA, K. Some culture conditions for the production of cyclodextrin-hydrolysing enzyme from Bacillus sphaericus. Agricultural and Biological Chemistry, Tokyo, 55 (6):1661-2, 1991.

OGUMA, T.; MATSUYAMA, A.; KIKUCHI, M,; NAKANO, E. Cloning and sequence analysis of the cyclomaltodextrinase from Bacillus sphaericus and expression in Escherichia coli cells. Applied Microbiology and Biotechnology, Berlin, 39: 197203, 1993 a.

OGUMA, T.; HORIUCHI, T.; KOKAYASHI, M. Novel cyclic dextrins, clycloisomaltooligosaccharides, from Bacillus sp. T-3040 culture. Bioscience, Biotechnology and Biochemistry, Tokyo, 57(7): 1225-7, 1993 b.

OHNISHI, M.; ABE, M.; TORU, A.; KUBOTA, M.; ROKUSHIKA, S. Tryptophan residues of Bacillus cycloamylose glucanotransferase: effect of modification with $\mathrm{N}$ bromosuccinimide on the enzyme catalyzed synthesis of cyclomaltoheptaoes from maltotriose. Starch/Stärke,Weinheim, 46 (7):272-5, 1994 a.

OHNISHI, M.; AZUMA, T.; KUBOTA, M. Cycloamylose glucanotransferase catalyzed cyclisation for a substrate maltose. Modification with N-bromosuccimide on the tryptophan residues. Starch/Stärke,Weinheim, 46 (7):276-9, 1994 b.

OHNISHI, M.; OTA, U.; ABE, M.; TONOMURA, B. Effect of modification of the tryptophan residues of cyclodextrin glucanotransferase with $\mathrm{N}$-bromosuccinimide on 
the enzyme-catalysed hydrolysis (cleavage) of soluble starch and cyclomaltohexose. Carbohydrate Research, Amsterdan, 227: 285-91, 1992.

OKADA, T.; ITO, M.; HIBINO, K. Immobilization of cyclodextrin glucanotransferase on capillary membrane. Journal of Fermentation and Bioengineering, Osaka, 77(3):259-63, 1994 a.

OKADA, T.; ITO, M.; HIBINO, K. Intermolecular transglycosylating reaction of cyclodextrin glucanotransferase immobilized on capillary membrane. Journal of Fermentation and Bioengineering, , Osaka, 77 (3): 264-7, 1994 b.

PARK, C. S.; PARK, K. H.; KIM, S. H. A rapid screening method for alkaline betacyclodextrin glucanotransferase using phenolphtalein-methyl-orange containing solid medium. Agricultural and Biological Chemistry, Tokyo, 53(4): 1167-9, 1989.

PIKRAMENOU, Z.; JOHNSON, K. M.; NOCERA, D.G. Synthesis of a cradle cyclodextrin. Chimie Recherche, 3531-4, 1993.

PODKOVYROV, S. M.; ZEIKUS, J. G. Structure of the gene encoding cyclomaltodextrinase from Clostridium thermohydrosulfuricum $39 \mathrm{E}$ and characterization of the enzyme purified from Escherichia coli. Journal of Bacteriology, Baltimore, 174(16): 5400-5, 1992.

PSZCZOLA, D. E. Production and potential food applications of cyclodextrins. Food Technology, Chicago, janeiro, 42:96-100, 1988.

RAJA, K.C.M.; RAMAKRISHNA, S.V. Improved reaction conditions for preparation off beta-cyclodextrin ( $\beta$-CD) form cassava (Manihot esculenta Crantz) starch. Starch/Starke, Weinheim, 46 (10):402-3, 1994.

RAJA, K. C. M.; SREEDHARAN, V. P.; PREMA, P.; RAMAKRISHNA, S. V. Cyclodextrin from cassava (Manihot esculenta Crantz) starch. Isolation and characterization as bromobenzene and chloroform chlathrates. Starch/Starke,Weinheim, 42 (5):196-8, 1990.

RAMAKRISHNA, S. V.; SASWATHI, N.; SHEELA, R.; JAMUNA, R. Evaluation of solid, slurry and submerged fermentations for the production of cyclodextrin glycosyltransferase by Bacillus cereus. Enzyme and Microbial Technology, Surrey, 16: 441-4, 1994.

RENDLEMAN Jr., J. A. Enhanced production of cyclomaltoocatoase (gamacyclodextrin) through selective complexation with $\mathrm{C} 12$ cyclic compounds. Carbohydrate Research, Amsterdan, 230: 343-59, 1992. 
RENDLEMAN Jr., J. A. Enhanced production of gama-cyclodextrin from corn syrup solids by means of cyclododecanona as selective complexant. Carbohydrate Research, Amsterdan, 247: 223-7, 1993.

RONG, D.; HONGPING, Y.; BOEHLOW, R.; D'SOUZA, V. T. Artificial redox enzymes. 1. Synthetic strategies. Journal Organic Chemistry, Baltimore, 57(1):163$7,1992$.

SABIONI, J. G. Produção e caracterização da ciclodextrina glicosiltransferase do Bacillus lentus alcalofilico. Campinas, 1991,(Doutorado - Faculdade de Engenharia de Alimentos/ UNICAMP).

SABIONI, J.G.; PARK, Y.K. Production and characterization of cyclodextrin glycosyltransferase from Bacillus lentus. Starch/Stärke, Weinheim, 44(6):225-9, 1992.

SAENGER, W. Cyclodextrin inclusion compounds in the research and industry. Angewandte Chemie International, edition, New York, 19(1): 344-62, 1980.

SAHA, B. C.; ZEIKUS, G. Characterization of the thermoestable cyclodextrinase form Clostridium thermohydrosulfuricum 39 E. Applied and Environmental Microbiology, Baltimore, 56(9): 2941-3, 1990.

SAHA, B.C.; ZEIKUS, G. Cyclodextrin degrading enzymes. Starch/Stärke, Weinheim, 44(8):312-5, 1992.

SAKAI, S.; YAMAMOTO, N.; YOSHIDA, S.; MUKUNI, K.; ISHIGAMI, H.; HARA, $\mathrm{K}$. Continuous production of glucosyl-cyclodextrins using immobilized cyclomaltodextrin glucanotransferase. Agricultural and Biological Chemistry, Tokyo, 55(1): 45-51, 1991.

SATO, M.; YAGI, Y.; NAGANO, H.; ISHIKURA, T. Determination of CGTase from Bacillus ohbensis and its optimum $\mathrm{pH}$ using HPLC. Agricultural and Biological Chemistry, Tokyo, 49(4): 1189-91, 1985.

SATO, M.; WATANABE, M.; NAGANO, H.; YAGI, Y. Selective degradation of beta and gama-cyclodextrin by co-digestion using a CGTase from Bacillus ohbensis and alfa-glucosydase for efficient alfa-cyclodextrin recovery. Biotechnology Letters, Kew, 16(7): 703-8, 1994. 
SAWADA, H.; SUZUKI, T.; AKIYAMA, S.; NAKAO, Y. Stimulatory effect of cyclodextrins of lankacidin-group antibiotics by Streptomyces species. Applied Microbiology and Biotechnology, Berlin, 26:522-6, 1987.

SCHLIMME, E. Removal of cholesterol from milk fat. European Dairy Magazine, 12/13(4):16-21, 1990.

SHIMADA, K.; KAWANO, K.; ISHII, J.; NAKAMURA, T. Structure of inclusion complexes of cyclodextrins with triglyceride at vegetable oil/water interface. Journal of Food Science, Chicago, 57(3):655-6, 1992.

SHIRAISHI, F.; KAWAKAMI, K; MARUSHIMA, H; FUKUOKA, F.F. Effect of ethanol on formation of cyclodextrin from soluble starch from Bacillus macerans cyclodextrin glycosiltransferase. Starch/Stärke, Weinheim, 41(4):151-55, 1989.

SIN, K. A.; NAKAMURA, A.; MASAKI, H; MATSSURA, Y.; UOZUMI, T. Replacement of an amino acid residue of cyclodextrin glucanotransferase of Bacillus ohbensis doubles the production of gama-cyclodextrin. Journal of Biotechnology, Baltimore, 32: 283-8, 1994.

SOMOGY, M. Determination of blood sugar. Journal Biological Chemistry, Baltimore, 160, 69-73, 1944.

SOPHIANOPOULUS, A. J.; WARNER, I. M. Purification of beta-cyclodextrin. Analytical Chemistry, Washington, 64(21): 2652-4, 1992.

STARNES, R. L. Industrial potential of cyclodextrin glycosyltransferase. Cereal Foods World, St. Paul, 35 (11):1094-9, 1990.

SU, C. S.; YANG, C. P. A novel method for continuous productions of cyclodextrin using an immobilized enzyme system. Journal of Chemical Technology and Biotechnology, London, 48: 313-23, 1990.

SUZUKI, Y.; IMAI, T. Bacillus stearothermophilus KP 1064 pullulan hydrolase. Applied Microbiology and Biotechnology, Berlin, 21(1/2): 20-6, 1985.

SUZUKI, M; SATO, A. Nutritional significance of cyclodextrins: indigestibility and hipolemic effect of alfa-cyclodextrin. Journal Nutritional Science and Vitaminology, Osaka, 31(2): 209 -23, 1985.

SZEJTLI, J.; FENIVESI, E.; ZSANDON, B. Cyclodextrinpolymere. Starch/Stärke, 30 (4): 127-31, 1978. 
SZEJTLI, J. Enhancement of drug bioavailabilty by cyclodextrins. Starch/Stärke,Weinheim, 33(11): 387-90, 1981.

SZEJTLI, J. Cyclodextrins in food, cosmetic and toiletries. Starch/Stärke, Weinheim, 34(11): 379-85, 1982.

SZEJTLI, J. Physiological effects of cyclodextrins on plants. Starch/Stärke, Weinheim, 35(12):433-8, 1983.

SZEJTLI, J. Highly soluble beta-cyclodextrin derivates. Starch/Stärke, Weinheim, 36 (12):429-32, 1984.

SZEJTLI, J. The cyclodextrins and their applications in biotechnology. Carbohydrate Polymers, Barking, 12:375-92, 1990.

SZEJTLI, J. The properties and potential uses of cyclodextrins derivatives. Journal of Inclusion Phenomena and Molecular Recognition in Chemistry, Dordrecht, 14:25-36, 1992.

SZEJTLI, J; OLAH, B. Molecular encapsulation of pesticides by the use of cyclodextrins. Review of Applied Entomology. Série A, London, 1983.

SZEJTLI, J.; SEBESTYÉN, G. Resorption, metabolism and toxicity studies on the peroral application of beta-cyclodextrin. Starch/Stärke, Weinheim, 31:385-9, 1979.

SZENTE, L; SZEJTLI, J. Molecular encapsulation of natural and synthetic coffee flavor with beta-cyclodextrin. Journal of Food Science, Chicago, 51(4):1024-27, 1986.

SZENTE, L; GAL-FUZY, M.; SZEJTLI, J. The aromatization with beta-cyclodextrin complexed flavors. Acta Alimentaria, Budapest, 17(2):193-9, 1988.

TABUSHI, I.; KIYOSUKE, Y.; SUGIMOTO, T.; YAKAMAMURA, K. Approach to he aspects of driving force of inclusion by d-cyclodextrin. Journal of American Chemical Society, Easton, 100:916-9, 1978.

TAKEGUCHI, T.; MIWA, T. Liquid chromatography of cyclodextrins with indirect photometric detection of phenolphthalein inclusion complexes. Chromatographia, New York, 38(7/8): 453-5, 1994.

THAKKAR, A. L.; KUEHN, P. B.; PERRIN, J. H.; WILHAN, W. L. Cycloheptaamylose-barbiturate inclusion complexes: solubility and circular dichroism studies. Journal of Pharmaceutical Science, Washington, 61(11):1841-3, 1972. 
TILDEN, E.B.; HUDSON, C.S. Conversion of starch to crystalline dextrins by the action of a new amylase separate from culture of Bacillus macerans. Journal of American Chemical Society, Easton, 61;2900-2, 1939.

TREDER, W.; ZEHAVI, U.; THIEM, J.; HERCHMAN, M. Disproportionation by immobilized cyclodextrin alfa-1-4 glucosyltransferase reaction with soluble polymeric acceptors. Biotechnology and Applied Biochemistry, San Diego, 11: 362-6, 1989.

TSUCHIYAMA, Y.; YAMAMOTO, K.; ASOU, T.; OKABE, M.; YAGI, Y.; OKAMOTO, R. A novel process of cyclodextrin production by the use of specific adsobents: Part I. Screening of specific adsorbents. Journal of Fermentation and Bioengineering, Osaka, 71(6): 407-12, 1991 a.

TSUCHIYAMA, Y.; NOMURA, H.; OKABE, M.; OKAMOTO, R. A novel process of cyclodextrin production by the use of specific adsobents: Part II. A new reactor system for selective production of alfa-cyclodextrin with specific adsorbent. Journal of Fermentation and Bioengineering, Osaka, 71(6): 413-7, $1991 \mathrm{~b}$.

VAN BEYNUM, G. M. A.; ROELS, J. A. Starch conversion technology. New York, Marcel Dekker, 1985. 362 p.

VETTER, D.; THORN, W. Chain length specificity of cyclodextrin glycosyltransferase. Starch/Stärke, Weinheim, 44(6):229-33, 1992 a.

VETTER, D.; THORN, W. Directed enzymes synthesis of linear and branched glucoamilosaccharides, using cyclodextrin-glucanosyltransferase. Carbohydrate Research, Amsterdan, 223: 61-9, 1992 b.

VILPOUX, O.; CEREDA, M .P. Caracterização das fecularias no Brasil. In: CERAT. Relatório do programa da Comunidade Européia: "Valorização dos produtos e subprodutos da mandioca". Botucatu, 1995. 71 p. (CERAT, std.3).

WIEDENHOF, N. Properties of cyclodextrin. Part IV. Featuresand use of insoluble cyclodextrins-epichlorihydrin-resins. Starch/Starke, Weinhein, 21:119-23, 1969.

WHITE, G.; KATONA, T.; ZODDA, J.P.; EAKINS, M.N. Determination of the impurity profile of gama-cyclodextrin by high-performance liquid chromatography. Journal of Chromatography, Amsterdan, 624:157-61, 1992.

WOSIACKI, G.; CEREDA, M. P.; SARMENTO, S. B. S.; ABBUD, N. S. The cassava (Manihot esculenta) c.v. Pioneira. Characteristics of the starch fraction. Agricultural and Biological Technology, 33(2): 255-64, 1900. 
WURZBURG, O. B. Modified starches: properties and uses. Boca Raton, CRC Press, 1987. $277 \mathrm{p}$.

YAMAMOTO, M.; HORIKOSHI, K. Isolation and purification of alpha-cyclodextrin by synthetic adsorption polymer. Starch/Sträke, Weinheim, 33 (7): 244-6, 1981.

YANG, C. P.; SU, C. S. Study of cyclodextrin production using cyclodextrin glycosyltransferase immobilized on chitosan. Journal Chemical Technology Biotechnology, London, 46: 283-94, 1989.

YE, H.; RONG, D.; D'SOUZA. Eletrophilic catalysis by cyclodextrins. Chimie Recherche 5231-34, 1991.

YU, E.K.C.; AOKI, H.; MISAWA, M. Specific alpha-cyclodextrin production by a novel thermostable cyclodextrin glycosyltransferase. Applied Microbiology and Biotechnology, Berlin, 28: 377-9, 1988.

ZEHAVI, U.; HERCHMAN, M.; THIEM, J. Polymeric acceptors in alfa-1,4 glucosyltransferase reactions involving free and immobilized cyclodextrin alfa-1,4 glucosyltransferase. Biotechnology and Applied Biochemistry, San Diego, 15 :217-20, 1992.

ZSADON, B.; OTTA, K. H.; TÜDÖS, F.; SZJETLI, J. Separation of cyclodextrins by high performance chromatography. Journal of Chromatography, Amsterdan, 172: 490-2, 1979. 
APÊNDICE 1.Curva padrão para quantificação de $\alpha$-CDs, obtida através das áreas dos picos dos cromatogramas.

\section{Curva padrão de $\alpha-C D s$}

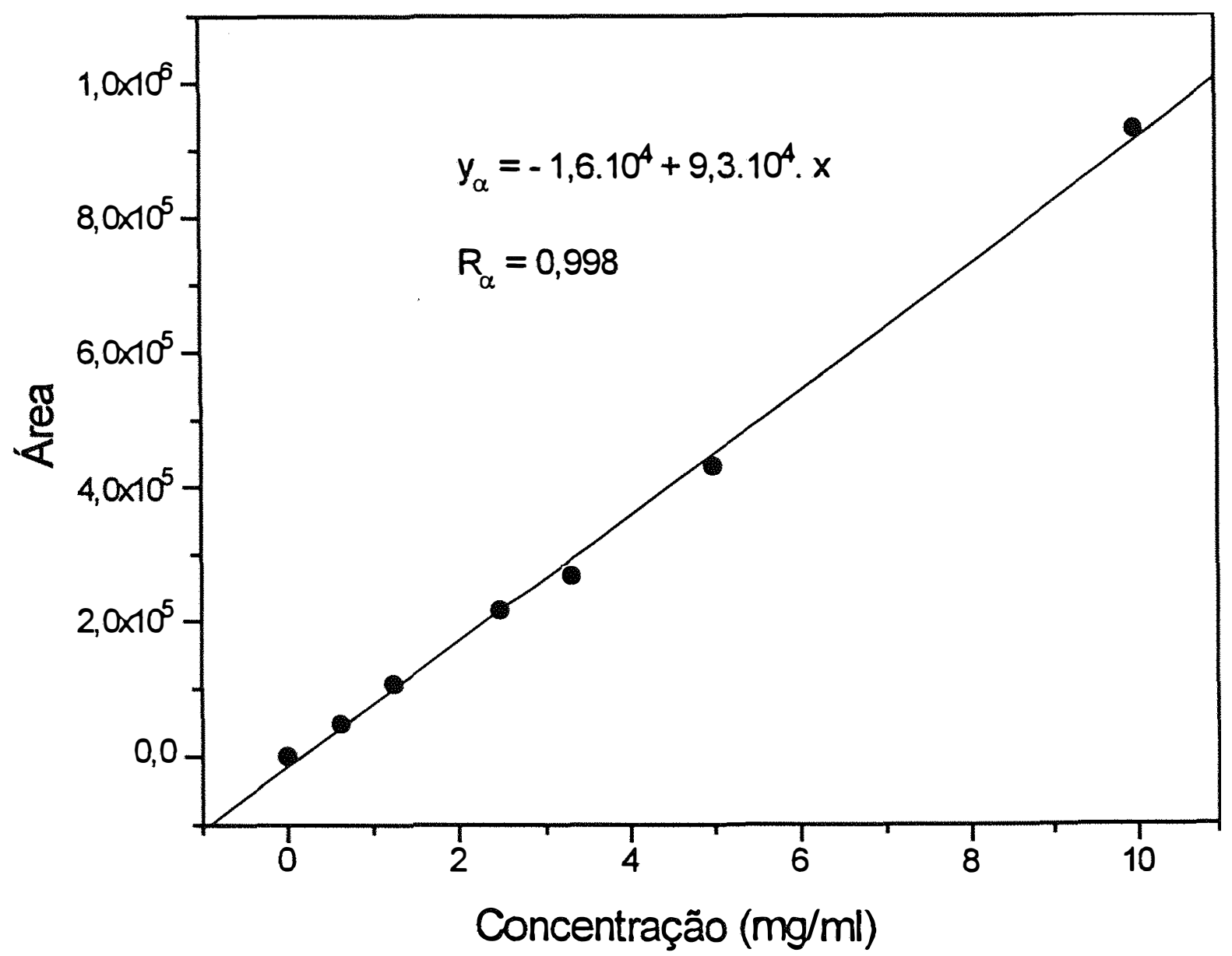


APÊNDICE 2.Curva padrão para quantificação de $\beta$-CDs, obtida através das áreas dos picos dos cromatogramas.

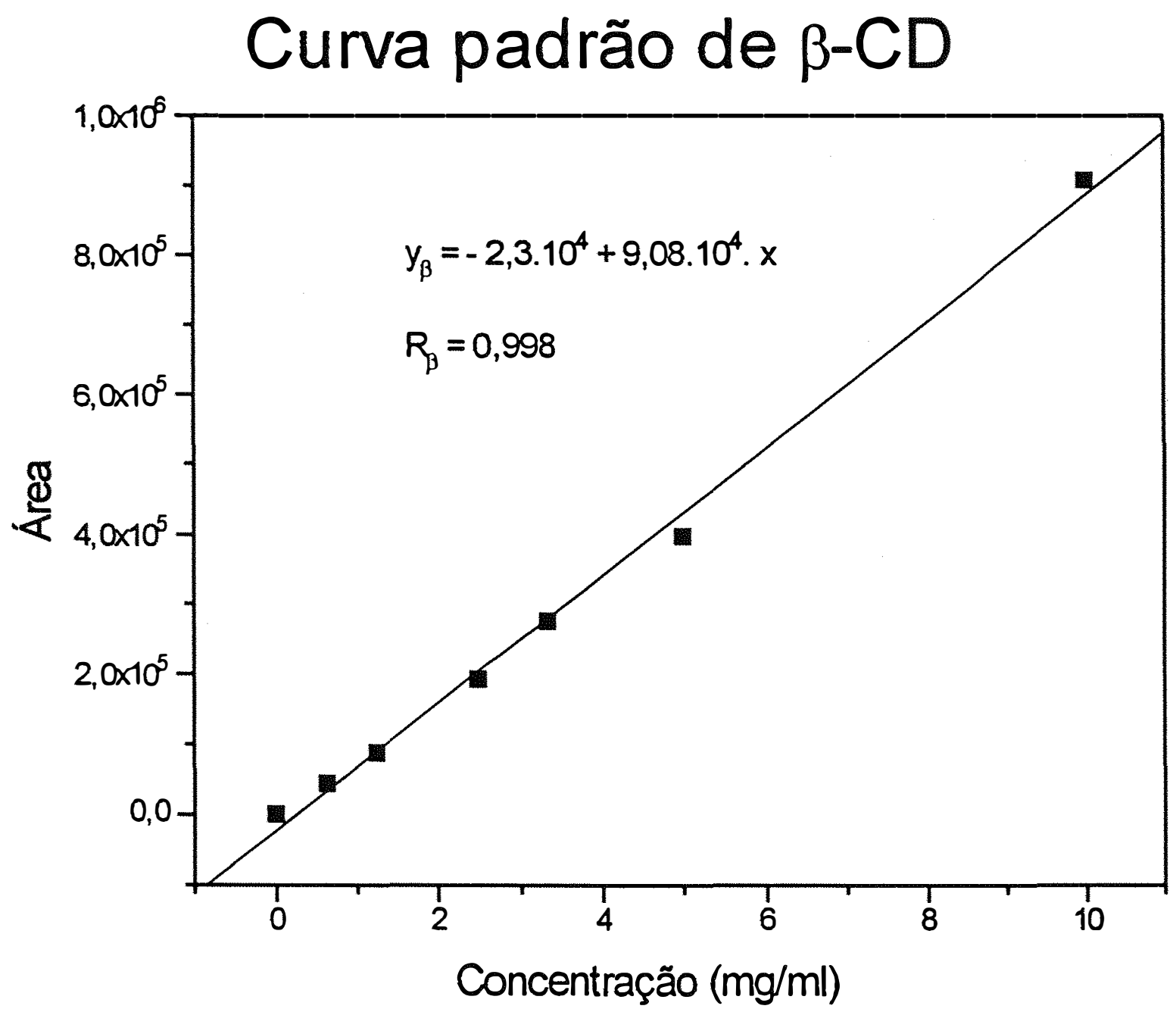


APÊNDICE 3.Curva padrão para quantificação de $\gamma$-CDs, obtida através das áreas dos picos dos cromatogramas.

\section{Curva padrão de $\chi$-CDs}

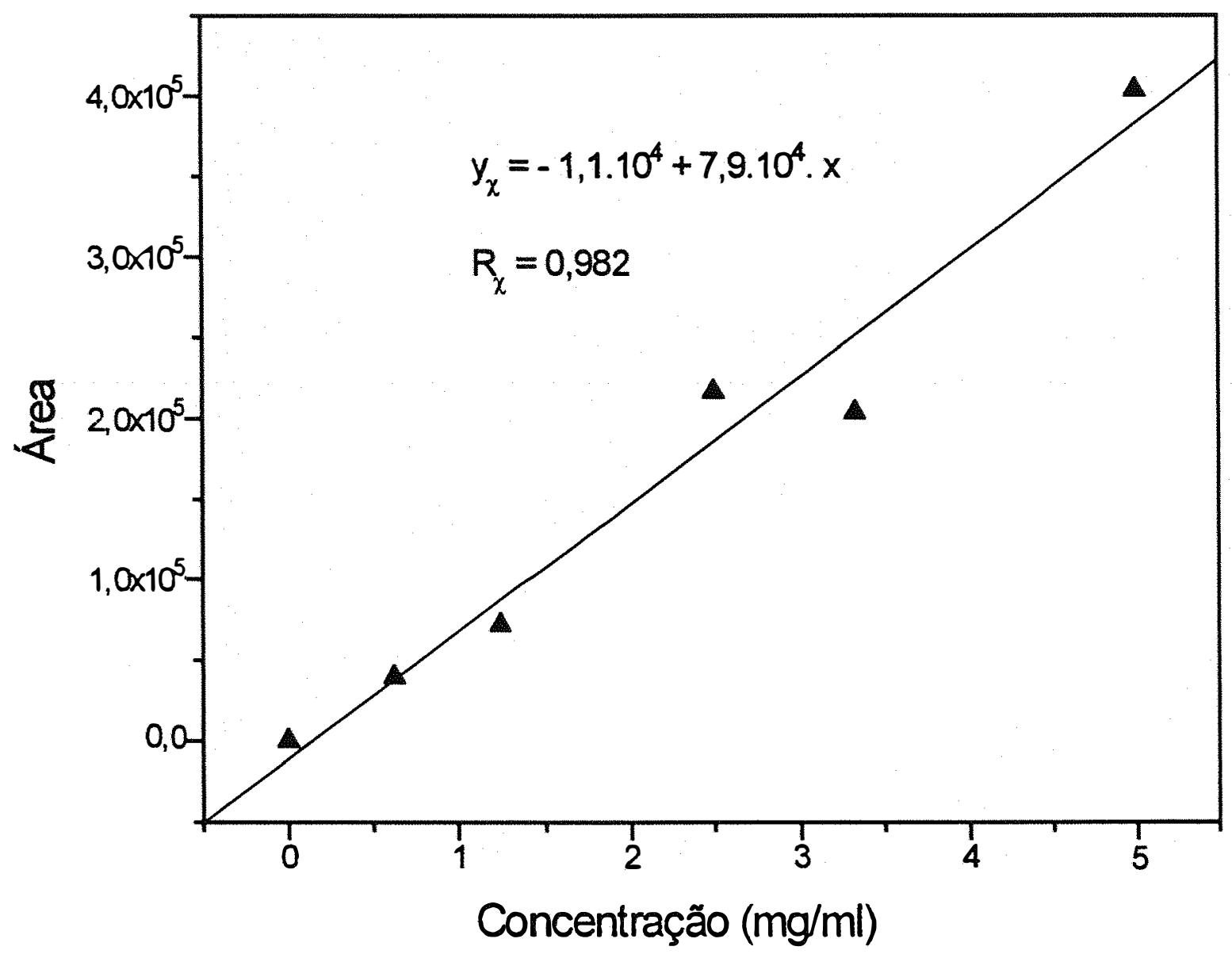


APÊNDICE 4.Curva padrão para quantificação de amido solúvel, com leitura espectrofotométrica feita a $620 \mathrm{~nm}$.

\section{Curva padrão de amido}

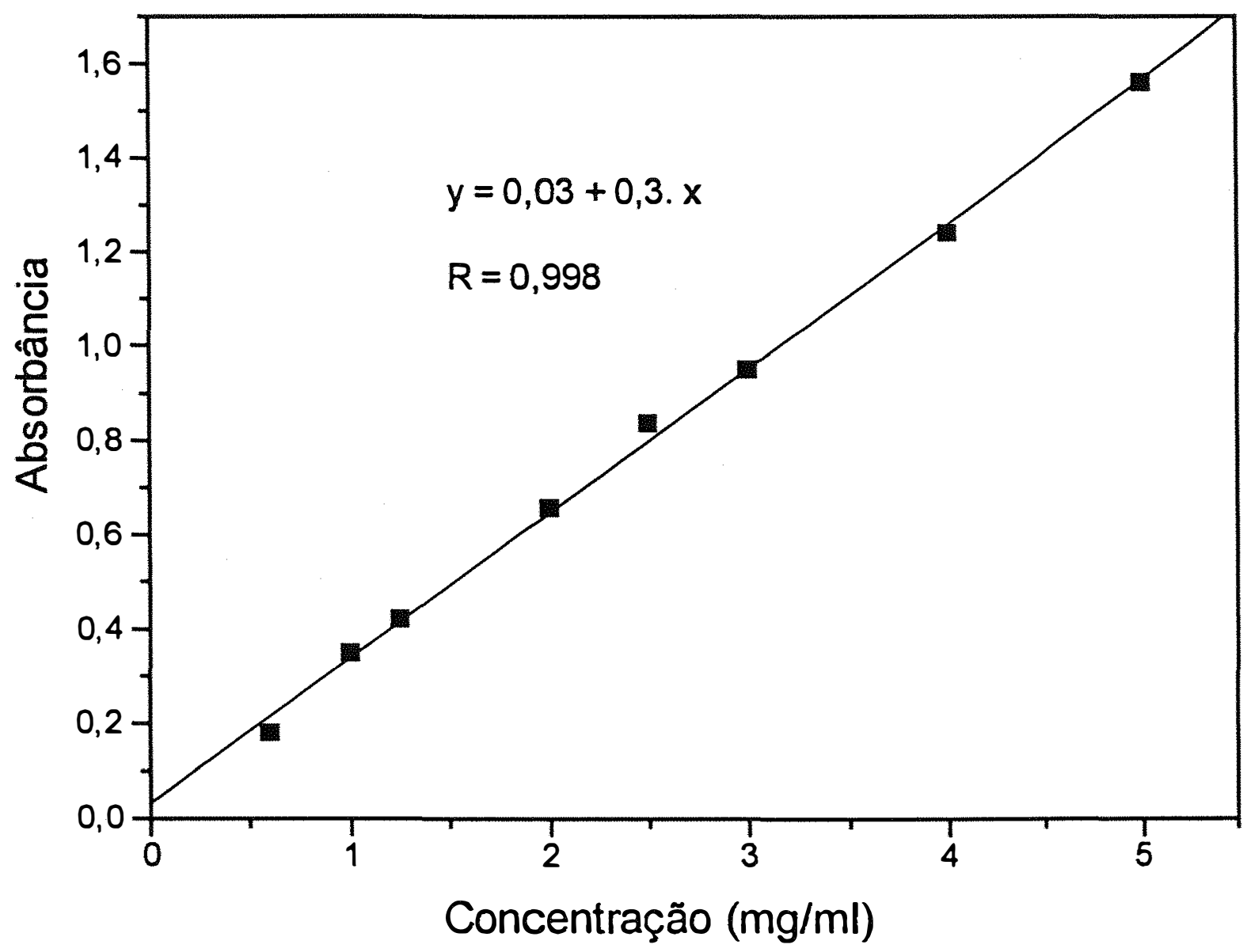


APÊNDICE 5.Curva padrão para quantificação de extremidades redutoras com leitura espectrofotométrica feita a $535 \mathrm{~nm}$.

\section{Curva padrão de glucose}

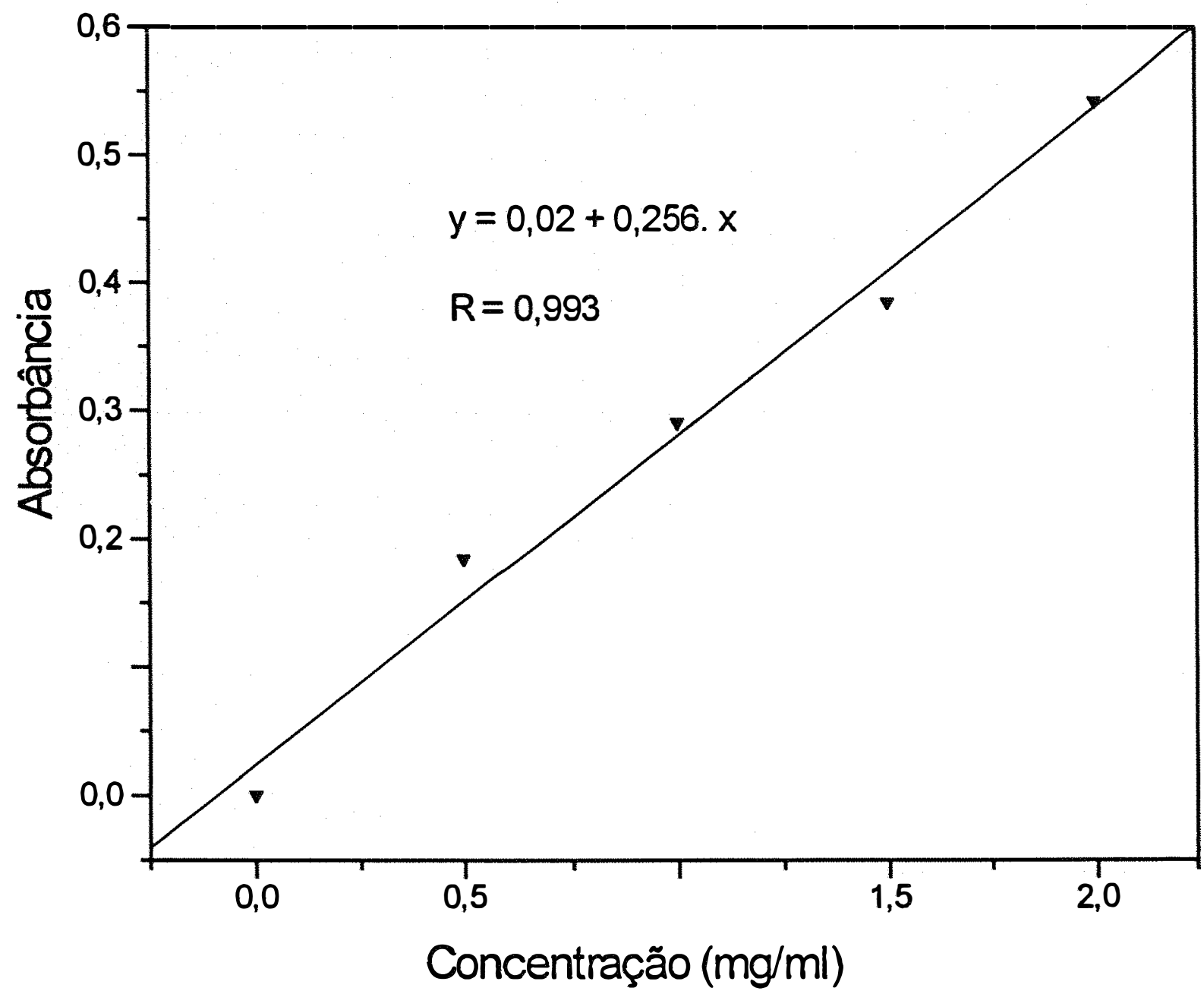




\section{APENNDICE 6.}

Análise estatística para as médias das repetições de extremidades redutoras e amido não hidrolisado ao longo da reação para fécula e farelo. Comparação entre os diferentes tempos de reação.

\begin{tabular}{|c|c|c|c|c|}
\hline \multirow[b]{2}{*}{$\begin{array}{l}\text { Tempo } \\
\text { (horas) }\end{array}$} & \multicolumn{2}{|c|}{$\begin{array}{l}\text { Extremidades redutoras } \\
(\mathrm{mg} / \mathrm{ml})\end{array}$} & \multicolumn{2}{|c|}{ Amido $(\mathrm{mg} / \mathrm{ml})$} \\
\hline & $\begin{array}{c}\text { Fécula } \\
\text { DMS }=0,50\end{array}$ & $\begin{array}{c}\text { Farelo } \\
\text { DMS }=0,77\end{array}$ & $\begin{array}{c}\text { Fécula } \\
\text { DMS }=3,98\end{array}$ & $\begin{array}{c}\text { Farelo } \\
\text { DMS }=1,77\end{array}$ \\
\hline Liquefação & $0,82^{c}$ & $1,17 \mathrm{~b}$ & $5,14^{a}$ & $5,29 \mathrm{a}$ \\
\hline 2 & $1,95 \mathrm{~b}$ & $1,93 \mathrm{ab}$ & $0,27 \mathrm{~b}$ & $0,22 \mathrm{~b}$ \\
\hline 4 & $2,30 \mathrm{ab}$ & $2,18^{a}$ & $0,22 \mathrm{~b}$ & $0,39 \mathrm{~b}$ \\
\hline 6 & $2,46^{a}$ & $2,38 \mathrm{a}$ & $0,21 \mathrm{~b}$ & $0,28 \mathrm{~b}$ \\
\hline 8 & $2,40 \mathrm{ab}$ & $1,92 \mathrm{ab}$ & $0,14^{b}$ & $0,49 \mathrm{~b}$ \\
\hline 10 & $2,52^{a}$ & $1,87 \mathrm{ab}$ & $0,14^{b}$ & $0,44 \mathrm{~b}$ \\
\hline 12 & $2,60^{a}$ & $2,12 \mathrm{a}$ & $0,12 \mathrm{~b}$ & $0,55 \mathrm{~b}$ \\
\hline 22 & $2,47 \mathrm{a}$ & $2,55^{a}$ & $0,10 \mathrm{~b}$ & $0,38 \mathrm{~b}$ \\
\hline 24 & $2,29 \mathrm{ab}$ & $2,20^{a}$ & $0,08 \mathrm{~b}$ & $0,58 \mathrm{~b}$ \\
\hline
\end{tabular}

* Valores com letras diferentes nas colunas diferem significativamente para o Teste de Tuckey ao nível de $\alpha=0.05$.

Análise estatística para as médias das repetições de $\alpha$-CDs e $\beta$-CDs ao longo da reação para fécula e farelo. Comparação entre os diferentes tempos de reação.

\begin{tabular}{ccccc}
\hline \multirow{2}{*}{ Tempo } & \multicolumn{2}{c}{$\alpha$-CDs $(\mathrm{mg} / \mathrm{ml})$} & \multicolumn{2}{c}{$\beta$-CDs $(\mathrm{mg} / \mathrm{ml})$} \\
\cline { 2 - 5 } & $\begin{array}{c}\text { Fécula } \\
\text { DMS }=0,54\end{array}$ & $\begin{array}{c}\text { Farelo } \\
\text { DMS }=0,47\end{array}$ & $\begin{array}{c}\text { Fécula } \\
\text { DMS }=5,13\end{array}$ & $\begin{array}{c}\text { Farelo } \\
\text { DMS }=2,30\end{array}$ \\
\hline Liquefação & $7,67^{\mathrm{a}}$ & $3,87^{\mathrm{b}}$ & $6,37^{\mathrm{b}}$ & $0,80^{\mathrm{b}}$ \\
2 & $10,97^{\mathrm{a}}$ & $8,81^{\mathrm{a}}$ & $12,53 \mathrm{a}$ & $4,68 \mathrm{a}$ \\
4 & $8,93^{\mathrm{a}}$ & $8,44^{\mathrm{a}}$ & $12,99 \mathrm{a}$ & $5,42 \mathrm{a}$ \\
6 & $10,03 \mathrm{a}$ & $8,37 \mathrm{a}$ & $13,36^{\mathrm{a}}$ & $5,76^{\mathrm{a}}$ \\
8 & $8,34^{\mathrm{a}}$ & $8,59 \mathrm{a}$ & $12,64 \mathrm{a}$ & $6,53 \mathrm{a}$ \\
10 & $8,89 \mathrm{a}$ & $8,70^{\mathrm{a}}$ & $14,15^{\mathrm{a}}$ & $6,26^{\mathrm{a}}$ \\
12 & $9,54 \mathrm{a}$ & $8,21 \mathrm{a}$ & $14,64 \mathrm{a}$ & $6,28 \mathrm{a}$ \\
22 & $9,96^{\mathrm{a}}$ & $8,53 \mathrm{a}$ & $17,01 \mathrm{a}$ & $6,65^{\mathrm{a}}$ \\
24 & $11,04^{\mathrm{a}}$ & $8,74^{\mathrm{a}}$ & $17,22 \mathrm{a}$ & $6,26^{\mathrm{a}}$ \\
\hline
\end{tabular}

* Valores com letras diferentes nas colunas diferem significativamente para o Teste de Tuckey ao nível de $\alpha=0.05$. 